\title{
ESTRUTURAS TIPO SANDUÍCHE COM \\ PLACAS DE ARGAMASSA PROJETADA
}

\author{
Alexandre Araújo Bertini
}

Tese apresentada à Escola de Engenharia de São Carlos, como parte dos requisitos para obtenção do título de Doutor em Engenharia de Estruturas

ORIENTADOR: Prof. Dr. Libânio Miranda Pinheiro 
Aos meus pais e irmãos, à Mirian à Bruna, e à pequenina Gabriele. 


\section{AGRADECIMENTOS}

A Deus em primeiro lugar que permitiu que eu chegasse até o fim deste trabalho. Agradeço também a minha família que soube compreender pacientemente todo este tempo que me dediquei ao doutorado.

Ao Professor João Bento de Hanai pela idéia inicial do trabalho e pela orientação durante grande parte do trabalho.

Ao Professor Libânio Miranda Pinheiro pela orientação no momento final do trabalho, pelo apoio, pela amizade, pela compreensão, pelo empenho, pela paciência e dedicação, o meu muito obrigado.

Aos Professores Toshaki Takeia e José Samuel Giongo pelas valiosas sugestões e pela prontidão com que eu era recebido sempre que os procurava.

Ao Dr. Luiz Vareda e aos técnicos: Amaury, Mauri, Jorge, Mário, Valdir, João e Ricardo pelo empenho e dedicação nos trabalhos de laboratório.

Aos funcionários Rosi, Marta, Toninho, Júnior, Silvia, Chico, Massaki e Nadir, que facilitaram meu trabalho durante todo este tempo.

Aos amigos Magid, Jorginho e Pedro pela amizade firmada e por terem sido apoio em momentos difíceis.

Aos Diretores do Instituto Centro de Ensino Tecnológico (CENTEC) Prof. Antônio Amaury Oriá Fernandes, Prof ${ }^{\mathrm{a}}$. Elda Fontineli Tahim e Prof. Carlos Humberto Souza Andrade, pelo incentivo dado.

Ao Prof. Francisco Carvalho de Arruda Coelho, da Universidade Estadual Vale do Acaraú, pelo apoio fornecido.

Aos Engenheiros Yuki e Danilo, diretores da empresa Código Engenharia, pelo fornecimento dos painéis de EPS para realização dos ensaios.

A Fundação de Amparo à Pesquisa do Estado de São Paulo - FAPESP - e ao Conselho Nacional de Desenvolvimento Científico e Tecnológico - CNPq - pelo apoio financeiro. 


\section{SUMÁRIO}

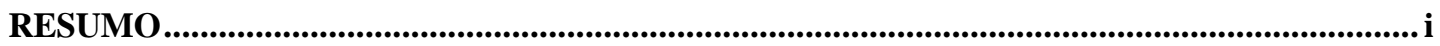

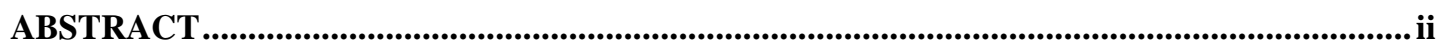

LISTA DE FIGURAS ..........................................................................................................

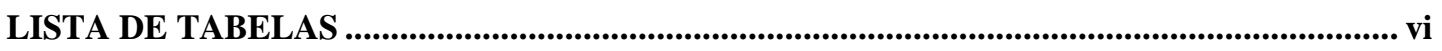

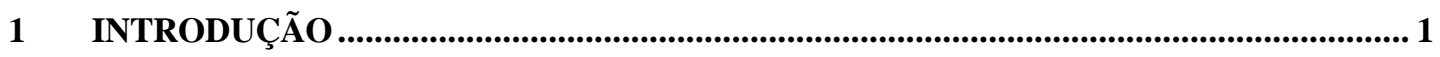

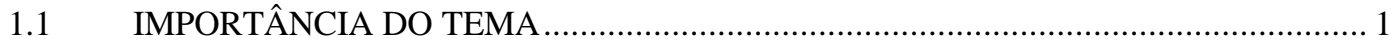

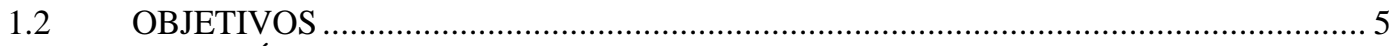

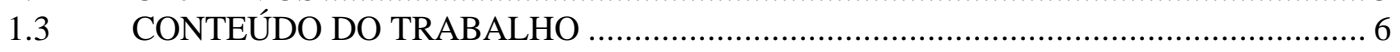

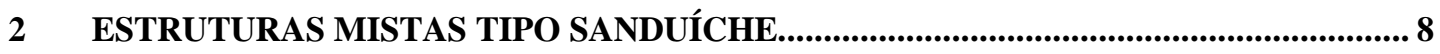

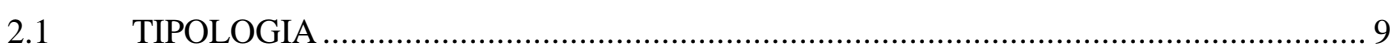

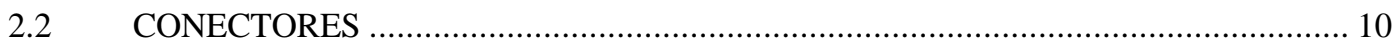

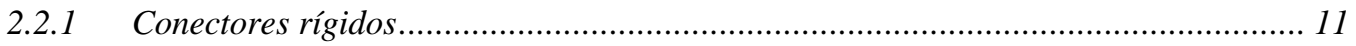

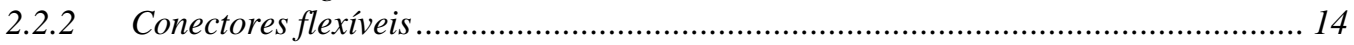

2.2.3 Recomendações sobre os conectores ................................................................... 15

2.3 MÉTODO CONSTRUTIVO COM FACES MOLDADAS NO LOCAL ......................... 17

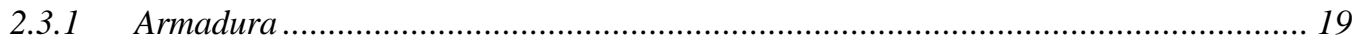

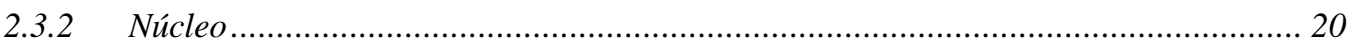

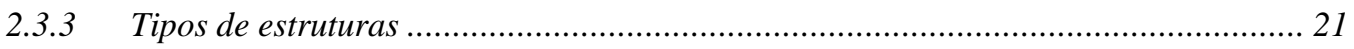

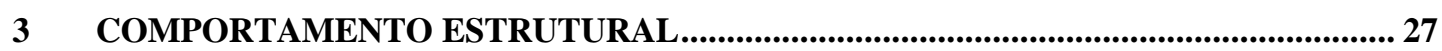

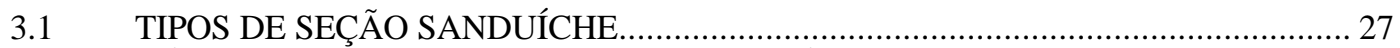

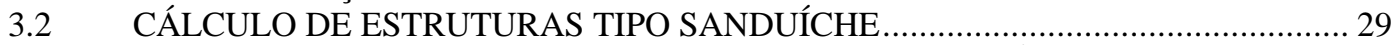

3.3 ENSAIOS REALIZADOS EM ESTRUTURAS TIPO SANDUÍCHE ............................ 34

3.3.1 Ensaios realizados por BANSUNBUL et al (1991)....................................................... 34

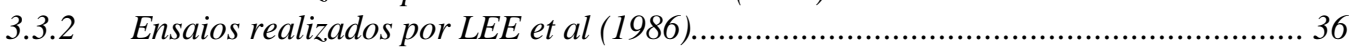

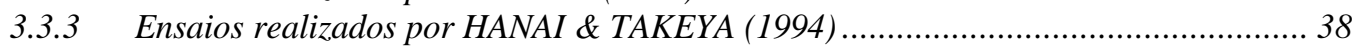

3.3.4 Ensaios realizados por BUSH \& STINE (1994)..................................................... 40

3.3.5 Ensaios realizados por por PFEIFER \& HANSON (1965)..................................... 43

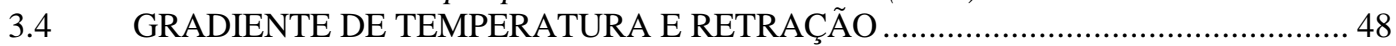

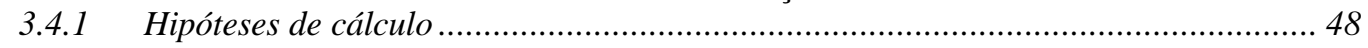

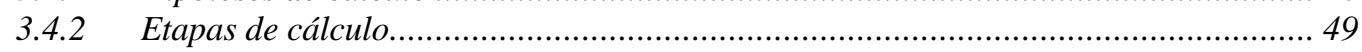


4 ARGAMASSA E MICROCONCRETO PROJETADOS..................................................52

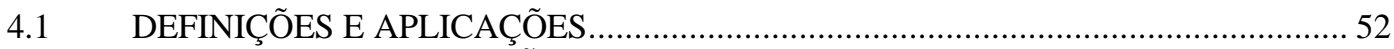

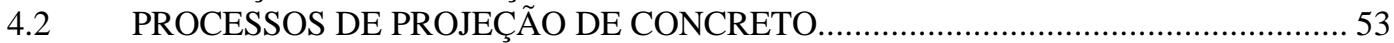

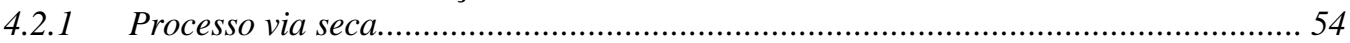

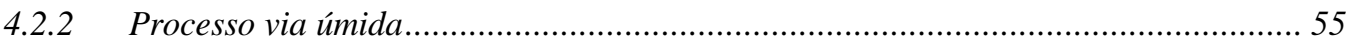

4.3 CONCEITOS SOBRE ARGAMASSA E MICROCONCRETO ……........................... 55

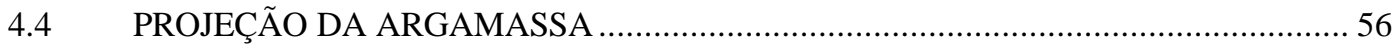

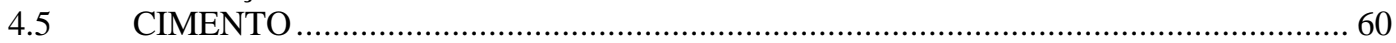

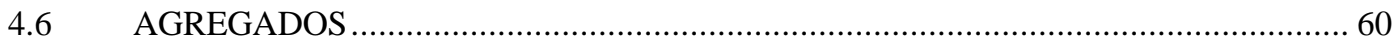

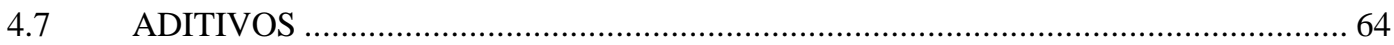

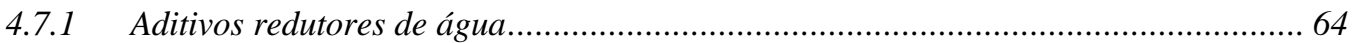

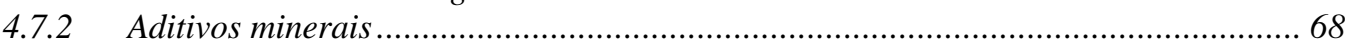

4.8 SOBRE A DOSAGEM DE CONCRETOS E ARGAMASSAS ……........................... 70

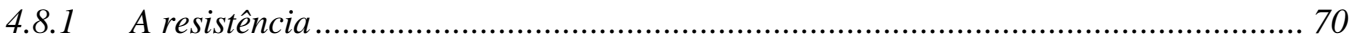

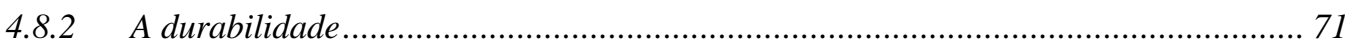

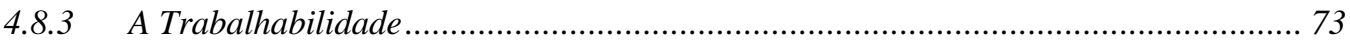

4.9 PROCEDIMENTOS PARA EFETUAR UMA DOSAGEM ……............................... 74

5 RESISTÊNCIA EFETIVA DA ARGAMASSA PROJETADA …........................................... 77

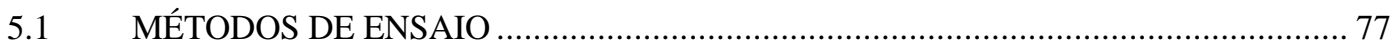

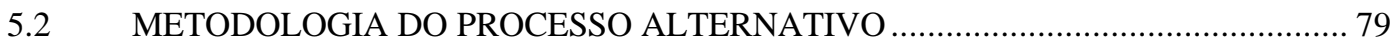

5.3 EXTRAÇÃO DAS PASTILHAS DOS CORPOS-DE-PROVA …................................ 80

5.4 EXECUÇÃO DAS PLACAS DE ARGAMASSA PROJETADA …............................... 83

5.5 SERRAGEM DAS PASTILHAS DAS PLACAS DE ARGAMASSA PROJETADA .... 86

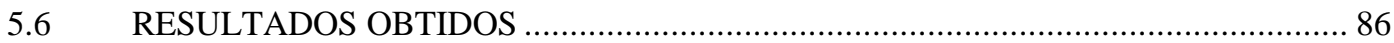

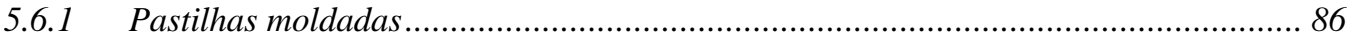

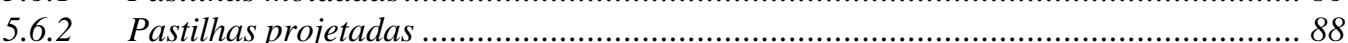

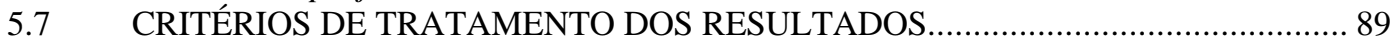

5.8 APLICAÇÃO DO CRITÉRIO DE CHAUVENET ................................................... 90

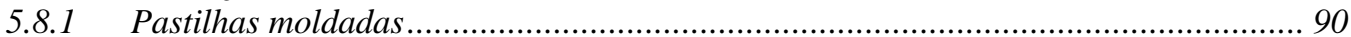

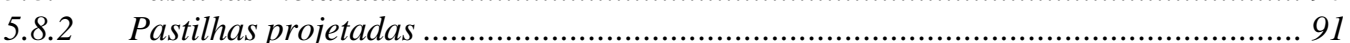

5.9 CRITÉRIO DE DESCLASSIFICAÇÃO DAS PASTILHAS …….................................. 92

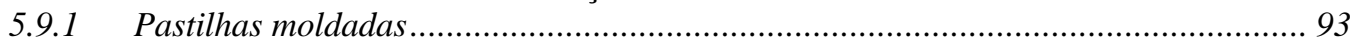

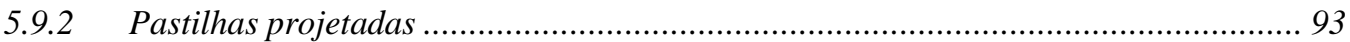

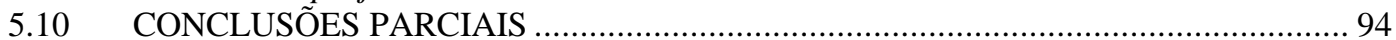

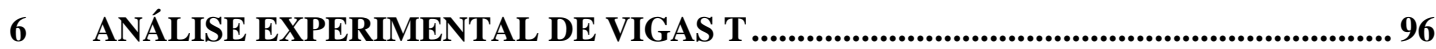

6.1 DESCRIÇÃO DO MODELO EXPERIMENTAL ……................................................. 96

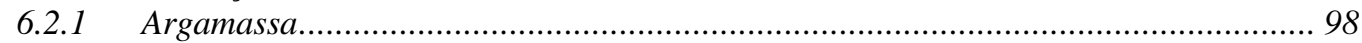

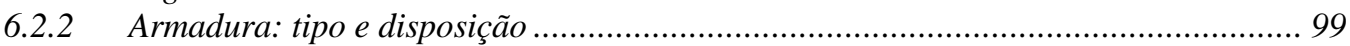

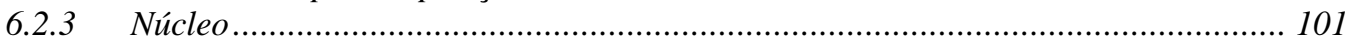

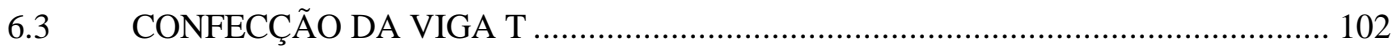

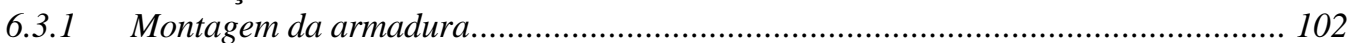

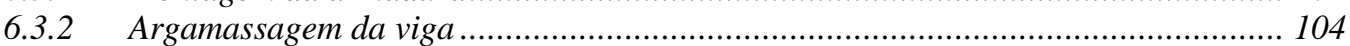

6.4 ESQUEMA ESTÁTICO, CARREGAMENTO E INSTRUMENTAÇÃO ..................... 107

6.5 RESULTADOS OBTIDOS E ANÁLISE DOS RESULTADOS .................................. 110

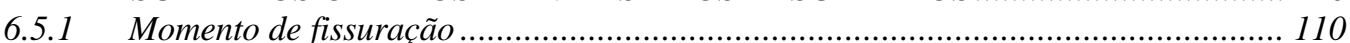

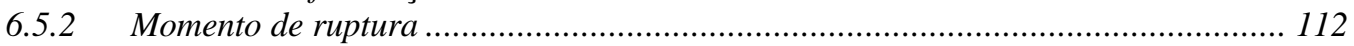

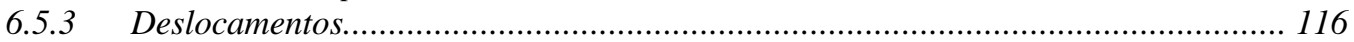

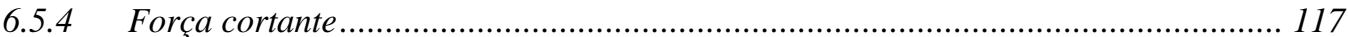

6.6 CONCLUSÕES PARCIAIS 
7 ANÁLISE EXPERIMENTAL DE PAINÉIS À FLEXÃO................................................... 120

7.1 DESCRIÇÃO DOS MODELOS EXPERIMENTAIS ………..................................... 120

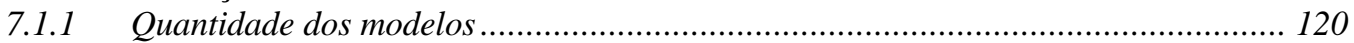

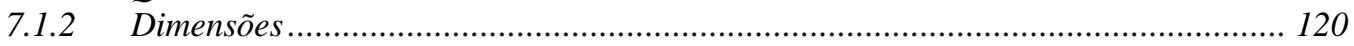

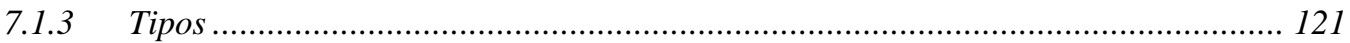

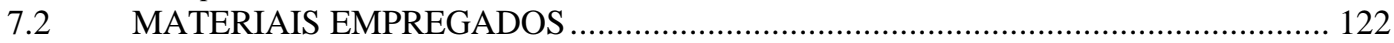

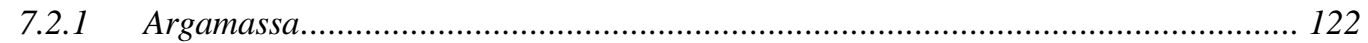

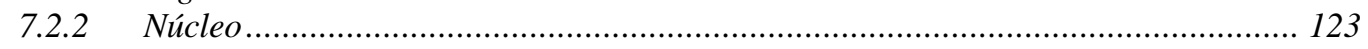

7.2.3 Armadura: tipo e disposição ...................................................................... 124

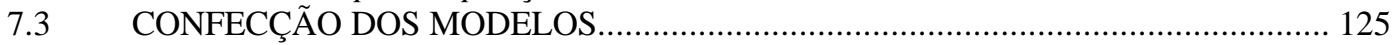

7.4 ESQUEMA ESTRUTURAL E INSTRUMENTAÇÃO …........................................... 128

7.5 RESULTADOS OBTIDOS E ANÁLISE DOS RESULTADOS …............................... 133

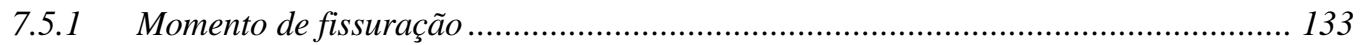

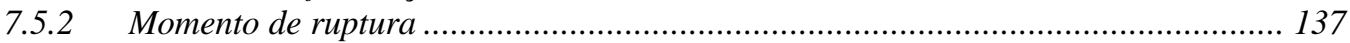

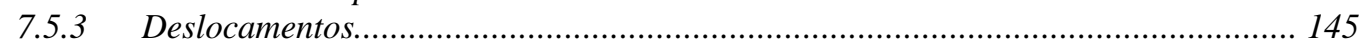

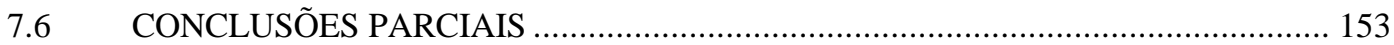

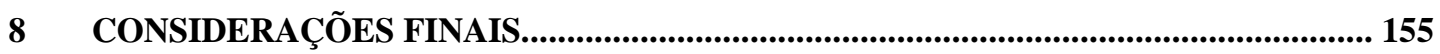

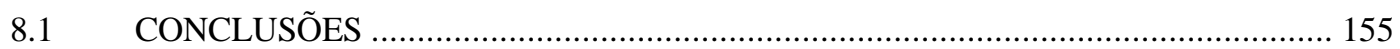

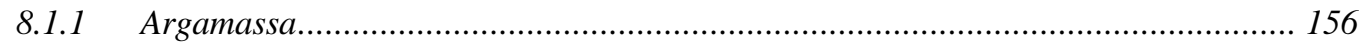

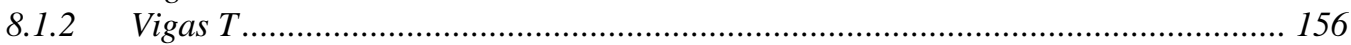

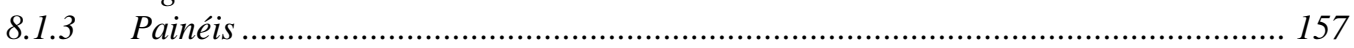

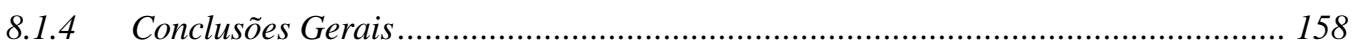

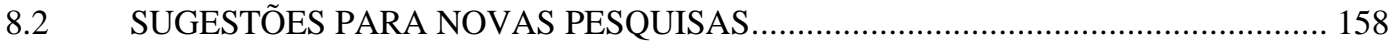

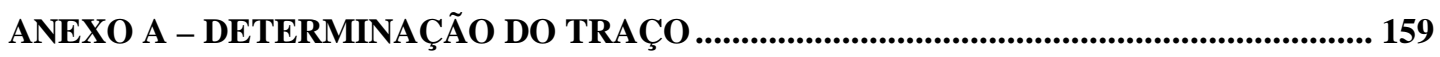

ANEXO B - CRITÉRIOS DE TRATAMENTO DOS RESULTADOS ....................................... 164

ANEXO C - ENSAIO DO PROTÓTIPO DA VIGA T (VT 01) ................................................. 176

ANEXO D - ENSAIO DE COMPRESSÃO EM PAINÉIS TIPO SANDUÍCHE......................... 186

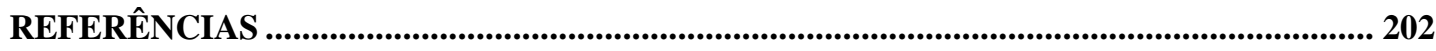

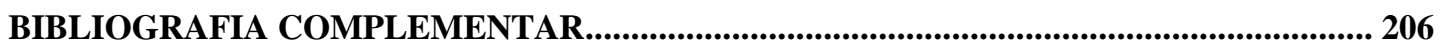




\section{RESUMO}

BERTINI, A. A. Estruturas tipo sanduíche com placas de argamassa projetada. São Carlos, 2002. 209p. Tese (Doutorado) - Escola de Engenharia de São Carlos, Universidade de São Paulo.

Elementos tipo sanduíche, com placas de argamassa projetada, têm sido utilizados na construção de edificações em alguns países, inclusive no Brasil, apresentando boas características de resistência mecânica, térmica e acústica. De maneira geral, a aplicação desse tipo de elemento tem se restringido a obras de edificações, sendo utilizado principalmente como painéis de fechamento, portantes ou não, existindo ainda um potencial a ser explorado em obras de infra-estrutura, tais como: muros de arrimo, canais, galerias e reservatórios de água. Apesar de ser um método utilizado na construção de edificações, existem dúvidas, tais como: resistência efetiva da argamassa projetada, colaboração entre as placas resistentes em função do tipo de núcleo, modo de combater os efeitos de retração da argamassa, etc. Apresenta-se neste trabalho um estudo sobre a resistência efetiva da argamassa projetada, no qual se obteve que a sua resistência é de aproximadamente $80 \%$ da resistência à compressão de corpos-de-prova cilíndricos. Realizaram-se ainda ensaios para analisar a ligação entre elementos tipo sanduíche e seu comportamento à flexão, que comprovam o bom desempenho estrutural. Acredita-se que essa técnica de construção sanduíche possa ser aplicada em obras de infra-estrutura de interesse social, trazendo vantagens tecnológicas e econômicas em relação a sistemas tradicionais.

Palavra-chave: estruturas tipo sanduíche; argamassa projetada; resistência da argamassa, ligações, flexão. 


\section{ABSTRACT}

BERTINI, A. A. Sandwich-type structures with plates made of projected mortar. São Carlos, 2002. 209p. Thesis (PhD) - Escola de Engenharia de São Carlos, Universidade de São Paulo.

Sandwich-type elements, with plates made of projected mortar, have been used in the construction of buildings in some countries, including Brazil, showing expressive thermical, acoustical and mechanical strength characteristics. In general, the application of this kind of element have been limited to buildings, mainly used as cladding panels, with carrying load capacity or not, and have other potential uses in infra-structural works to be explored such as bearing walls, channels, and water reservoirs. Although it is a method that have been conventionally applied in the construction of buildings, there are uncertainties in some parameters, like the effective strength of the projected mortar, interaction between the plates related to the type of core, the mode against shrinkage of the mortar etc. It is showed in this work a study concerning the effective strength of the projected mortar. As a result of a series of tests in walls made of projected mortar, it is determined that the effective strength of the projected mortar is $80 \%$ of that one measured from cylindrical specimens in compression tests. As well, some tests have been executed to analise the bending behaviour and the connections between the plates of the sandwich-type specimens, which demonstrated a relatively high structural performance. It is believed that this technical solution can be well applied to public works of social interest, and can offer technological and economical advantages in contrast to the traditional systems.

Keywords: sandwich-type structure; projected mortar; mortar strength, connections, bending behaviour. 


\section{LISTA DE FIGURAS}

FIGURA 2.1 - CONSTITUINTES DE UM ELEMENTO TIPO SANDUÍCHE.............................................. 9

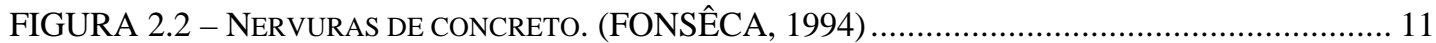

FIGURA 2.3 - CONECTORES RÍGIDOS EM UMA DIREÇÃO (PCI COMMITTEE REPORT, 1997).......... 12

FIGURA 2.4 - CONECTORES RÍGIDOS EM DUAS DIREÇÕES (PCI COMMITTEE REPORT, 1997) ....... 13

FIGURA 2.5 - BLOCOS DE CONCRETO (PFEIFER \& HANSON, 1965) ......................................... 14

FIGURA 2.6 - CONECTORES FLEXÍVEIS (PCI COMMITTEE REPORT, 1997) _................................ 15

FIGURA 2.7 - DISPOSIÇÃO DOS CONECTORES FLEXÍvEIS.(X = CONECTORES FLEXÍVEIS)....................... 16

FIGURA 2.8 - DISPOSIÇÃO DOS CONECTORES EM PAINÉIS NERVURADOS NÃO COMPOSTOS................... 16

FIGURA 2.9 - DISPOSIÇÃO DO CONECTOR RÍGIDO EM DUAS DIREÇÕES PARA PAINÉIS NÃO COMPOSTOS.

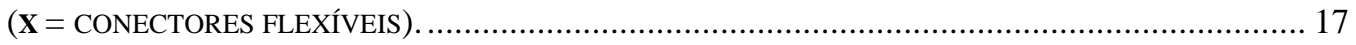

FIGURA 2.10 - DISPOSIÇÃO DE CONECTORES RÍGIDOS EM UMA DIREÇÃO PARA PAINÉIS NÃO

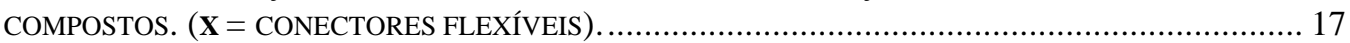

FIGURA 2.11 - PRÉ-PAINEL DE POLIESTIRENO COM ARMADURA ……........................................ 18

FIGURA 2.12 - PIZZA HUT - RIBEIRÃo PRETO - SP …………................................................. 22

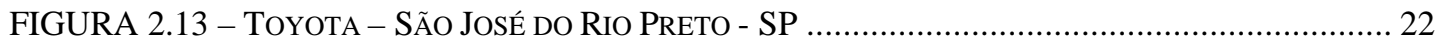

FIGURA 2.14 - CONDOMÍNIO GREEN PARK - SÃO JOSÉ DO RIO PRETO - SP..................................... 22

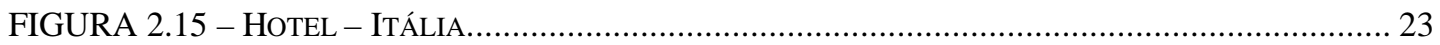

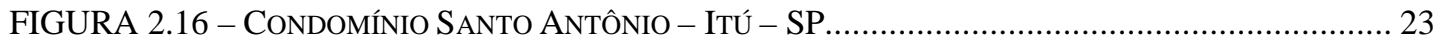

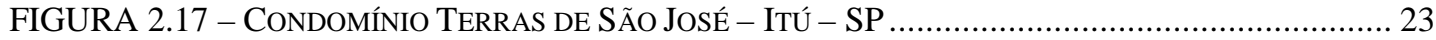

FIGURA 2.18 - SEQÜÊNCIA EXECUTIVA DA COLOCAÇÃO DO EPS (TEXEIRA, 1999), ........................ 24

FIGURA 2.19 - CONCRETAGEM DA FACE SUPERIOR DO PROTÓTIPO (TEXEIRA, 1999)_...................... 25

FIGURA 2.20 - VISTA DO PROTÓTIPO CONCLUÍDO (TEXEIRA, 1999). ......................................... 25

FIGURA 2.21- A) CANAL De SEÇão Retangular; B) Muro de ARRimo em L; C) Galeria DE SEÇão

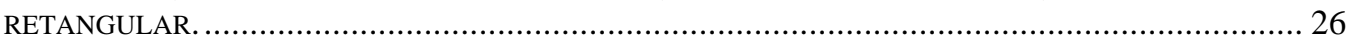

FIGURA 3.1 - TIPOS DE COMPOSIÇÃO DE UMA SEÇÃO SANDUÍCHE. a) COMPLETAMENTE COMPOSTA; b) PARCIALMENTE COMPOSTA; c) NÃO-COMPOSTA; d) NÃO-COMPOSTA COM UMA FACE RESISTENTE

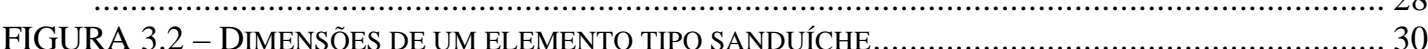

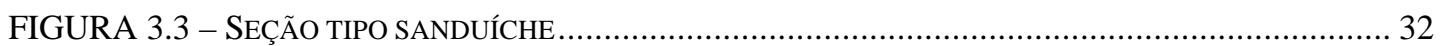

FIGURA 3.4 - SEÇÃO DE MESMA RIGIDEZ. DIAGRAMA DE TENSÕES .................................................... 33

FIGURA 3.5 - SEÇ̃̃O TRANSVERSAL TíPICA DOS PAINÉIS ENSAIADOS POR BANSUNBUL ET AL (1991). A) SHEAR CONNECTORS COM FIOS; B) SHEAR CONNECTORS COM FIOS DE TELA SOLDADA; C)

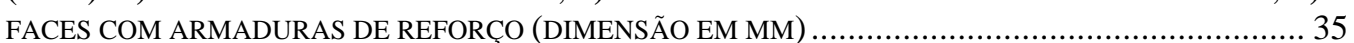

FIGURA 3.6 - DETALHES DOS PAINÉIS ENSAIADOS POR LEE ET AL (1986) ....................................... 37

FIGURA 3.7 - GRÁFICO FORÇA X DESLOC. DOS PAINÉIS ENSAIADOS POR LEE ET AL (1986) ............... 38

FIGURA 3.8 - CARACTERÍSTICAS GERAIS DO PRÉ-PAINEL (HANAI \& TAKEYA, 1994) ..................... 39

FIGURA 3.9 - ESQUEMA DE CARREGAMENTO E INSTRUMENTAÇÃO DOS MODELOS (HANAI \&

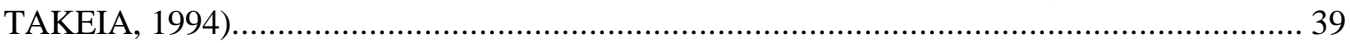

FIGURA 3.10 - GEOMETRIA DOS PAINÉIS ENSAIADOS POR BUSH \& STINE (1986) ......................... 41

FIGURA 3.11 - GEOMETRIA DA TRELIÇA METÁLICA UTILIZADA NOS ENSAIOS DE BUSH \& STINE (1986)

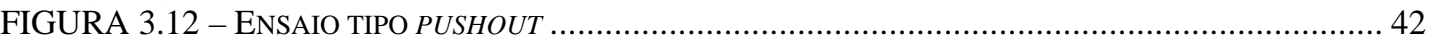

FIGURA 3.13 - GRÁFICO CARGA X DESLOCAMENTO DOS ENSAIOS À FLEXÃO REALIZADOS POR STINE

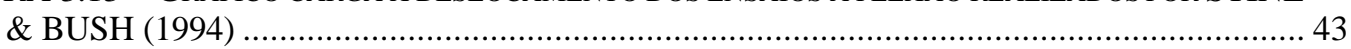

FIGURA 3.14 - GRÁFICO MOMENTO DE FISSURAÇÃO X DESLOCAMENTO SEGUNDO O TIPO DE ISOLANTE

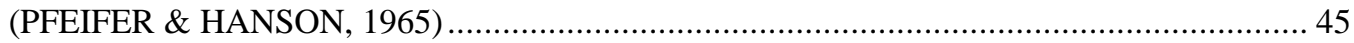

FIGURA 3.15 - GRÁFICO MOMENTO X DESLOCAMENTO SEGUNDO O TIPO DE CONECTOR (PFEIFER \&

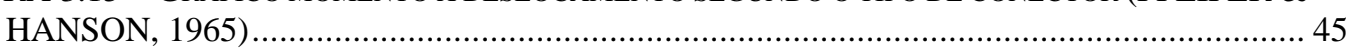

FIGURA 3.16 - TIPOS DE PAINÉIS NERVURADOS ESTUDADOS POR PFEIFER \&HANSON(1965)....... 46

FIGURA 3.17 - GRÁFICO MOMENTO X DESLOCAMENTO DE PAINÉIS NERVURADOS (PFEIFER \& HANSON, 1965) 
FIGURA 3.18 - ETAPAS DE CÁLCULO PARA UM GRADIENTE DE TEMPERATURA (EINEA ET AL., 1991)

FIGURA 3.19 - VARIAÇÃO DE TEMPERATURA ATRAVÉS DE UMA SEÇÃO TIPO SANDUÍCHE (EINEA ET AL., 1991).....

FIGURA 4.1 - ESQUEMA DO SISTEMA DE PRÉ-UMIDIFICAÇãO (FIGUEIREDO, 1992) .........................54

FIGURA 4.2 - CASA CONSTRUÍDA PELA CÓDIGO ENGENHARIA EM COTIA-SP ....................................5 57

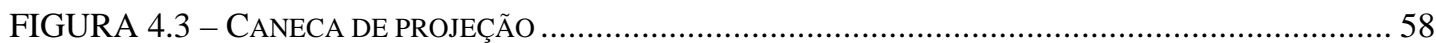

FIGURA 4.4 - DETALHES DOS FUROS DE SAÍDA DA ARGAMASSA....................................................... 59

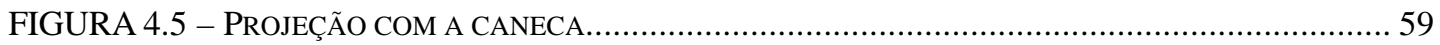

FIGURA 5.1 - MoLDAGEM DA PLACA (FIGUEIREDO, 1997) .................................................... 78

FIGURA 5.2 - ESQUEMA DAS PASTILHAS EXTRAÍDAS DOS CORPOS-DE-PROVA................................. 80

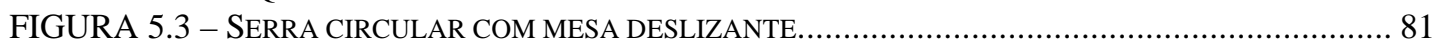

FIGURA 5.4 - DETALHE DO CORPO-DE-PROVA DURANTE O PROCESSO DE SERRAGEM.......................... 81

FIGURA 5.5 - DETALHE DO ELEMENTO DE DIMENSÕES 3CM X 6CM X 20CM ……………................. 82

FIGURA 5.6 -DA ESQUERDA PARA A DIREITA: PASTILHAS DE TOPO, MEIO E BASE. ........................... 82

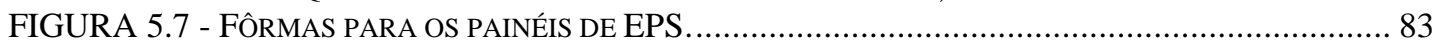

FIGURA 5.8 - POSICIONAMENTO DOS PAINÉIS DE PROJEÇÃO........................................................ 84

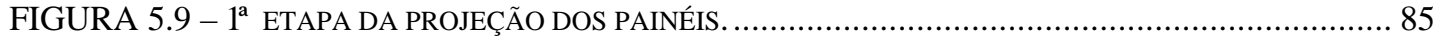

FIGURA 5.10 - RETIFICAÇÃO DA ESPESSURA DOS PAINÉIS. ......................................................... 85

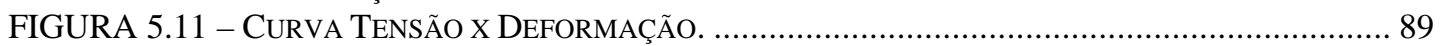

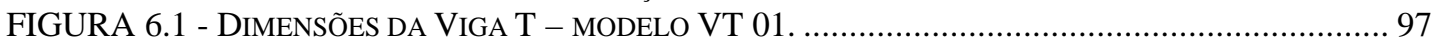

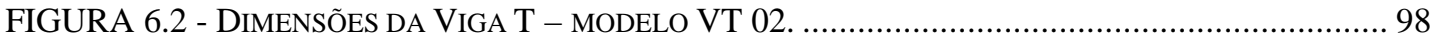

FIGURA 6.3 - DiAGRAMA FoRÇA X DEFORMAÇ̃̃o DA BARRA DE 6.3MM .......................................... 99

FIGURA 6.4 - DiAGRAMA FoRÇA X DEFORMAÇÃo DA BARRA DE 8MM......................................... 100

FIGURA 6.5 - DETALHE DE CORTE E DOBRAMENTO DA TELA SOLDADA. ........................................ 100

FIGURA 6.6 - POSICIONAMENTO DA ARMADURA DE TRAÇÃO NA VT 02 …….............................. 101

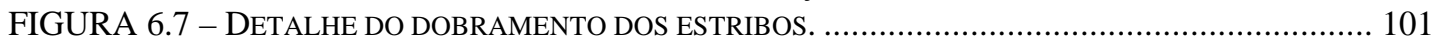

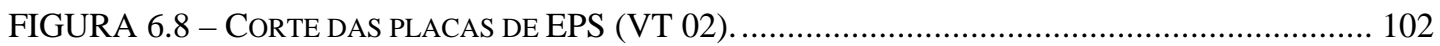

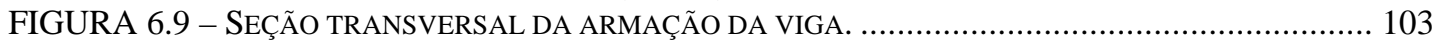

FIGURA 6.10 - DETALHE DOS ESTRIBOS E DA INTERSECÇÃO DOS ELEMENTOS SANDUÍCHE. .............. 103

FIGURA 6.11 - DETALHE DA CONEXÃO ENTRE A TELA DA ALMA E A TELA DA MESA. DisTRIBUIÇÃO DA

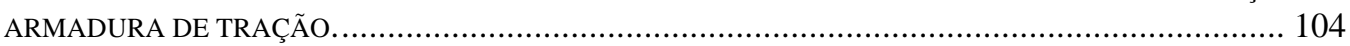

FIGURA 6.12 - VIGA NA POSIÇÃO VERTICAL, PREPARADA PARA O INÍCIO DA ARGAMASSAGEM........ 105

FIGURA 6.13 - ARGAMASSAGEM DA MESA E DA ALMA. PRIMEIRA ETAPA...................................... 105

FIGURA 6.14 - FINAL DA PRIMEIRA ETAPA DA ARGAMASSAGEM. .................................................... 106

FIGURA 6.15 - INÍCIO DA SEGUNDA ETAPA DA ARGAMASSAGEM............................................... 106

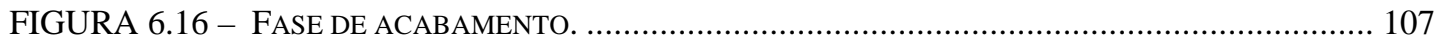

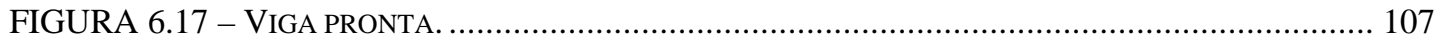

FIGURA 6.18 - ESQUEMA ESTÁTICO, CARREGAMENTO E INSTRUMENTAÇ̃̃o - VT 01 E $02 . . . . . . . . . . . . . . .108$

FIGURA 6.19 - Modelo VT 02. DetalHe DOS APOIO E DO MECANISMO DE APLICAÇão DE CARGA:

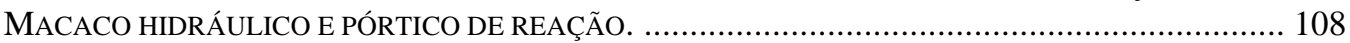

FIGURA 6.20 - POSICIONAMENTOS DOS EXTENSÔMETROS. .............................................................. 109

FIGURA 6.21 - CONFIGURAÇ̃̃O DAS FISSURAS PRÓXIMA AO APOIO DO MODELO VT 02 ................. 111

FIGURA 6.22 - CONFIGURAÇÃO DAS FISSURAS NO MEIO DO VÃO DO MODELO VT 02 . ..................... 112

FIGURA 6.23 - DiAGRAMA FORÇA X DEFORMAÇÃo DO AÇO NO ENSAIO DE FLEXÃO. ....................... 113

FIGURA 6.24 - DEFORMAÇÕES AO LONGO DA LARGURA - SUPERFÍCIE SUPERIOR DA MESA............... 114

FIGURA 6.25 - DEFORMAÇÕES AO LONGO DA LARGURA - SUPERFÍCIE INFERIOR DA MESA.............. 114

FIGURA 6.26 - DEFORMAÇÃO AO LONGO DA ALTURA DA VIGA. ................................................. 115

FIGURA 6.27 - COMPARAÇÃO ENTRE OS DESLOCAMENTOS TEÓRICOS E EXPERIMENTAIS.................. 117

FIGURA 6.28 - GRÁFICO FORÇA X DEFORMAÇÃO PARA OS ESTRIBOS.......................................... 118

FIGURA 7.1 - DIMENSÕES DOS PAINÉIS E CONFIGURAÇÕES DAS NERVURAS ...................................... 121

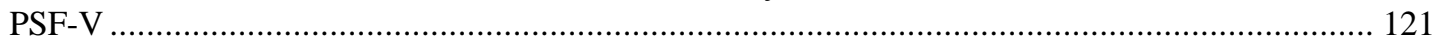

FIGURA 7.2 - PRÉ-PAINEL (NÚCLEO DE EPS + TELA SOLDADA) ……....................................... 123

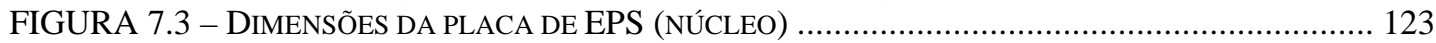

FIGURA 7.4 - DETALHE DO PRÉ-PAINEL (EPS + TELA SOLDADA) ……....................................... 124

FIGURA 7.5 - ESPAÇAMENTOS DA TELA SOLDADA ………….............................................. 124

FIGURA 7.6 - ARMADURA DE CISALHAMENTO DAS NERVURAS (DETALHE DE UM PEDAÇO DO PRÉPAINEL) 
FIGURA 7.7 - PAINÉIS POSICIONADOS PARA PROJEÇ̃̃O DA ARGAMASSA …...................................... 126

FIGURA 7.8 - PRIMEIRA ETAPA DA PROJEÇÃO DA ARGAMASSA ………....................................... 127

FIGURA 7.9 - SEgUNDA ETAPA DA PROJEÇão dA ARGAMASSA. SARRAFOS NAS LATERAIS ............... 127

FIGURA 7.10 - ESQUEMA ESTÁTICO E DE CARREGAMENTO ……....................................................... 128

FIGURA 7.11 - APARATO PARA O CARREGAMENTO NOS TERÇOS DO VÃO DO PAINEL …………….... 129

FIGURA 7.12 - PÓRTICO DE REAÇÃO UTILIZADO NOS ENSAIO DE FLEXÃO DOS PAINÉIS ..................... 129

FIGURA 7.13 - POSIÇÃO DOS TRANSDUTORES ELÉTRICOS AO LONGO DO PAINEL .............................. 130

FIGURA 7.14 - DISPOSIÇÃO DOS EXTENSÔMETROS NA PLACA COMPRIMIDA.................................... 130

FIGURA 7.15 - DISPOSIÇÃO DOS EXTENSÔMETROS DA ARMADURA DE TRAÇÃO ………………….... 131

FIGURA 7.16 - DISPOSIÇÃO DOS EXTENSÔMETROS COLADOS NOS CONECTORES DE LIGAÇÃO DAS

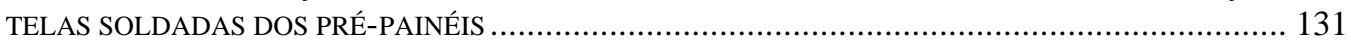

FIGURA 7.17(a) - DISPOSIÇÃO DOS EXTENSÔMETROS COLADOS NA ARMADURA DAS NERVURAS .... 132

FIGURA 7.17(b) - DISPOSIÇÃO DOS EXTENSÔMETROS COLADOS NA ARMADURA DAS NERVURAS .... 132

FIGURA 7.18 - ENSAIO DE FLEXÃO EM UMA ETAPA PRÓXIMA DA RUPTURA..................................... 137

FIGURA 7.19 - FISSURAS NUMA ETAPA DO ENSAIO PRÓXIMA DA RUPTURA - PSF-IV …………......... 138

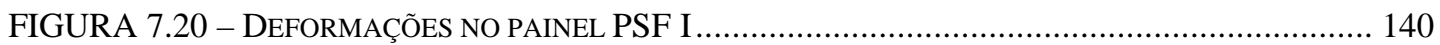

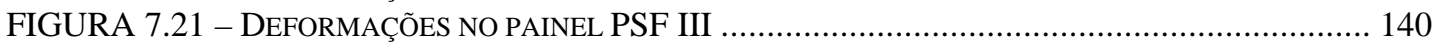

FIGURA 7.22 - DEFORMAÇÕES NO PAINEL PSF II............................................................... 142

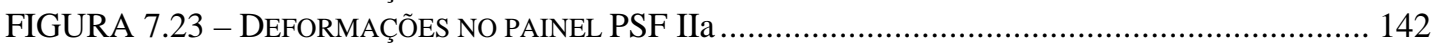

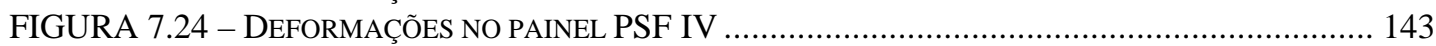

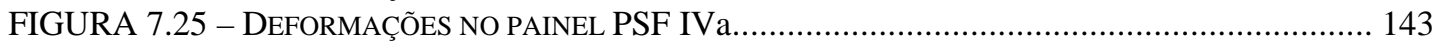

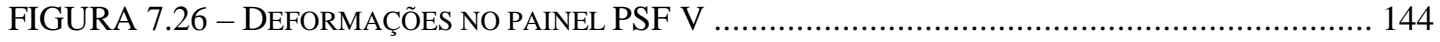

FIGURA 7.27 - DEFORMAÇÕES NO PAINEL PSF Va _........................................................................ 144

FIGURA 7.28 - GRÁFICO FORÇA X DESLOCAMENTOS PARA TODO OS MODELOS ENSAIADOS À FLEXÃO

146

FIGURA 7.29 - COMPARAÇÃo TEÓRICA X EXPERIMENTAL DO GRÁFICO FORÇAXDESLOC. DOS

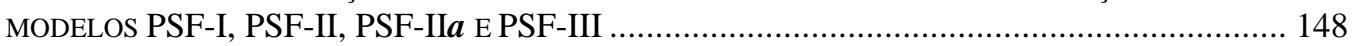

FIGURA 7.30 - COMPARAÇ̃̃o TEÓRICA X EXPERIMENTAL DO GRÁFICO FORÇAXDESLOC. DOS

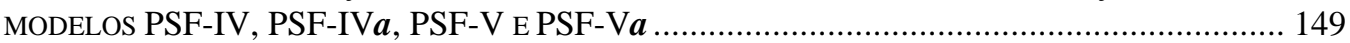

FIGURA 7.31 - COMPARAÇÃo TEÓRICA X EXPERIMENTAL DO GRÁFICO FORÇAXDESLOC. DOS MODELOS PSF-I, PSF-II, PSF-II $a$ E PSF-III................................................................... 150

FIGURA 7.32 - COMPARAÇÃo TEÓRICA X EXPERIMENTAL DO GRÁFICO FORÇAXDESLOC. DOS

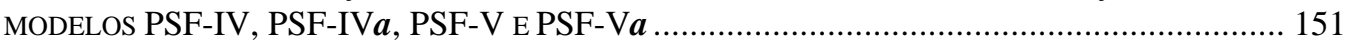

FIGURA 7.33 - COMPARAÇÃO TEÓRICA X EXPERIMENTAL PSF III. C = 0,13 …........................... 152 


\section{LISTA DE TABELAS}

TABELA 2.1 - ESPECIFICAÇÕES DOS PAINÉIS UTILIZADOS NOS E.U.A........................................... 19

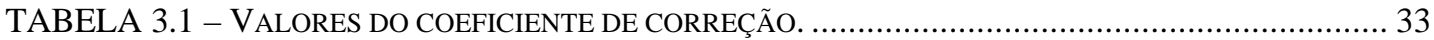

TABELA 3.2 - DETALHES DOS MODELOS DE PEFEIFER \& HANSON (1965) ……........................... 44

TABELA 3.3 - COEFICIENTES DE SEGURANÇA PARA FISSURAÇÃO EM PAINÉIS SANDUÍCHE SUBMETIDOS

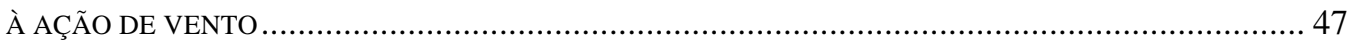

TABELA 4.1 - VALORES-LIMITES PARA CURVAS GRANULOMÉTRICAS (AGREGADO TOTAL) UTILIZADOS EM CONCRETO PROJETADO

TABELA 5.1 - RESISTÊNCIA À COMPRESSÃO DAS PASTILHAS EXTRAÍDAS DOS CORPOS-DE-PROVA CILÍNDRICOS.

TABELA 5.2 - RESISTÊNCIA À COMPRESSÃO DAS PASTILHAS EXTRAÍDAS DAS PLACAS. ..................... 88

TABELA 5.3 - RESISTÊNCIA À COMPRESSÃO DOS CORPOS-DE-PROVA CILÍNDRICOS .............................. 88

TABELA 5.4 - RESUMO DA ANÁLISE DA RESISTÊNCIA DAS PASTILHAS EXTRAíDAS DE CORPOS-DEPROVA CILÍNDRICOS, ATRAVÉS DO CRITÉRIO DE CHAUVENET.................................................. 91

TABELA 5.5 - RESUMO DA ANÁLISE DE RESISTÊNCIA DAS PASTILHAS PROJETADAS, ATRAVÉS DO

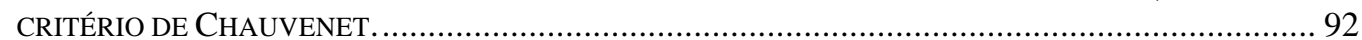

TABELA 5.6 - RESUMO DA ANÁLISE DA RESISTÊNCIA DAS PASTILHAS MOLDADAS, ATRAVÉS DO CRITÉRIO DA DESCLASSIFICAÇ̃̃O DAS PASTILHAS. ............................................................. 93

TABELA 5.7 - RESUMO DA ANÁLISE DA RESISTÊNCIA DAS PASTILHAS EXTRAÍDAS DAS PLACAS, ATRAVÉS DO CRITÉRIO DA DESCLASSIFICAÇÃO DAS PASTILHAS. …………………….................... 93

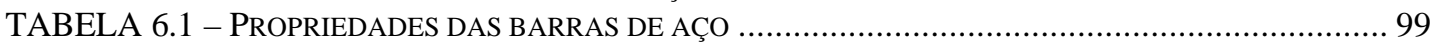

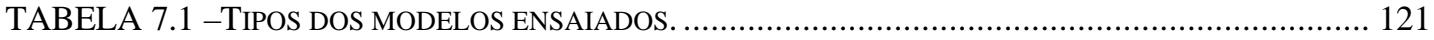

TABELA 7.2 - CONTROLE DA ARGAMASSA UTILIZADA NA CONFECÇÃO DOS MODELOS .................... 122

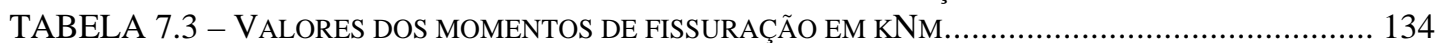

TABELA 7.4 - VALORES DOS MOMENTOS DE FISSURAÇ̃̃O EM KNM................................................ 136

TABELA 7.5 - VALORES TEÓRICOS E EXPERIMENTAIS DOS MOMENTOS DE RUPTURA EM KNM ......... 138 


\section{INTRODUÇÃO}

"John Montagu era o quarto conde de Sandwich, cidadezinha localizada ao sul da Inglaterra, no condado de Kent. Em uma noite de 1762, ele pediu que os criados the trouxessem pedaços de carne e queijo envolvidos por duas fatias de pão. $O$ conde estava jogando cartas e não queria interromper a partida nem sujar o baralho de gordura. E, assim, inventou uma verdadeira mania mundial". ${ }^{l}$

John Montagu não sabia que sua idéia, concebida no século XVIII, ficaria conhecida no mundo inteiro e ainda seria adaptada por engenheiros para outros fins, a partir do século XX, na aplicação em diversos ramos da Engenharia, como construção civil, aeronáutica, automobilística etc.

Nesses casos, um "sanduíche" consiste basicamente de duas placas de um material resistente, intercaladas por uma camada de outro material, em geral de baixa densidade e resistência inferior à das placas. A resistência desse conjunto à flexão é muito maior que a de uma placa maciça, do mesmo material e do mesmo peso que as duas placas externas.

\subsection{IMPORTÂNCIA DO TEMA}

A idéia da "Construção Sanduíche" pode proporcionar uma economia no consumo de materiais de melhor desempenho através da combinação com materiais menos nobres, podendo-se ainda conseguir elementos mais leves e de adequada resistência. Talvez esses fatores tenham sido a causa do grande impulso de sua utilização nas mais diversas aplicações.

De maneira geral, a aplicação de elementos tipo sanduíche tem-se restringido a edificações, sendo eles utilizados como painéis de fechamento (portantes ou não), forros e lajes. Esse método construtivo proporciona boas características de resistência

\footnotetext{
${ }^{1}$ Extraído de um folheto de propaganda da Patê Sadia em março de 1999.
} 
e de isolamento termo-acústico, podendo ser uma alternativa vantajosa em relação a outros tipos tradicionais de construção, como os que utilizam paredes de alvenaria ou sistemas pré-fabricados de concreto, por exemplo.

As placas resistentes podem ser dos mais variados materiais. Segundo COLLINS (1954), o primeiro exemplo do uso da idéia do sanduíche, é atribuído aos americanos, que, já em 1906, experimentavam um engenhoso processo de construção de painéis tipo "tilt-up". Os painéis ou as paredes inteiras eram moldados na posição horizontal e o mais próximo possível do local definitivo, onde eram colocados na posição vertical, após a cura.

O método consistia em moldar um grande painel, no qual a plataforma que servia de fôrma seria erguida junto com esse painel. $O$ efeito sanduíche era conseguido através da moldagem da placa inferior de $50 \mathrm{~mm}$ de espessura, com uma camada de areia (também de $50 \mathrm{~mm}$ ) sobre ela, e uma segunda placa de $50 \mathrm{~mm}$ sobre a camada de areia. A areia, na verdade, servia apenas para auxiliar na concretagem da segunda placa e, durante o erguimento do painel, era lavada com uma mangueira de incêndio. A seção transversal final consistia em duas placas de concreto, com o colchão de ar deixado pela areia lavada. As placas eram ligadas por conectores.

Na década após 1930 foi desenvolvido e patenteado pelo Forest Products Laboratory, nos Estados Unidos, um método construtivo para pré-fabricação de habitações com painéis tipo sanduíche.

Esses painéis eram utilizados como paredes, telhados e pisos, que consistiam de faces de madeira compensada, coladas a enrijecedores longitudinais, também de madeira. Após a colagem, os vazios entre as faces eram preenchidos com material isolante. Posteriormente desenvolveu-se um núcleo de papelão, tipo "favo de mel", tratado com resina fenolítica, o qual substituiu os enrijecedores, fazendo com que o painel trabalhasse como um verdadeiro sanduíche.

ROBERTS (1951) descreve um método desenvolvido para a construção de uma usina de celulose em Vancouver, no Canadá. Nessa obra foram utilizados painéis de $1,83 \mathrm{~m}$ por $3,05 \mathrm{~m}$, com placa externa de $50,8 \mathrm{~mm}$ e placa interna de $38 \mathrm{~mm}$, sendo o núcleo de isolante constituído de "celular glass", com 50,8 mm de espessura. 
Alguns tipos de painéis sanduíche, bastante empregados na América do Norte e na Europa, utilizam placas de concreto como faces. Estas podem ser pré-moldadas em usinas ou moldadas no local. Quando os elementos tipo sanduíche são prémoldados, pode-se fazer uso da protensão com aderência inicial (PCI COMMITTEE REPORT, 1997). Este tipo de painel geralmente possui de 4 a $17 \mathrm{~m}$ de comprimento por 1 a 2,4 m de largura. O seu uso tem-se verificado em habitações, edificações comerciais de baixa altura e armazéns.

MACHADO JR. (1991) desenvolveu um método construtivo para habitação, que tinha painéis tipo sanduíche como elemento principal, com faces de argamassa armada. O núcleo era de espuma rígida de poliuretano expandido "in loco", diferenciando-se de outros métodos que, na sua grande maioria, utilizam painéis isolantes pré-expandidos. A ligação entre as placas resistentes era garantida apenas pela espuma rígida. O painel necessitava da montagem na obra, sendo utilizado como paredes internas e externas.

De acordo com PICKARD (1990), nos Estados Unidos, em 1967, Victor Weisman patenteou um método que hoje encontra grande número de variações e patentes no mundo inteiro. Esse método é constituído basicamente de pré-painéis de material isolante (geralmente poliestireno ou poliuretano), armados com telas soldadas, dispostas em cada uma das faces e interligadas por meio de barras eletrosoldadas, numa configuração tridimensional, que gera uma boa rigidez.

Os pré-painéis são montados na obra. A resistência do sistema é garantida pelo revestimento de argamassa, executado em cada uma das faces do isolante, por métodos tradicionais de emboçamento ou por processos mais modernos de projeção da argamassa sob pressão.

O potencial de utilização de métodos construtivos semelhantes ao patenteado por Victor Weisman é enorme. Podem ser aplicados em infra-estruturas, visando principalmente Obras de Interesse Social, tais como muros de arrimo, canais de drenagem, galerias, reservatórios de água, entre outras. ${ }^{2}$

\footnotetext{
${ }^{2} \mathrm{O}$ termo Obras de Interesse Social é entendido aqui como obras de grande importância para a sociedade, especialmente para as pessoas mais pobres, carentes de obras de infra-estrutura, que moram na zona rural ou em locais distantes dos grandes centros.
} 
Por serem aplicadas com muita repetição ou por serem de grande extensão, essas obras correspondem a uma parcela significativa nos custos de infra-estrutura, o que torna importante o desenvolvimento de novas técnicas, na tentativa de oferecer elementos estruturais eficientes e mais baratos.

Com a utilização deste tipo de composição estrutural e respectiva tecnologia na execução dessas obras de infra-estrutura, pode-se usufruir as mesmas vantagens do método utilizado em edificações, com moldagem posterior das faces resistentes, tais como:

i) Estruturas rígidas e resistentes;

ii) Eliminação de fôrmas;

iii) Rapidez de execução

iv) Estrutura monolítica;

v) Redução de custos;

vi) Racionalização da construção, utilizando técnicas de projeção de argamassa;

vii) Possibilidade de execução em lugares distantes ou de difícil acesso;

viii) Possibilidade de utilização de mão-de-obra pouco especializada;

ix) Possibilidade de utilização de rejeitos industriais ou resíduos agrícolas na confecção dos núcleos;

x) Possibilidade de execução da obra através da autoconstrução.

A economia no consumo de materiais de melhor desempenho (argamassa) pode ser conseguida pela combinação com materiais menos nobres (núcleo), adotando-se a idéia da estrutura mista ("sanduíche”).

Para que essas vantagens sejam transferidas na sua totalidade para obras de infra-estrutura, são necessárias algumas adaptações.

Apesar de este método (pré-painéis com posterior projeção da argamassa) ser utilizado na construção de edificações em vários países, entre os quais Estados Unidos, Itália, Austrália, Venezuela, Brasil inclusive, ainda existem dúvidas que se manifestam dentro do processo construtivo, como por exemplo resistência efetiva da argamassa projetada, colaboração entre as placas resistentes em função do tipo de núcleo, como combater os efeitos de retração da argamassa etc.

Na prática, tais dúvidas somente não impedem a aplicação do método porque são considerados muitos dados obtidos da experiência dos construtores, e os esforços 
solicitantes são relativamente pequenos, havendo até mesmo sobra de resistência em alguns casos.

Em obras de infra-estrutura, a magnitude e o tipo de esforços são diferentes daqueles existentes em edificações. O empirismo deve ser posto de lado, e dados mais precisos devem ser considerados.

A fim de elucidar as dúvidas, possibilitando a aplicação do método e obedecendo os requisitos de funcionalidade, segurança e economia, devem ser melhor analisados: comportamento estrutural dos elementos, dimensionamento, formas mais adequadas para aplicação, tipos de ligação entre os elementos e esforços que devem ser transmitidos por estas ligações, arranjos de armadura mais adequados para as ligações, custos comparativos com soluções tradicionais etc.

$\mathrm{Na}$ tentativa de desenvolver uma alternativa de construção com painéis tipo sanduíche para obras de infra-estrutura, certamente também haverá contribuição para a solução de alguns problemas existentes no processo de construção de habitações.

\subsection{OBJETIVOS}

Os objetivos principais deste trabalho são o estudo e o desenvolvimento de estruturas tipo sanduíche, já aplicadas em larga escala no Brasil e no exterior em obras de edificações. Propõe-se ampliar o potencial de aplicação desse tipo de método construtivo em obras de infra-estrutura urbana e rural, enquadradas como Obras de Interesse Social, como, por exemplo, muros de arrimo, canais de drenagem, galerias e reservatórios de água, entre outras.

Como objetivos específicos podem ser enumerados os seguintes:

i) Estudo da correlação matemática entre as resistências da argamassa à compressão, determinadas de duas maneiras: uma usual com corpos-de-prova cilíndricos de $10 \mathrm{~cm}$ x $20 \mathrm{~cm}$ moldados com argamassa comum, e outra relativa à argamassa projetada, obtida com prismas de base retangular de $3 \mathrm{~cm}$ x $6 \mathrm{~cm}$ com $6 \mathrm{~cm}$ de altura, extraídos de painéis projetados.

ii) Análise experimental de vigas $\mathrm{T}$, formadas por elementos tipo sanduíche, para verificação da ligação entre esses elementos;

iii) Análise experimental de painéis tipo sanduíche, com placas resistentes conectadas por nervuras, submetidas a esforços de flexão ou de compressão; 
iv) Análise dos resultados obtidos nos ensaios realizados, visando compreender melhor o comportamento estrutural de elementos tipo sanduíche e definir procedimentos mais adequados para o cálculo dessas estruturas.

\subsection{CONTEÚDO DO TRABALHO}

Nos itens anteriores deste capítulo foram apresentados a importância do tema e os objetivos do trabalho.

No capítulo 2 consideram-se: o estado da arte de estruturas mistas tipo sanduíche, enfocando principalmente métodos construtivos que utilizam pré-painéis com posterior projeção da argamassa; os principais tipos de conectores utilizados, classificando-os em função da finalidade do elemento sanduíche; definições, notas históricas e resultados da pesquisa bibliográfica realizada. São também discutidos critérios para projeto, análise e construção de estruturas tipo sanduíche.

No capítulo 3 são feitas algumas considerações sobre: comportamento estrutural de estruturas tipo sanduíche, cálculo para solicitações de flexão e para tensões geradas por variações volumétricas e, ainda, vários ensaios realizados em elementos tipo sanduíche, encontrados na literatura.

No capítulo 4 são tratados: argamassa ou microconcreto projetado, histórico da utilização do concreto projetado, suas propriedades, materiais constituintes, técnicas de projeção e controle de qualidade, dosagem de argamassas e de microconcretos e procedimentos mais utilizados.

No capítulo 5 são apresentados: estudo sobre a resistência de argamassa projetada, relação entre a resistência à compressão de pastilhas extraídas de placas projetadas e a resistência de corpos-de-prova cilíndricos de $10 \mathrm{~cm}$ x $20 \mathrm{~cm}$. Os resultados sobre dosagem e resistência da argamassa projetada auxiliaram em muito na execução e na análise dos resultados de ensaios de elementos tipo sanduíche.

No capítulo 6 estão detalhados: os ensaios realizados em vigas $\mathrm{T}$ e toda a metodologia de ensaio, desde descrição e execução dos modelos, materiais utilizados, esquemas estáticos, aparatos de ensaio até resultados obtidos e sua análise. Descrevem-se os ensaios à flexão em vigas T compostas por elementos tipo sanduíche, onde se observou principalmente a ligação mesa-alma. 
O capítulo 7 trata de ensaios à flexão em painéis tipo sanduíche, onde se verificou a influência das nervuras no comportamento estrutural. Da análise dos resultados pôde-se tirar alguns parâmetros para o cálculo desses elementos.

No capítulo 8 apresentam-se as conclusões obtidas com relação ao potencial de estruturas tipo sanduíche a ser explorado em obras de infra-estrutura, ao comportamento estrutural desses elementos e aos critérios que se julgam mais importantes, para que se possam projetar e construir tanto edificações como muros de arrimo, canais de drenagem, galerias e reservatórios, com base nas análises feitas ao longo desse trabalho. Sugerem-se ainda neste capítulo vários temas para a continuidade da pesquisa. 


\section{ESTRUTURAS MISTAS TIPO SANDUÍCHE}

$\mathrm{Na}$ construção de edificações, a busca por elementos de vedação que proporcionassem bom isolamento térmico e boa durabilidade conduziram à concepção de painéis tipo sanduíche. Mais tarde, esses painéis passaram a assumir, também, função estrutural.

Uma estrutura mista tipo sanduíche é composta por duas ou mais camadas de materiais diferentes, fazendo com que o conjunto ganhe em termos estruturais. A principal característica é a obtenção de elementos com maior rigidez, conseguida com o afastamento das faces resistentes. Pode-se conseguir, ainda, estruturas mais leves, quando se utilizam camadas intermediárias constituídas de materiais como o EPS ou o poliuretano expandido.

Em edificações, são muito utilizados painéis tipo sanduíche com faces de concreto ou argamassa, podendo ser portantes ou não, servindo ainda para o isolamento termo-acústico e para vedação. Em relação a painéis de mesma espessura total, em geral, o peso próprio é menor com a presença do núcleo isolante. São usados como divisórias internas ou externas e podem ser facilmente acoplados a diversos tipos de elementos, tais como estruturas metálicas, estruturas de concreto (pré-moldado ou não), alvenarias etc.

Os painéis sanduíche podem ser pré-moldados ou moldados no local da obra. Neste capítulo será dada ênfase a painéis moldados no local da obra. 


\section{$2.1 \quad$ TIPOLOGIA}

Uma estrutura sanduíche é representada de maneira esquemática na fig.2.1

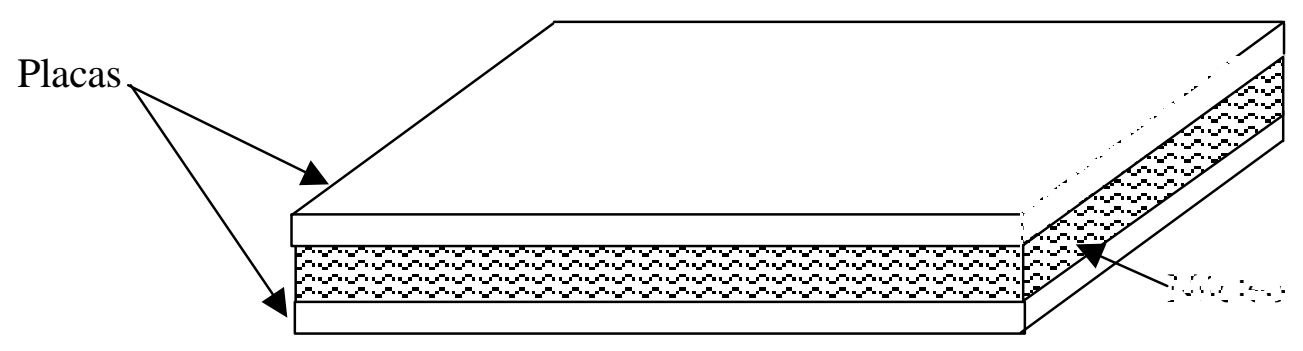

FIGURA 2.1 - CONSTITUINTES DE UM ELEMENTO TIPO SANDUÍCHE

O material das placas resistentes pode ser madeira, amianto, fibra de vidro, alumínio, chapas de aço, concreto, argamassa, entre outros.

O material do núcleo pode ser EPS, poliuretano expandido, materiais reciclados de rejeitos industriais, concreto celular, gesso, papelão etc. Em geral, quando o núcleo não é responsável pela transferência de esforços entre as placas, a exigência mínima para constituição do núcleo é que este seja leve (comparável a uma placa de EPS) e tenha rigidez suficiente para a montagem do elemento sanduíche.

Núcleos leves facilitam o transporte. Porém, a leveza não constitui conditio sine qua non para a escolha do material de núcleo. Para o sistema com posterior execução das faces de argamassa, se fosse utilizada alvenaria de tijolos como núcleo, este material poderia atender plenamente às exigências. No entanto, não é leve, quando comparado com uma placa de EPS, por exemplo. Essa escolha é função também da finalidade da estrutura, da viabilidade e da disponibilidade de material do núcleo.

Placas de argamassa ou de concreto podem ser ligadas por conectores de diversos tipos. O núcleo pode ou não participar da transferência de esforços. Quando não há participação do núcleo, a transferência de esforços fica por conta dos conectores. Mais detalhes serão vistos no item seguinte. 


\subsection{CONECTORES}

As faces resistentes do painel sanduíche podem ser ligadas através de conectores, para manter o painel geometricamente estável durante o manuseio (confecção, transporte, armazenamento, montagem etc.) e em boas condições de funcionalidade após a conclusão da obra. Esses conectores atravessam o núcleo, mantendo-o firme no lugar, e são fixados em cada face, impedindo sua separação. O PCI (1997) observa que os conectores típicos possuem espaçamentos que variam entre $406 \mathrm{~mm}$ x $406 \mathrm{~mm}$ e $1219 \mathrm{~mm}$ x $1219 \mathrm{~mm}$.

Os conectores podem ser de concreto, aço ou plástico. Atendem a uma variedade de funções. Se o painel é pré-moldado e posteriormente serrado em tamanhos padrões, os conectores devem ser capazes de resistir às tensões criadas entre as placas, durante o corte dos painéis. Os conectores servem também para transferir as ações de vento (ou sismos, em alguns casos) de uma placa para outra. Em painéis com composição total, os conectores proporcionam resistência do conjunto à flexão e ao cisalhamento. Em painéis não-compostos, os tipos de arranjo de conectores são detalhados para minimizar a transferência de cisalhamento, de maneira que as placas possam agir independentemente.

Em vários casos de estruturas tipo sanduíche, é o núcleo que garante a maior parte da transferência de esforços, ficando os conectores com a função construtiva e de manter as placas interligadas. Estudos realizados por HANAI \& TAKEYA (1994) em painéis com núcleo de EPS e faces de argamassa projetada, conectadas por fios soldados nas telas de aço de cada face, comprovam que os conectores não oferecem contribuição significativa ao cisalhamento, sendo provável que o grau de contribuição seja decorrente só da aderência do núcleo com as faces resistentes.

Podem-se encontrar várias combinações de conectores. Por exemplo, em painéis com composição total, blocos de concreto podem ser utilizados como mecanismos de transferência, e conectores tipo C podem ser utilizados para prevenir a separação das placas.

FONSÊCA (1994) classificou os conectores segundo a capacidade de transmissão do cisalhamento entre as placas, conforme o esquema: 


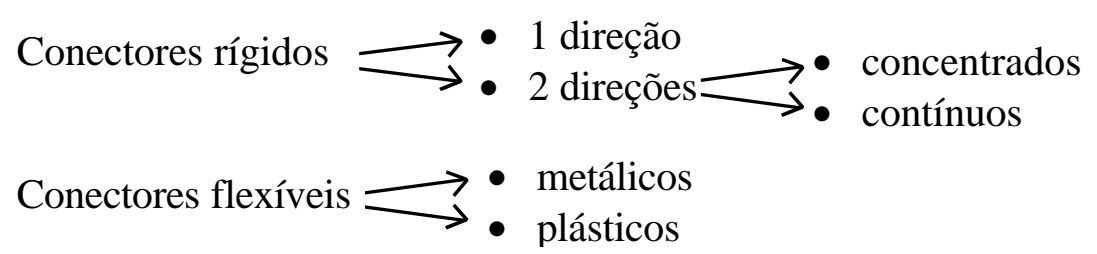

\subsubsection{Conectores rígidos}

As nervuras de concreto, mostradas na fig.2.2, promovem uma melhoria no comportamento estrutural, quando comparadas com conectores metálicos, mas reduzem a eficiência térmica do painel, devido à menor área disponível de isolante (núcleo). A distribuição ou a localização das nervuras são os pontos-chave para não haver perda excessiva de isolamento térmico, nos casos em que esta característica é importante.

Dos ensaios realizados por BANSULBUL \& AL-SULAIMANI (1991), somente com painéis nervurados, concluiu-se que o número de nervuras e suas respectivas taxas de armadura são muito importantes para se obter composição total. Entretanto, aumentando-se além do necessário o número de nervuras e a taxa de armadura, não há melhora significativa no comportamento do painel à flexão em nenhum dos três estádios (I, II e III). Portanto, um estudo acerca do número de nervuras e da quantidade de armadura, para certo tipo de painel, é muito importante do ponto de vista econômico, pois impede exageros e desperdícios de materiais que não contribuem para a capacidade resistente do painel.
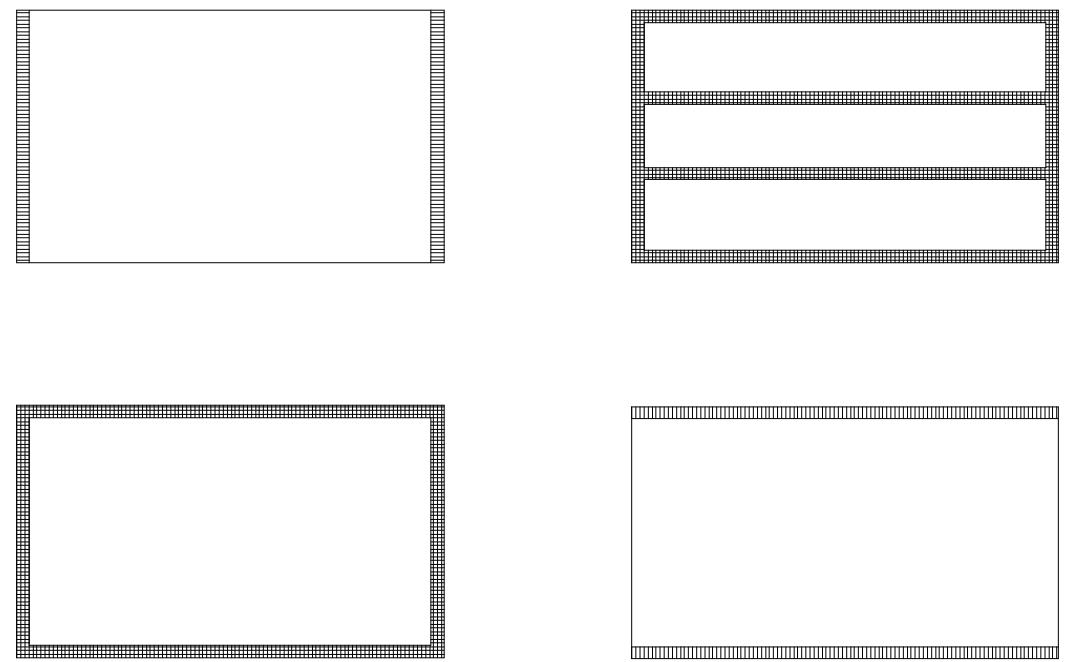

FIGURA 2.2 - NERVURAS DE CONCRETO (FONSÊCA, 1994) 
Os conectores rígidos (shear conectors) são utilizados para transferir forças cortantes de uma placa para outra. Em alguns casos, conectores rígidos podem ser utilizados para transferir o peso da placa não estrutural para a placa estrutural.

Alguns conectores são rígidos em uma direção e flexíveis na outra, sendo chamados conectores rígidos em uma direção. Além dos formados por nervuras de concreto em uma só direção, outros exemplos desses conectores, indicados na fig.2.3, são aqueles formados por barras dobradas, luvas planas, chapas de metal expandidas e barras contínuas nas formas de treliças metálicas, barras dobradas e placas metálicas expandidas. Cuidados devem ser tomados no processo de fabricação, para manter a orientação correta dos conectores.
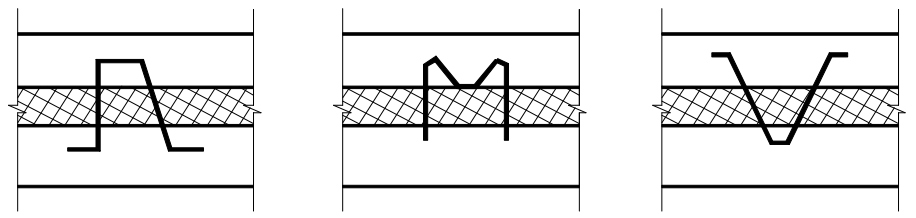

Configurações de barras dobradas como conector rígido concentrado
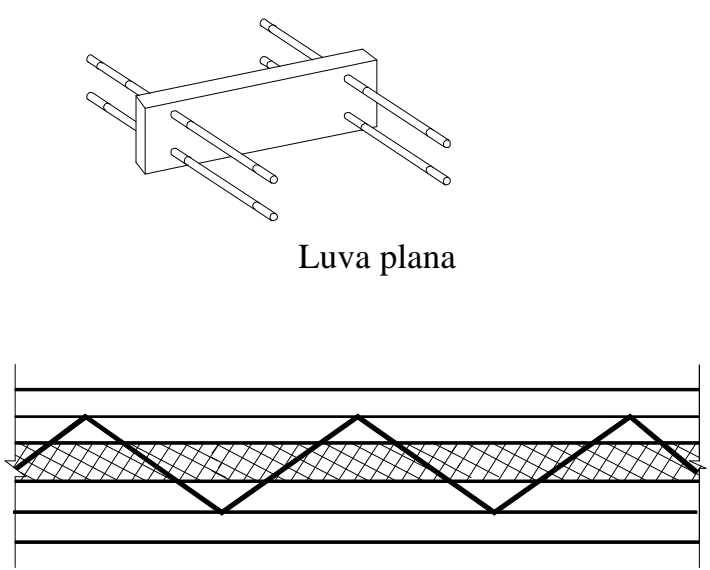

Treliça metálica

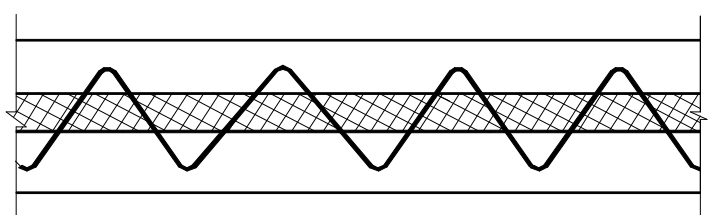

Barras dobradas contínuas

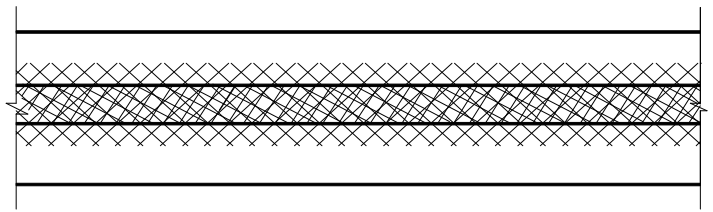

Placa de metal expandida

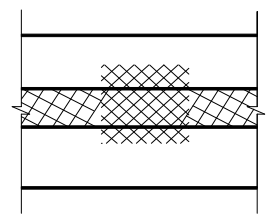

Chapa de metal expandida
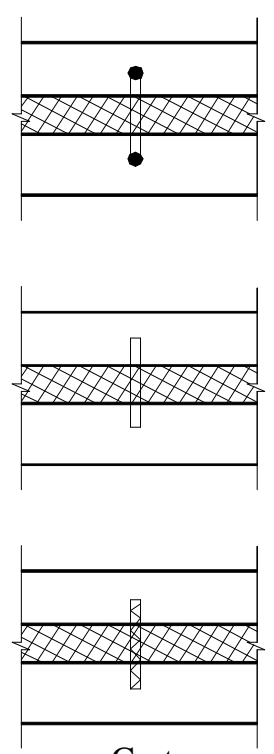

Corte

FIGURA 2.3 - CONECTORES RÍGIDOS EM UMA DIREÇÃO (PCI, 1997) 
Outros conectores são rígidos nas duas direções e, conseqüentemente, transferem as forças cortantes longitudinais e transversais, ao longo dos vãos do painel. Alguns são localizados em pontos dispersos, como as luvas cilíndricas, as âncoras tipo coroa e os blocos de concreto (figuras 2.4 e 2.5). Outros são formados por treliças espaciais, como a mostrada na fig. 2.4.

As características desses conectores podem ser obtidas nos catálogos dos fabricantes. Quando são utilizados blocos de concreto ou nervuras, geralmente é utilizado o valor da resistência última do concreto ao cisalhamento.

Os blocos de concreto, mostrados na fig.2.5, constituem pontos de ligação rígida entre as duas placas. São moldados por meio de pequenos vazios deixados no isolante, que são preenchidos durante o processo de moldagem de uma das placas. As posições dos blocos são excelentes locais para posicionar as alças, necessárias para o manuseio dos painéis pré-moldados.

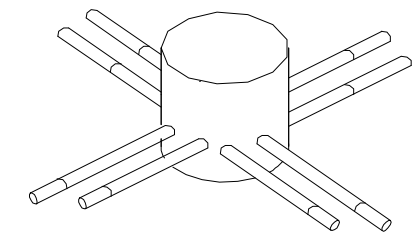

Luva cilíndrica

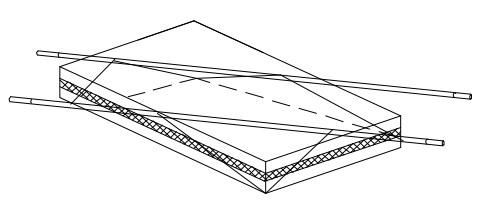

Conector de barra espacial

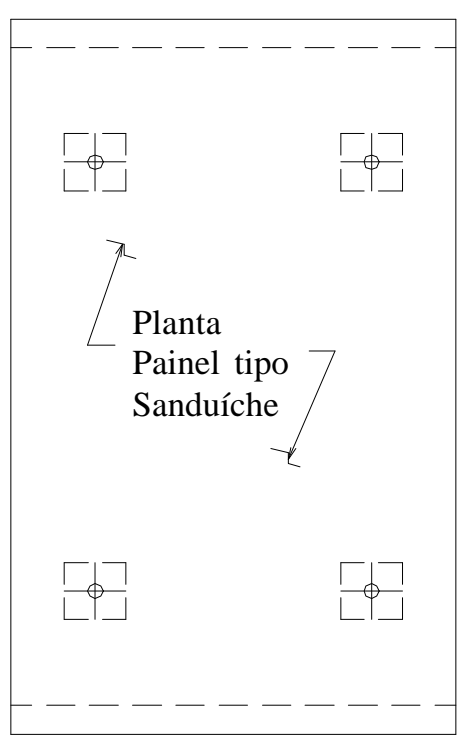

Seção AA

\section{FIGURA 2.4 - CONECTORES RÍGIDOS EM DUAS DIREÇÕES (PCI COMMITTEE REPORT, 1997)}

PFEIFER \& HANSON (1965) realizaram ensaios com a finalidade de analisar o uso de alguns tipos de conectores. Foram estudadas diversas disposições de nervuras e de blocos de concreto, para se chegar a uma eficiência estrutural máxima com a mínima perda de isolamento. $\mathrm{O}$ uso de pequenos blocos de concreto 
distribuídos uniformemente ao longo da superfície do painel parece ser uma forma bastante eficiente de conexão entre as placas.
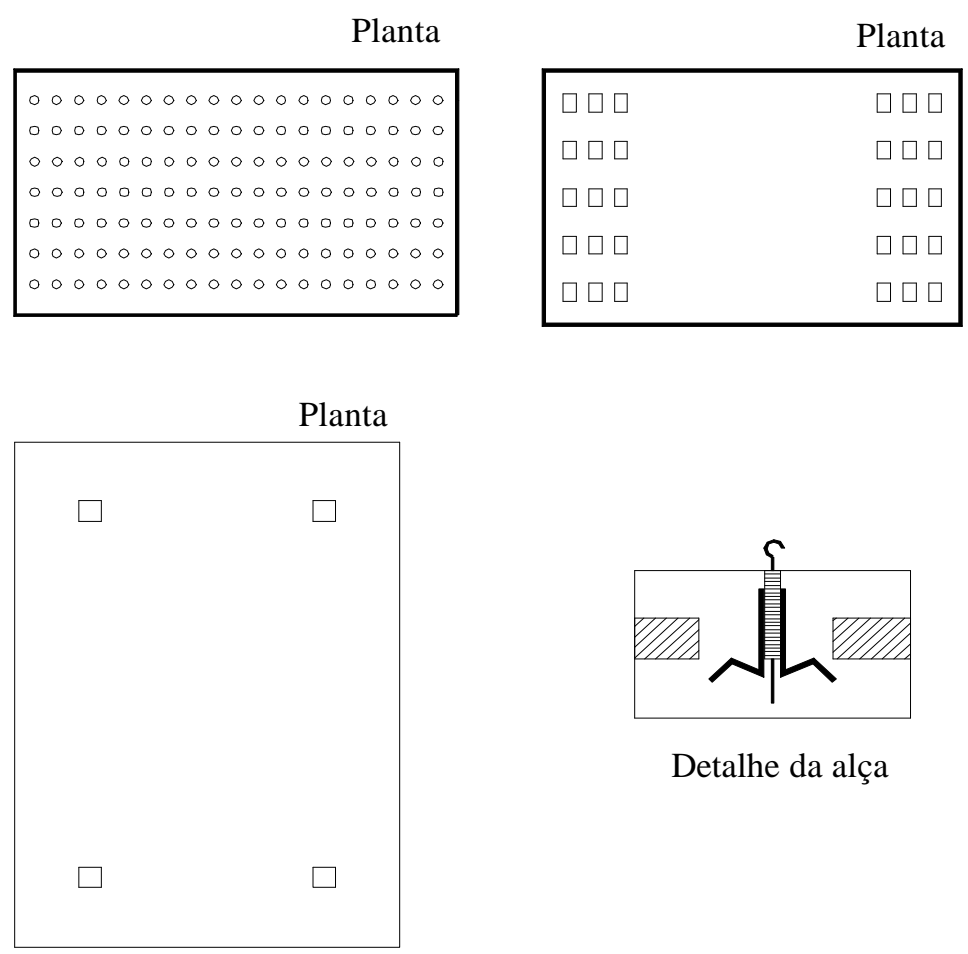

FIGURA 2.5 - BLOCOS DE CONCRETO (PFEIFER \& HANSON, 1965)

Em alguns casos, o núcleo pode proporcionar uma resistência transversal entre as placas. Núcleos com faces rugosas e espessas transferem mais cisalhamento do que isolantes com faces lisas. Em núcleos colados nas placas, a resistência transversal é considerada temporária. Em painéis pré-moldados não-compostos, supõe-se que o núcleo proporcione transferência de cisalhamento suficiente para criar uma ação composta durante a confecção, o manuseio e a montagem, mas a transferência não é garantida para as condições do painel em serviço.

\subsubsection{Conectores flexíveis}

Os conectores flexíveis (non-shear conectors) são capazes de resistir a esforços de compressão e de tração, mas resistem apenas uma parcela insignificante de força cortante. Conseqüentemente, é desprezada qualquer contribuição para a composição do painel.

Eles são empregados em painéis não-compostos, para transferir forças normais entre as placas. Nos painéis completamente compostos, os conectores 
flexíveis podem ser utilizados para auxiliar os conectores rígidos, quando é grande o espaçamento entre estes.

Exemplos de conectores flexíveis são os pinos metálicos, os plásticos, os de fibra de vidro e as treliças deformáveis, como mostra a fig.2.6.
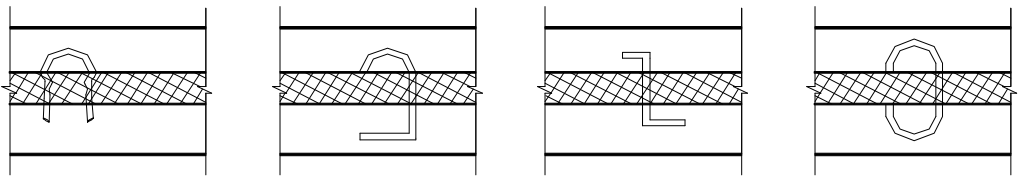

Conectores de pinos metálicos

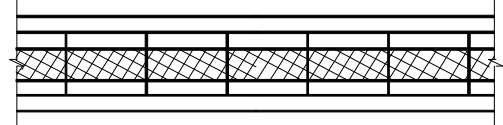

Treliça deformável
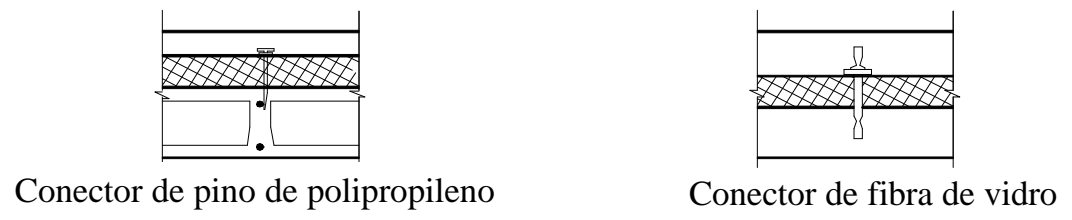

FIGURA 2.6 - CONECTORES FLEXÍVEIS (PCI, 1997)

\subsubsection{Recomendações sobre os conectores}

A disposição, a quantidade e o espaçamento dos conectores variam de acordo com o grau de composição desejado. Para uma melhor eficiência do painel quando sujeito à flexão, algumas recomendações de ordem prática, feitas pelo PCI (1992), já são utilizadas por diversos construtores. São elas:

i) O espaçamento dos conectores flexíveis, medidos de eixo a eixo, deve ser preferencialmente em torno de $60 \mathrm{~cm}$ e de forma alguma superar $120 \mathrm{~cm}$; não se deve usar menos que dois conectores por metro quadrado de área do painel (fig.2.7);

ii) No perímetro do painel e em torno de aberturas maiores que $60 \mathrm{~cm}$, deve-se limitar a $60 \mathrm{~cm}$ o espaçamento entre os conectores (fig.2.7);

iii) Deve-se usar uma combinação de conectores rígidos complementada com conectores flexíveis, com a finalidade de evitar que as placas se separem 
durante a ação de vento e no processo de desforma, para o caso de prémoldados (fig.2.7);

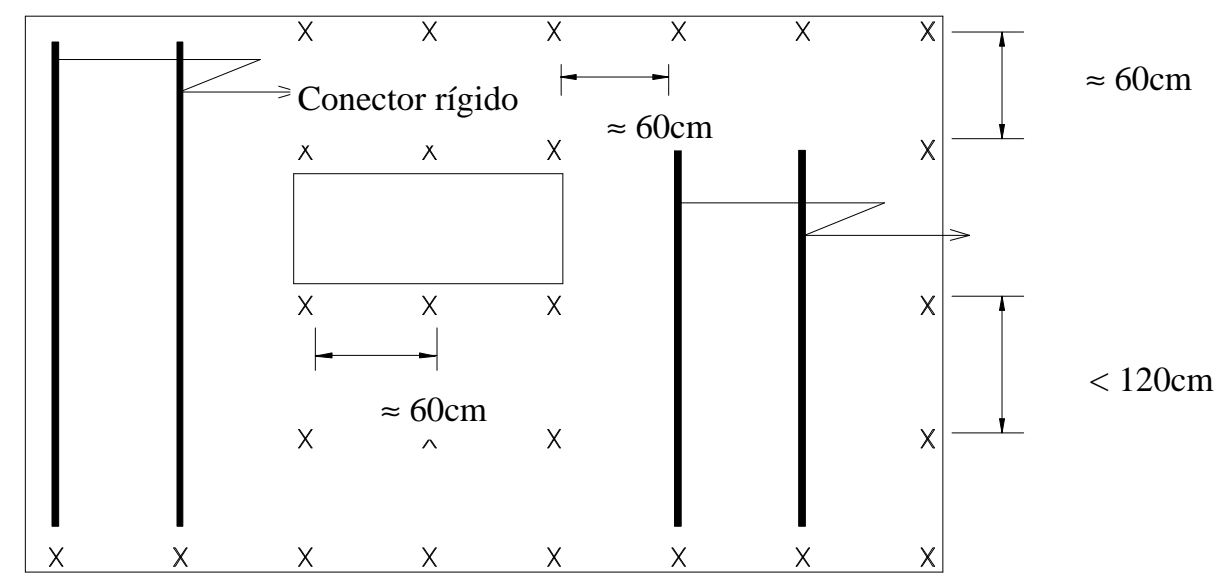

FIGURA 2.7 - DISPOSIÇÃO DOS CONECTORES FLEXÍVEIS ( $\mathbf{x}$ = CONECTORES FLEXÍVEIS)

iv) Em painéis tipo $\Pi$ não-compostos é recomendado o uso de uma luva cilíndrica em uma das nervuras e uma luva plana com a mesma resistência ao cisalhamento vertical na outra nervura, no mesmo nível horizontal (fig.2.8);

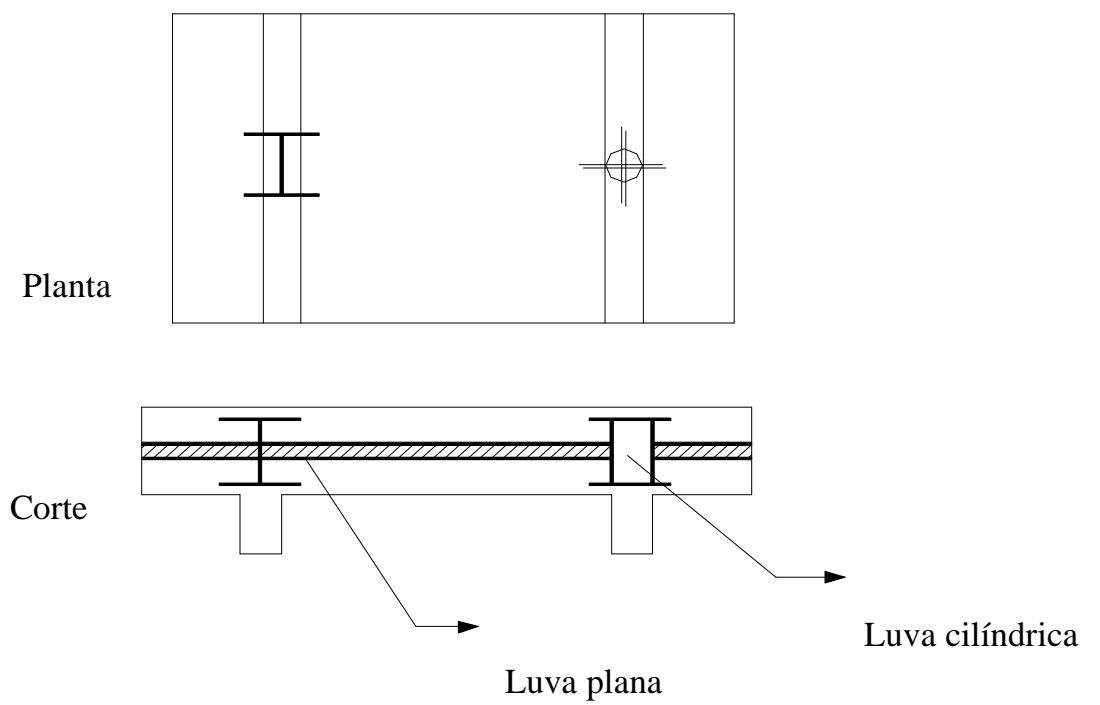

FIGURA 2.8 - DisPoSIÇÃO DOS CONECTORES EM PAINÉIS NERVURADOS NÃOCOMPOSTOS

v) Em painéis não-compostos, o conector rígido em duas direções que liga a placa não-estrutural à placa estrutural deve ser um único elemento, situado o mais próximo possível do centro de gravidade do painel (fig.2.9). Agindo assim, as 
tensões provenientes da variação de volume serão minimizadas ou evitadas, pois a placa não-estrutural possuirá liberdade de movimentos;

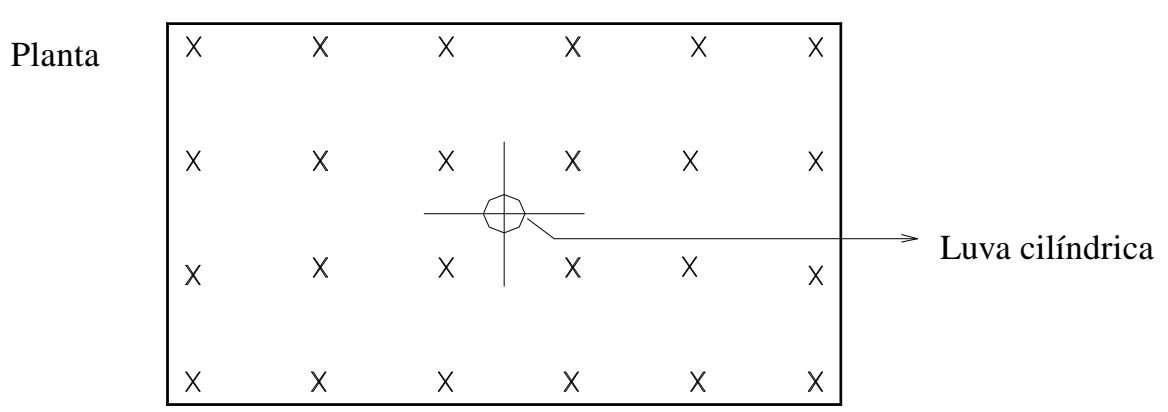

FIGURA 2.9 - DISPOSIÇÃO DO CONECTOR RÍGIDO EM DUAS DIREÇÕES PARA PAINÉIS NÃO-COMPOSTOS ( $\mathbf{X}=$ CONECTORES FLEXÍVEIS)

vi) Conectores rígidos em uma direção também podem ser empregados em painéis não-compostos, orientados ao longo dos eixos perpendiculares principais do painel. Dessa forma restringem-se o cisalhamento e uma parcela do momento de torção, sem impedir o funcionamento não-composto entre as placas (fig.2.10).

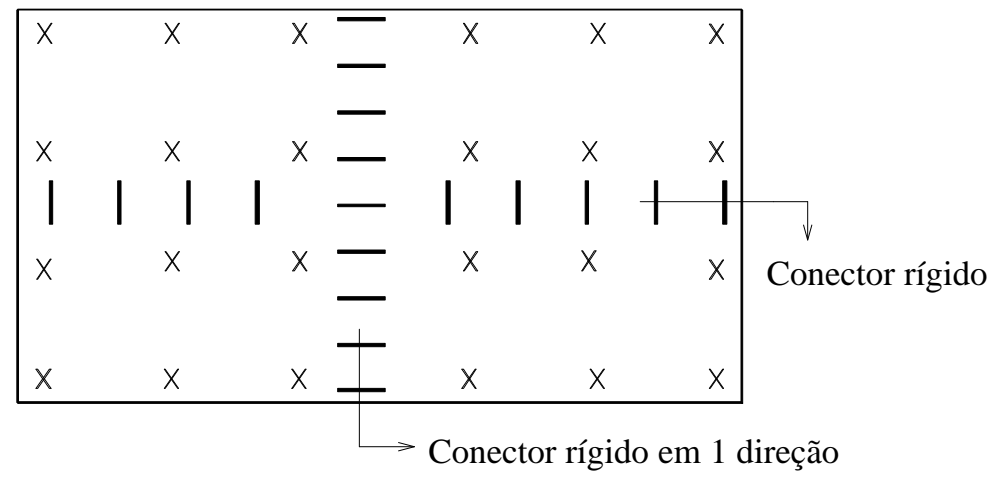

FIGURA 2.10 - DISPOSIÇÃO DE CONECTORES RÍGIDOS EM UMA DIREÇÃO PARA PAINÉIS NÃO-COMPOSTOS ( $\mathbf{X}=$ CONECTORES FLEXÍVEIS $)$

\subsection{MÉTODO CONSTRUTIVO COM FACES MOLDADAS NO LOCAL}

Estruturas mistas tipo sanduíche com núcleo de EPS e placas de argamassa moldadas no local da obra têm sido utilizadas como elementos na construção de edificações, conseguindo-se estruturas com bom desempenho estrutural e competitivas com relação a outros tipos tradicionais de construção. 
Painéis sanduíche com moldagem no local da obra consistem de pré-painéis formados, em geral, por placas de poliestireno ou poliuretano expandido (núcleo), nas faces das quais são colocadas telas soldadas (reforço estrutural do painel). Essas telas são ligadas entre si por meio de fios que atravessam a placa do núcleo (fig.2.11).

Os pré-painéis podem ser feitos em fábrica manualmente ou através de equipamentos sofisticados, e então são levados à obra e montados para execução de paredes exteriores, paredes interiores, forros e telhados.

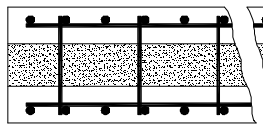

Planta
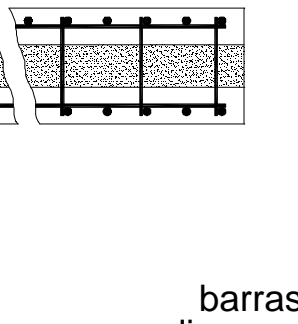

barras diagonais

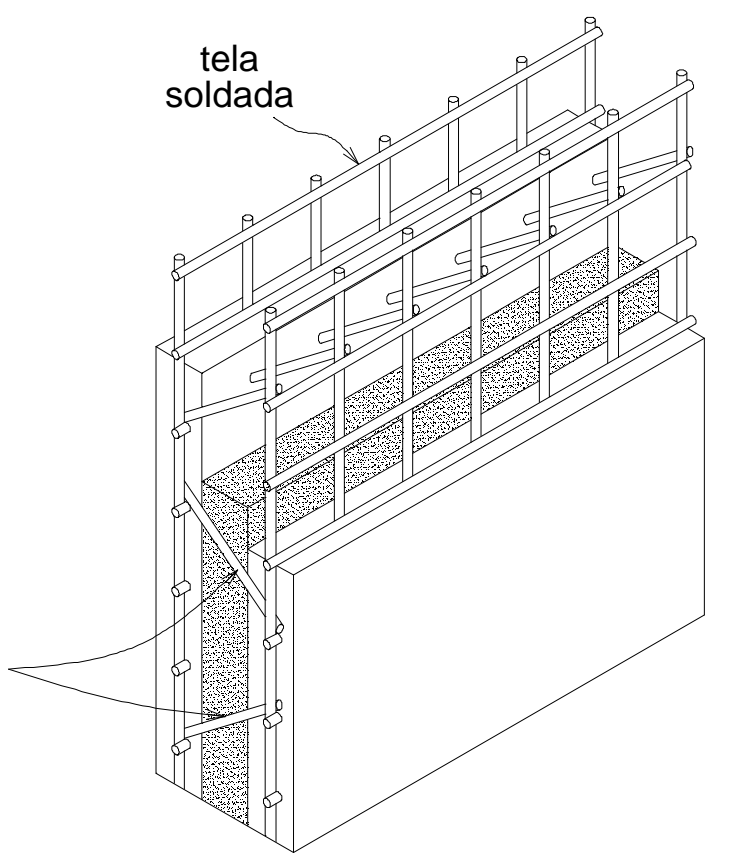

\section{FIGURA 2.11 - PRÉ-PAINEL DE POLIESTIRENO COM ARMADURA}

Os pré-painéis são produzidos em tamanhos padronizados e saem da fábrica com as dimensões e os detalhes necessários para que possam ser executados na obra.

Em cada painel, as larguras das telas soldadas ultrapassam em $15 \mathrm{~cm}$ a largura do EPS, proporcionando a emenda de um painel com o consecutivo. Somente quando todos os painéis são conectados e colocados na posição correta é que recebem um revestimento de argamassa, que varia de $2,5 \mathrm{~cm}$ a $3,8 \mathrm{~cm}$ de espessura, de cada lado do núcleo. Esse revestimento é feito por meios tradicionais de emboçamento ou por processos mais modernos, que empregam mecanismos de jateamento de argamassa sob pressão, resultando um painel rígido e uma estrutura 
monolítica, sem juntas. Maiores detalhes sobre argamassas projetadas estão no capítulo 4 .

Em vários países existem patentes relativas à técnica de execução de painéis sanduíche com moldagem posterior das placas resistentes de argamassa, como, por exemplo, Cabrini Monolite, Polywall, W-Panel, Insteel e Isolite. Estes sistemas se diferenciam pela disposição da armadura, pela forma de ligação das telas soldadas (ângulo do fio de ligação com o plano da tela soldada), pelo tipo e espessura do núcleo, pela espessura da capa resistente e pelas dimensões dos pré-painéis.

A tabela 2.1, retirada de PICKARD (1990), indica características particulares de alguns fabricantes que produzem painéis, utilizando-se este sistema nos Estados Unidos.

TABELA 2.1 - Especificações dos painéis utilizados nos E.U.A.

\begin{tabular}{c|c|c|c|c|c}
\hline Tipo & $\begin{array}{c}\text { Espessura total } \\
(\mathrm{mm})\end{array}$ & $\begin{array}{c}\text { Largura } \\
(\mathrm{mm})\end{array}$ & $\begin{array}{c}\text { Altura } \\
(\mathrm{mm})\end{array}$ & $\begin{array}{c}\text { Tipo de } \\
\text { isolante }\end{array}$ & $\begin{array}{c}\text { Espessura do } \\
\text { isolante }(\mathrm{mm})\end{array}$ \\
\hline $\mathrm{A}$ & $76,2 / 101,6 / 127 / 152,4$ & 1220 & $1830-12190$ & Poliuretano & $12,7 / 114,3$ \\
\hline $\mathrm{B}$ & $76,2 / 101,6$ & 1220 & $2440-7315$ & Poliestireno & $50,8 / 76,2$ \\
\hline $\mathrm{C}$ & $50,8 / 76,2$ & 1220 & $1830-4880$ & Poliuretano & $12,7 / 50,8$ \\
\hline $\mathrm{D}$ & 76,2 & 1220 & 2440 & Poliestireno & 57,2 \\
\hline
\end{tabular}

PICKARD (1990) enumera algumas aplicações desses elementos com argamassagem das faces na obra, como, por exemplo: piscinas, residências, abrigos e alojamentos militares, painéis estruturais, escolas, hospitais, silos graneleiros, paredes de contenção, muros e reforços de túneis.

\subsubsection{Armadura}

As armaduras utilizadas nesses painéis são do mesmo tipo que as usadas em elementos tradicionais de concreto ou argamassa, ou seja, telas soldadas e barras de aço de pequeno diâmetro.

Segundo os resultados apresentados por BANSULBUL e AL-SULAIMANI (1991), podem ser feitos alguns comentários sobre as armaduras em painéis tipo sanduíche:

i) O número de camadas de telas não apresenta influência significativa na rigidez do painel no Estádio I, mas apresenta bons resultados no Estádio II; 
ii) O uso de armadura complementar à tela soldada (armadura de esqueleto) parece melhorar as características elásticas do painel, bem como seu comportamento após as primeiras fissuras;

iii) Aumentando-se o número de camadas de telas e usando-se armadura de esqueleto na placa tracionada, é possível aumentar a ductilidade e a resistência última do painel.

\subsubsection{Núcleo}

Do ponto de vista estrutural, o tipo de núcleo apresenta maior importância quando se trabalha com elementos tipo sanduíche sem conectores, e isso pelo efeito da aderência. À medida que se utilizam conectores mais eficientes, a importância do núcleo limita-se apenas à sua eficiência térmica, no caso de edificações.

Às vezes pode ser mais importante obter-se o máximo de isolamento térmico, independentemente do peso próprio ou do custo final. No caso de câmaras frigoríficas, um bom isolamento térmico proporciona maior economia de energia e o investimento inicial pode ser recuperado com folga, em decorrência dessa economia de energia.

SPOSTO(1995) apud ABIT, enumera alguns isolantes térmicos mais conhecidos no mercado mundial, os quais são enumerados a seguir:

- amianto prensado;

- amianto projetado;

- argila expandida;

- carbonato de magnésio;

- cimentos isolantes;

- concreto celular;

- cortiça aglomerada;

- ebonite expandida;

- espuma de borracha;

- espuma de vidro;

- espuma de poliuretano;

- espuma de uréia formadeído;

- feltros;

- fibras de madeira prensadas;

- lã de escórias;

- lã de vidro;

- lãs isolantes refratárias;

- massas isolantes;

- multifoliados metálicos;

- papelão ondulado;

- perlita expandida; 
- poliestireno expandido;

- poliestireno extrudado;

- PVC expandido;

- sílica diatomácea;

- sílica expandida;

- silicato de cálcio;

- vermiculite expandido.

Muitos desses materiais não são fabricados no Brasil, e outros ainda estão em fase de experiência. Ainda outro material que pode ser utilizado como núcleo isolante é a palha de arroz, por possuir baixo custo (referente ao transporte de regiões beneficiadoras próximas de onde será utilizada), sendo, inclusive, considerada como um resíduo.

Para residências em climas não tão rigorosos, não é necessário um isolamento térmico muito eficiente, e sim um custo mais acessível. Nesses casos é mais importante tirar proveito das características estruturais do painel.

A eficiência estrutural depende da associação de conectores, nervuras e núcleos, que juntos forneçam a composição necessária ao elemento tipo sanduíche. Há vários casos em que não há necessidade de isolamento térmico e acústico, como, por exemplo, em muros de arrimo, reservatórios de água e galerias, entre outros. Os núcleos, para esses casos, não precisam necessariamente ser leves como o EPS, e as placas podem ser interligadas por nervuras de argamassa, com ou sem armadura.

\subsubsection{Tipos de estruturas}

A principal aplicação do sistema construtivo tipo sanduíche é encontrada na construção de edificações residenciais, comerciais e industriais. Além da segurança estrutural, esses tipos de construção geralmente exigem conforto térmico e acústico, necessitando de núcleos que atendam a essas finalidades. O sistema construtivo permite a criação de formas variadas, dando uma flexibilidade arquitetônica muito grande.

Nas figuras 2.12 a 2.17 são mostradas algumas obras realizadas com painéis tipo sanduíche, com execução posterior das faces resistentes. Os pré-painéis de EPS são montados no local da obra, onde recebem um revestimento de argamassa, projetada por meio de caneca de projeção ou manualmente, utilizando-se colher de pedreiro. 


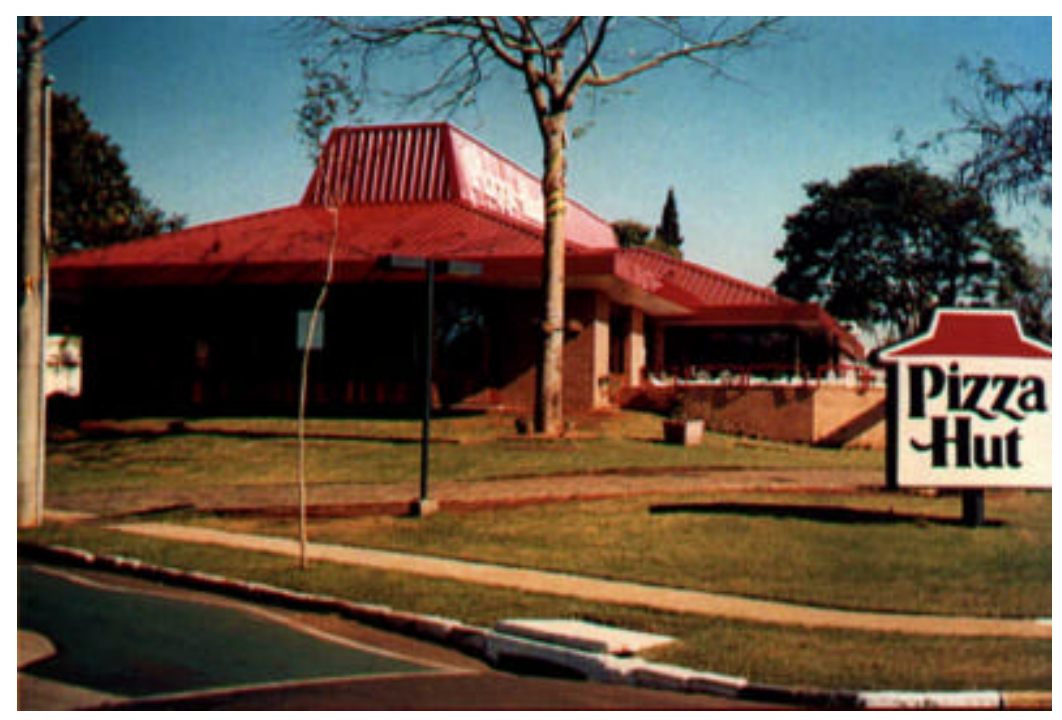

FIGURA 2.12 - PIZZA HUT - RIBEIRÃO PRETO - SP

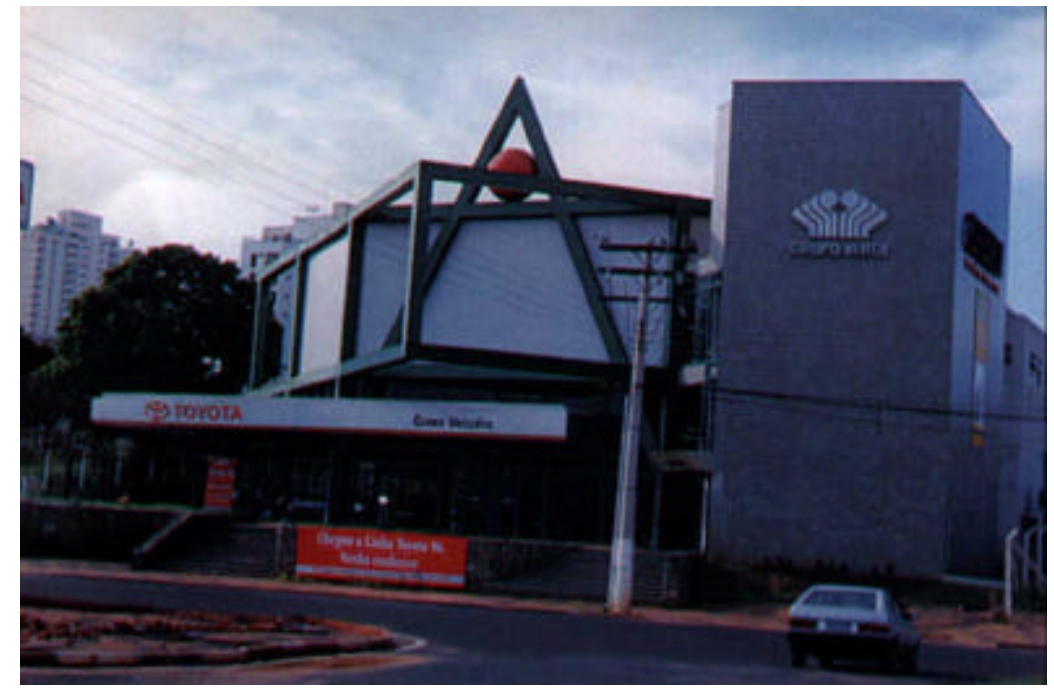

FIGURA 2.13 - TOYOTA - SÃO JOSÉ DO RIO PRETO - SP

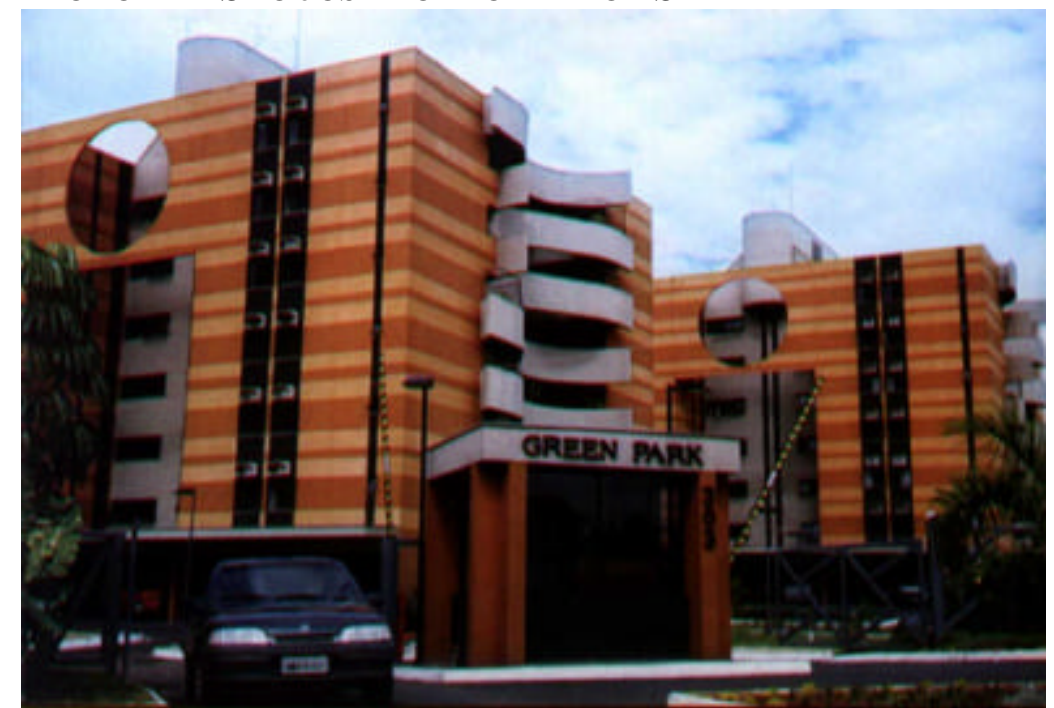

FIGURA 2.14 - CONDOMÍNIO GREEN PARK - SÃO JOSÉ DO RIO PRETO - SP 


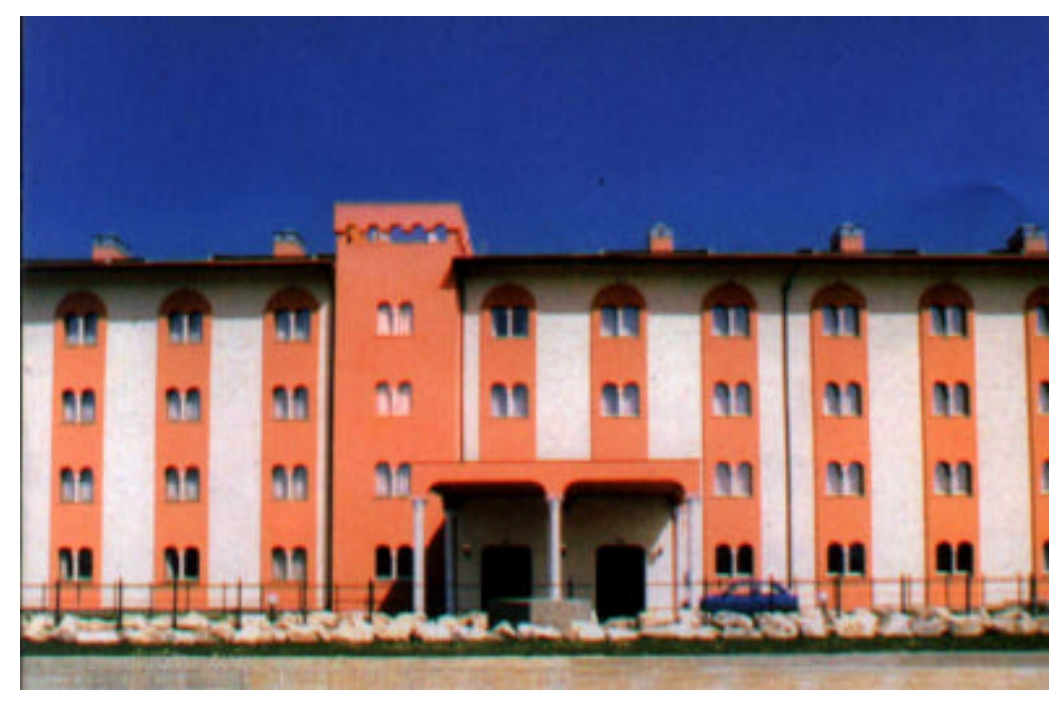

FIGURA 2.15 - HOTEL - ITÁLIA

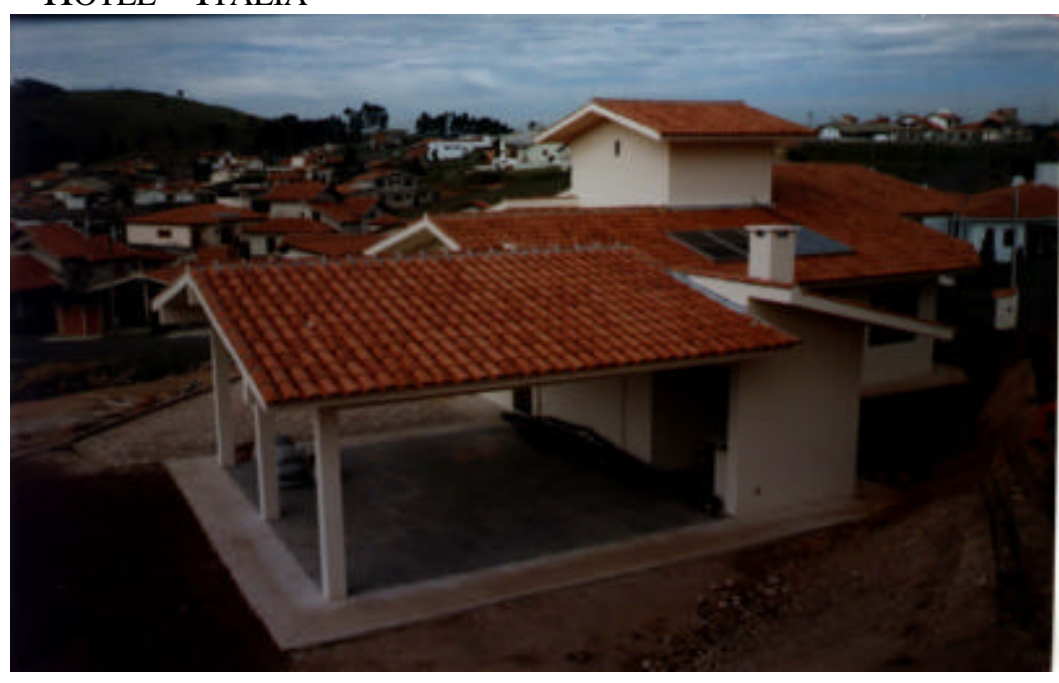

FIGURA 2.16 - CONDOMÍNIO SANTO ANTÔNIO - ITU - SP

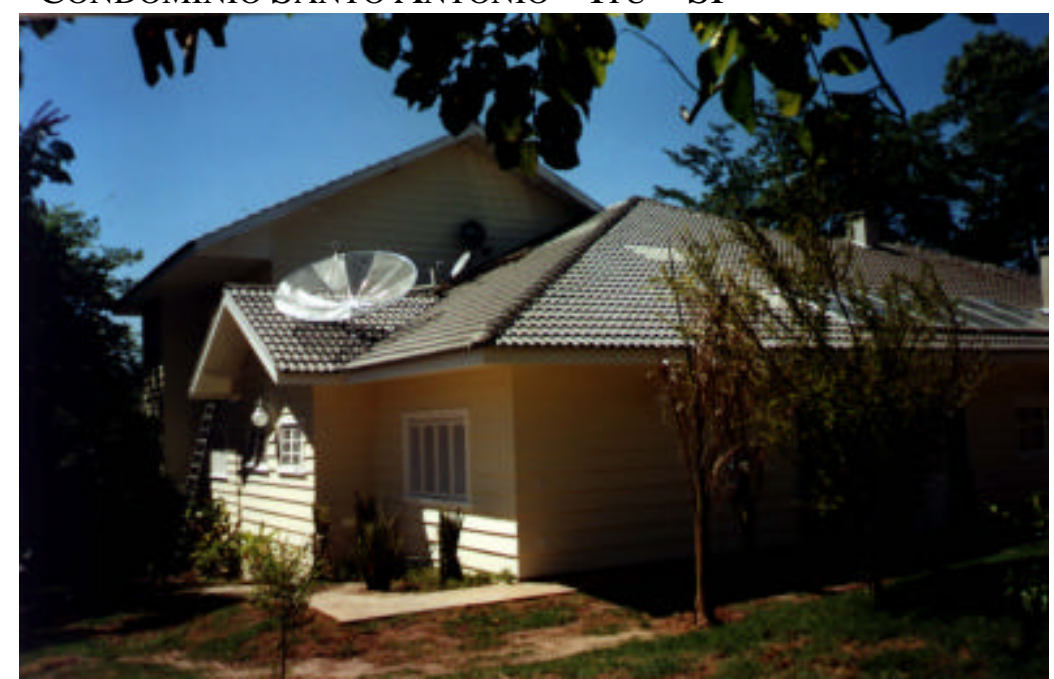

FIGURA 2.17 - CONDOMÍNIO TERRAS DE SÃO JoSÉ - ITU - SP 
Observam-se nessas figuras as várias possibilidades arquitetônicas em edificações, possibilitadas pela liberdade de forma inerente ao sistema.

O processo executivo de construção tipo sanduíche é aplicado ainda em coberturas em cascas, com curvaturas simples ou dupla, como pode ser visto nas figuras 2.18 a 2.20. O processo construtivo foi desenvolvido por TEXEIRA (1999). Os protótipos construídos pelo autor foram executados com argamassa projetada por meio de máquinas de projeção, eliminado-se totalmente o uso de fôrmas.

(1) COLOCAĊÃO DAS CAMBOTAS
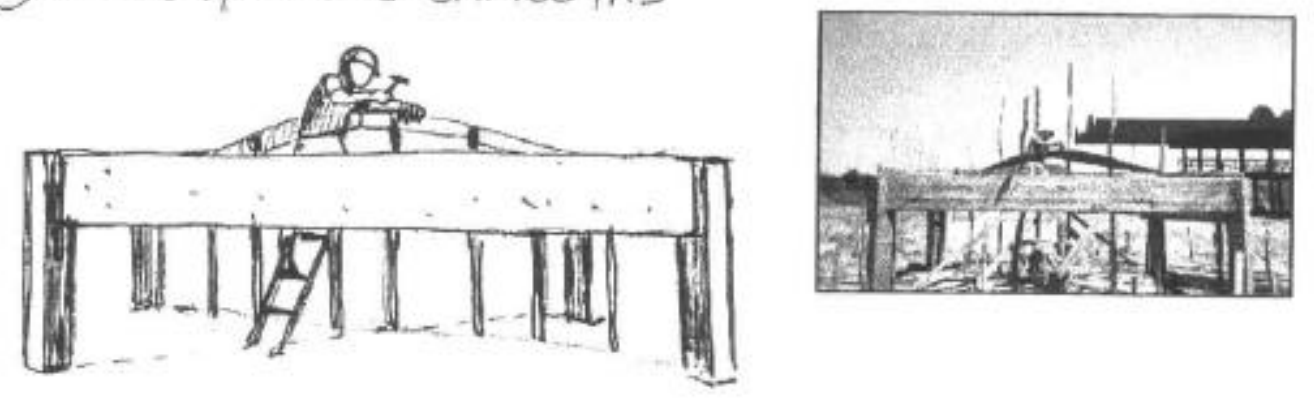

(2) COLOCACYÃO

DAS TELAS

E DO EPS.
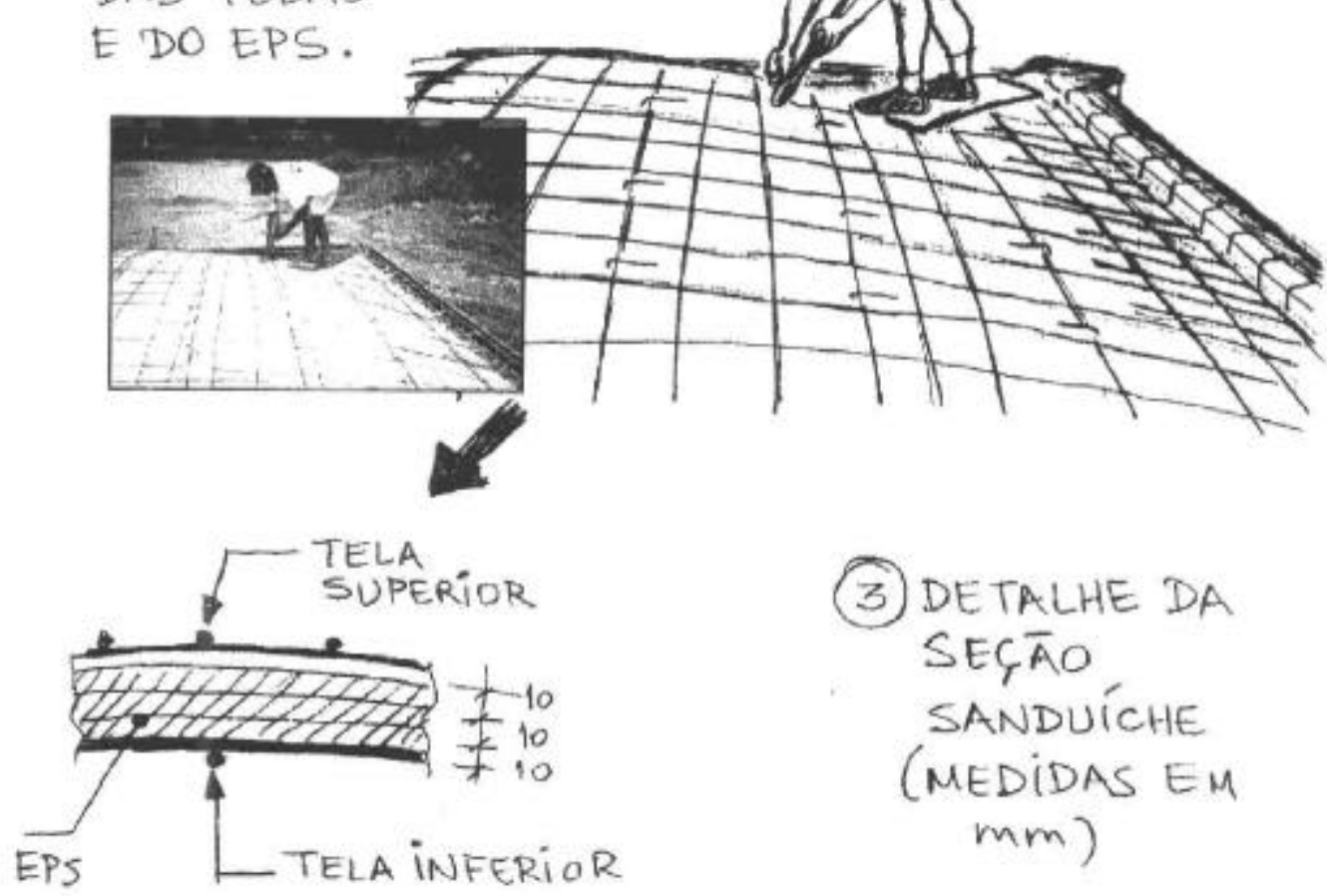

(3) DETALHE DA SEC, ĀO SANDUÍCHE (MEDIDAS EM mm)

FIGURA 2.18 - SEQÜÊNCIA EXECUTIVA DA COLOCAÇÃO DO EPS (TEXEIRA, 1999). 


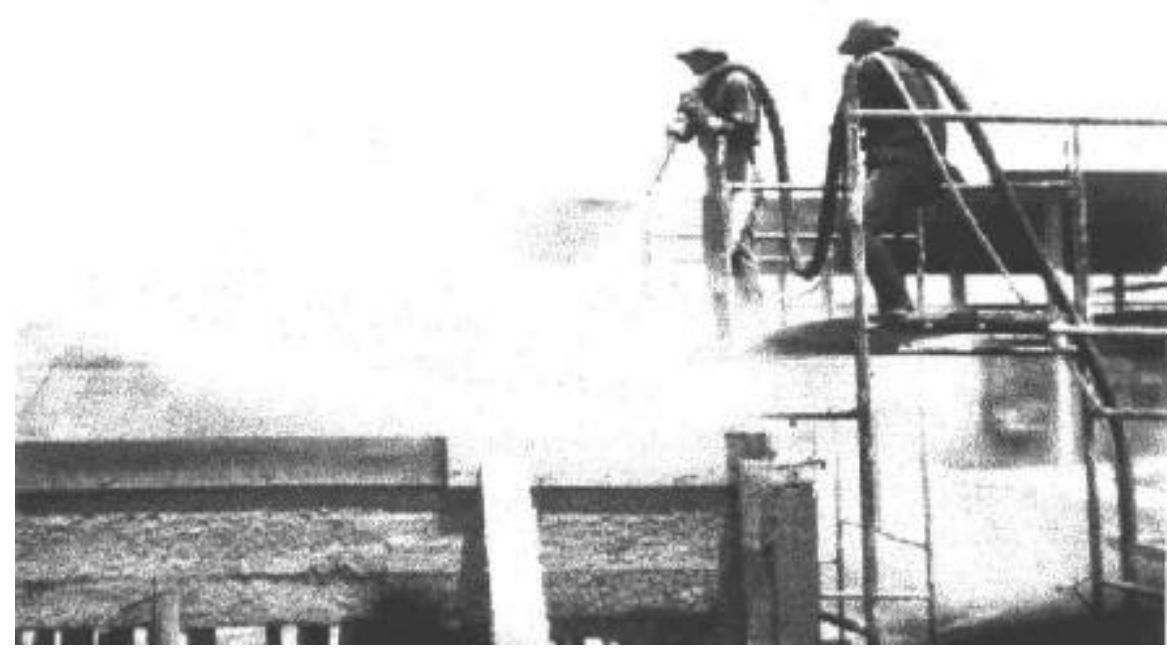

FIGURA 2.19 - CONCRETAGEM DA FACE SUPERIOR DO PROTÓTIPO (TEXEIRA, 1999).

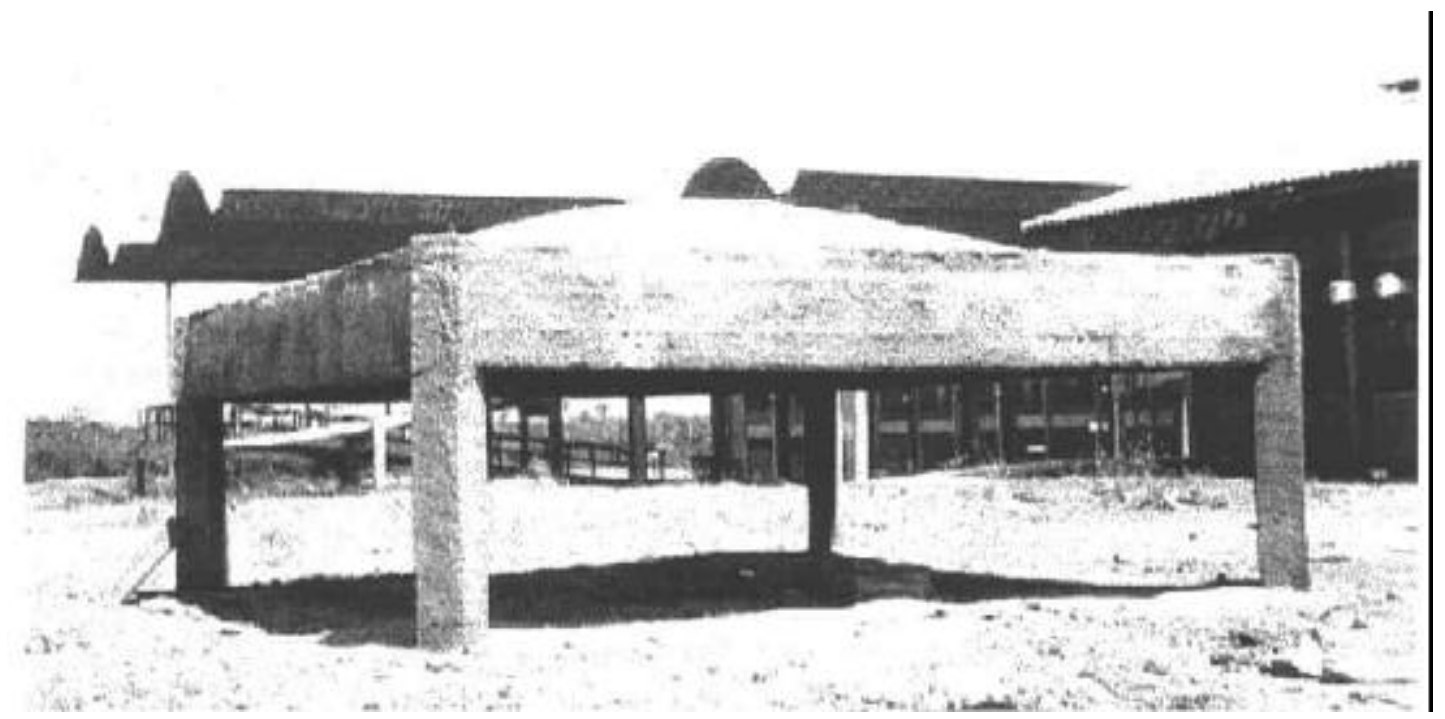

FIGURA 2.20 - VISTA DO PROTÓTIPO CONCLUÍDO (TEXEIRA, 1999).

Diante dos tipos de estrutura com painéis sanduíche com faces resistentes projetadas percebe-se que existe um potencial ainda não explorado para obras de infra-estrutura, como galerias, muros de arrimo, reservatórios de água, canais de drenagem, entre outros (fig.2.21). 


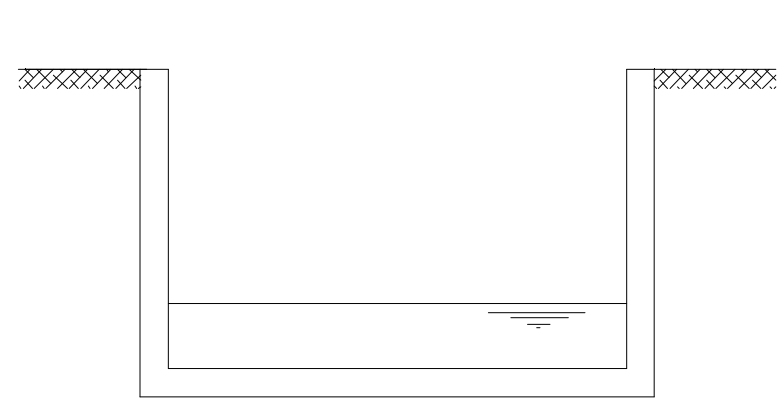

(a)

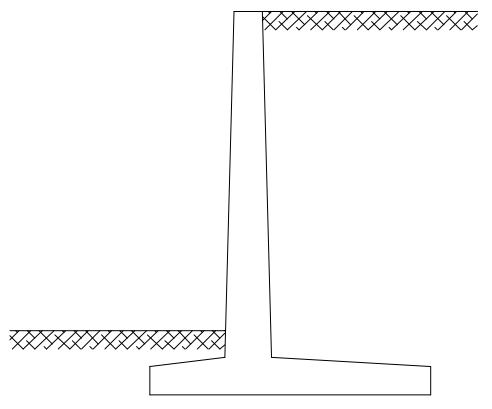

(b)

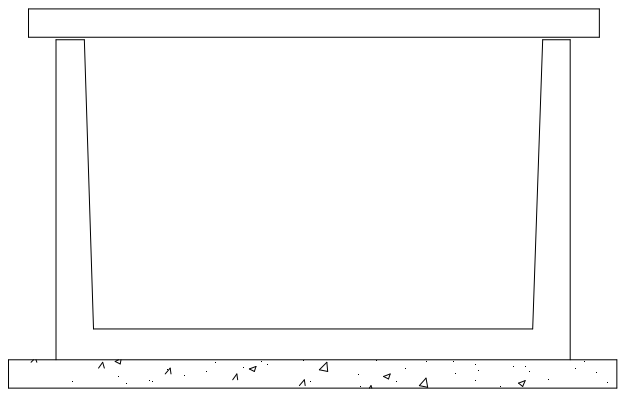

(c)

FIGURA 2.21- A) CANAl de SeÇão Retangular; B) Muro de ARrimo EM L; C) GALERIA DE SEÇÃO RETANGULAR

Nesses tipos de estrutura a fôrma encarece muito a construção, por se tratar de obras de grandes comprimentos. Além da vantagem de economia de fôrmas, o sistema tipo sanduíche possui a possibilidade de racionalização da construção, empregando técnicas de projeção da argamassa, execução da estrutura em lugares distantes dos grandes centros e de difícil acesso, utilização de mão-de-obra pouco especializada, utilização de rejeitos industriais ou resíduos agrícolas na confecção de núcleos e execução da obra através da autoconstrução.

Essas vantagens tornam atraente a utilização desse sistema em obras de infraestrutura, mas é preciso verificar a viabilidade estrutural dos elementos, visto que, mesmo para obras de edificações, existem poucos estudos científicos a respeito. Geralmente, as obras são executadas com base somente na experiência do construtor. 


\section{COMPORTAMENTO ESTRUTURAL}

\subsection{TIPOS DE SEÇÃO SANDUÍCHE}

Estruturas compostas são constituídas por duas ou mais camadas de materiais diferentes, as quais são admitidas perfeitamente aderidas, e a combinação delas faz com que o elemento, como um todo, ganhe em termos estruturais. A principal característica deste tipo de estrutura é a obtenção de elementos com boa rigidez e um baixo peso.

Estruturas sanduíche constituem um tipo particular de materiais compostos, constituídas por duas faces resistentes intercaladas por um material (núcleo), em geral de baixa densidade e menos resistente que as faces. Para o caso em estudo, as faces resistentes são placas de argamassa armada. O núcleo pode ser de EPS, poliestireno expandido, materiais reciclados de rejeitos industriais etc.

O núcleo é responsável tanto por manter as placas resistentes na posição correta quanto fazer a transferência de esforços de uma placa para outra. Alguns tipos de núcleo, como por exemplo o poliuretano e o poliestireno expandido, são pouco eficientes na transferência dos esforços. Nesses casos, a transferência das tensões de cisalhamento de uma placa para outra é garantida por nervuras ou por conectores, que atravessam o núcleo e são ancorados nas placas de argamassa.

Como a contribuição desses tipos de núcleo na transferência do cisalhamento é pequena, no projeto pode ser desprezada. Então, para estes casos, o grau de composição dos painéis é dado em função da eficiência dos conectores. Isto é medido por meio de ensaios, onde é verificada a eficiência desses conectores na transferência das tensões. Portanto, os conectores são utilizados para suprir a deficiência de núcleos muito fracos. 
Alguns núcleos ou mesmo conectores não são capazes de transferir $100 \%$ do cisalhamento entre as placas. Quando há $100 \%$ de transferência, a estrutura é considerada com composição total. Se a interação das placas resistentes for parcial, ou seja, a transferência do cisalhamento não for total, havendo uma significante deformação transversal, então será considerada composição parcial. O elemento é denominado não-composto quando não possui nenhuma interação das placas. A fig.3.1 ilustra os tipos de composição de uma seção sanduíche.

a)

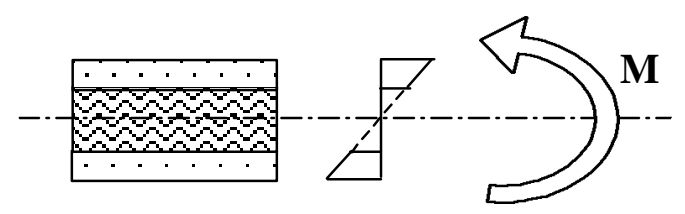

b)

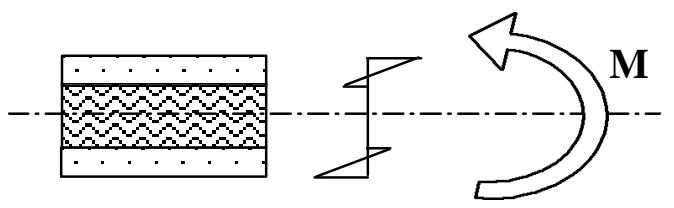

c)

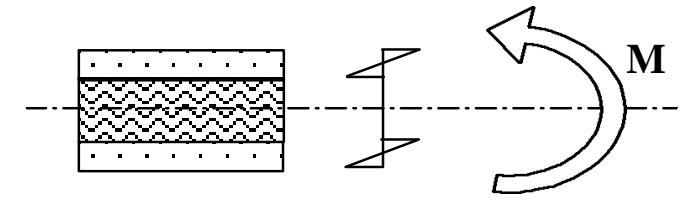

d)

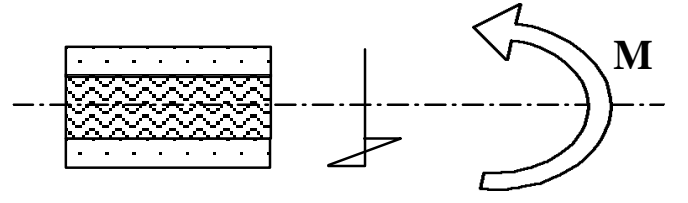

FIGURA 3.1 - TIPOS DE COMPOSIÇ̃̃o DE UMA SEÇÃO SANDUÍCHE.

a) COMPLETAMENTE COMPOSTA; b) PARCIALMENTE COMPOSTA; c) NÃOCOMPOSTA; d) NÃO-COMPOSTA COM UMA FACE RESISTENTE

No painel totalmente composto, a seção transversal funciona como se fosse um seção única, de inércia majorada pelo afastamento das faces devido à presença do núcleo. Não existe deslocamento relativo entre as duas placas, onde ambas possuem função estrutural e resistem em conjunto aos esforços a que estão submetidas.

A garantia da composição total entre as placas requer uso excessivo de conectores, o que muitas vezes se torna antieconômico. Na maioria dos casos, a quantidade e a disposição dos conectores estão mais relacionadas a aspectos construtivos do que à necessidade de garantir a composição integral. Do que se tem conhecimento em painéis tipo sanduíche é que, primeiro, se procura dispor de conectores dentro de um limite mínimo recomendado pela experiência, para então 
determinar qual o grau de composição obtido com essa disposição. Esse limite mínimo está intrinsecamente ligado ao fator econômico.

A determinação do grau de composição entre as placas exige um estudo experimental para cada tipo de conector considerado. Como os tipos e a disposição dos conectores podem ser de infinitas formas, de maneira geral torna-se difícil caracterizar a composição de uma estrutura sanduíche.

Muitas vezes, em se tratando de painéis para uso em edificações, se faz necessário admitir seções sanduíche sem interação das faces ou com interação parcial. Em alguns casos, quando o processo de produção é a pré-fabricação, a interação total só é considerada nas fases de moldagem, transporte e montagem dos painéis na obra. Para dimensioná-lo para as ações de uso, os painéis são considerados parcialmente compostos ou mesmo não-compostos.

$\mathrm{Na}$ seção não composta, o funcionamento entre as duas faces se dá de maneira independente. Os conectores não são capazes de transferir o cisalhamento entre as faces ou transmitem apenas uma parcela insignificante. Essas seções são utilizadas em painéis tipo $\Pi$ ou em lajes alveolares. Em regiões de inverno rigoroso, as indústrias reforçam o isolamento térmico dos painéis tradicionais com camada de material isolante, protegido por uma segunda placa de concreto, que pode ser um outro painel ou simplesmente um revestimento. Pode-se ter, então, segundo as figuras 3.1-c) e d), dois tipos de seção não composta: uma com duas placas resistentes e outra com apenas uma placa resistente.

\subsection{CÁLCULO DE ESTRUTURAS TIPO SANDUÍCHE}

Para um elemento com seção sanduíche totalmente composta, a análise estrutural é feita por meio da teoria elementar da flexão, onde a deformação transversal é desprezada. Quando se utilizam conectores flexíveis, há uma diminuição na rigidez do painel, o que permite deformações transversais significantes, que devem ser levadas em conta na análise estrutural.

Alguns autores apresentaram resolução, empregando o Método dos Elementos Finitos, como, por exemplo, HINTON \& OWEN (1984). Eles desenvolveram um programa para análise de cascas e placas de laminados compostos que utiliza elementos finitos isoparamétricos de oito a nove nós, com matriz de 
rigidez obtida através da integração numérica de Gauss, sendo que ao longo da espessura se aplica o Método do Estrato (Layered Model). Pode-se levar em consideração a deformação transversal. O procedimento interativo da solução do sistema não-linear é feito através de algoritmos do tipo Newton Ramphson, podendo levar em conta as não-linearidades física e geométrica.

Alguns programas computacionais com base no Método dos Elementos Finitos dispõem de elementos específicos para a análise de estruturas compostas, como, por exemplo, o ANSYS e o LUSAS.

ALLEN (1969), PLANTEMA (1966) e HARTSOCK (1976) propõem expressões analíticas para o cálculo dos deslocamentos e das tensões em estruturas tipo sanduíche sujeitas à flexão e à compressão. ALLEN (1969) apresenta um estudo bem detalhado sobre estruturas tipo sanduíche, abordando tanto o comportamento à flexão como o comportamento à compressão. Ainda traz uma vasta bibliografia, organizada por assunto. Esse livro é uma das obras de grande importância sobre o assunto, mencionada na maioria dos artigos publicados em congressos, revistas etc., sobre o tema em questão.

ALLEN (1969) considera o problema da transferência de cisalhamento entre as faces, levando em conta a contribuição do núcleo através de seu módulo de deformação transversal $(\mathrm{G})$. Todas as equações trazem embutido o valor de $\mathrm{G}$.

Sendo $d$ a distância entre os eixos das faces, e $t$ a espessura dessas faces, conforme indicado na fig.3.2, o autor citado classifica as estruturas tipo sanduíche em função das espessuras das faces, com base nas seguintes relações:

$\begin{array}{ll}\text { - faces muito finas: } & \frac{d}{t}>100 \\ \text { - faces finas: } & 100>\frac{d}{t}>5,77 \\ \text { - faces grossas } & \frac{d}{t}<5,77\end{array}$

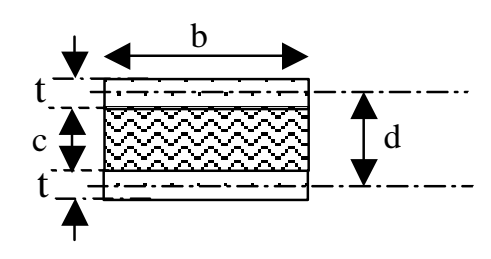

FIGURA 3.2 - DIMENSÕES DE UM ELEMENTO TIPO SANDUÍCHE 
Para os dois primeiros casos (faces muito finas e faces finas), não se considera a contribuição das faces na rigidez da seção inteira. Para faces grossas, a rigidez da seção inteira inclui a contribuição das faces.

Supondo-se um elemento tipo sanduíche com faces de argamassa de $3 \mathrm{~cm}$ de espessura e núcleo de $7 \mathrm{~cm}$ (dimensões bastante utilizadas na prática), esse elemento, segundo a classificação de Allen, seria enquadrado como de faces grossas $(\mathrm{d} / \mathrm{t}=$ $3,33)$. O método de solução desenvolvido para esse caso envolve a seguinte equação diferencial:

$$
\mathrm{Q}_{1}^{\prime \prime}-\mathrm{a}^{2} \mathrm{Q}_{1}=-\mathrm{a}^{2} \mathrm{Q}
$$

onde:

$\mathrm{Q}_{1}=$ força cortante, considerando um núcleo rígido $(\mathrm{G}=\infty)$;

$\mathrm{Q}=$ força cortante total aplicada na seção tipo sanduíche;

$\mathrm{a}^{2}=\frac{\mathrm{AG}}{\mathrm{EI}_{\mathrm{f}}\left(1-\mathrm{I}_{\mathrm{f}} / \mathrm{I}\right)}$

$\mathrm{A}=\mathrm{bd}^{2} / \mathrm{c}$

$\mathrm{G}=$ módulo de elasticidade transversal do núcleo;

b = largura da seção;

c = espessura do núcleo;

$\mathrm{E}=$ módulo de elasticidade longitudinal das faces;

$\mathrm{I}_{\mathrm{f}}=$ momento de inércia da face;

I = momento de inércia da seção sanduíche, desprezando a seção do núcleo.

Para cada situação de carregamento do elemento, a equação é resolvida, e são determinados os deslocamentos, as deformações, as tensões de compressão nas faces e as tensões de cisalhamento no núcleo.

Neste método de solução, além de um desenvolvimento matemático laborioso, existe o agravante de se necessitar do módulo de elasticidade transversal do núcleo.

Para o caso específico de estruturas tipo sanduíche em que as faces são moldadas no local da obra por meio de projeção da argamassa, fica difícil estimar qual o valor da rigidez transversal (AG), já que as faces podem estar conectadas por barras de aço, nervuras de argamassa etc. Para um determinado tipo de conector, é 
possível, através de ensaios, relacionar a taxa de transferência de cisalhamento a um valor de G, e aí utilizar as expressões de Allen.

Em seus estudos, BUSH \& WU (1998) utilizaram conectores tipo treliça e os relacionaram analiticamente a um valor de $\mathrm{G}$, em função da geometria da treliça. Seus resultados foram ainda aferidos por uma simulação numérica, utilizando-se o MEF, obtendo resultados satisfatórios.

SALMON et al (1996) fazem um estudo para o cálculo dos deslocamentos de elementos tipo sanduíche parcialmente compostos, levando em conta a flexibilidade dos conectores que interligam as faces. São feitas comparações, utilizando análise por meio do MEF, obtendo-se resultados muito próximos dos obtidos através das equações. Nesse cálculo é associada aos conectores uma rigidez $\mathrm{K}$, determinada a partir de expressões que dependem da forma e da disposição desses conectores.

SHEPPARD \& PHILLIPS (1989) sugerem um procedimento bastante interessante para levar em conta a composição parcial de uma seção tipo sanduíche com faces de concreto interligadas por conectores ou nervuras. Para a seção mostrada na fig.3.3, o momento de inércia é dado por:

$$
\mathrm{I}=\frac{\mathrm{b}}{12}\left(\mathrm{~h}^{3}-\mathrm{c}^{3}\right)
$$

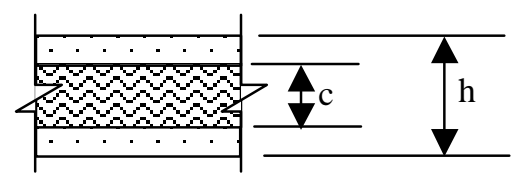

FIGURA 3.3 - SEÇÃO TIPO SANDUÍCHE

O valor da inércia deve ser corrigido em função da rigidez dos conectores ou das nervuras.

$$
\mathrm{I}_{\text {corrigido }}=\mathrm{CI} \text {, }
$$

onde I é o valor do momento de inércia da seção inteira e $\mathrm{C}$ o fator de correção.

Os mesmos autores indicam os valores de C, mostrados na tab.3.1, determinados a partir de ensaios com diferentes tipos de conexão entre as faces. 
TABELA 3.1 - Valores do coeficiente de correção.

\begin{tabular}{l|c}
\hline Tipo de ligação entre a faces & Valor de C \\
\hline $\begin{array}{l}\text { Faces conectadas por núcleo isolante rígido ou por conector de metal } \\
\text { sem resistência ao cisalhamento }\end{array}$ & 0,22 \\
\hline Painéis somente com nervura de concreto na borda & 0,39 \\
\hline Painéis com conectores tipo treliça metálica sem nervura de borda & 0,50 \\
\hline $\begin{array}{l}\text { Painéis com conectores tipo treliças metálicas ou cravo de aço com } \\
\text { nervuras de concreto nas bordas }\end{array}$ & 0,70 \\
\hline
\end{tabular}

Os valores indicados na tabela 3.1 são para solicitações na direção em que os conectores ou nervuras devem efetivamente trabalhar. Dependendo do tipo de ligação entre as faces, o coeficiente $\mathrm{C}$ pode ser utilizado também para a direção transversal do conector.

Com este procedimento abreviam-se bastante os cálculos, tomando-se uma inércia equivalente para representar a rigidez da ligação entre as faces. A seção tipo sanduíche passaria a ser tratada como uma seção equivalente, como mostra a fig.3.4.
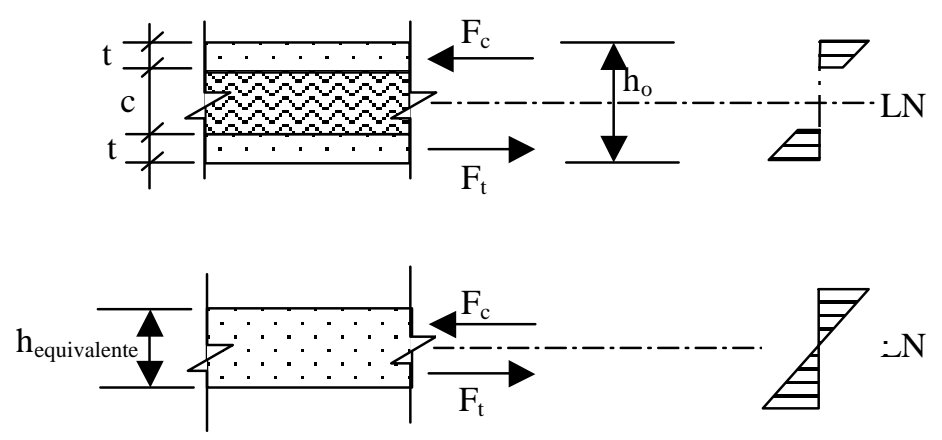

FIGURA 3.4 - SEÇÃO DE MESMA RIGIDEZ. DIAGRAMA DE TENSÕES

Como ilustração, uma seção tipo sanduíche com $\mathrm{t}=3 \mathrm{~cm}$ e $\mathrm{c}=8 \mathrm{~cm}$, adotando um valor de $C=0,40$, corresponderia a uma seção maciça com $h_{\text {equivalente }}=9,63 \mathrm{~cm}$. Mesmo com a perda de rigidez ter-se-ia uma seção equivalente, com espessura $62 \%$ maior do que aquela em que fossem consideradas apenas as seções das duas faces, com uma espessura de $6 \mathrm{~cm}$, que é a soma das espessuras de cada face.

Segundo SHEPPARD \& PHILLIPS(1989), elementos pré-moldados de concreto tipo sanduíche devem ser projetados para esforços provenientes de operações de manuseio (transporte, desmoldagem e montagem), ações de uso e variações volumétricas. Os esforços solicitantes críticos ocorrem quando os 
elementos são sujeitos ao içamento; logo, seu dimensionamento deve ser feito considerando-se a seção não fissurada.

Elementos tipo sanduíche com faces moldadas na obra devem ser dimensionados para as ações de uso, já que não existem as etapas de desmoldagem, transporte e montagem.

A estabilidade de estruturas tipo sanduíche sujeitas à flexo-compressão pode ser verificada conforme a NBR-6118 (1982), considerando-se a excentricidade total em relação ao plano médio da seção, que é a soma das excentricidades do carregamento com as ocorridas nas imperfeições de execução. A excentricidade decorrente dos efeitos de segunda ordem deve ser considerada quando a esbeltez $\lambda$ for maior que 40 .

\subsection{ENSAIOS REALIZADOS EM ESTRUTURAS TIPO SANDUÍCHE}

Vários foram os autores que investigaram o comportamento estrutural de elementos tipo sanduíche através de ensaios de laboratório, como, por exemplo: BUSH \& STINE (1994); HANAI \& TAKEYA (1994); BANSUNBUL et al (1991); LEE et al (1986); NANNI \& CHANG (1986); PFEIFER \& HANSON (1965).

\subsubsection{Ensaios realizados por BANSUNBUL et al (1991)}

BANSUNBUL et al (1991) realizaram ensaios de flexão com painéis nervurados, que efetivamente apresentavam comportamento composto ou muito próximo disso. Na avaliação teórica, a seção transversal dos painéis era considerada como uma seção usual de concreto armado. Os parâmetros considerados na investigação experimental eram o número de camadas da tela soldada e a quantidade de armadura de reforço (ambos utilizados como armadura do painel), o número de nervuras e sua armadura. As propostas dessa investigação eram: estudar o comportamento à flexão de painéis sanduíche com faces de ferrocimento e contribuir para o seu projeto estrutural. Para isto foram ensaiados 12 painéis sanduíche, comparando-se os resultados obtidos experimentalmente com os resultados teóricos. Foram observados ainda o desenvolvimento das fissuras e o valor da carga última para todos os painéis.

Os modelos avaliados por BANSUNBUL et al (1991) são mostrados na fig.3.5. A seção transversal consistia em placas de ferrocimento com $2 \mathrm{~cm}$ de 
espessura, variando o número de telas soldadas para cada modelo, com ou sem armadura de reforço. As nervuras eram armadas com fios de $4 \mathrm{~mm}$ de diâmetro (shear connectors), variando o seu número entre 3 e 5, como mostra a fig.3.5. Estes fios eram espaçados de $25 \mathrm{~cm}$ longitudinalmente. O núcleo do painel era constituído por uma espuma rígida de poliestireno de $11 \mathrm{~cm}$ de espessura. A seção transversal do painel tinha $120 \mathrm{~cm}$ de largura por $15 \mathrm{~cm}$ de altura, com comprimento de $240 \mathrm{~cm}$.

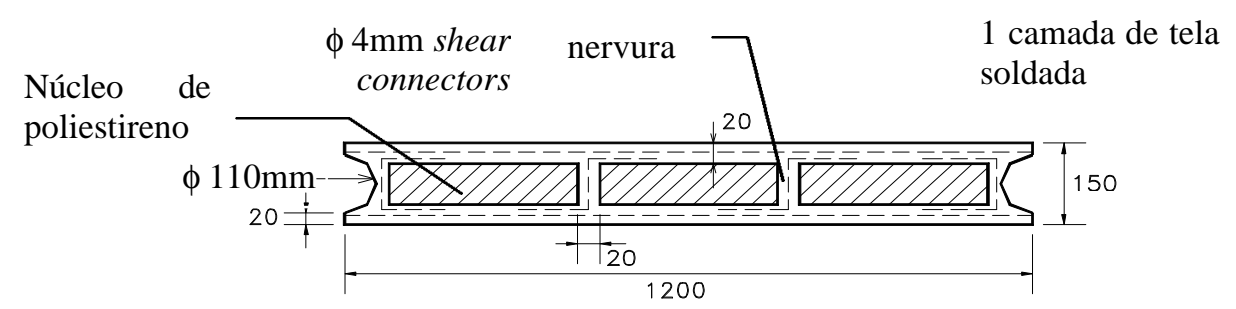

(a)

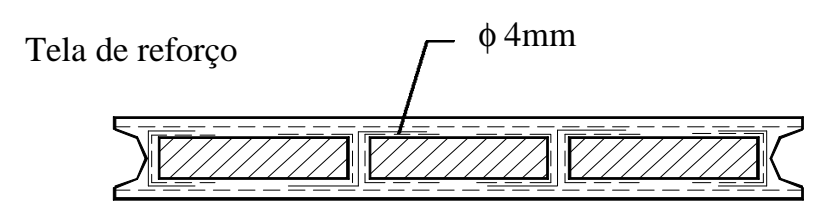

(b)

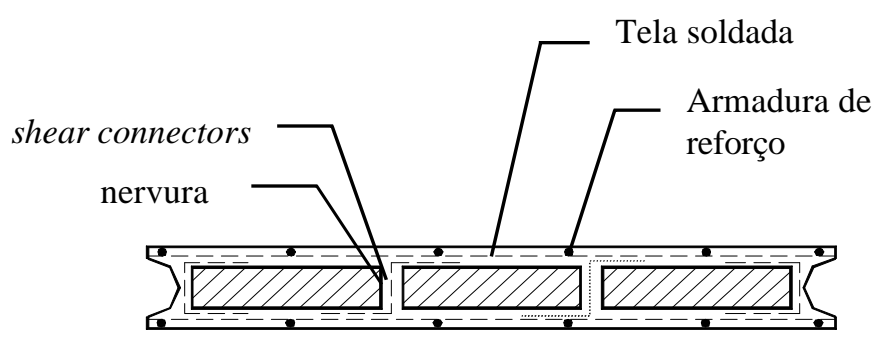

(c)

FIGURA 3.5 - SEÇÃO TRANSVERSAL TÍPICA DOS PAINÉIS ENSAIADOS POR BANSUNBUL ET AL (1991). A) SHEAR CONNECTORS COM FIOS; B) SHEAR CONNECTORS COM FIOS DE TELA SOLDADA; C) FACES COM ARMADURAS DE REFORÇO (DIMENSÃO EM MM)

Em função dos resultados obtidos dos ensaios, as principais conclusões feitas por BANSUNBUL et al (1991) foram:

- O número de nervuras e a presença de tela soldada na armadura desempenham importante função no desenvolvimento da capacidade do momento resistente; 
- Aumento do número de nervuras, além do número necessário para desenvolver a capacidade última do momento resistente, não melhora o comportamento do painel à flexão;

- A teoria clássica do concreto estima com razoável precisão o momento resistente do painel.

NANNI \& CHANG (1986) estudaram painéis submetidos à flexão simples e à compressão centrada. Os modelos obedeciam às características dos painéis destinados à fabricação de módulos residenciais, propostos por CHANG \& NANNI (1985). Os resultados mostram-se satisfatórios com os painéis, apresentando comportamento próximo ao composto.

\subsubsection{Ensaios realizados por LEE et al (1986)}

LEE et al. (1986) realizaram investigações experimentais em painéis sanduíche com faces de ferrocimento e núcleo de poliestireno expandido. Os parâmetros de estudo eram a quantidade de armadura e o método de transferência de cisalhamento entre as faces.

No total foram considerados seis modelos diferentes, como mostra a fig.3.6. Todos os painéis tinham núcleo de poliestireno com $2,5 \mathrm{~cm}$ de espessura.

Na série D (figuras 3.6a e b)), os conectores eram barras de aço inclinadas em $45^{0}$ em relação ao plano da face, atravessavam o núcleo e eram soldadas nas armaduras das placas de ferrocimento.

$\mathrm{Na}$ série $\mathrm{N}$ (figuras 3.6 $\mathrm{c}$ a $\mathrm{f}$ ), a transferência de cisalhamento era garantida por treliças metálicas espaçadas de $60 \mathrm{~cm}$. Essas treliças ficavam dentro de nervuras de argamassa de $25 \mathrm{~mm}$ de espessura, que uniam as duas faces. A principal diferença entre os vários modelos da mesma série era a quantidade de armadura das faces.

LEE et al.(1986) dividiram seus estudos em três partes:

- Seleção da proporção da mistura da argamassa;

- Estudo das faces de ferrocimento isoladamente;

- Estudo do painel sanduíche.

$\mathrm{Na}$ primeira parte do estudo, quatro diferentes traços de argamassa foram testados, verificando-se a consistência necessária à aplicação da argamassa. Estudos sobre a retração também foram realizados. Foi selecionada para execução dos modelos uma argamassa com traço de 1:3 e relação água-cimento de 0,65 , para a 
qual se obteve uma resistência à compressão de 26,2 MPa. Com essa mistura eram possíveis tanto a projeção manual como a mecânica.

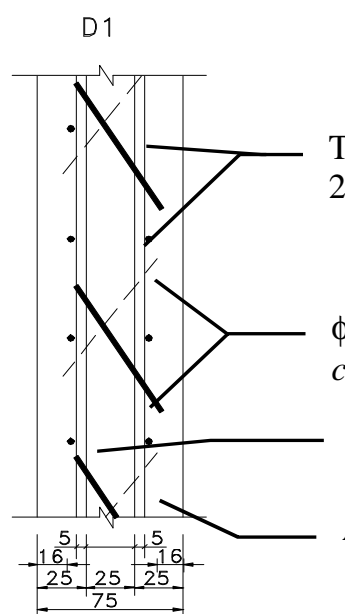

(a)

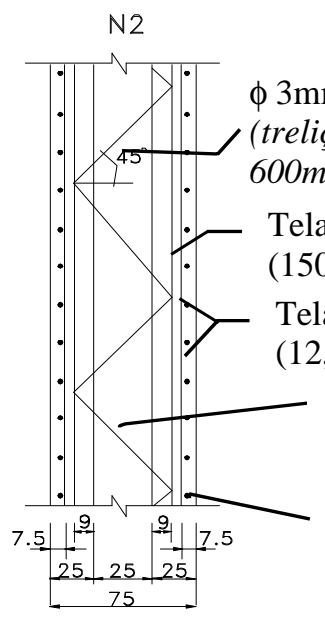

(d)

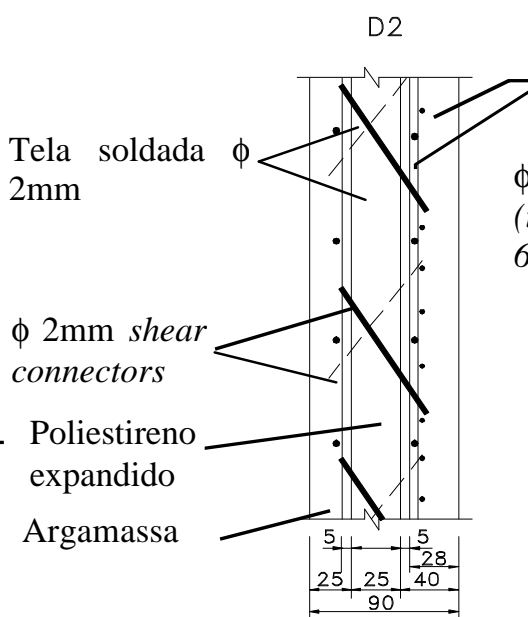

(b)

N3

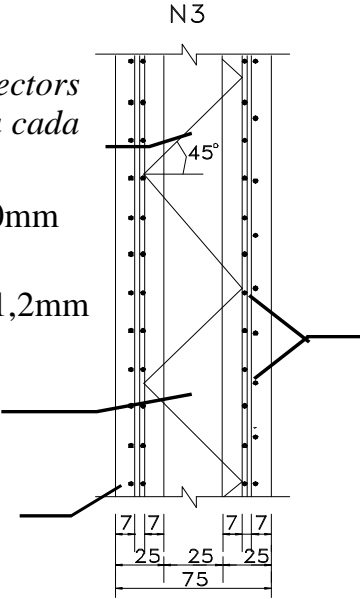

(e)
N1

Tela soldada $\phi 1,2 \mathrm{~mm}$ (25 x 25mm)

$\phi 3 \mathrm{~mm}$ shear connectors (treliça metálica) a cada $600 \mathrm{~mm}$

Tela soldada $\phi 3,0 \mathrm{~mm}$ (150 x 150mm)

Tela soldada $\phi 1,2 \mathrm{~mm}$ $(12,5 \times 12,5 \mathrm{~mm})$

Poliestireno expandido Argamassa

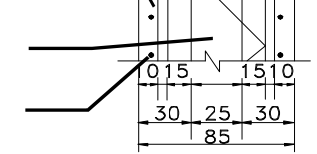

(c)

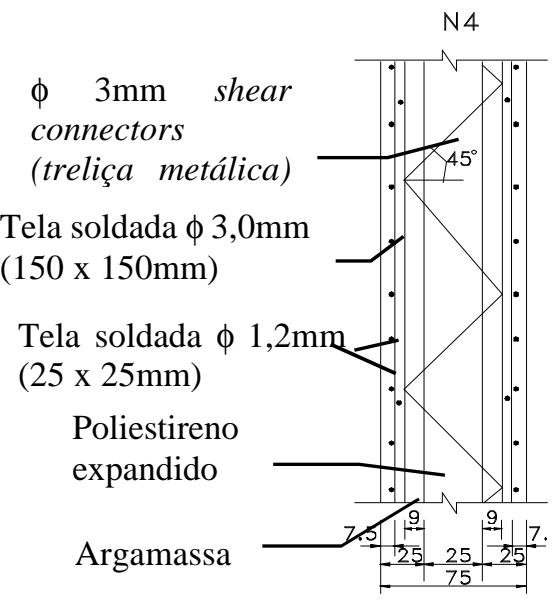

(f)

FIGURA 3.6 - DETALHES DOS PAINÉIS ENSAIADOS POR LEE ET AL (1986)

Na segunda fase do estudo, foram realizados ensaios de flexão e de tração nos elementos das faces e também testes de retração.

A última parte do trabalho foi o estudo do comportamento dos painéis sanduíche, baseando-se nos ensaios preliminares dos elementos de face. Os painéis também foram submetidos a testes de retração.

Todos os modelos das séries tinham 2,4m de comprimento e 1,2m de largura. Nervuras transversais de $2,5 \mathrm{~cm}$ de espessura foram executadas ao longo dos pontos de carregamento, para melhor transferência de carga. Alguns modelos tinham 
nervuras longitudinais espaçadas de $60 \mathrm{~cm}$, que continham as treliças. Os painéis simplesmente apoiados nas extremidades do vão de 2,4m foram ensaiados aplicandose um carregamento nos terços do vão. O gráfico força versus deslocamento dos painéis ensaiados é mostrado na fig.3.7. Como se pode observar, a carga de primeira fissura é praticamente igual para todos os painéis ensaiados.

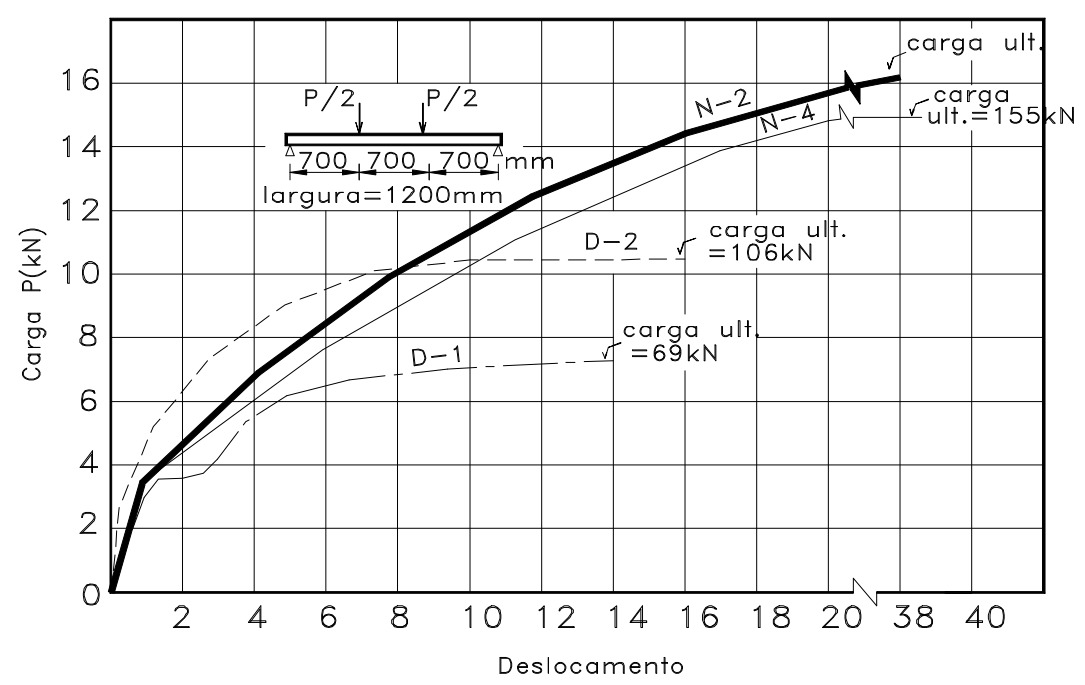

FIGURA 3.7 - GRÁFICO FORÇA X DESLOC. DOS PAINÉIS ENSAIADOS POR LEE ET AL (1986)

LEE et al (1986), baseados em seus estudos, puderam designar, para cada tipo de painel ensaiado, a sua melhor utilização, seja para painéis exteriores, mais sujeitos a intempéries, ou interiores, não sujeitos a ações externas. Ainda LEE et al (1986) ressaltam que a resistência da composição depende da taxa volumétrica de armadura e que uma melhor distribuição dessa armadura ao longo da espessura das placas resistentes proporciona melhor controle das fissuras. É recomendado que se coloquem, no painel, armaduras de reforço nos cantos de portas e janelas.

\subsubsection{Ensaios realizados por HANAI \& TAKEYA (1994)}

HANAI \& TAKEYA (1994), no Laboratório de Estruturas da Escola de Engenharia de São Carlos, realizaram ensaios com painéis sanduíche da CABRINI MONOLITE Ind. e Com. Ltda., que tinham como objetivo analisar o comportamento de painéis quando submetidos a solicitações de flexão e de cisalhamento. Buscava-se quantificar a contribuição dos fios transversais de aço que serviam de conectores, e 
ainda a contribuição da aderência entre as placas de argamassa armada e o núcleo de poliestireno expandido.

Foram executadas duas séries de modelos, com três exemplares cada, cuja única diferença de projeto foi a colocação de núcleo de poliestireno contínuo ou seccionado. Os pré-painéis eram elementos constituídos de núcleo de poliestireno expandido, associado a telas soldadas, conforme mostra a fig.3.8.

Para execução dos modelos, esses pré-painéis foram cortados com as dimensões de $300 \mathrm{~cm}$ x $56 \mathrm{~cm}$ (metade da largura padronizada). As placas eram moldadas com argamassa armada, constituída por fios longitudinais de $2,8 \mathrm{~mm}$ de diâmetro, com espaçamento variável entre $5 \mathrm{~cm}$ e $10 \mathrm{~cm}$, e fios transversais de $2,3 \mathrm{~mm}$ de diâmetro, com espaçamento de $13 \mathrm{~cm}$. Os fios que serviam de conector eram alinhados em três filas longitudinais, com barras espaçadas a cada $13 \mathrm{~cm}$.

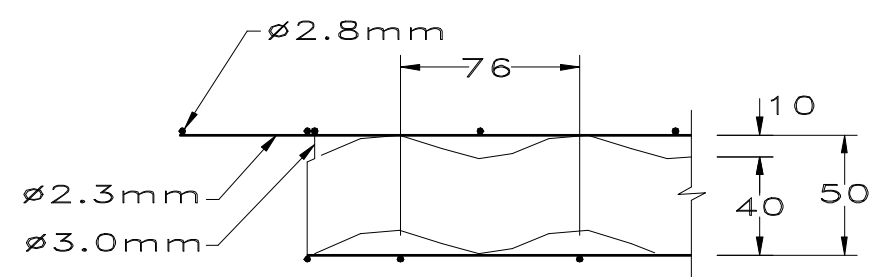

FIGURA 3.8 - CARACTERÍSTICAS GERAIS DO PRÉ-PAINEL (HANAI \& TAKEYA, 1994)

As placas foram moldadas com argamassa que continha $0,1 \%$ (em volume) de fibras de polipropileno. A argamassa apresentou resistência à compressão, na idade da realização dos ensaios, entre 29,7MPa e 39,2MPa, dependendo da placa e da série realizada. O painel simplesmente apoiado foi submetido a duas forças concentradas, conforme esquema mostrado na fig.3.9.

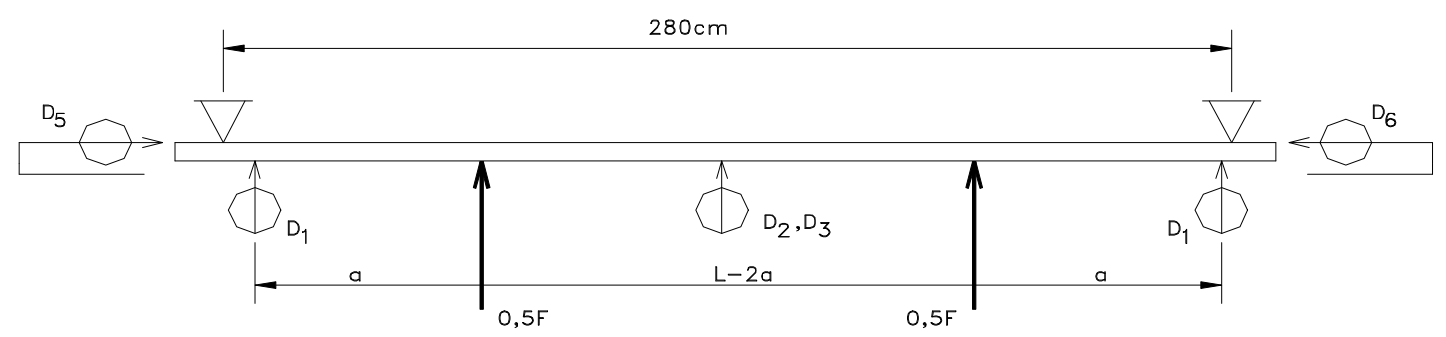

FIGURA 3.9 - ESQUEMA DE CARREGAMENTO E INSTRUMENTAÇÃO DOS MODELOS

(HANAI \& TAKEIA, 1994) 
A distância "a" do ponto de aplicação de cada força ao apoio adjacente variou em cada exemplar ensaiado, para se obter resultados para diferentes valores de $\mathrm{M} / \mathrm{V}$ (relação momento fletor/força cortante), uma vez que interessava particularmente observar o desempenho dos conectores ao cisalhamento. Os valores da força cortante, do momento fletor e dos deslocamentos foram medidos em cada etapa de carregamento do ensaio de flexão dos painéis.

Os resultados experimentais obtidos nos ensaios de flexão foram comparados com resultados teóricos correspondentes a duas situações de funcionamento do painel:

a) painel de comportamento composto;

b) painel de comportamento não-composto.

Dos resultados dos ensaios, HANAI \& TAKEYA (1994) puderam constatar que o núcleo de poliestireno promove uma boa contribuição na composição do painel e que os conectores de ligação da tela soldada não oferecem contribuição significativa ao cisalhamento.

Da comparação teórica versus experimental, HANAI \& TAKEYA (1994) puderam concluir que o grau de composição com relação ao momento de fissuração (cerca de 35\%) provavelmente reflete somente a aderência do núcleo às faces de argamassa, uma vez que os conectores não ofereciam resistência significativa ao cisalhamento. Ainda ressalta-se que o cálculo teórico do momento resistente dos painéis, considerando-se comportamento composto, oferece uma estimativa segura do momento resistente de painéis com núcleo contínuo, no que se refere à capacidade de carga, desconsiderando-se a questão da deformação excessiva.

\subsubsection{Ensaios realizados por BUSH \& STINE (1994)}

BUSH \& STINE (1994) realizaram ensaios em modelos de painéis de concreto tipo sanduíche, com o objetivo de avaliar a composição entre as placas com conectores rígidos de treliças metálicas contínuas. Ainda procuraram avaliar a eficiência da treliça ao cisalhamento e a aderência da placa ao isolante. Foram realizadas duas séries com painéis tipo sanduíche. Uma primeira série avaliou painéis produzidos segundo os critérios adotados na fábrica e utilizados em painéis disponíveis comercialmente. A segunda série estudou painéis que incorporavam 
modificações para melhor avaliar a transferência do cisalhamento entre as placas de concreto.

Os modelos ensaiados por BUSH \& STINE (1986) tinham $244 \mathrm{~cm}$ x $488 \mathrm{~cm}$, com espessura das placas de concreto de $7,62 \mathrm{~cm}$ e espessura do núcleo de poliestireno expandido de 5,08cm (fig.3.11). As dimensões da treliça metálica utilizada como conector são mostradas na fig.3.11. Essas treliças eram disponíveis comercialmente.

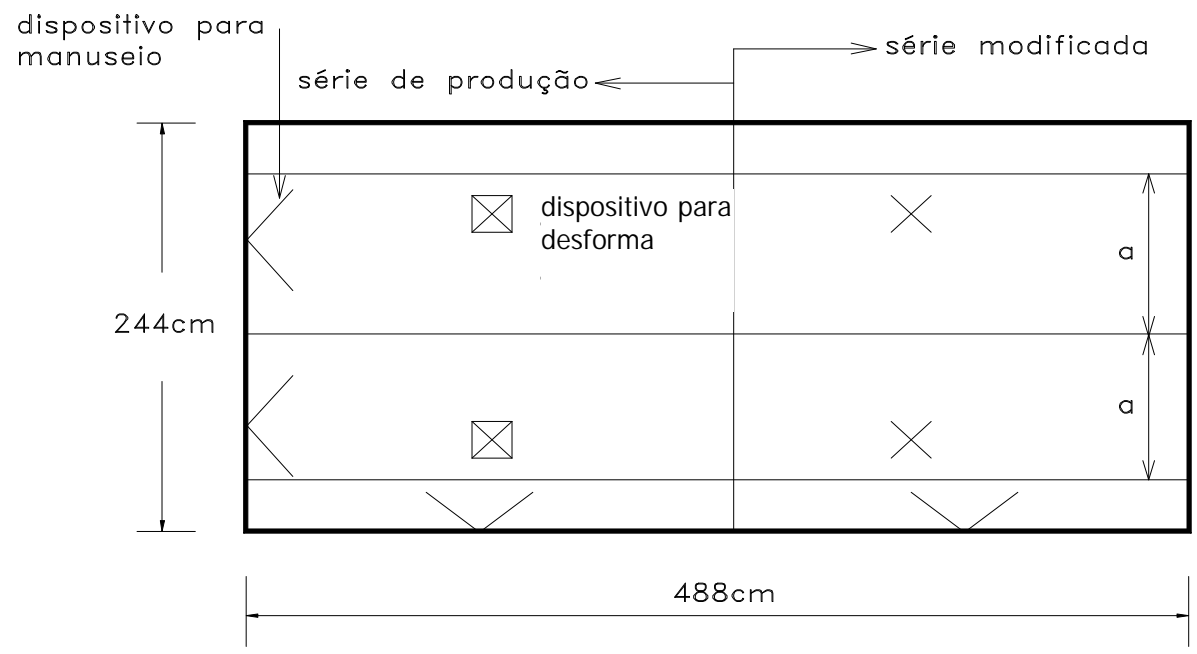

FIGURA 3.10 - GEOMETRIA DOS PAINÉIS ENSAIADOS POR BUSH \& STINE (1986)
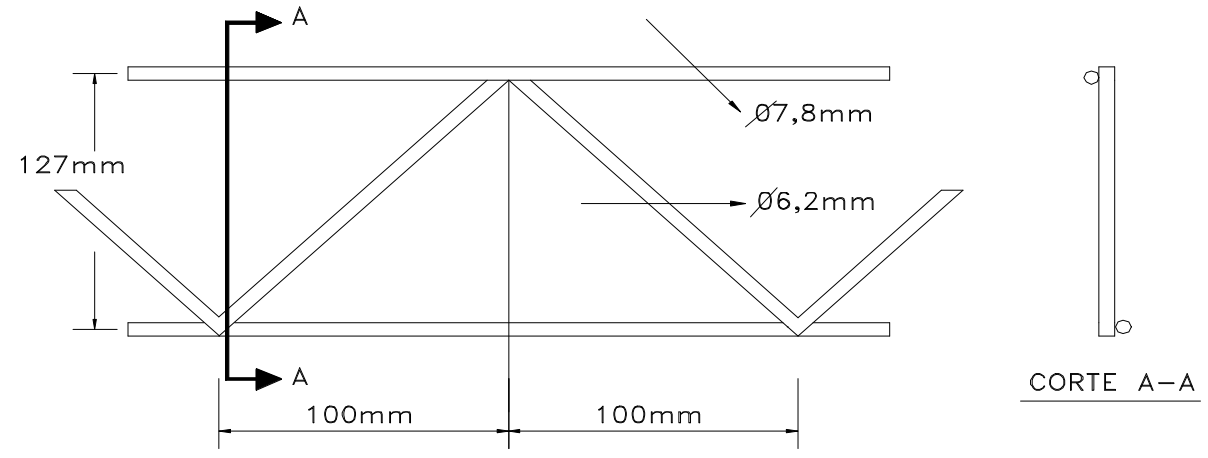

FIGURA 3.11 - GEOMETRIA DA TRELIÇA METÁLICA UTILIZADA NOS ENSAIOS DE BUSH \& STINE (1986) 
Para cada série foi verificada a eficiência dos conectores através de ensaios tipo pushout (fig.3.12).

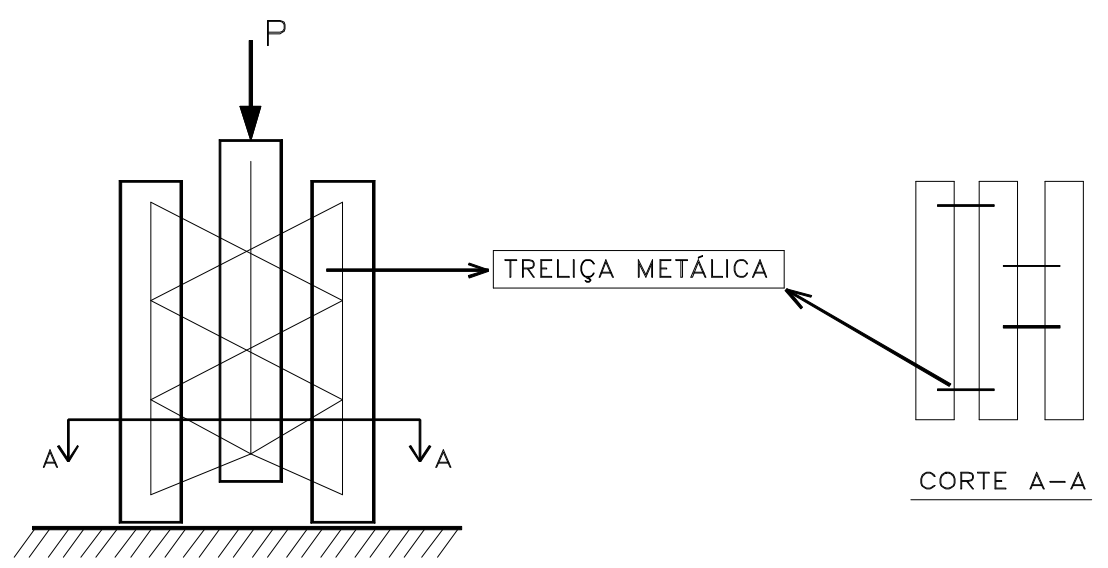

FIGURA 3.12 - ENSAIO TIPO PUSHOUT

O concreto utilizado na moldagem dos modelos apresentava resistência à compressão, na idade da realização dos ensaios, em torno de 40MPa.

Os painéis simplesmente apoiados foram submetidos a uma carga uniformemente distribuída por meio de um colchão de ar. Alguns painéis foram ensaiados por carregamentos cíclicos; estes foram submetidos a uma carga concentrada no meio do vão. Simulou-se ainda o efeito da variação da temperatura, através da aplicação de um esforço equivalente no painel.

Nos gráficos da fig.3.13 mostram-se as cargas aplicadas versus os deslocamentos obtidos nos ensaios de flexão dos painéis, indicando-se também as retas correspondentes à previsão teórica de flechas no estádio I, considerando-se comportamento composto e não-composto.

BUSH \& STINE (1994) verificaram que os modelos executados de acordo com os critérios adotados na fábrica possuíam vários pontos de infiltração de concreto (principalmente nos locais dos pontos de levantamento e de desforma e em volta dos conectores), o que se atribuiu a essas "nervuras extras", formadas pela infiltração, a boa transferência de cisalhamento entre as placas de concreto.

Ainda BUSH \& STINE (1994) verificaram nos ensaios cíclicos que a perda de aderência do núcleo às placas de concreto é muito pequena e pode ser considerada por toda a sua vida útil. Ressaltam ainda que a redundância na transferência do 
cisalhamento (treliça e aderência placas-isolante) permite uma redistribuição dos esforços e manutenção da resistência, mesmo quando as barras da treliça (conector) atingem a ruptura por escoamento do banzo inferior ou por flambagem do banzo comprimido.
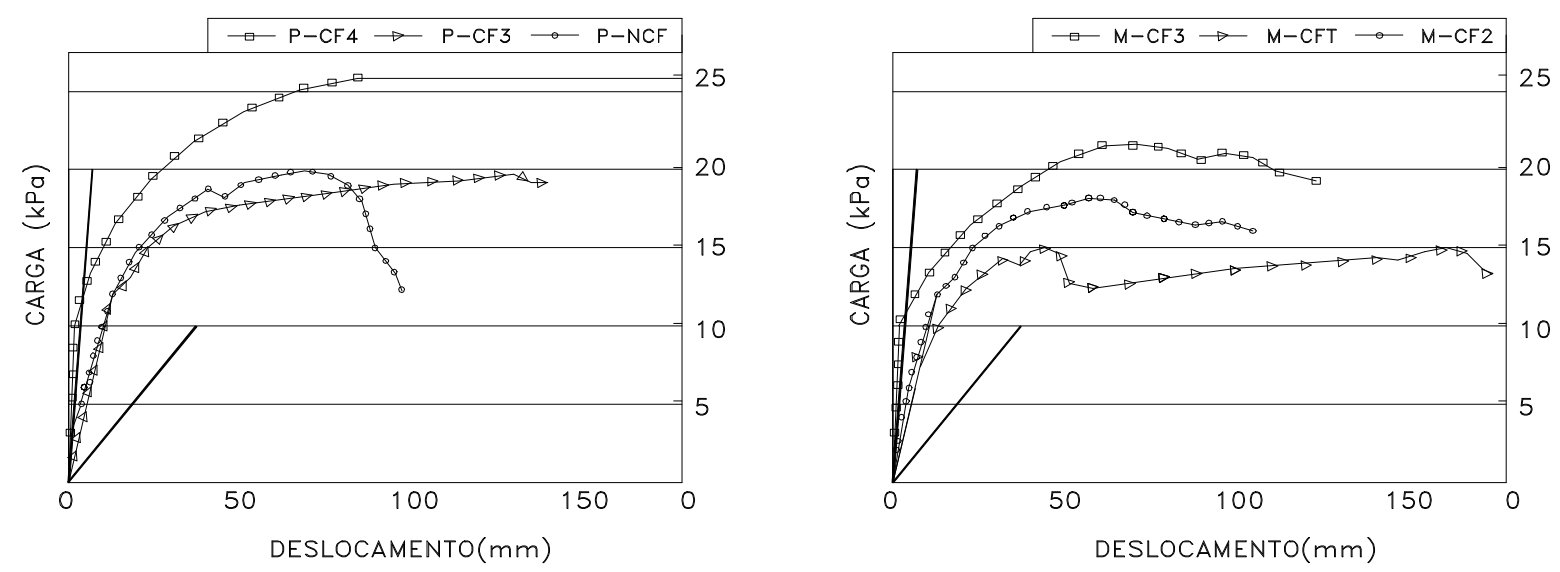

FIGURA 3.13 - GRÁFICO CARGA X DESLOCAMENTO DOS ENSAIOS À FLEXÃO REALIZADOS POR STINE \& BUSH (1994)

\subsubsection{Ensaios realizados por por PFEIFER \& HANSON (1965)}

Um estudo detalhado sobre o comportamento à flexão de painéis tipo sanduíche com disposição variada de conectores foi realizada por PFEIFER \& HANSON (1965), que analisaram as características gerais do painel, tais como: tipo de isolante, espessura da placa e tipo de conectores.

PFEIFER \& HANSON (1965) ensaiaram cerca de 50 modelos, cujas dimensões eram de $91,5 \mathrm{~cm}$ x $152,4 \mathrm{~cm}$. A espessura total dos painéis variava de $5,72 \mathrm{~cm}$ a $15,24 \mathrm{~cm}$. Mais detalhes dos modelos ensaiados e dos tipos de isolantes estão na tabela 3.2 .

O concreto utilizado na moldagem apresentava resistência à compressão $34 \mathrm{MPa}$ e 46Mpa, aos 28 dias entre.

Os painéis simplesmente apoiados foram submetidos a carregamento uniformemente distribuído através de um colchão de ar. Foram medidos os deslocamentos e a carga de primeira fissura. Embora os modelos tenham sido 
ensaiados até a ruptura, a análise dos resultados foi restrita a esforços inferiores ao correspondente momento de fissuração da peça.

TABELA 3.2 - Detalhes dos modelos de PEFEIFER \& HANSON (1965)

\begin{tabular}{|c|c|c|c|c|c|}
\hline Painel & $\begin{array}{c}\text { Espessura } \\
\text { (mm) }\end{array}$ & $\begin{array}{l}\text { tipo de } \\
\text { isolante }\end{array}$ & $\begin{array}{c}\text { espessura } \\
\text { do isolante } \\
(\mathrm{mm})\end{array}$ & tipo de conector & $\begin{array}{c}A_{s} \text { por placa } \\
\left(\mathrm{cm}^{2}\right)\end{array}$ \\
\hline A & 57,2 & poliuretano & 25,4 & treliça metálica & $1,53(1,05 \%)$ \\
\hline $\mathrm{B}$ & 63,5 & poliuretano & 25,4 & chapa de metal & $0,58(0,54 \%)$ \\
\hline $\mathrm{C}$ & 63,5 & poliuretano & 25,4 & 135 blocos $\phi 25,4 \mathrm{~mm}$ & $0,58(0,54 \%)$ \\
\hline $\mathrm{D}$ & 101,6 & poliuretano & 50,8 & tela soldada & $0,58(0,25 \%)$ \\
\hline $\mathrm{E}$ & 152,4 & poliuretano & 50,8 & nenhum & $0,58(0,12 \%)$ \\
\hline $\mathrm{F}$ & 127,0 & poliuretano & 50,8 & tela soldada & $0,58(0,17 \%)$ \\
\hline $\mathrm{G}$ & 127,0 & poliuretano & 50,8 & chapa de metal & $0,58(0,17 \%)$ \\
\hline $\mathrm{H}$ & 127,0 & poliuretano & 50,8 & nervuras borda $(50,8 \mathrm{~mm})$ & $0,58(0,17 \%)$ \\
\hline $\mathrm{J}$ & 127,0 & poliuretano & 50,8 & 22 blocos $\phi 38,1 \mathrm{~mm}$ & $0,58(0,17 \%)$ \\
\hline $\mathrm{K}$ & 127,0 & poliuretano & 50,8 & nervuras extr. $(38,1 \mathrm{~mm})$ & $0,58(0,17 \%)$ \\
\hline $\mathrm{L}$ & 127,0 & poliuretano & 50,8 & nervuras de borda + chapa & $0,58(0,17 \%)$ \\
\hline M & 152,4 & poliuretano & 50,8 & tela soldada & $0,58(0,12 \%)$ \\
\hline $\mathrm{N}$ & 88,9 & poliestireno & 38,1 & treliça metálica & $1,53(0,66 \%)$ \\
\hline $\mathrm{P}$ & 127,0 & poliestireno & 50,8 & nenhum & $0,58(0,17 \%)$ \\
\hline $\mathrm{R}$ & 127,0 & poliestireno & 50,8 & nenhum & $0,79(1,05 \%)$ \\
\hline $\mathrm{S}$ & 127,0 & poliestireno & 50,8 & nenhum & $0,58(0,17 \%)$ \\
\hline $\mathrm{T}$ & 127,0 & poliestireno & 50,8 & tela soldada & $0,58(0,17 \%)$ \\
\hline $\mathrm{U}$ & 127,0 & poliestireno & 50,8 & treliça metálica & $1,53(0,44 \%)$ \\
\hline $\mathrm{V}$ & 127,0 & poliestireno & 50,8 & treliça metálica & $1,53(0,44 \%)$ \\
\hline $\mathrm{W}$ & 127,0 & poliestireno & 50,8 & chapa de metal & $0,79(0,23 \%)$ \\
\hline$X$ & 127,0 & poliestireno & 50,8 & 135 blocos $\phi 25,4 \mathrm{~mm}$ & $0,58(0,17 \%)$ \\
\hline Y & 127,0 & poliestireno & 50,8 & nervuras borda $(38,1 \mathrm{~mm})$ & $0,58(0,17 \%)$ \\
\hline $\mathrm{Z}$ & 152,4 & poliestireno & 50,8 & treliça metálica & $1,53(0,44 \%)$ \\
\hline $\mathrm{AA}$ & 127,0 & fibra de vidro & 50,8 & tela soldada & $0,58(0,17 \%)$ \\
\hline $\mathrm{BB}$ & 127,0 & fibra de vidro & 50,8 & treliça metálica & $1,53(0,44 \%)$ \\
\hline $\mathrm{CC}$ & 127,0 & fibra de vidro & 50,8 & treliça metálica & $1,53(0,44 \%)$ \\
\hline DD & 127,0 & foamed glass & 50,8 & tela soldada & $0,58(0,17 \%)$ \\
\hline $\mathrm{EE}$ & 127,0 & foamed glass & 50,8 & treliça metálica & $1,53(0,44 \%)$ \\
\hline $\mathrm{FF}$ & 76,2 & $\begin{array}{l}\text { concreto } \\
\text { celular }\end{array}$ & 38,1 & nenhum & $0,58(0,33 \%)$ \\
\hline GG & 88,9 & $\begin{array}{l}\text { concreto } \\
\text { celular }\end{array}$ & 38,1 & nenhum & $0,58(0,25 \%)$ \\
\hline $\mathrm{HH}$ & 127,0 & $\begin{array}{l}\text { concreto } \\
\text { celular }\end{array}$ & 50,8 & nenhum & $0,58(0,17 \%)$ \\
\hline
\end{tabular}

PFEIFER \& HANSON (1965) observaram que a resistência superior e o comportamento mais próximo do composto, em painéis com núcleo de concreto celular e foamed glass, parece decorrer do elevado módulo de elasticidade desses materiais (cerca de $1200 \mathrm{MPa}$ ) em relação ao das espumas (menor que $7 \mathrm{MPa}$ ). A influência do tipo do isolante é mostrada na fig.3.14. 


\section{Tipo do material do núcleo:}

E, F, G: poliuretano

S, T, V: poliestireno

HH: concreto celular

E, DD: "foamed glass"

AA, BB: fibra de vidro

Painel sem conectores

(ligação por aderência)

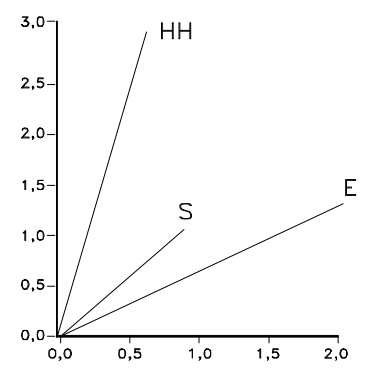

Painel sem conectores

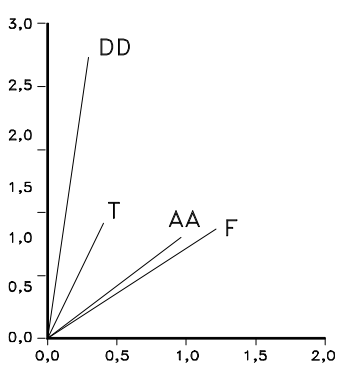

Treliça metálica ou placa de metal expandido

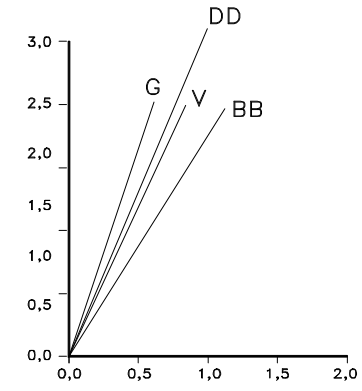

FIGURA 3.14 - GRÁFICO MOMENTO DE FISSURAÇÃO X DESLOCAMENTO SEGUNDO O TIPO DE ISOLANTE (PFEIFER \& HANSON, 1965)

Observando o gráfico da fig.3.15, obtido dos resultados dos ensaios de PFEIFER \& HANSON (1965), pode-se afirmar que o tipo de conector é a variável mais importante no comportamento do painel tipo sanduíche.

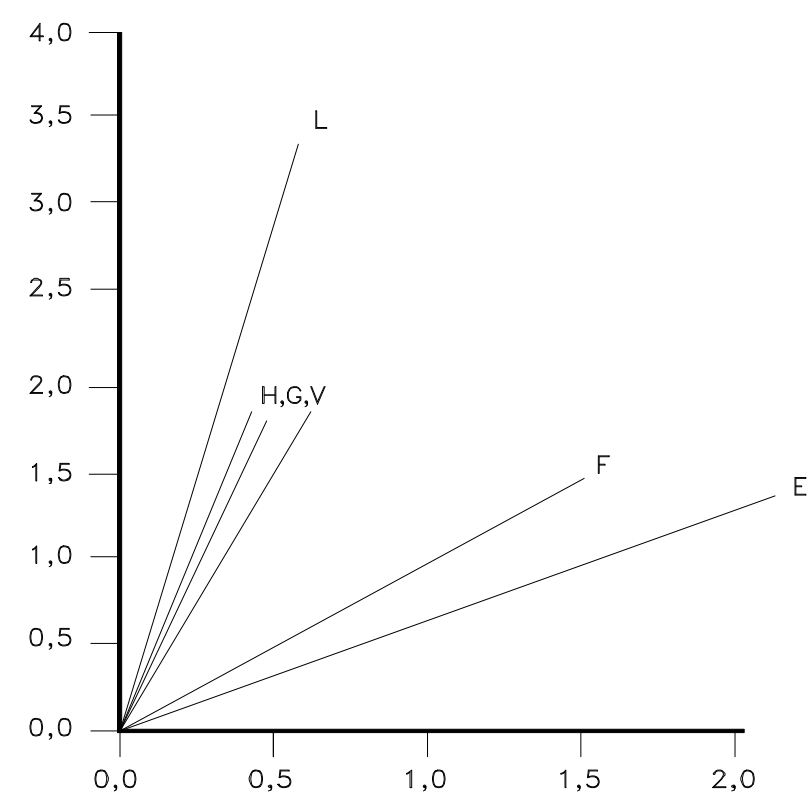

FIGURA 3.15 - GRÁFICO MOMENTO X DESLOCAMENTO SEGUNDO O TIPO DE CONECTOR (PFEIFER \& HANSON, 1965) 
Segundo PFEIFER \& HANSON (1965), as nervuras oferecem enorme contribuição à composição entre as placas de concreto. Em umas das séries de ensaios buscou-se estudar uma disposição de nervuras que proporcionasse maior área disponível de isolante, mantendo-se a mesma rigidez lateral, como mostra a fig.3.16. Os resultados dos ensaios realizados são mostrados no gráfico da fig.3.17.

Para uma melhor avaliação da resistência de painéis tipo sanduíche em relação à formação de fissuras, de acordo com o tipo de conector utilizado, PFEIFER \& HANSON (1965) propuseram coeficientes de segurança para painéis submetidos à ação de vento inferior a $1,0 \mathrm{kN} / \mathrm{m}^{2}$, como mostra a tabela 3.3 .

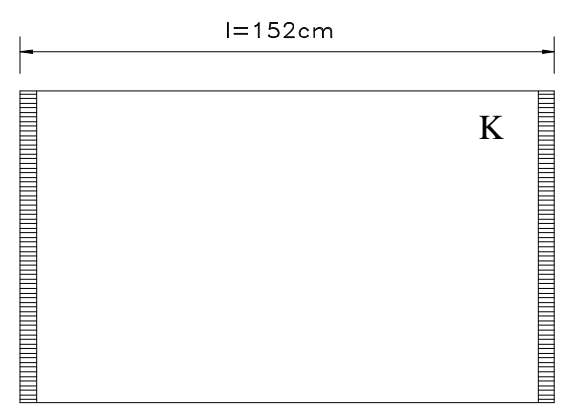

(a) 5\% de área

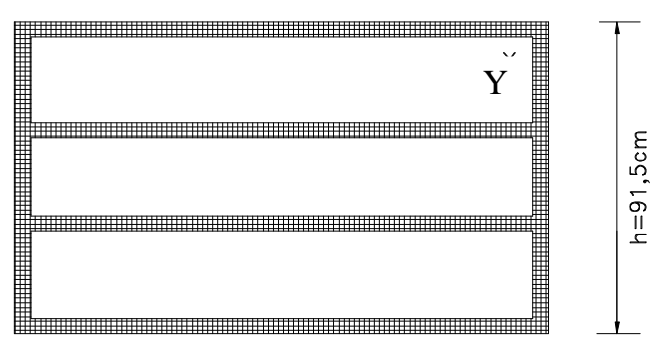

(b) $21 \%$ de área

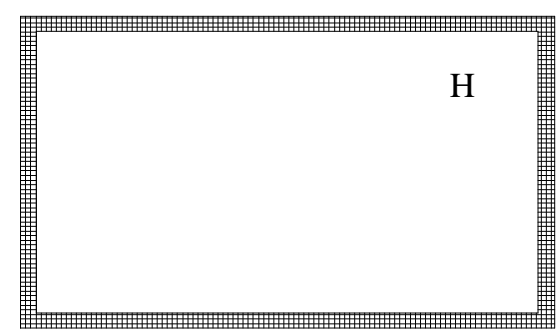

(c) $15 \%$ de área
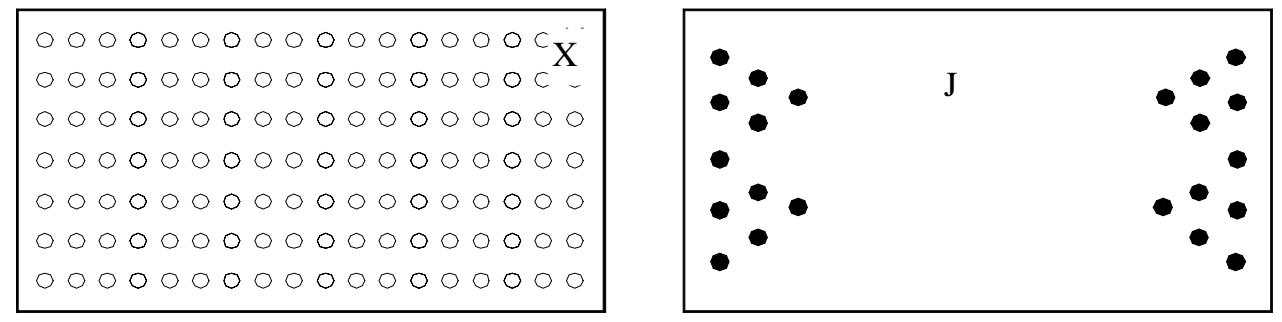

FIGURA 3.16 - TIPOS DE PAINÉIS NERVURADOS ESTUDADOS POR PFEIFER \& HANSON (1965) 


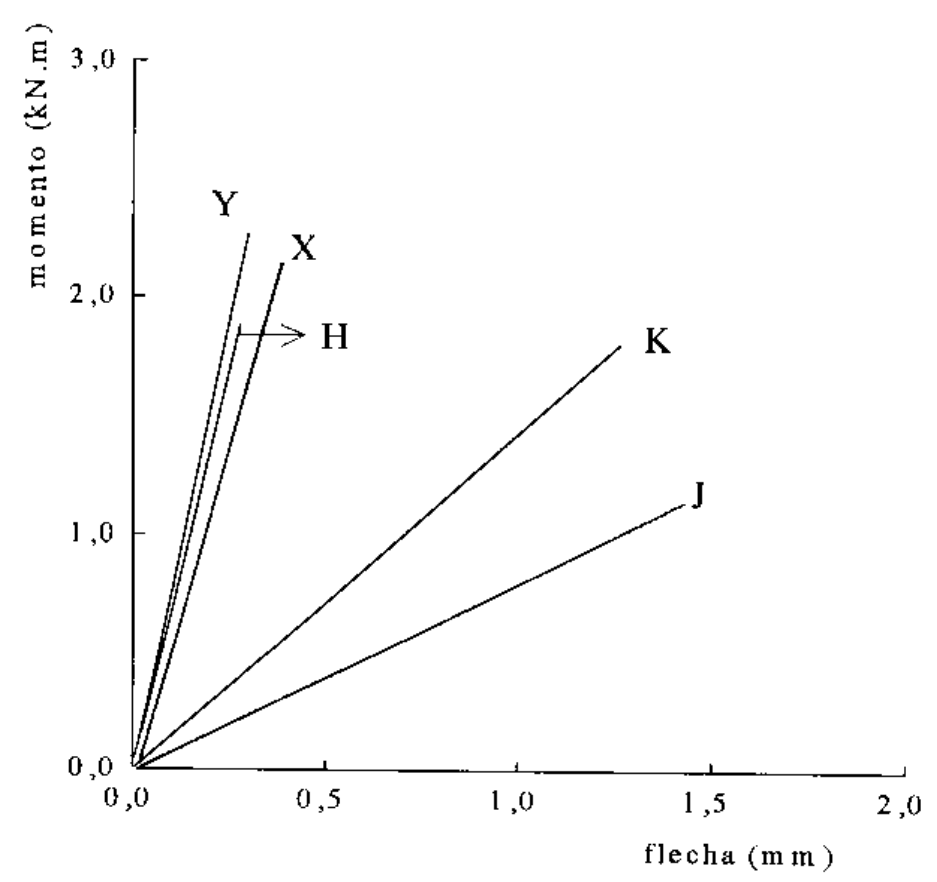

FIGURA 3.17 - GRÁFICO MOMENTO X DESLOCAMENTO DE PAINÉIS NERVURADOS (PFEIFER \& HANSON, 1965)

TABELA 3.3 - Coeficientes de segurança para fissuração em painéis sanduíche submetidos à ação de vento

\begin{tabular}{ccc}
\hline $\begin{array}{c}\text { Comprimento do painel } \\
(\mathrm{cm})\end{array}$ & $\begin{array}{c}\text { Conector de concreto } \boldsymbol{o u} \text { de } \\
\text { metal }\end{array}$ & $\begin{array}{c}\text { Conector de concreto } \underline{\boldsymbol{e}} \text { de } \\
\text { metal }\end{array}$ \\
\hline 244 & 4,0 & 5,8 \\
305 & 2,5 & 3,6 \\
366 & 1,7 & 2,5 \\
\hline
\end{tabular}

É importante observar que a procura do entendimento da transferência de esforços de uma placa resistente para outra foi motivo de investigação para todos os estudos apresentados. Esta preocupação com a conexão entre as placas resistentes, seja ela feita pelo próprio núcleo ou por meio de conectores ou nervuras, deve-se ao fato de que um bom funcionamento estrutural depende de uma eficiente ligação entre as placas. Em quase todos os ensaios realizados verificou-se que uma percentagem da transferência de esforços era devida ao núcleo, que apesar de ser pouco resistente, possui grande área de contato, colaborando para a transferência de cisalhamento. 


\subsection{GRADIENTE DE TEMPERATURA E RETRAÇÃO}

Em seções tipo sanduíche, as faces podem estar sujeitas a variações volumétricas distintas. Essas variações volumétricas podem estar associadas a:

- Gradiente de temperatura entre a duas placas, quando o núcleo possui elevada resistência térmica, e as placas estão sujeitas a ambientes diferentes;

- Retração diferenciada entre as faces, quando estas estão sujeitas a umidades diferentes.

Se a diferença de temperatura e de umidade entre as duas faces resistentes da seção composta for nula ou muito pequena, então a variação volumétrica pela temperatura e retração será a mesma para ambas as faces, que trabalhão juntas, com uma pequena movimentação entre si. De outra maneira, à medida que a variação volumétrica se tornar diferente entre as duas faces, o efeito será a flexão do elemento.

Quando a seção é do tipo não-composto, onde as faces são interligadas por conectores flexíveis, as deformações das placas pela variação volumétrica são independentes. Quando os conectores não são flexíveis, então as placas trabalham em conjunto.

A quantificação da flexão pela retração diferenciada não é muito precisa, envolvendo uma quantidade de variáveis maior que a da flexão térmica. Pode-se estimar o efeito da retração considerando-se esta como uma variação de temperatura, mediante uso dos parâmetros da NBR-7197 (1989).

O cálculo de deformações e de tensões, em elementos compostos sujeitos a um gradiente de temperatura entre as faces, pode ser feito pelo processo apresentado por EINEA et al (1991). No caso de elementos com seção sanduíche parcialmente compostos, o cálculo das tensões através desse processo está a favor da segurança, já que a interação não é total. A seguir estão as hipóteses consideradas e as etapas de cálculo.

\subsubsection{Hipóteses de cálculo}

No cálculo de seções compostas submetidas a gradiente de temperatura, são admitidas as seguintes hipóteses:

- Seções planas permanecem planas após a flexão; 
- O material é considerado homogêneo, com relação constante entre tensão e deformação;

- A variação de temperatura se dá em regime permanente de transmissão de calor.

\subsubsection{Etapas de cálculo}

Os efeitos do gradiente de temperatura são calculados em quatro etapas, detalhadas a seguir:

a) Sem considerar a composição entre as placas, permite-se que cada uma se deforme livremente sob a ação a que cada face está exposta. Para que isto ocorra, a resistência ao cisalhamento proporcionada por conectores ou nervuras deve ser desprezada, como mostra a fig.3.18a. A deformação $\varepsilon=\mathrm{C} \Delta \mathrm{T}$, onde $\mathrm{C}$ é o coeficiente de expansão térmica e $\Delta \mathrm{T}$ é a diferença de temperatura entre as faces, considerada constante ao longo da espessura (fig.3.19). A distribuição de deformações é idêntica ao diagrama do $\Delta \mathrm{T}$ do concreto ou da argamassa, suposta uniforme por simplificação. Neste estágio, a reação de apoio é zero. Diagramas de temperaturas variáveis ao longo da espessura das placas devem ser tratados similarmente. Quando as placas de concreto ou de argamassa são de pequena espessura (em torno de $4 \mathrm{~cm}$ ), é razoável considerar-se constante a temperatura ao longo das placas, e que toda variação de temperatura ocorre ao longo da espessura do núcleo. Segundo TEIXEIRA (1999), este procedimento é justificável pela grande diferença entre os coeficientes de transmissão de calor do concreto e do material do núcleo, por exemplo o EPS.

b) Compensar a deformação $\varepsilon_{t}$ com um par de forças opostas $F_{R}$ (fig.3.18b). Tais forças devem produzir uma deformação do mesmo valor da deformação térmica, com sinal trocado. A tensão ao longo do painel e a força $F_{R}$ são dadas por:

$$
\begin{gathered}
\sigma_{t}=-\varepsilon_{t} E_{c} \\
F_{R}=\sigma_{t} b t=-(C \Delta T) b t E_{c}
\end{gathered}
$$

onde:

$\sigma_{\mathrm{t}}=$ tensão pela deformação térmica;

$\varepsilon_{\mathrm{t}}=$ deformação térmica na face; 
$\mathrm{E}_{\mathrm{c}}=$ módulo de elasticidade do concreto ou da argamassa;

$F_{R}=$ resultante da tensão necessária para produzir a deformação $\varepsilon_{t}$;

$\mathrm{b}=$ largura do elemento;

$\mathrm{t}=$ espessura das faces.

c) A restrição criada no passo $b$ (par de forças $F_{R}$ ) restaura a compatibilidade das deformações. Porém, nesta situação não há o equilíbrio. Para compensar a restrição externa, deve ser aplicado um par de forças opostas, como mostra a fig.3.18c. Neste passo, as forças são aplicadas para "reconectar" a seção sanduíche. Se o elemento for um painel de seção composta e simplesmente apoiado, o momento $\mathrm{M}=\mathrm{F}_{\mathrm{R}}$.e restaurará o equilíbrio estático, sendo $e$ a excentricidade da força $F_{R}$. Em seções tipo sanduíche parcialmente compostas, deve ser feita uma análise mais cuidadosa para levar em conta o movimento relativo entre as faces.

d) Combinar os resultados dos passos de a até c para obter os diagramas finais de tensões e de deformações, como mostra a fig.3.18d. O deslocamento no meio do vão pelo gradiente térmico é dado por um sistema equivalente, com momentos aplicados na extremidade:

$$
\delta=\frac{\mathrm{ML}^{2}}{8 \mathrm{E}_{\mathrm{c}} \mathrm{I}_{\mathrm{c}}}=\frac{(\mathrm{C} \Delta \mathrm{T}) \mathrm{bteL}^{2}}{8 \mathrm{I}_{\mathrm{c}}}
$$

onde:

$\delta=$ deslocamento no meio do vão;

$\mathrm{M}=$ momento equivalente;

$\mathrm{L}=$ comprimento do elemento;

b = largura da seção;

$I_{c}=$ momento de inércia da seção sanduíche. 


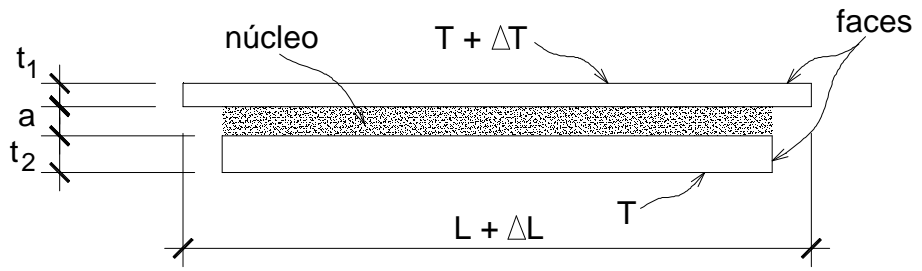

( a )

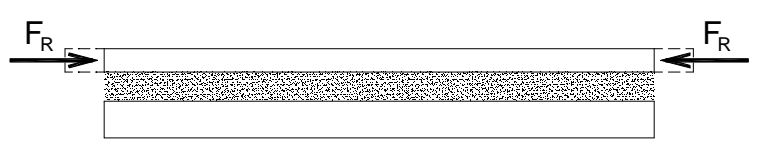

( b )
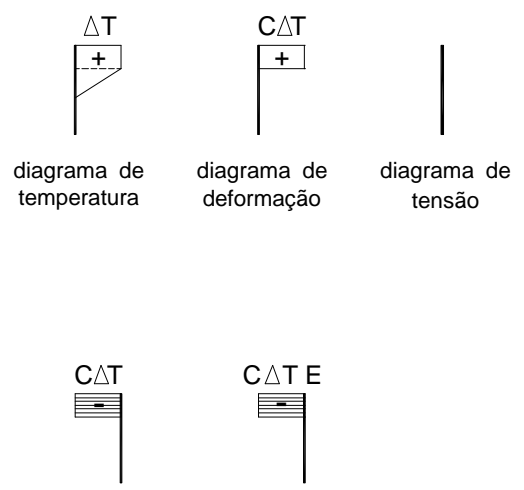

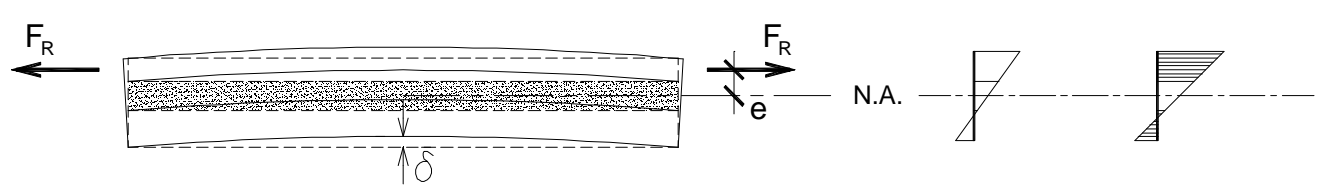

(c)
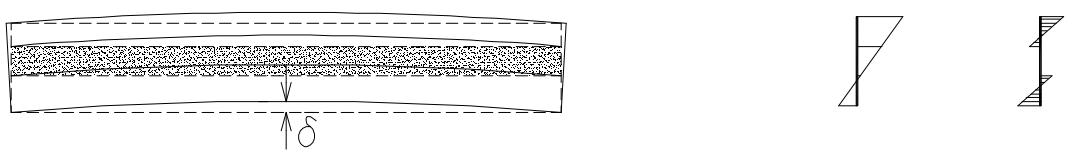

(d)

FIGURA 3.18 - ETAPAS DE CÁLCULO PARA UM GRADIENTE DE TEMPERATURA (EINEA ET AL., 1991)
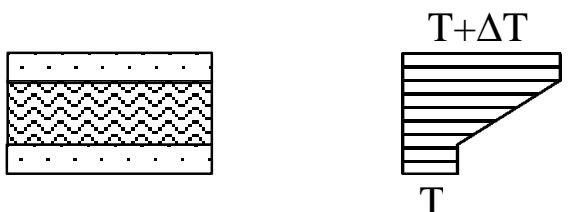

FIGURA 3.19 - VARIAÇÃO DE TEMPERATURA ATRAVÉS DE UMA SEÇÃO TIPO SANDUÍCHE (EINEA ET AL., 1991) 


\section{ARGAMASSA E MICROCONCRETO PROJETADOS}

\subsection{DEFINIÇÕES E APLICAÇÕES}

O (ACI) 506(1994) define CONCRETO PROJETADO ("shotcrete") como sendo uma "argamassa ou concreto pneumaticamente projetado em alta velocidade sobre uma superfície". A definição do ACI é sucinta e abrangente, pois possibilita a utilização ou não de agregados graúdos e a escolha do processo de projeção.

A empresa americana Cement Gun Company, da cidade de Allentown, utilizou em 1911 o termo "gunite" para uma mistura seca de agregados finos e cimento, umedecido no bico da mangueira de projeção e pneumaticamente projetado sobre uma superfície. Nesse mesmo ano utilizou a gunite para consolidar os taludes de Culebra-Cut, atualmente Gaillard-Cut, na linha divisória de águas do canal do Panamá.

Muitas outras definições de concreto projetado podem ser encontradas na literatura. Em todas elas verifica-se a preocupação de destacar a alta velocidade de projeção, como meio para se garantir a autocompactação. No Brasil, a Associação Brasileira de Normas Técnicas (ABNT), através da Comissão de Estudos CE 18:306, apresentou uma boa definição, que contempla todos estes aspectos: "O concreto projetado é um concreto com dimensão máxima do agregado superior a 4,8mm, transportado através de uma tubulação e projetado, sob pressão, a elevada velocidade, sobre uma superfície, sendo compactado simultaneamente”.

$\mathrm{O}$ termo shotcrete foi introduzido pela American Railway Engineering Association, por volta de 1930, e tem aceitação nacional nos EUA. Na Inglaterra, o concreto projetado foi denominado sprayed concrete, na Alemanha spritzbeton, na França beton projeté e na Espanha hormigón proyectado. 
O concreto projetado é muito competitivo nas aplicações de estabilização de taludes, revestimento de túneis, canais, galerias, recuperação estrutural e quaisquer obras em que a superfície possa funcionar como anteparo (fôrma) para o material lançado. A versatilidade do concreto projetado permite, segundo FIGUEIREDO (1992), ser empregado em 40 diferentes aplicações, entre as quais revestimentos, obras subterrâneas, contenção de taludes, reparos e reforços estruturais, impermeabilizações, chaminés de fornos, elementos autoportantes e formas livres (esculturas).

As principais vantagens do concreto projetado são eliminação de fôrmas para moldagem do concreto, rapidez de lançamento e pouca mão-de-obra no processo executivo, uma vez que lançamento e adensamento constituem uma única operação.

O concreto projetado pode substituir o concreto convencional em vários casos, sendo mais indicado em situações como colocação de fôrmas muito trabalhosa, desejo de redução de custos de fôrma, difícil acesso ao local de moldagem, necessidade de pequenas espessuras ou espessuras variáveis etc. Entre as vantagens do concreto projetado encontra-se sua ótima aderência a vários tipos de materiais. Porém, ele é mais susceptível a falhas, quando houver grandes concentrações de armadura.

\subsection{PROCESSOS DE PROJEÇÃO DE CONCRETO}

$\mathrm{Na}$ projeção de concreto empregam-se basicamente dois processos: via seca (dry-mix) e via úmida (wet-mix). A escolha do mais adequado é definida pelo espaço para lançamento em obra, volume a ser projetado e características do concreto especificado. O método via seca é o mais empregado, por utilizar equipamentos compactos, de fácil acesso em obras e pela grande variedade de aplicações. Mais moderna e também de emprego mais recente no Brasil, a projeção via úmida tem utilização em obras de grandes volumes, como revestimentos de túneis e obras de arte. 


\subsubsection{Processo via seca}

No processo via seca, a mistura de agregado e cimento é conduzida por ar comprimido através de uma mangueira até o bico de projeção. No mangote, a mistura recebe água por meio de outra mangueira, e o concreto é jateado sobre a superfície, com alto poder de compactação. A saída de água é controlada pelo mangoteiro, que deve ter treinamento específico. A qualidade do concreto no processo via seca depende em grande parte deste profissional. Dosagens excessivas de água podem comprometer a aderência do concreto. Ao contrário, água a menos pode gerar grande quantidade de pó na área de projeção e elevada reflexão, tornando o ambiente insalubre. Os procedimentos e a qualificação do mangoteiro são regidos pela NBR 13597/96.

FIGUEIREDO (1992) ressalta a existência de um terceiro processo de projeção no Brasil, denominada via semi-úmida, que consiste em um caso especial de via seca, pois utiliza o mesmo equipamento, modificando-se apenas o local de entrada de água da mistura: além da entrada de água no bico, há outra que ocorre a alguns metros antes, através de um anel pré-umidificador, como mostra o esquema da fig.4.1.

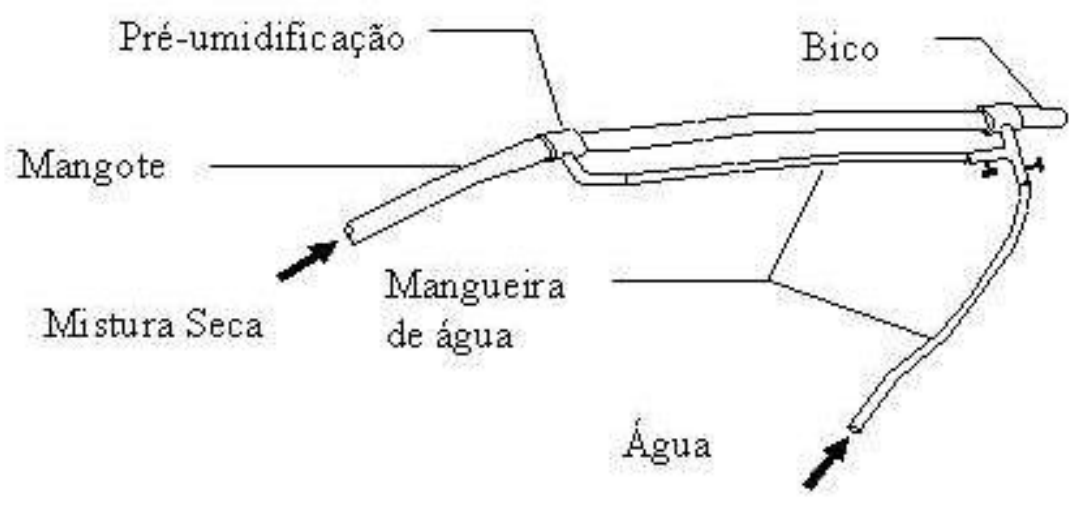

FIGURA 4.1 - ESQUEMA DO SISTEMA DE PRÉ-UMIDIFICAÇÃO (FIGUEIREDO, 1992)

A produtividade média dos equipamentos via seca varia entre 3 e $6 \mathrm{~m}^{3} / \mathrm{h}$. O concreto geralmente é especificado por consumo de cimento, em média de $450 \mathrm{~kg} / \mathrm{m}^{3}$, e pela resistência característica à compressão $\left(\mathrm{f}_{\mathrm{ck}}\right)$. Geralmente são executadas camadas com até $10 \mathrm{~cm}$ de espessura, em projeções sucessivas. 


\subsubsection{Processo via úmida}

A característica principal do processo via úmida é que todos os componentes, inclusive a água, são misturados inicialmente. Isso garante maior uniformidade do concreto do que no processo via seca, pois a dosagem de água não é feita pelo mangoteiro. A mistura é introduzida na câmara do equipamento de projeção e transportada pneumaticamente ou por bomba de pistão. Injeta-se ar comprimido ou, no caso de transporte pneumático, ar de outro compressor junto ao bico, e o material é projetado em alta velocidade, garantindo sua compactação.

Este processo tem largo emprego no revestimento de túneis e obras de arte de grande volume. Caracteriza-se, na maioria das vezes, pelo emprego de equipamentos com braço mecânico (robô).

Os equipamentos da via úmida têm maior capacidade para projeção, em média de 5 a $20 \mathrm{~m}^{3} / \mathrm{h}$, e o concreto é especificado pela resistência característica à compressão $\left(\mathrm{f}_{\mathrm{ck}}\right)$. Geralmente são utilizados concretos entre 15 e $30 \mathrm{MPa}$, mas há registros de obras no Brasil com até $45 \mathrm{MPa}$. O abatimento adequado do concreto projetado por via úmida deve variar entre 70 e $150 \mathrm{~mm}$. É possível executar camadas de até $30 \mathrm{~cm}$ de espessura, desde que feitas em etapas sucessivas.

\subsection{CONCEITOS SOBRE ARGAMASSA E MICROCONCRETO}

Segundo a norma brasileira que trata do projeto de argamassa armada (NB1259), a argamassa é definida como "mistura homogênea composta de cimento Portland, agregado miúdo e água, podendo eventualmente conter adições que melhorem suas propriedades".

Segundo CUNHA (1991), na definição de microconcreto, não existe consenso de opiniões no meio técnico-científico, e dentre as diversas referências bibliográficas que definem o microconcreto observam-se divergências sobre suas diferenças em relação à argamassa e suas semelhanças com o concreto. Na verdade, é a composição granulométrica o que mais suscita questões em torno dos microconcretos, por se acreditar ser ela exatamente o ponto que a destaca de uma argamassa e de um concreto. 
O microconcreto pode ser entendido como uma espécie de argamassa dosada convenientemente para atingir boas qualidades, tanto em termos de propriedades físicas como em termos de durabilidade.

Pode-se dizer que o microconcreto é um concreto de granulometria fina, com agregado miúdo (diâmetro máximo característico $\leq 4,8 \mathrm{~mm}$ ) e frações finas de agregado graúdo (diâmetro máximo característico $\leq$ 9,5 mm), sendo uma argamassa com características melhoradas, utilizado como material especial para modelos estruturais, sendo ainda empregado no campo de aplicação de pré-moldados e na préfabricação de peças para os mais variados fins.

Sobre a questão levantada quanto aos termos "microconcreto" e "argamassa", CUNHA (1991) ressalta que:

"A idéia de se efetuar uma melhor composição de agregados para argamassas parece estar expandindo no meio técnico-científico e o problema da terminologia adequada para este material (argamassa ou microconcreto) parece irrelevante quando as tentativas de se aprimorar a tecnologia de um dado material apontam para o mesmo caminho, ou seja, obter um material de boa qualidade e que atenda bem ao fim a que se presta”.

\subsection{PROJEÇÃO DA ARGAMASSA}

A projeção da argamassa pode ser feita manualmente (pelos métodos tradicionais de emboçamento) ou mecanicamente, feita pelo processo via úmida, no qual são utilizados equipamentos mais compactos que os utilizados para o concreto. Os materiais são pré-misturados em uma bomba e projetados já em estado plástico.

A técnica de projeção manual da argamassa, que utiliza como ferramenta principal a colher de pedreiro, possui baixa produtividade, e a durabilidade do revestimento não é confiável, devido à maneira com que é executada. O processo manual é semelhante ao empregado na aplicação do emboço (revestimento) de paredes de alvenaria. Tomando-se certos cuidados na execução, esta técnica pode ser utilizada como uma alternativa, na falta de equipamentos de projeção.

Como prova da aplicabilidade da técnica de projeção manual, a empresa CÓDIGO ENGENHARIA construiu uma casa em Cotia - SP (fig.4.2), onde foram 
empregados painéis tipo sanduíche. No local não havia possibilidade de utilização de equipamentos de projeção, pela falta de energia elétrica. Optou-se então por aplicar manualmente a argamassa.
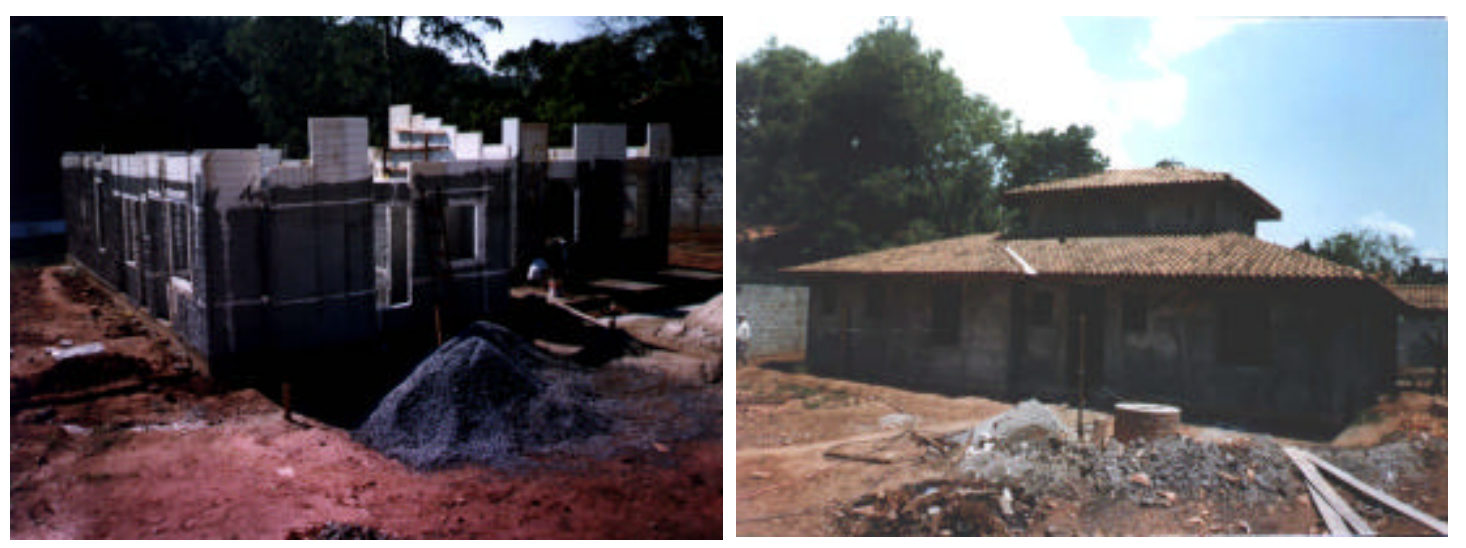

FIGURA 4.2 - CASA CONSTRUÍDA PELA CÓDIGO ENGENHARIA EM COTIA-SP

A projeção mecânica da argamassa utiliza geralmente equipamentos dotados de uma bomba de pistão, compressor e acessórios para lançamento. A produtividade média de uma bomba de pistão é de cerca de $2 \mathrm{~m}^{3} /$ hora. Segundo a revista TÉCHNE (1999), considerando-se uma parede e um revestimento de $3 \mathrm{~cm}$, pode-se executar até $65 \mathrm{~m}^{2}$ de projeção por hora. $\mathrm{O}$ processo de projeção da argamassa não elimina as etapas de sarrafeamento e desempenamento da superfície do revestimento, e sua produtividade dependerá da experiência dos pedreiros.

Para a boa qualidade dos revestimentos executados com argamassa projetada deve-se estar atento, sobretudo, às condições do substrato. As características particulares de cada substrato para atrair a água serão determinantes da resistência e da aderência da argamassa. A utilização de aditivos ou materiais muito abrasivos que possam alterar demasiadamente as características da argamassa podem comprometer o bom funcionamento dos equipamentos. As argamassas podem receber polímeros, corantes e aditivos especiais para cura e controle do tempo de pega.

Os equipamentos utilizados na aplicação de argamassa projetada possuem alta produtividade. Por este motivo é necessária uma infra-estrutura na obra, que atenda a este ritmo de produção. Vários equipamentos estão disponíveis comercialmente para projeção de argamassa; por exemplo: MINI da TURBOSOL, ST-45 da MAYCO, CP15-SU da ESTE, B-25 da BETOMAQ e P-13 DA PUTZMEISTER. 
Os riscos de patologia da argamassa projetada são praticamente os mesmos da executada manualmente. Quando aplicada corretamente, os índices de reflexão são pequenos. O maior ou menor desperdício se dá na etapa de sarrafeamento, em função da habilidade do profissional que executa o acabamento.

A argamassa pode ainda ser projetada por meio da caneca de projeção (fig.4.3). A caneca é bastante utilizada na construção de painéis autoportantes para edificações. Com esta técnica obtêm-se uma boa produtividade e compactação razoável da argamassa.

A fig.4.3 mostra uma caneca de projeção que consiste em um recipiente de aproximadamente 5 litros, onde é depositada a argamassa. Através de orifícios próximos ao fundo do recipiente, o ar comprimido é liberado, projetando a argamassa, que sai por três furos localizados na frente da caneca, próximo ao fundo, conforme mostra a fig.4.4. A caneca é acoplada a um compressor de ar, que deve fornecer, para um bom funcionamento, uma pressão de $120 \mathrm{lb}$.

O processo de projeção através da caneca é simples: cada vez que a caneca se esvazia, ela é novamente preenchida manualmente, e, acionando-se o ar comprimido, a argamassa é projetada sobre a superfície desejada. A caneca deve ser posicionada a um distância de aproximadamente $20 \mathrm{~cm}$ da superfície a ser projetada (fig.4.5).

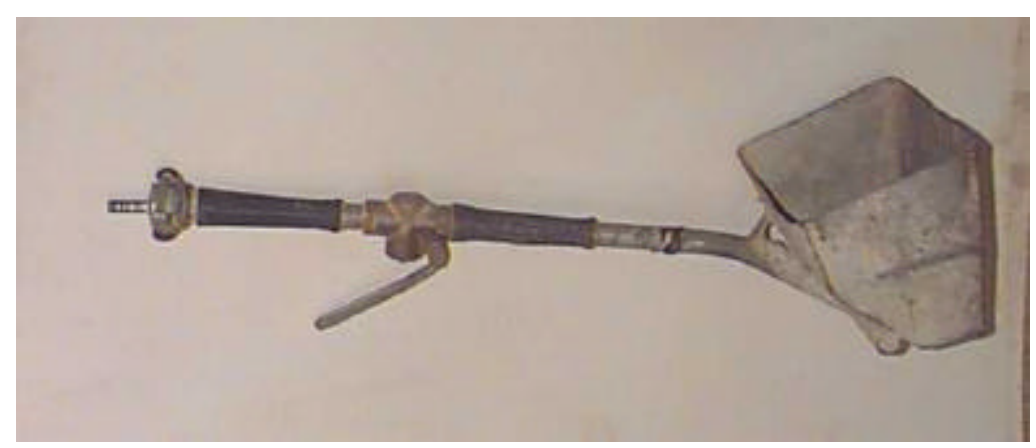

FIGURA 4.3 - CANECA DE PROJEÇÃO 


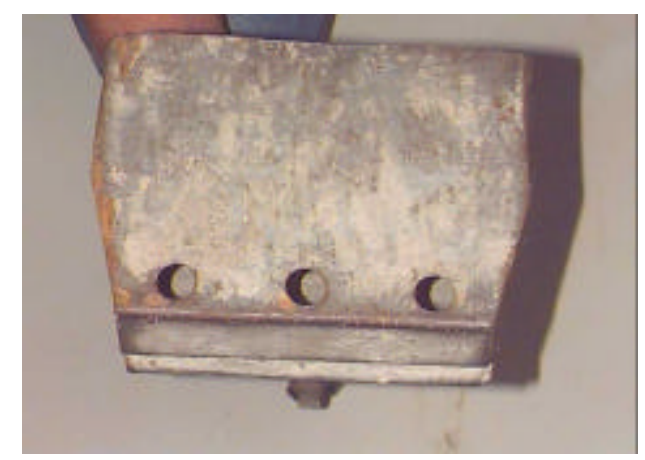

FIGURA 4.4 - DETALHES DOS FUROS DE SAÍDA DA ARGAMASSA

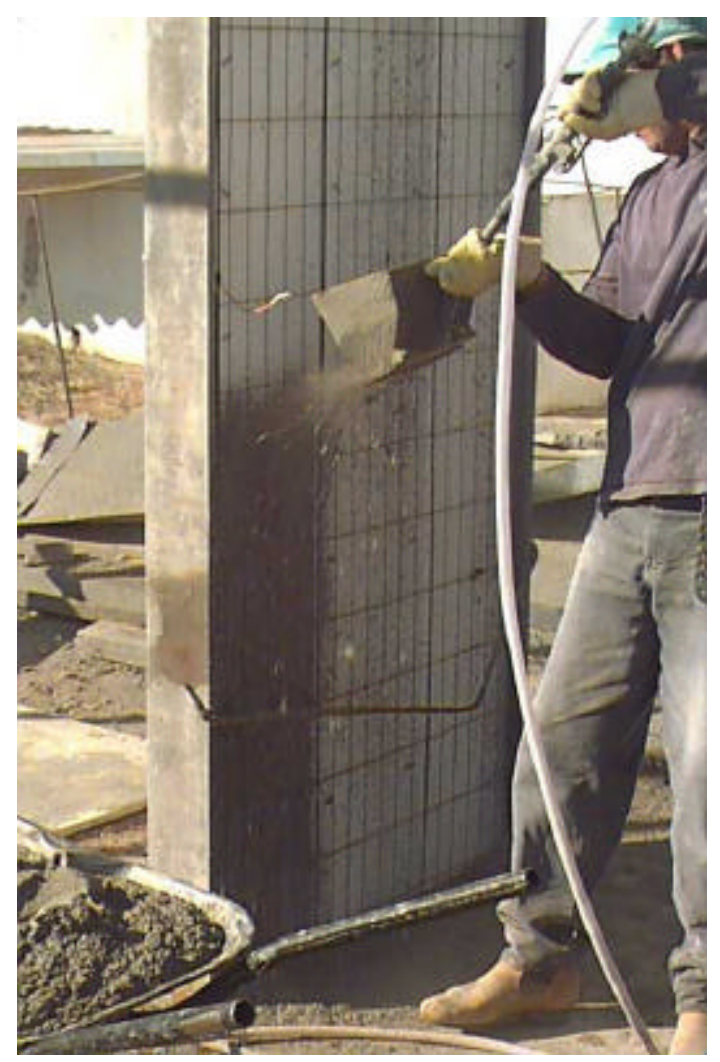

FIGURA 4.5 - PROJEÇÃO COM A CANECA

Com a utilização da caneca de projeção podem-se executar até $20 \mathrm{~m}^{2} / \mathrm{hora}$, considerando um revestimento de 1,5 a $2 \mathrm{~cm}$. Com este processo, o índice de reflexão varia de 5 a $10 \%$, em função do substrato. Como no caso da projeção por meio de equipamentos dotados de bomba de pistão, a utilização da caneca para projeção da argamassa não elimina as etapas de sarrafeamento e desempenamento da superfície do revestimento, e sua produtividade dependerá também da experiência dos pedreiros. 


\subsection{CIMENTO}

De um modo geral, qualquer tipo de cimento Portland é adequado para o uso como aglomerante em concreto projetado. Recomenda-se, sempre que possível, o uso do cimento Portland comum (KLOBLER, 1966).

O uso de cimentos de endurecimento rápido e pega controlada, em concreto projetado, dispensam o uso de aditivos aceleradores de pega, em aplicações onde é exigida uma rápida evolução das resistência iniciais.

Em geral, a finura recomendada na literatura varia de 3500 a $6000 \mathrm{~cm}^{2} / \mathrm{g}$. Segundo PRUDÊNCIO (1993), cimentos muito finos apresentam maior reatividade inicial e podem gerar problemas de entupimentos mais frequentes nos equipamentos de via seca e exigir mais água (ou mais plastificantes) para uma dada consistência, nos casos de concretos projetados por via úmida.

\subsection{AGREGADOS}

Os agregados são materiais granulares com forma e volume variáveis que, para o uso em obras de Engenharia em geral, possuem dimensões e propriedades adequadas. Com aplicação muito diversificada, os agregados se prestam, entre outras coisas, para a confecção de argamassas e concretos, desempenhando relevantes papéis dos pontos de vista técnico e econômico. O agregado pode, além de limitar a resistência, influenciar fortemente na durabilidade e no desempenho estrutural do concreto.

O fato de se exigir que o agregado ocupe o maior volume relativo possível é, em primeiro lugar, de caráter econômico, visto que o agregado tem custo menor que a pasta de cimento, mas existem razões técnicas para que se evitem misturas com quantidade muito grande de agregados.

Segundo o seu tamanho, os agregados se dividem em agregados miúdos e graúdos. O agregado miúdo corresponde àquele cujos grãos passam pela peneira de abertura nominal 4,8mm, e o agregado graúdo fica retido nesta mesma peneira, de acordo com a NBR 7211(1983). Um aspecto importante na composição dos concretos consiste na combinação de agregados miúdos e graúdos para obter uma granulometria adequada. 
Para concretos projetados não existe um consenso quanto à granulometria ideal. As divergências são basicamente as que se referem à dimensão máxima característica do agregado graúdo.

O ACI 506-R-40 (1994) especifica três faixas granulométricas recomendadas para agregados destinados a concreto projetado, indicadas na tabela 4.1.

TABELA 4.1 - Valores-limites para curvas granulométricas (agregado total) utilizados em concreto projetado

\begin{tabular}{|c|c|c|c|}
\hline \multirow{2}{*}{$\begin{array}{c}\text { Abertura da peneira } \\
(\mathbf{m m})\end{array}$} & \multicolumn{3}{|c|}{ Percentagem Acumulada de Material Passante } \\
\cline { 2 - 4 } & Graduação № $\mathbf{1}$ & Graduação No $\mathbf{~}$ & Graduação № 3 \\
\hline 19 & - & - & 100 \\
\hline 12 & - & 100 & $80-95$ \\
\hline 10 & 100 & $90-100$ & $70-90$ \\
\hline 4,75 & $95-100$ & $70-85$ & $50-70$ \\
\hline 2,4 & $80-100$ & $50-70$ & $35-55$ \\
\hline 1,2 & $50-85$ & $35-55$ & $20-40$ \\
\hline 0,6 & $25-60$ & $20-35$ & $10-30$ \\
\hline 0,3 & $10-30$ & $8-20$ & $5-17$ \\
\hline 0,15 & $2-10$ & $2-10$ & $2-10$ \\
\hline
\end{tabular}

Nas argamassas também é interessante a combinação de agregados miúdos com várias dimensões, devendo-se lembrar que a adição de mais grãos com dimensões maiores pode favorecer bastante a diminuição do consumo de pasta. Quanto maiores as partículas de agregados, menor a área a ser molhada por unidade de massa. Assim, estendendo-se a granulometria do agregado a um tamanho máximo maior, reduz-se a demanda de água do concreto, de modo que, para uma mesma trabalhabilidade e mesmo teor de cimento, pode ser reduzida a relação água-cimento, com um conseqüente aumento da resistência.

As características da estrutura do agregado dependem do tamanho das partículas, da sua forma e granulometria e, em menor grau, do tamanho e da forma do recipiente que contém o agregado.

A granulometria exerce forte influência sobre a qualidade das argamassas e dos concretos, em especial no que se refere à compacidade e à resistência aos esforços mecânicos. 
Pode-se definir uma granulometria ótima como aquela correspondente a um mínimo consumo de cimento, para uma desejada consistência e uma relação águacimento pré-fixada. NEVILLE (1982) faz a seguinte observação: "Como a resistência de um concreto completamente adensado, com uma dada relação águacimento, é independente da granulometria do agregado, a granulometria é, em primeira aproximação, importante até o ponto em que influencia a trabalhabilidade. Como, no entanto, a obtenção da resistência correspondente a uma determinada relação água-cimento exige adensamento completo, o que só pode ser conseguido com uma mistura suficientemente trabalhável, é necessário que se prepare uma mistura que possa ser adensada no máximo possível com um quantidade de energia razoável".

Embora não existam granulometrias ideais, certas características são desejadas para uma boa curva granulométrica, podendo-se executar concretos e argamassas com granulometrias diferentes. Alguns dos fatores que atuam sobre uma granulometria desejada são a área superficial dos agregados, o volume relativo ocupado pelos agregados, a trabalhabilidade da mistura e a tendência à segregação.

A superfície específica de um agregado é definida pela relação da somatória da superfície dos grãos e o seu volume. A superfície específica dá uma indicação da água de molhagem, o que é de grande importância na consistência e, portanto, na trabalhabilidade do concreto. Para uma dada consistência (para uma trabalhabilidade e relação água-cimento dadas), quanto menor a superfície específica, menor a quantidade de água necessária, o que significa que, quanto maior é a granulometria, mais pobre é a mistura. No entanto, uma mistura muito pobre não será coesiva sem a quantidade suficiente de finos, e por isso deve-se ter o cuidado de atentar para este fato ao se trabalhar com granulometrias maiores.

Em relação ao volume relativo ocupado pelos agregados nas misturas de concretos e argamassas, por razões econômicas utiliza-se o maior volume possível de agregado para acarretar uma diminuição do consumo de pasta, o que faz aumentar a resistência. Porém, é necessário um excesso de pasta ou argamassa, além da quantidade que preenche os vazios da areia e do agregado graúdo. Por sua vez, a pasta é a grande responsável pela retração das argamassas e dos concretos, que acaba 
por afetar a durabilidade do material, fazendo aparecer fissuras indesejáveis nas peças executadas.

Segundo NEVILLE (1982), o agregado é o material que tem maior influência sobre a retração hidráulica de pastas, e ele acrescenta que não é o tamanho nem a granulometria do agregado em si que influenciam na retração, mas sim o fato de um agregado maior permitir o emprego de uma mistura mais pobre, o que resulta numa menor retração. Nos casos das argamassas, onde a retração é maior do que nos concretos, a diminuição do consumo de pasta com o aumento de agregado na mistura parece favorável à questão da durabilidade dos materiais, com a diminuição da retração. Deve-se procurar alcançar o equilíbrio entre a economia de pasta para diminuição da retração e a quantidade de pasta suficiente para promover o envolvimento total dos grãos de agregado, bem como favorecer a trabalhabilidade.

A ausência de segregação é outro requisito importante na execução de concretos e argamassas. Pode-se definir segregação como a separação dos componentes da mistura, prejudicando a uniformidade da distribuição. Em geral, nas argamassas, a segregação quase não é observada. Nos concretos, uma das causas da segregação é a diferença de tamanho das partículas do agregado, o que pode ser amenizado com o estudo de uma adequada granulometria, além dos cuidados de manuseio da mistura, durante a execução.

No caso de se fixarem as proporções de uma mistura e a quantidade de água, a consistência fica dependente do agregado e de suas características correlatas, seja a dimensão máxima característica, granulometria, forma ou textura. É essencial o conhecimento prévio dos agregados disponíveis para se fazer a dosagem de concretos e argamassas. A granulometria, entretanto, deve ser considerada juntamente com a relação água-cimento, pois a variação desta última para a granulometria fixa faz variar a consistência das misturas. Para uma trabalhabilidade máxima, necessita-se de uma granulometria tanto mais fina quanto maior for a relação água-cimento.

Verifica-se que a influência da granulometria sobre a dosagem de concretos e argamassas acaba por determinar o estudo criterioso da combinação mais adequada de agregados, para que, ao lado de outros fatores atuantes na dosagem, se consiga alcançar misturas com propriedades desejáveis. 


\subsection{ADITIVOS}

A ASTM C 125 define aditivo como um material, além de água, agregados, cimentos hidráulicos e fibras, empregado como um constituinte do concreto ou argamassa e adicionado na betoneira imediatamente antes ou durante a mistura. A NBR 11768 define os aditivos como produtos que, adicionados em pequenas quantidades a concretos de cimento Portland, modificam algumas de suas propriedades, no sentido de melhor adequá-las a determinadas condições.

Pode-se listar várias finalidades importantes para os quais os aditivos são empregados; por exemplo:

i) Para aumentar a plasticidade do concreto ou argamassa sem aumentar o teor de água;

ii) Reduzir a exsudação e a segregação;

iii) Retardar ou acelerar o tempo de pega;

iv) Acelerar a velocidade de desenvolvimento da resistência nas primeiras idades;

v) Retardar a taxa de evolução de calor e aumentar a durabilidade em condições específicas de calor.

Para argamassas e microconcretos projetados, o aditivo tem primordial importância no que diz respeito à trabalhabilidade, já que é necessária uma mistura com consistência que possibilite uma adequada projeção, sem que seja afetada a resistência.

Os aditivos variam amplamente quanto à composição química, e muitos desempenham mais de uma função. Consequentemente, é difícil classificá-los de acordo com suas funções. As substâncias empregadas como aditivos podem ser divididas, de modo amplo, em dois tipos: aditivos redutores de água e aditivos minerais.

\subsubsection{Aditivos redutores de água}

Os sais solúveis e os polímeros, agentes tensoativos ou outros, são adicionados ao concreto ou argamassa em quantidades muito pequenas, principalmente com o propósito de incorporar ar, tornar plástico o concreto fresco ou controlar o tempo de pega. Com o uso de aditivos plastificantes é possível aumentar 
a fluidez sem aumentar o teor de água, ou reduzir o teor de água, mantendo uma mesma consistência do concreto fresco. Por esta razão, os plastificantes são chamados de aditivos redutores de água.

A ASTM 494, Standard Specification for Chemical Admixtures for Concrete, divide os produtos químicos redutores de água e modificadores de pega nos sete tipos seguintes: Tipo A, redutor de água; Tipo B, retardador; Tipo C, acelerador; Tipo D, redutor de água e retardador; Tipo E, redutor de água e acelerador; Tipo F, redutor de água de alta eficiência, e Tipo G, redutor de água de alta eficiência e retardador. A distinção entre os agentes redutores de água normais (Tipos A, D, E) e os de alta eficiência é que, comparados a uma mistura de concreto de referência com uma dada consistência, os primeiros devem ser capazes de reduzir o consumo de água pelo menos em $5 \%$ e o último em $12 \%$.

Os produtos tensoativos englobam aditivos geralmente empregados para incorporação de ar ou redução de água em misturas de concreto. O aditivo incorporador de ar é definido como um dos constituintes do concreto que é empregado com a finalidade de incorporar ar; o redutor de água é um aditivo que reduz a quantidade de água de amassamento requerida para produzir um concreto com uma dada consistência.

As substâncias tensoativas consistem essencialmente em moléculas orgânicas de cadeia longa, com extremidade hidrófila (que atrai água) e uma hidrófoba (que repele a água). Em tecnologia de concreto, a maior parte dos aditivos aniônicos empregados contém tanto uma cadeia não-polar como uma cadeia com alguns grupos polares. O primeiro atua como incorporador de ar e o segundo como redutor de água. Os tensoativos são adsorvidos nas interfaces ar-água e cimento-água, com uma orientação da molécula que determina se o efeito predominante é de incorporação de ar ou de fluidificação do sistema água-cimento.

Os tensoativos empregados como aditivos incorporadores de ar geralmente consistem em sais de resinas de madeira, materiais proteicos e ácidos graxos e alguns detergentes sintéticos. Os tensoativos empregados como plastificantes são geralmente sais, modificações e derivados de ácidos lignossulfônicos, ácidos carboxílicos hidroxilados e polissacarídeos. Aditivos superplastificantes ou redutores 
de água de alta eficiência consistem em sais sulfonados de melamina ou condensados de naftaleno-formaldeido.

O mecanismo pelo qual ar é incorporado e estabilizado quando um tensoativo é adicionado ao sistema água cimento é descrito por METHA \& MONTEIRO (1994): na interface ar-água, os grupos polares estão orientados em direção à face aquosa, diminuindo a tensão superficial, promovendo a formação de bolhas e neutralizando a tendência das bolhas se juntarem. Na interface sólido-água, onde existem forças diretoras na superfície do cimento, os grupos polares ligam-se ao sólido, com os grupos não-polares orientados para a água, tornando a superfície do cimento hidrófoba, de modo que o ar pode deslocar a água e permanecer ligado às partículas sólidas na forma de bolhas.

Ao contrário dos tensoativos incorporadores de ar, no caso dos plastificantes, o grupo polar aniônico está ligado a uma cadeia de hidrocarboneto polar ou hidrófila. Quando uma pequena quantidade de água é adicionada ao cimento, sem a presença de tensoativos, não se obtém um sistema bem disperso. Primeiro, porque a água possui tensão superficial elevada (estrutura molecular com ligação tipo ponte de hidrogênio). Segundo, as partículas de cimento tendem a se aglomerar ou formar flocos (existem forças de atração entre as arestas, cantos e superfícies, carregados positiva e negativamente, quando os compostos ou minerais cristalinos são finamentes moídos). METHA \& MONTEIRO (1994) descrevem o seu mecanismo de ação: quando um tensoativo com uma cadeia hidrófila é adicionado ao sistema água-cimento, a cadeia polar é adsorvida ao longo da superfície da partícula de cimento, ao invés de orientar uma extremidade não-polar em direção à água. Neste caso, o tensoativo orienta uma extremidade polar, diminuindo assim a tensão superficial da água e tornando hidrófila a partícula de cimento. Camadas de moléculas de água dipolares circundam as partículas hidrófilas de cimento e, como resultado, evitam a sua floculação, e um sistema com boa dispersão é obtido.

A aplicação mais importante de aditivos incorporadores de ar é em misturas de concretos leves, dosados para resistir a ciclos de congelamentos e descongelamentos. Um efeito colateral do ar incorporado é a melhoria da trabalhabilidade dos concretos, particularmente naqueles traços que contêm menos cimento e água, agregados de textura rugosa ou agregados leves. A incorporação de 
ar é, por isso, normalmente empregada na produção de concretos-massa e de concretos leves. Pode-se observar que, uma vez que o aditivo incorporador de ar torna as partículas de cimento hidrófobas, um excesso de aditivo pode provocar um retardamento excessivo na hidratação do cimento. Grandes quantidades de ar incorporado são acompanhadas de uma correspondente perda de resistência.

Quantidades de aditivos redutores de água maiores do que o normalmente necessário para um efeito plastificante ou redutor de água podem retardar o tempo de pega, evitando a floculação dos produtos de hidratação. Assim, dependendo da dosagem, muitos tensoativos podem servir simultaneamente como redutores de água e retardadores de pega. Redutores de água comerciais podem conter agentes aceleradores para compensar a tendência retardante, quando ela não é desejada. METHA \& MONTEIRO (1994) ressaltam que, exceto o possível retardamento do tempo de pega, as outras propriedades mecânicas do concreto não são afetadas pela presença de agentes redutores de água. As resistências iniciais podem ser aceleradas pela melhor dispersão das partículas de cimento na água.

Os superplastificantes, também chamados aditivos redutores de água de alta eficiência, por serem capazes de reduzir o teor de água de três a quatro vezes em dado traço de concreto, quando comparados a aditivos redutores de água normais, foram desenvolvidos nos anos 70 e têm grande aceitação na indústria da construção em concreto.

Comparados aos redutores de água normais, quantidades relativamente grandes de superplastificantes de até $1 \%$ em massa de cimento podem ser incorporados às misturas de concreto, sem causar exsudação excessiva nem retardamento do tempo de pega, apesar de a consistência ser da ordem de 200 a $250 \mathrm{~mm}$ de abatimento.

Comparada à redução de água de 5 a 10\%, conseguida com o emprego de plastificantes normais, a redução de água no intervalo de 20 a $25 \%$ pode ser frequentemente conseguida no concreto de referência, sem redução da consistência. $\mathrm{O}$ aumento das propriedades mecânicas é geralmente proporcional à diminuição da relação água-cimento. Frequentemente, por uma velocidade muito maior na hidratação do cimento em um sistema bem disperso, os concretos contendo superplastificante mostram resistências a 1, 3 e 7 dias superiores às dos concretos de 
referência, com a mesma relação água-cimento. Isto tem importância especial na indústria de concreto pré-moldado, em que são requeridas resistências elevadas, para um ciclo mais rápido das fôrmas. Com maiores consumos de cimento e relações água-cimento muito menores do que 0,45, é possível atingir taxas ainda maiores de desenvolvimento da resistência.

\subsubsection{Aditivos minerais}

Os aditivos minerais, ou adições minerais, são comumente adicionados ao concreto em grandes quantidades. Além da redução do custo e melhora da trabalhabilidade do concreto fresco, eles podem ser empregados com sucesso para melhorar a resistência do concreto à fissuração térmica, à expansão álcali-agregado e ao ataque por sulfato. São comumente empregados como aditivos minerais os materiais pozolânicos naturais e subprodutos, tais como a cinza volante e a escória. A ASTM C 618, Standard Specification for Fly Ash and Raw or Calcined Natural Pozzolan for Use as a Mineral Admixture in Portland Cement Concrete, abrange as três classes seguintes de aditivos minerais: Classe $\mathbf{N}$, pozolanas naturais ou calcinadas, tais como terras diatomáceas, cherts e folhelos, tufos, cinzas vulcânicas ou pumicita, e materiais calcinados, como as argilas e os folhelos; Classe F, cinza volante normalmente produzida por queima de carvão antracítico ou betuminoso; Classe C, cinza volante, normalmente produzida por queima de carvão lignítico ou sub-betuminoso (além de pozolânica, esta cinza volante também é cimentante).

Aditivos minerais são silicosos finamente moídos, adicionados ao concreto em quantidades relativamente grandes, geralmente na faixa de 20 a $100 \%$ da massa de cimento Portland. Os benefícios trazidos pelo emprego de aditivos minerais em concretos e argamassas incluem melhora na resistência à fissuração térmica, por causa do calor de hidratação mais baixo, aumento das resistências e da impermeabilidade por refinamentos dos poros e, como resultado da redução da alcalinidade, uma durabilidade maior a ataques químicos, tais como os provenientes de águas sulfatadas e expansão álcali-agregado.

Alguns aditivos minerais são pozolânicos, alguns são cimentantes e outros são tanto cimentantes como pozolânicos. Os aditivos minerais podem ainda ser divididos em materiais naturais e subprodutos. Os materiais naturais são os que foram processados com o único propósito de produzir pozolana; por exemplo: vidros 
vulcânicos, tufos vulcânicos, argilas ou folhelos calcinados e terra diatomácea. Os subprodutos são materiais que não são produtos primários de suas respectivas indústrias produtoras, como, por exemplo, cinza volante, escória de alto-forno, sílica ativa e cinza de casca de arroz. Subprodutos industriais podem ou não requerer um processamento antes do emprego como aditivos minerais.

Dentre esses aditivos minerais mencionados pode-se destacar a sílica ativa, muito utilizada no Brasil quando se desejam concretos ou argamassas com alto desempenho. A sílica ativa, pozolana com alto poder de reação, é também conhecida por outros nomes, como fumo de sílica condensada, sílica volatizada ou simplesmente fumo de sílica. É um subproduto de forno-a-arco e de indução das indústrias de silício metálico e ligas ferro-silício. A redução de quartzo a silício em temperaturas de até $2000^{\circ} \mathrm{C}$ produz vapor de $\mathrm{SiO}$, que oxida e condensa, em zonas de baixa temperatura, as partículas esféricas minúsculas, consistindo em sílica não cristalina. O material removido por filtração dos gases de exaustão em filtros de manga possui um diâmetro médio da ordem de $0,1 \mu \mathrm{m}$ e área específica da ordem de 20 a $25 \mathrm{~m}^{2} / \mathrm{kg}$. Comparada ao cimento Portland comum e às cinzas volantes típicas, a sílica ativa apresenta distribuição granulométrica das partículas duas ordens de grandeza mais finas. É por isso que o material, por um lado, é altamente pozolânico, mas, por outro, cria problemas de manuseio e aumenta apreciavelmente o consumo de água dos concretos e das argamassas, a menos que se acrescente aditivo redutor de água. Os subprodutos da indústria do metal silício contêm 85 a 90\% de sílica nãocristalina; o subproduto da produção de liga ferro-silício com $50 \%$ de silício contém um teor de sílica menor e é menos pozolânico.

NEVILLE (1982) comenta que, de modo geral, a adição de sílica ativa à massa, na proporção de 10 a $15 \%$ do cimento, melhora a coesão e a aderência do concreto projetado, e a reflexão é diminuída. Dessa forma, o concreto pode entrar em serviço com menor idade. É boa a durabilidade de concretos obtidos desse modo. 


\subsection{SOBRE A DOSAGEM DE CONCRETOS E ARGAMASSAS}

A dosagem de um concreto ou de uma argamassa pode ser definida como a busca e a seleção dos componentes desses materiais e suas quantidades relativas, para se obter, do modo mais econômico possível, um material que atenda a certos requisitos mínimos em relação à consistência, resistência e durabilidade. Das condições técnicas a serem levadas em conta durante a dosagem, em relação aos concretos e argamassas endurecidos, são exigidas a resistência e a durabilidade, e, em relação aos materiais no estado fresco, faz-se a exigência de uma boa trabalhabilidade. Em uma dosagem bem feita, a limitação no consumo de cimento em geral está relacionada ao requisito de ordem econômica. Mas se outras exigências de cunho estético forem preponderantes no custo, a aparência da superfície do concreto ou da argamassa pode influir de maneira decisiva sobre a dosagem.

Em dosagens comuns, a procura de misturas mais pobres possíveis é um dos principais objetivos considerados, já que o custo do aglomerante, no caso o cimento, costuma ser alto em relação aos demais componentes do material. Além disso, a economia de cimento pode, a depender do tipo de obra, amenizar problemas, como o desprendimento excessivo de calor de hidratação de cimento, e seguramente diminuir o aparecimento de retração e de fissuração.

\subsubsection{A resistência}

A resistência mecânica do concreto ou da argamassa é condicionada pela relação água-cimento. Considerando-se constantes todos os outros fatores que influem na resistência, como qualidade dos agregados e condições ambientais, a resistência fica na dependência única da relação água-cimento.

Pode-se impor aos concretos ou às argamassas as resistências que se desejarem, pois, sendo fatores quantitativos, podem ser modificadas sob controle.

$\mathrm{O}$ fato de apenas um percentual constante da água de amassamento ser indispensável à hidratação do cimento explica por que a resistência de concretos e argamassas diminui ao se aumentar a relação água-cimento. O excesso de água utilizada na mistura é necessário para produzir condições de manipulação da massa, mas, em contrapartida, é o responsável pela porosidade da pasta de cimento, que, 
manifestando-se em maior ou em menor grau, será o indicador, respectivamente, de mais baixa ou mais alta resistência.

Nos casos de argamassas estruturais, a resistência mecânica não se revela alvo de preocupação, um vez que o consumo de cimento é geralmente alto. Assim é que, na maioria das vezes, as obras em argamassa armada são satisfatórias do ponto de vista da resistência.

\subsubsection{A durabilidade}

As características de durabilidade estão mais intimamente ligadas à qualidade da pasta de cimento. Para controle da durabilidade de concretos e argamassas, a relação água-cimento é um parâmetro fundamental da dosagem.

Nos casos de estruturas de pequena espessura, como as que podem ser obtidas com as tecnologias de concretos pré-moldados ou de argamassa armada, a durabilidade é um aspecto de fundamental importância, já que em tais estruturas o cobrimento das armaduras é muito pequeno em relação a outras peças de concreto armado e deve ser levado em conta na etapa da dosagem dos materiais.

CUNHA (1991) afirma que, devido à camada de cobrimento da armadura em argamassa estrutural ser menor do que no concreto, deve-se aumentar a preocupação com a velocidade de carbonatação da pasta de cimento que, por sua vez, depende da espessura dessa camada e da relação água-cimento. A retração das argamassas por carbonatação pode provocar fissuras nas peças, abrindo caminho para outros agentes destruidores do material e contribuindo ainda mais para diminuir a sua durabilidade.

A durabilidade é também influenciada pelas condições de manipulação e de execução das misturas, bem como da sua colocação e de todos os demais cuidados advindos das operações em obra.

Outro aspecto da durabilidade de argamassas e concretos é o caso das deformações que independem de forças externas, como a retração. Essa deformação faz surgir tensões de tração que podem exceder sua resistência, e então aparecem fissuras que, além de afetarem a própria resistência, influem na durabilidade e na aparência dos materiais.

Ao se executarem argamassas e concretos, deve-se providenciar o mais cedo possível o início da cura, para evitar uma evaporação rápida da água, pois, mesmo 
antes da pega, já ocorre um tipo de retração denominada retração plástica, decorrente da redução de volume do sistema cimento e água, que provoca fissuras na massa recém-executada. A retração plástica depende da umidade, da temperatura, da velocidade do ar e do volume da peça, parâmetros esses que afetam a evaporação da água.

Outro tipo de retração é a retração hidráulica, ou retração por secagem, que é resultante da saída de água após a hidratação dos componentes do cimento, ou seja, depois da pasta endurecida.

A retração de uma argamassa depende de características intrínsecas do material, como, por exemplo, consumo de cimento, relação água-cimento e teor de água de amassamento, bem como de características de seus constituintes, como capacidade de retenção de água em função da finura, da forma e da textura superficial dos grãos. Depende também da geometria das peças executadas, que é levada em conta pela área exposta ao ar por unidade de volume do material moldado. Nas peças de argamassa armada de pequena espessura, a velocidade de secagem é maior, pois existe maior superfície exposta do que em peças comuns de concreto armado.

Segundo CUNHA (1991), não é somente o cuidado com a dosagem que garante a durabilidade e outros requisitos a ela ligados e desejáveis ao material. É necessário ter cuidados especiais na moldagem, no lançamento, na cura etc.

Ainda outro tipo de retração é a retração por carbonatação, resultante da combinação do $\mathrm{CO}_{2}$ da atmosfera com os compostos hidratados do cimento, em especial o $\mathrm{Ca}(\mathrm{OH})_{2}$, e essa reação ocorre ao longo do tempo, indo da superfície para o interior das peças. O tipo de cimento e a relação água-cimento influem na profundidade da carbonatação, que diminui com o aumento da resistência à compressão, que, por sua vez, é um indicador da permeabilidade do concreto.

A baixa permeabilidade é outro requisito importante na durabilidade de argamassas e concretos. A influência do agregado sobre a permeabilidade será forte se o agregado possuir baixa permeabilidade. A busca de misturas adequadas é mais um aspecto referente à redução do volume de vazios entre os agregados, para diminuir a permeabilidade das misturas. 


\subsubsection{A Trabalhabilidade}

A trabalhabilidade de concretos e argamassas é um requisito a ser considerado na dosagem referente ao estado fresco das misturas. O concreto fresco é dito trabalhável quando apresenta consistência e máxima dimensão dos agregados adequadas ao tipo de obra e aos métodos adotados para lançamento, adensamento e acabamento, não apresentando segregação nem exsudação e podendo ser convenientemente compactado. Quando tudo isto é compatibilizado, existe trabalhabilidade. Modificando-se um desses fatores, exige-se a alteração de outros, para que se mantenha a mesma trabalhabilidade.

A consistência é o comportamento físico mais importante da trabalhabilidade, que está relacionada com a mobilidade da massa e com a coesão entre os componentes da mistura. Consistência de uma massa fresca, seja um concreto ou uma argamassa, é a resistência oferecida quando se aplica um esforço sobre ela. $\mathrm{O}$ material mais deformável será, para um mesmo esforço, o menos consistente. O índice de consistência da argamassa pode ser medido através do ensaio da mesa de escorregamento (flow table), constante na NBR 7215 (Ensaio de Cimento Portland). A consistência é representada pela deformação sofrida pelo corpo-de-prova troncônico de material fresco, submetido a um esforço correspondente a 30 golpes ou queda da mesa. O índice de consistência é o valor do diâmetro da base do corpo-deprova após a deformação. Os materiais mais pastosos ou mais fluídos apresentam maiores diâmetros após a deformação.

A consistência não deve ser confundida com a trabalhabilidade. Enquanto a consistência diz respeito apenas ao material, a trabalhabilidade não se relaciona somente com o material, mas também com os fatores relativos à sua aplicação na obra.

A consistência depende de vários fatores, dentre os quais se pode citar: características do cimento e os grãos dos agregados, granulometria da mistura seca, quantidade relativa da água, tipos e quantidades de aditivos, teor de ar incorporado naturalmente ou por meio de aditivos, temperatura-ambiente e tempo decorrido após a mistura. 


\subsection{PROCEDIMENTOS PARA EFETUAR UMA DOSAGEM}

No estudo da dosagem de concretos e de argamassas pretende-se chegar a um traço $1: a:$ p : x, onde "a" é a relação agregado miúdo-cimento, "p" a relação agregado graúdo-cimento e x a relação água-cimento, todos em massa. Pode-se por simplificação considerar o traço global $1: \mathrm{m}: \mathrm{x}$, onde $\mathrm{m}=\mathrm{a}+\mathrm{p}$ e representa a relação agregado-cimento.

Os procedimentos utilizados no país para determinação do traço de concretos ou argamassas são variados, mas em linhas gerais se conservam. Basicamente, uma dosagem depende de três parâmetros:

- Relação água-cimento (x);

- Teor de água-materiais $\operatorname{secos}(\mathrm{A})$;

- Granulometria da mistura (proporção dos materiais) : a/p.

Nos concretos, normalmente é considerado que a resistência e a durabilidade só dependem, em princípio, da qualidade da pasta, ou seja, do tipo de cimento e da relação água-cimento. Então, para determinado tipo de cimento, pode-se fixar o valor máximo do parâmetro "x", independentemente do conhecimento dos demais.

A fixação da proporção dos materiais (ou a escolha da granulometria) pode ser feita sem o conhecimento do valor de m e não depende do valor da relação águacimento. É geralmente nessa etapa do estudo que se caracterizam os diversos métodos de dosagem, pois os critérios utilizados para o proporcionamento dos diversos materiais constituintes são bem diversos. Esses critérios são invariavelmente dependentes das características dos materiais e da trabalhabilidade, vinculados à questão econômica, representada pelo menor consumo de pasta.

O tipo de projeto estrutural e o sistema de trabalho no canteiro de obra permitem definir a consistência que conduz à trabalhabilidade desejada. A consistência, então, fica dependente apenas do valor da relação água-materiais secos e pode ser determinada a partir da experimentação de concretos com traços quaisquer, sem depender do conhecimento prévio do valor de "m", desde que sejam feitos com os mesmos materiais a serem empregados na obra e com a granulometria já anteriormente escolhida. 
O valor de "m" é calculado a partir do conhecimento de "x" e "A" e, em seguida, é desmembrado em suas partes constituintes, segundo a proporção indicada na granulometria ou no critério previamente adotado.

Nos casos de microconcretos e argamassas estruturais, a dosagem pode ser feita por método experimental, podendo-se realizar ensaios de controle para avaliar as características de desempenho do material especificado. Algumas indicações empíricas baseadas em experiências anteriores podem também ser levadas em conta no procedimento de dosagem.

Em relação ao custo de dosagem, HANAI (1981) ressalta que, desejando-se a maior economia possível, deve-se reduzir o consumo de cimento, mas os requisitos de qualidade do material não devem ser colocados em segundo plano.

Segundo LIBÓRIO \& MELO (1997), o estudo de dosagem para as argamassas estruturais, aplicadas, por exemplo, na produção de pré-moldados de pequena espessura, deve levar em conta algumas informações básicas, tais como:

a) Resistência característica da argamassa estrutural à compressão $\left(f_{\mathrm{ck}}\right)$, definida no projeto do elemento a ser pré-moldado (em geral referida à idade de 28 dias);

b) Composição da armadura, que também deve estar definida no projeto estrutural do elemento;

c) Escolha da dimensão máxima do agregado graúdo, limitada a 9,5mm ou a $1 / 4$ da distância entre as faces dos moldes, em função da espessura do elemento (prémoldados com até 40mm de espessura);

d) Definição do elemento estrutural a ser pré-moldado (painel para laje de forro, piso ou vedação vertical etc.);

e) Definição da consistência da argamassa estrutural utilizada (medida em mesa de espalhamento - Flow table), em função do tipo de elemento, do tipo de molde (unilateral, dupla face etc.) e do plano de moldagem;

f) Definição da relação água-cimento $(\mathrm{a} / \mathrm{c})$ e da quantidade de água por metro cúbico, para atender as seguintes condições de durabilidade:

\begin{tabular}{l|l}
$\mathrm{a} / \mathrm{c} \leq 0,45 \mathrm{e} \mathrm{H}_{2} \mathrm{O} \leq 250 \mathrm{~kg} / \mathrm{m}^{3}$ & para peças expostas às intempéries \\
\hline $0,45<\mathrm{a} / \mathrm{c}<0,55$ e $\mathrm{H}_{2} \mathrm{O} \leq 250 \mathrm{~kg} / \mathrm{m}^{3}$ & $\begin{array}{l}\text { para peças protegidas e sem risco de } \\
\text { condensação da umidade }\end{array}$
\end{tabular}


g) Compatibilidade entre quantidade de água por $\mathrm{m}^{3}$, relação a/c (limitada pelos parâmetros de durabilidade) e consistência adequada ao processo de moldagem dos elementos com argamassas estruturais, consistência essa que pode ser obtida com o uso de aditivos redutores de água (plastificantes e superplastificantes). 


\section{RESISTÊNCIA EFETIVA DA ARGAMASSA PROJETADA}

\subsection{MÉTODOS DE ENSAIO}

O controle de qualidade do concreto projetado é realizado através de métodos específicos de ensaio. Não se aplicam, na maioria dos casos, àqueles desenvolvidos para o concreto moldado convencional.

O conhecimento da evolução das resistências mecânicas do concreto projetado, nas primeiras horas após sua projeção, é vital para a segurança do pessoal envolvido na execução. PRUDÊNCIO JR. (1993) observa que, em concretos recémprojetados, por causa da impossibilidade de se extraírem corpos-de-prova até que as resistências atinjam valores da ordem de $5 \mathrm{MPa}$, o monitoramento das resistências nesse período tem que ser realizado por meios indiretos. Citam-se a seguir alguns métodos estudados por vários pesquisadores:

- Penetração de agulha por ação normal;

- Ensaio de arrancamento;

- Cravação de agulhas;

- Esclerômetro.

Vários outros procedimentos têm sido propostos para avaliação da resistência em baixas idades. Na bibliografia também são encontradas referências quanto à utilização de ultra-som, mas não estão disponíveis resultados que avaliem a eficácia deste tipo de teste.

A resistência à compressão em idades maiores que um dia, ou quando superior a $5 \mathrm{MPa}$, é normalmente avaliada a partir de ruptura de corpos-de-prova, obtidos por extração ou serragem de placas-teste ou por ensaio da própria estrutura. Esse procedimento é universalmente aceito, apesar de às vezes ser criticado pelo fato 
de ser caro, ou mesmo pela falta de precisão quando da utilização de placas, devido à representatividade do material (PRUDÊNCIO JR., 1993).

$\mathrm{O}$ citado autor ainda complementa: "a utilização de corpos-de-prova cilíndricos de diferentes diâmetros pode conduzir a resultados distintos devido à influência do processo de extração. Além disso, o uso de fatores de correção para diferentes relações altura/diâmetro ou para conversão de resistência de corpos-deprova cúbicos para cilíndricos tem sido questionado por vários autores."

A obtenção de corpos-de-prova de concreto projetado é feita através da moldagem de placas, conforme a norma NBR 13070 (1994), que, segundo FIGUEIREDO (1997), não pode ser classificada como uma operação simples. A fig.5.1 mostra o sistema de moldagem da placa.

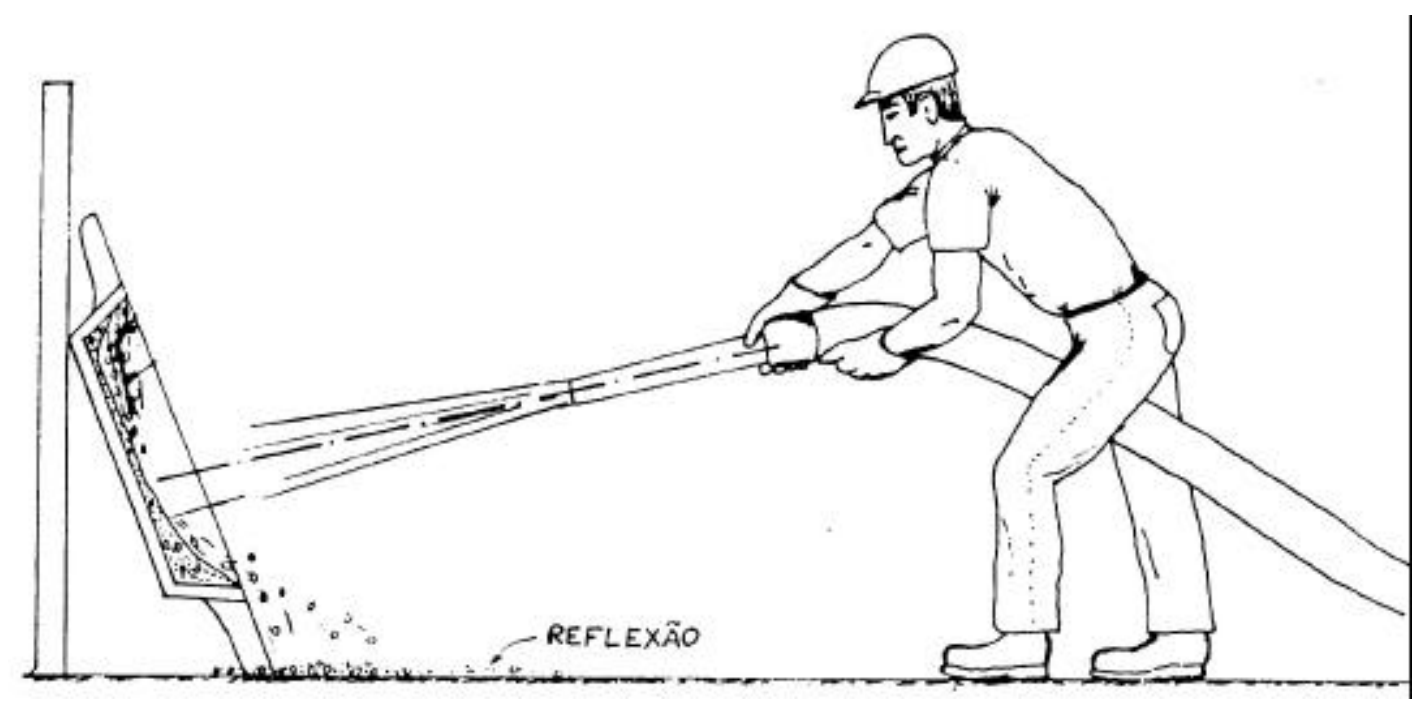

FIGURA 5.1 - MOLDAGEM DA PLACA (FIGUEIREDO, 1997)

De acordo com a NBR 7680 (1983), os corpos-de-prova devem ser extraídos por meio de uma serra-copo diamantada. O espaçamento entre os furos deve ser de no mínimo um diâmetro e, para que seja caracterizado um lote, todos os corpos-deprova devem ser extraídos de pontos da estrutura com a mesma direção de projeção, a qual deve ser previamente especificada em conjunto com a idade de extração.

A preparação dos corpos-de-prova e o ensaio devem seguir as indicações da NBR 7680, tendo-se o cuidado de:

- Serrar os topos dos corpos-de-prova, de modo a torná-los planos e perpendiculares ao eixo de extração; 
- Utilizar sistema de fixação dos corpos-de-prova, dotado de cinta metálica que impeça o deslocamento de seu eixo, na direção perpendicular ao plano da serra circular;

- Logo após serem preparados, os corpos-de-prova devem ser colocados em câmara úmida e nela permanecer até a data do ensaio.

Em geral, os elementos de concreto executados por meio de projeção possuem espessuras em torno de $10 \mathrm{~cm}$, enquanto as peças obtidas com projeção de argamassa ou de microconcretos podem ter espessuras da ordem de $3 \mathrm{~cm}$.

Por esta razão, procurou-se um processo alternativo para determinar a resistência da argamassa projetada, através da extração de pastilhas por serragem de placas com espessura de $3 \mathrm{~cm}$, correlacionando a resistência à compressão axial de corpos-de-prova cilíndricos e a resistência local do material projetado, obtida em ensaios de amostras extraídas de painéis.

\subsection{METODOLOGIA DO PROCESSO ALTERNATIVO}

Inicialmente determinou-se o traço com que iam ser moldados os corpos-deprova para realização do estudo. $\mathrm{O}$ traço foi obtido experimentalmente (conforme descrito no ANEXO A), com base em uma resistência de referência à compressão $\mathrm{f}_{\mathrm{c} 28}=40 \mathrm{MPa}$, adotada em função do emprego destinado aos elementos e da durabilidade requerida pela estrutura. As proporções dos componentes deveriam ser tais que conduzissem a uma argamassa projetável tanto manualmente como através da caneca de projeção.

A proporção cimento/areia obtida foi de $1: 3$, com adição de $2 \%$ de superplastificante (SP) e $10 \%$ de sílica ativa (SA). O fator água-cimento foi de $\mathrm{a} / \mathrm{c}=0,51$. As proporções são tomadas em função do peso de cimento. A utilização da sílica ativa melhorou algumas características da argamassa, tais como coesão, resistência e compacidade. Foram utilizados cimento tipo-ARI e areia média.

Para obter a relação entre as resistências à compressão da argamassa projetada e de corpos-de-prova cilíndricos, foram realizados ensaios de amostras extraídas de corpos-de-prova moldados e de painéis projetados, amostras essas com as mesmas formas e as mesmas dimensões, ora denominadas Pastilhas Moldadas e Pastilhas Projetadas, respectivamente. 
O procedimento consistiu em se moldarem alguns corpos-de-prova de dimensões 10 x $20 \mathrm{~cm}$ e, após um período de cura de sete dias, submetê-los a um processo de serragem, extraindo-se deles pastilhas de dimensões $6 \mathrm{~cm} \times 6 \mathrm{~cm} \times 3 \mathrm{~cm}$, conforme representado na fig.5.2.

De cada corpo-de-prova, em função da posição da qual foram extraídas, foram identificadas três classes: pastilhas de topo, meio e base.

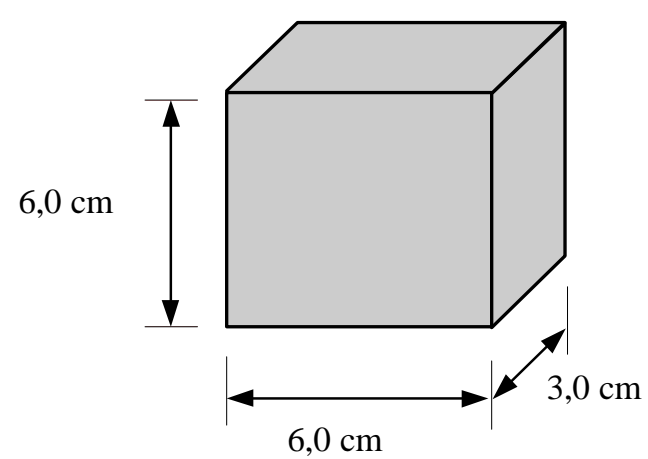

FIGURA 5.2 - ESQUEMA DAS PASTILHAS EXTRAÍDAS DOS CORPOS-DE-PROVA

Depois de extraídas e identificadas, as pastilhas foram ensaiadas à compressão axial, e os resultados foram submetidos a tratamentos estatísticos, a partir dos quais se obteve o fator de forma que relaciona as resistências das pastilhas e dos corpos-de-prova cilíndricos.

\subsection{EXTRAÇÃO DAS PASTILHAS DOS CORPOS-DE-PROVA}

Para extração das pastilhas, três dias após a moldagem, os corpos-de-prova foram submetidos a um procedimento de serragem, feito por meio de uma serra circular com mesa deslizante.

O primeiro passo do processo de serragem era a fixação dos elementos de apoio do corpo-de-prova. Os elementos consistiam em blocos paralelepipédicos de madeira com superfícies perfeitamente planas e paralelas. Esses elementos eram fixados na mesa deslizante da serra circular por meio de garras metálicas (fig.5.3). O processo de fixação dos apoios repetiu-se em todos os passos subseqüentes. 


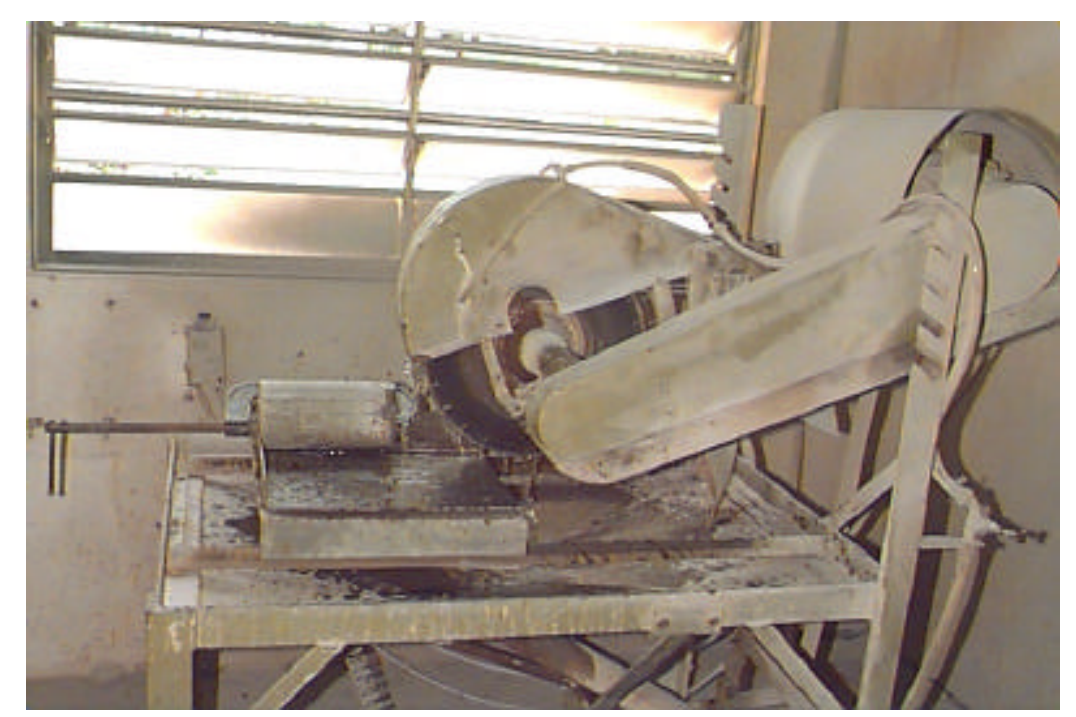

FIGURA 5.3 - SERRA CIRCULAR COM MESA DESLIZANTE

Posicionando-se o corpo-de-prova na mesa deslizante, escorado nos elementos de apoio, conforme ilustra a fig.5.3, executava-se o primeiro corte longitudinal, com o objetivo de constituir uma base plana para facilitar os cortes subseqüentes, visto que os corpos-de-prova têm perímetro circular, o que dificulta o processo de serragem.

Apoiando-se o corpo-de-prova sobre a face do primeiro corte, executavam-se dois cortes laterais, espaçados de $6 \mathrm{~cm}$ (dimensão lateral das pastilhas). A fig.5.4 ilustra o primeiro desses dois cortes.

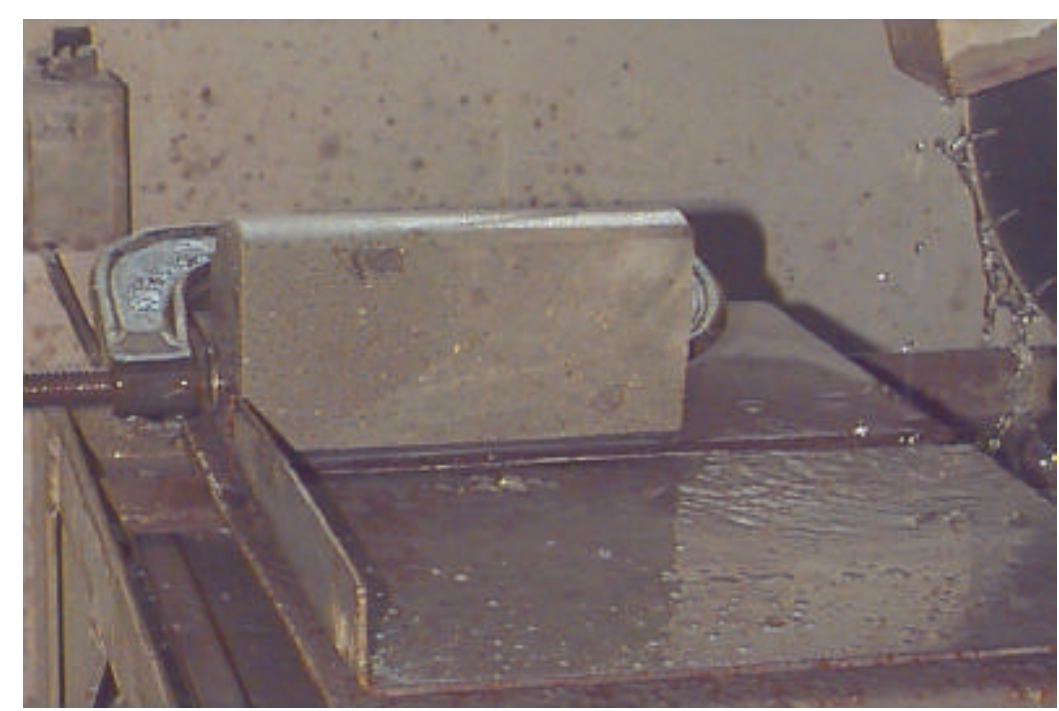

FIGURA 5.4 - DETALHE DO CORPO-DE-PROVA DURANTE O PROCESSO DE SERRAGEM 
Colocando-se o corpo-de-prova sobre uma das superfícies cortadas, procediase à retificação do primeiro corte longitudinal, a fim de eliminar as irregularidades. Em seguida executava-se o último corte longitudinal, espaçado de $3 \mathrm{~cm}$ em relação ao seu lado oposto, o primeiro corte retificado. Com isto obtinha-se um elemento de seção de $3 \mathrm{~cm}$ x $6 \mathrm{~cm}$ e comprimento de $20 \mathrm{~cm}$ (altura do próprio corpo-de-prova). Esse elemento está apresentado na figura 5.5, já pronto para o passo seguinte.

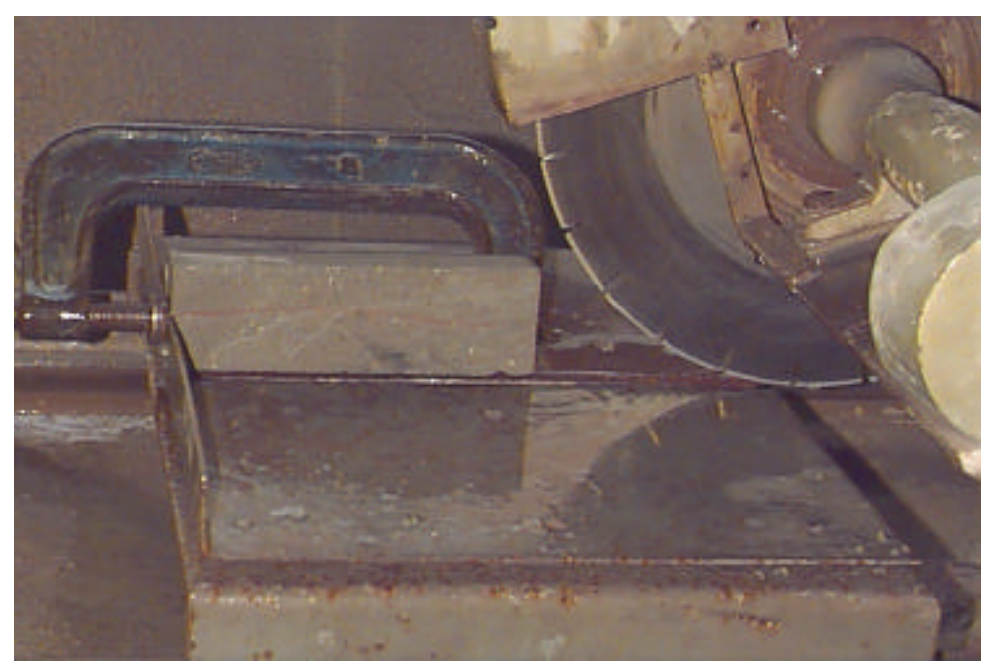

FIGURA 5.5 - DETALHE DO ELEMENTO DE DIMENSÕES 3CM X 6CM X 20CM

O último passo do processo de corte consistia em separar o elemento obtido em pastilhas de topo, meio e base, através de cortes transversais espaçados de $6 \mathrm{~cm}$ (altura das pastilhas) e identificá-los imediatamente após sua separação. O resultado do processo de extração das pastilhas é visto na fig.5.6.

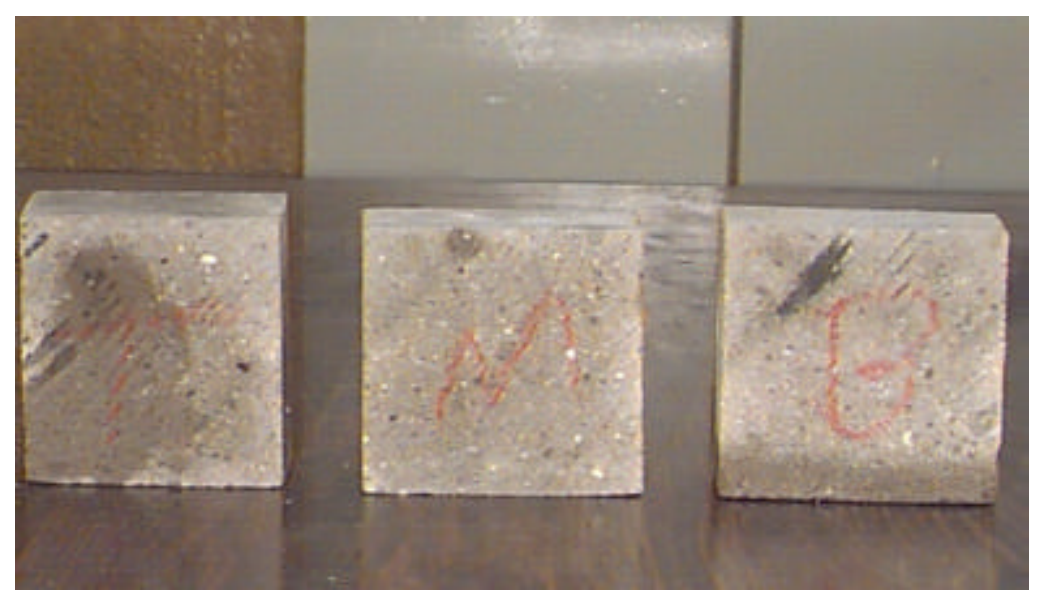

FIGURA 5.6 -DA ESQUERDA PARA A DIREITA: PASTILHAS DE TOPO, MEIO E BASE 
O processo de extração das pastilhas foi modificado várias vezes até atingir o procedimento ora descrito, o qual proporcionou lotes com melhor qualidade de pastilhas, no que se refere à uniformidade de dimensões e paralelismo das faces. Inclui-se nessas modificações, além do processo de serragem, o desenvolvimento dos aparelhos de fixação de apoio, usados durante os cortes.

Deve-se destacar que essas pastilhas foram ensaiadas na mesma posição em que o corpo-de-prova estaria, quer dizer, sua posição espacial foi mantida, como se estivesse no corpo-de-prova.

\subsection{EXECUÇÃO DAS PLACAS DE ARGAMASSA PROJETADA}

Utilizando-se o traço padrão, procedeu-se à projeção da argamassa em três painéis de EPS (poliestireno expandido), para que pudessem ser extraídas e ensaiadas as pastilhas projetadas. O painel de EPS foi escolhido como base para a projeção, por se tratar de um material bastante utilizado como núcleo de painel tipo sanduíche, simulando uma situação real de utilização de argamassa projetada.

Para a projeção, os painéis de EPS foram adquiridos nas dimensões $100 \mathrm{~cm} \mathrm{x}$ $20 \mathrm{~cm}$ x $5 \mathrm{~cm}$. Desenvolveu-se um sistema de fôrmas para os painéis, com a finalidade de assegurar a espessura do material de projeção $(3 \mathrm{~cm})$ e amenizar possíveis desperdícios de material junto às bordas (fig.5.7).

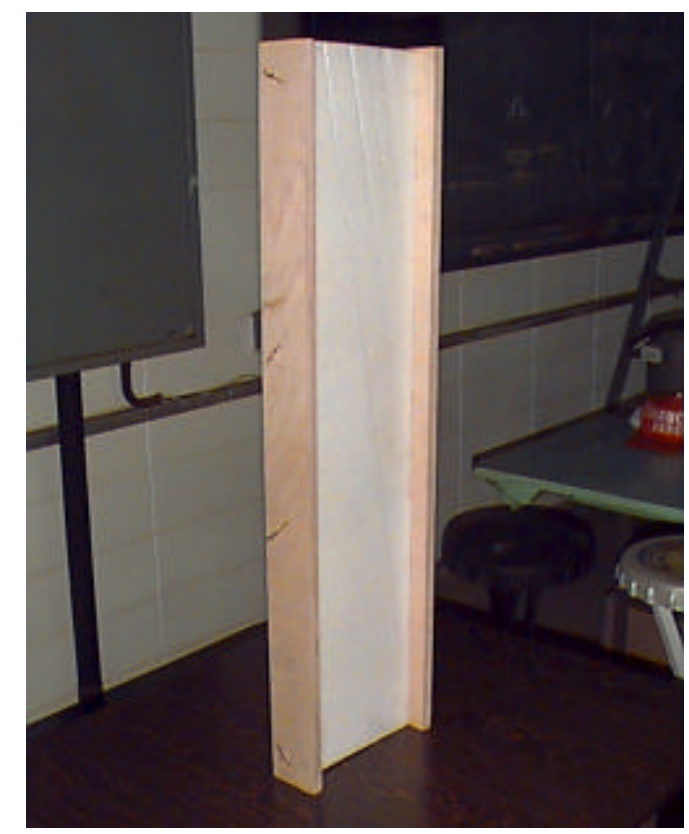

FIGURA 5.7 - FÔRMAS PARA OS PAINÉIS DE EPS 
Para a projeção, os painéis foram posicionados contra um anteparo rígido, com o maior de seus lados na direção vertical, conforme indicado na fig.5.8.

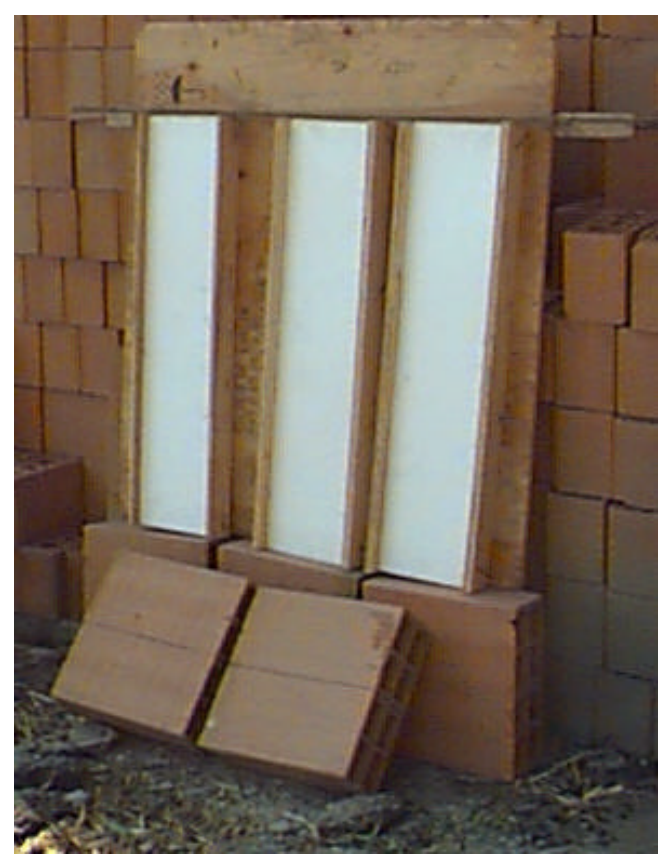

FIGURA 5.8 - POSICIONAMENTO DOS PAINÉIS DE PROJEÇÃO

Na execução das placas foi utilizada uma caneca de projeção acoplada a um compressor de ar, calibrado com pressão de 100 psi $\left(\operatorname{lbs} / \mathrm{in}^{2}\right)$. A projeção foi executada de baixo para cima, mantendo-se a caneca de projeção a uma distância de aproximadamente $30 \mathrm{~cm}$ (fig.5.9).

O processo de projeção foi executado em duas etapas. Na primeira, depois de preparada a argamassa, procedeu-se à projeção de uma camada de aproximadamente $0,5 \mathrm{~cm}$ de espessura, com a finalidade de formar uma superfície aderida ao painel de EPS e resistente o bastante para suportar a camada seguinte (fig.5.9). 


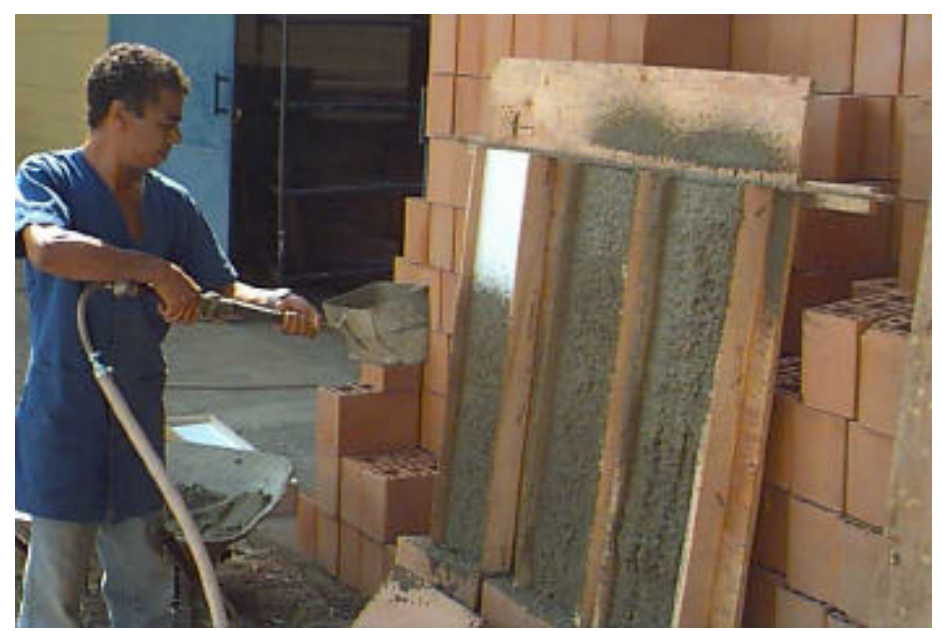

FIGURA $5.9-1^{\mathrm{a}}$ ETAPA DA PROJEÇÃO DOS PAINÉIS

Na segunda etapa de projeção, que foi realizada seis horas após a execução da primeira camada, completaram-se os $3 \mathrm{~cm}$ de espessura. Após o fim da projeção, desempenou-se a superfície dos painéis com o uso de régua de madeira e desempenadeira de alumínio, conforme o processo utilizado no desempeno de reboco de paredes de edificações (fig.5.10).

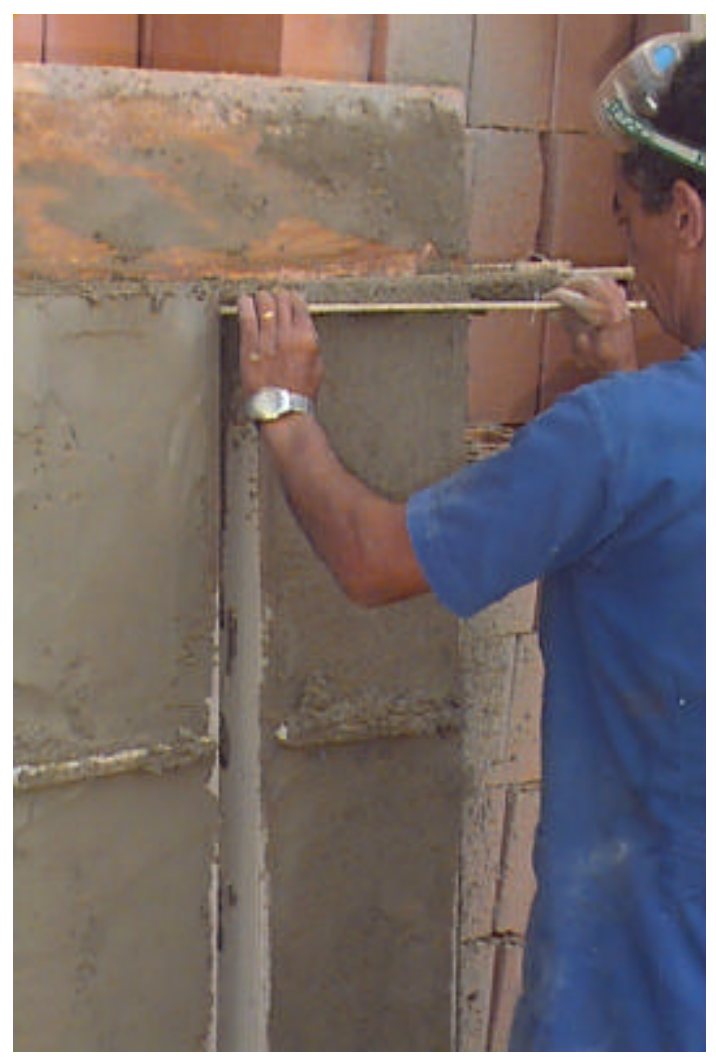

FIGURA 5.10 - RETIFICAÇÃO DA ESPESSURA DOS PAINÉIS 
Com a argamassa utilizada em ambas as projeções, foram moldados três corpos-de-prova cilíndricos de dimensões $10 \mathrm{~cm}$ x $20 \mathrm{~cm}$.

Nas primeiras 24 horas depois da projeção, os painéis foram envoltos com plástico para que mantivessem sua umidade. Nos dias subseqüentes, os painéis foram colocados na posição horizontal e cobertos com espuma úmida, para dar continuidade à cura da argamassa.

\subsection{SERRAGEM DAS PASTILHAS DAS PLACAS DE ARGAMASSA PROJETADA}

O processo de extração das pastilhas projetadas seguiu o mesmo padrão utilizado na extração das pastilhas moldadas, apenas adaptado à nova situação, ou seja, extração das pastilhas a partir de uma placa em vez de um cilindro, fato esse que simplificou a operação.

Após sua extração, as pastilhas projetadas foram submetidas a ensaios de compressão axial, e os resultados foram submetidos a tratamentos estatísticos. Devese destacar que essas pastilhas foram ensaiadas na direção perpendicular à projeção.

\subsection{RESULTADOS OBTIDOS}

Serão apresentados os resultados relativos às pastilhas moldadas e às projetadas.

\subsubsection{Pastilhas moldadas}

Foram utilizadas argamassas com as proporções dos materiais determinadas anteriormente, modificando-se apenas a relação a/c, conforme apresentado a seguir:

- $\operatorname{Traço~A~-~1:3~+~SP~(2\% )~+~MS~(10\% ),~com~a/c~=~0,508;~}$

- Traço B - 1:3 + SP (2\%) + MS (10\%), com a/c = 0,597;

- Traço C - 1:3 + SP (2\%) + MS (10\%), com a/c =0,469.

Os Índices de Consistência obtidos para essas pastilhas foram:

- Traço A - 190 mm;

- Traço B - 200 mm;

- Traço C - $165 \mathrm{~mm}$. 
Para cada um desses traços foi extraída uma série de pastilhas de topo, meio e fundo, que foram rompidas por compressão axial, gerando os valores apresentados na tab.5.1.

Com relação aos traços $\mathrm{A}$ e $\mathrm{B}$, os dados são referentes a quatro conjuntos de pastilhas. Para o traço C romperam-se sete conjuntos. A última coluna da tabela 5.1 refere-se à ruptura de corpos-de-prova de $10 \mathrm{~cm}$ x $20 \mathrm{~cm}$, tidos como valores de referência.

TABELA 5.1 - Resistência à compressão das pastilhas extraídas dos corpos-deprova cilíndricos

\begin{tabular}{|c|c|c|c|c|}
\hline \multicolumn{5}{|c|}{ Traço A } \\
\hline \multirow[t]{2}{*}{ Pastilha } & \multicolumn{3}{|c|}{$\begin{array}{l}\text { Tensão de Ruptura } \\
\text { (MPa) }\end{array}$} & \multirow{2}{*}{$\begin{array}{l}\text { Resistência dos } \\
\text { Corpos-de-Prova } \\
\text { (MPa) }\end{array}$} \\
\hline & Base & Meio & Topo & \\
\hline 01 & 23,0 & 23,3 & 10,1 & 31,6 \\
\hline 02 & 22,8 & 19,4 & 18,6 & 32,1 \\
\hline 03 & 15,8 & 16,2 & 22,9 & 32,6 \\
\hline 04 & 24,3 & 18,0 & 14,9 & Média $=32,1 \mathrm{MPa}$ \\
\hline \multicolumn{5}{|c|}{ Traço B } \\
\hline \multirow{2}{*}{ Pastilha } & \multicolumn{3}{|c|}{$\begin{array}{c}\text { Tensão de Ruptura } \\
\text { (MPa) }\end{array}$} & \multirow{2}{*}{$\begin{array}{c}\text { Resistência dos } \\
\text { Corpos-de-Prova } \\
\text { (MPa) }\end{array}$} \\
\hline & Base & Meio & Topo & \\
\hline 01 & 23,0 & 20,6 & 26,7 & 37,8 \\
\hline 02 & 21,8 & 27,1 & 26,1 & 37,3 \\
\hline 03 & 28,9 & 22,5 & 25,7 & 37,8 \\
\hline 04 & 31,1 & 17,8 & 20,1 & Média $=37,6 \mathrm{MPa}$ \\
\hline \multicolumn{5}{|c|}{ Traço C } \\
\hline \multirow[t]{2}{*}{ Pastilha } & \multicolumn{3}{|c|}{$\begin{array}{c}\text { Tensão de Ruptura } \\
\text { (MPa) }\end{array}$} & \multirow{2}{*}{$\begin{array}{c}\text { Resistência dos } \\
\text { Corpos-de-Prova } \\
\text { (MPa) }\end{array}$} \\
\hline & Base & Meio & Topo & \\
\hline 01 & 25,1 & 25,1 & 39,7 & 55,8 \\
\hline 02 & 44,0 & 32,4 & 36,7 & 55,3 \\
\hline 03 & 36,4 & 19,9 & 35,4 & 55,5 \\
\hline 04 & 34,3 & 23,8 & 33,6 & 55,1 \\
\hline 05 & 31,8 & 32,5 & 33,9 & Média $=55,4 \mathrm{MPa}$ \\
\hline 06 & 36,0 & 32,3 & 35,0 & \\
\hline 07 & 36,4 & 24,9 & 34,2 & \\
\hline
\end{tabular}




\subsubsection{Pastilhas projetadas}

Para a extração dessas pastilhas foram construídas três placas, utilizando-se o traço determinado, com relação a/c de 0,50, obtendo-se um Índice de Consistência de $190 \mathrm{~mm}$.

Para cada um dos painéis projetados foi extraída uma série de pastilhas (15 no total), que foram rompidas por compressão axial, gerando os valores apresentados na tabela 5.2.

Todas as placas foram feitas de uma única vez, utilizando a mesma argamassa. Na tabela 5.3 estão os valores das resistências dos corpos-de-prova cilíndricos de $10 \mathrm{~cm}$ x $20 \mathrm{~cm}$, moldados para cada etapa da projeção, tidos como valores de referência.

TABELA 5.2 - Resistência à compressão das pastilhas extraídas das placas

\begin{tabular}{|c|c|c|c|c|c|}
\hline \multicolumn{2}{|c|}{ Painel 1 } & \multicolumn{2}{c|}{ Painel 2 } & \multicolumn{2}{c|}{ Painel 3 } \\
\hline Pastilha & $\begin{array}{c}\text { Tensão de } \\
\text { Ruptura } \\
\text { (MPa) }\end{array}$ & Pastilha & $\begin{array}{c}\text { Tensão de } \\
\text { Ruptura } \\
\text { (MPa) }\end{array}$ & Pastilha & $\begin{array}{c}\text { Tensão de } \\
\text { Ruptura } \\
\text { (MPa) }\end{array}$ \\
\hline 1 & 30,8 & 1 & 28,5 & 1 & 24,2 \\
\hline 2 & 38,4 & 2 & 35,2 & 2 & 27,4 \\
\hline 3 & 32,2 & 3 & 31,9 & 3 & 24,5 \\
\hline 4 & 34,3 & 4 & 27,8 & 4 & 29,6 \\
\hline 5 & 41,0 & 5 & 25,9 & 5 & 33,3 \\
\hline 6 & 29,7 & 6 & 28,2 & 6 & 25,1 \\
\hline 7 & 30,6 & 7 & 26,9 & 7 & 26,1 \\
\hline 8 & 34,2 & 8 & 33,9 & 8 & 30,9 \\
\hline 9 & 28,3 & 9 & 39,8 & 9 & 24,8 \\
\hline 10 & 27,3 & 10 & 24,2 & 10 & 25,1 \\
\hline 11 & 34,4 & 11 & 23,0 & 11 & 28,9 \\
\hline 12 & 28,3 & 12 & 26,0 & 12 & 25,6 \\
\hline 13 & 28,5 & 13 & 27,8 & 13 & 28,1 \\
\hline 14 & 30,6 & 14 & 26,0 & 14 & 26,0 \\
\hline 15 & 27,3 & 15 & 28,9 & 15 & 31,2 \\
\hline
\end{tabular}

TABELA 5.3 - Resistência à compressão dos corpos-de-prova cilíndricos

\begin{tabular}{|c|c|c|c|c|c|}
\hline Projeção & \multicolumn{2}{|c|}{ Resistência dos Corpos-de-Prova (MPa) } & \multicolumn{2}{c|}{ Média (MPa) } \\
\hline $1^{\text {a }}$ etapa & 52,9 & 51,8 & 55,1 & 53,3 & \multirow{5}{56,2}{} \\
\hline $2^{\text {a }}$ etapa & 56,4 & 56,9 & 64,0 & 59,1 & \\
\hline
\end{tabular}


Durante o ensaio de dois corpos-de-prova cilíndricos, foi determinada a curva tensão x deformação e respectivo módulo de elasticidade, calculados a partir da deformação média dos dois elementos analisados. O módulo de elasticidade encontrado foi de $30.066 \mathrm{MPa}$.

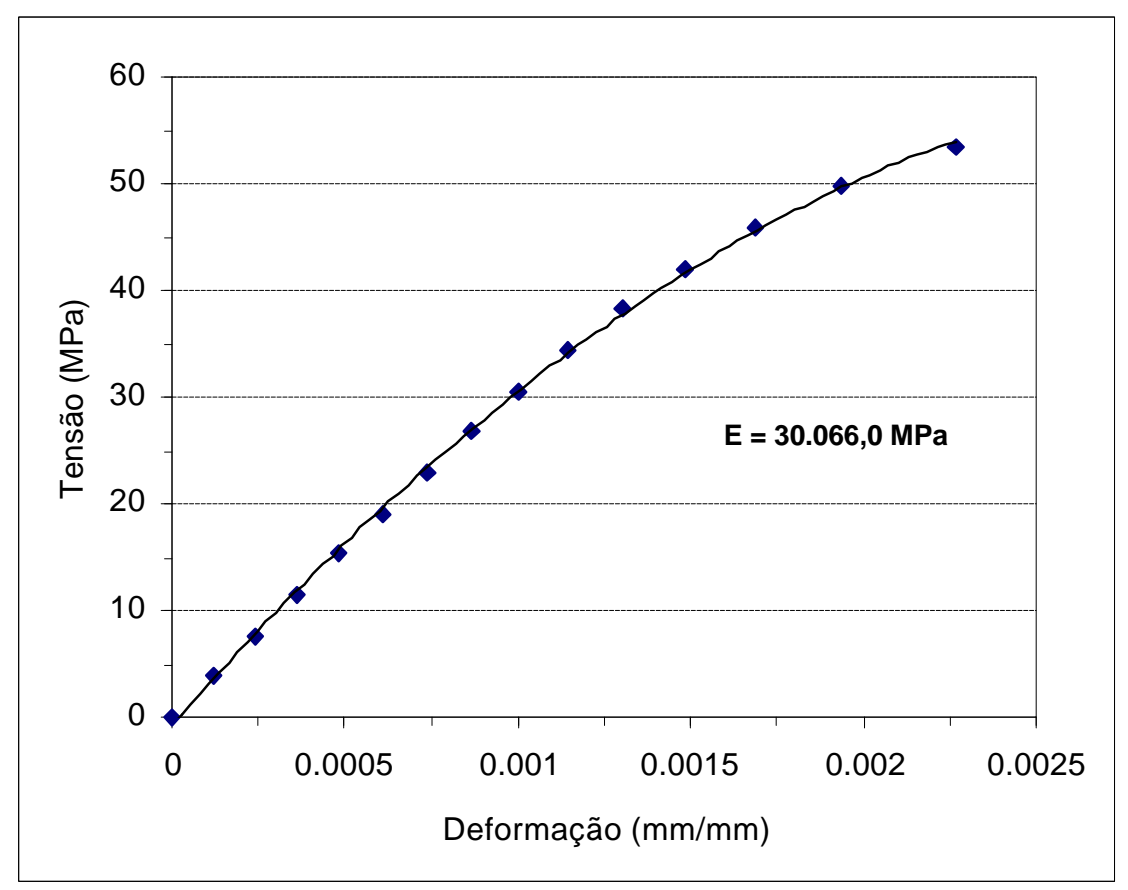

FIGURA 5.11 - CURVA TENSÃO X DEFORMAÇÃO

Um fato interessante detectado foi o modo de ruptura das pastilhas projetadas, quando submetidas à compressão axial. Notou-se que a maioria delas se rompia através de separação ocorrida exatamente na superfície de emenda das projeções, localizada a aproximadamente $0,5 \mathrm{~cm}$ da camada de EPS. Acredita-se que isto tenha ocorrido por causa da grande quantidade de vazios nessa região, o que foi observado durante a extração das pastilhas.

\subsection{CRITÉRIOS DE TRATAMENTO DOS RESULTADOS}

Os dados das tabelas 5.1 e 5.2 sofreram tratamentos estatísticos, que permitiram eliminar valores não representativos das amostras.

Um dos tratamentos utilizados foi o "Critério de Chauvenet". Segundo TAKEYA (1988), esse critério pode ser empregado para descartar resultados suspeitos. O Critério de Chauvenet tem o seguinte enunciado: se em uma série de $n$ 
medidas, a probabilidade de ocorrência de um desvio de valor x é menor que $1 /(2 n)$, então à medida que apresentar tal desvio deverá ser rejeitada". Na análise dos dados foram rejeitadas as medidas superiores ou inferiores ao valor do desvio padrão da amostra, somado a 5\%. Optou-se por trabalhar com esse valor, visto que, se o critério de desclassificação de amostras fosse rigidamente seguido, um número muito grande de amostras seria rejeitado, podendo descaracterizar o conjunto.

Esse critério tem por objetivo eliminar valores não-representativos de amostras pequenas (menores que 50 elementos). Além disso, tem a vantagem de se poder trabalhar conjuntamente dados com valores numericamente diferentes, uma vez que todo o cálculo é baseado na relação entre valores pontuais e a média daquela amostra, reduzindo todos os dados às variações percentuais em torno da respectiva média.

Os dados foram submetidos também a uma segunda análise, na qual foram rejeitados os valores evidentemente não-representativos. Tratando-se de valores excessivamente baixos, as dispersões foram atribuídas a possíveis falhas na extração das pastilhas, traduzindo-se em imperfeições das faces, que deveriam ser planas e paralelas. Foram eliminados também, como não poderia deixar de acontecer, valores de tensão de ruptura excessivamente elevados. A esse critério denominou-se "Desclassificação das Pastilhas Defeituosas ou Não-Representativas".

Após a aplicação dos processos estatísticos às amostras, procedeu-se ao cálculo do fator de forma, que é a relação entre a resistência das pastilhas moldadas e a dos corpos-de-prova cilíndricos das quais elas foram extraídas. Com esse valor foi possível estimar qual a porcentagem de perda de resistência que pode ser atribuída à forma de adensamento da argamassa projetada.

\subsection{APLICAÇÃO DO CRITÉRIO DE CHAUVENET}

Apresentam-se as análises dos resultados dos ensaios das pastilhas, com base no Critério de Chauvenet.

\subsubsection{Pastilhas moldadas}

Como já foi visto, as pastilhas moldadas foram divididas em amostras A, B e $\mathrm{C}$, que diferem apenas do traço, o que traduz valores substancialmente diferentes 
para a tensão de ruptura. As amostras A e B possuem 12 elementos cada, e a amostra C possui 21 elementos, totalizando 45 pastilhas.

Apresenta-se na tab.5.4 o resumo da análise estatística realizada com os dados da tab.5.1. Os detalhes dessa análise estão indicados no ANEXO B.

As resistências de referência indicadas na tab.5.4 correspondem às dos corpos-de-prova cilíndricos relativos a cada amostra. A última coluna fornece a relação entre a resistência média das pastilhas (coluna 2) e a resistência de referência (coluna 5).

TABELA 5.4 - Resumo da análise da resistência das pastilhas extraídas de corposde-prova cilíndricos, através do critério de Chauvenet

\begin{tabular}{|c|c|c|c|c|c|}
\hline Amostra & $\begin{array}{c}\text { Resistência Média das } \\
\text { pastilhas em MPa }\end{array}$ & $\begin{array}{c}\text { Desvio } \\
\text { Padrão }\end{array}$ & $\begin{array}{c}\text { Coef. de } \\
\text { variação }\end{array}$ & $\begin{array}{c}\text { Resistência de } \\
\text { referência em MPa }\end{array}$ & $\begin{array}{c}\text { Fator de } \\
\text { forma }\end{array}$ \\
\hline $\mathrm{A}$ & 19,7 & 3,404 & 0,17 & 32,1 & 0,614 \\
\hline $\mathrm{B}$ & 23,9 & 3,621 & 0,15 & 37,6 & 0,636 \\
\hline $\mathrm{C}$ & 34,7 & 2,132 & 0,06 & 55,4 & 0,626 \\
\hline $\begin{array}{l}\text { Valores médios } \\
\text { das 3 amostras }\end{array}$ & - & $\mathbf{3 , 0 5 2}$ & $\mathbf{0 , 1 3}$ & - & $\mathbf{0 , 6 2 5}$ \\
\hline
\end{tabular}

Pode-se observar na tabela 5.4, em função dos valores médios das três amostras, que uma pastilha de argamassa de $3 \mathrm{~cm} \times 3 \mathrm{~cm} \times 6 \mathrm{~cm}$, extraída de um corpo-de-prova cilíndrico de $10 \mathrm{~cm}$ x $20 \mathrm{~cm}$, ensaiada na direção de maior dimensão, possui uma resistência à compressão 37,5 \% menor que a resistência do corpo-deprova cilíndrico da qual ela foi extraída.

\subsubsection{Pastilhas projetadas}

As pastilhas extraídas das placas projetadas constituem um único conjunto, pois todos os painéis foram executados com o mesmo traço e o mesmo fator a/c. Contudo, foram divididos em painéis 1,2 e 3, com 15 pastilhas cada um, totalizando 45 elementos.

A tab.5.5 apresenta o resumo da análise realizada com os dados contidos na tab.5.2. Os detalhes estão indicados no ANEXO B.

$\mathrm{Na}$ segunda coluna da tab.5.5 estão os valores médios da resistência à compressão das pastilhas projetadas que não foram descartadas através do tratamento estatístico. A terceira e quarta colunas apresentam, respectivamente, o desvio padrão e o coeficiente de variação dos mesmos valores utilizados na obtenção da coluna 2 . 
Finalmente, a última coluna fornece a resistência média de referência da argamassa utilizada na execução dos painéis, obtida a partir de ensaios de compressão de corpos-de-prova cilíndricos de $10 \mathrm{~cm}$ x $20 \mathrm{~cm}$.

TABELA 5.5 - Resumo da análise de resistência das pastilhas projetadas, através do critério de Chauvenet

\begin{tabular}{|c|c|c|c|c|}
\hline Painel & $\begin{array}{c}\text { Resistência Média das } \\
\text { pastilhas em MPa }\end{array}$ & $\begin{array}{c}\text { Desvio } \\
\text { Padrão }\end{array}$ & $\begin{array}{c}\text { Coef. De } \\
\text { variação }\end{array}$ & $\begin{array}{c}\text { Resistência de referência } \\
\text { em MPa }\end{array}$ \\
\hline 01 & 30,5 & 2,600 & 0,09 & 56,2 \\
\hline 02 & 27,1 & 1,072 & 0,04 & 56,2 \\
\hline 03 & 26,0 & 1,674 & 0,06 & 56,2 \\
\hline $\begin{array}{l}\text { Valores médios } \\
\text { dos 3 painéis }\end{array}$ & $\mathbf{2 7 , 9}$ & $\mathbf{1 , 7 8 2}$ & $\mathbf{0 , 0 6}$ & $\mathbf{5 6 , 2}$ \\
\hline
\end{tabular}

Verifica-se, observando a tab.5.5, que a média das resistências das pastilhas projetadas - coluna 2 - é 50,36\% menor que a resistência média de referência coluna 5 -, relativa a corpos-de-prova cilíndricos moldados com a mesma argamassa utilizada na projeção.

Através do mesmo critério de análise estatística, verificou-se no item anterior que, para as pastilhas moldadas, a resistência média é 37,5\% menor que a resistência desses mesmos corpos-de-prova cilíndricos.

Omitindo-se a questão do modo de execução dos painéis (por projeção da argamassa), teoricamente as diferenças entre as resistências médias das pastilhas e a resistências médias dos corpos-de-prova, obtidas nas tabelas 5.4 e 5.5, deveriam ser iguais. Contudo, as pastilhas projetadas não possuem o mesmo grau de adensamento que as pastilhas moldadas, as quais são extraídas dos corpos-de-prova cilíndricos, que são adensados por meio de processos mecânicos mais eficientes. Isto explica a diferença de 12,86 entre as porcentagens encontradas nas tabelas 5.5 e 5.4.

Portanto, as pastilhas moldadas possuem $62,5 \%$ da resistência dos corpos-deprova cilíndricos, e as pastilhas projetadas possuem 49,6\% dessa resistência de referência.

\subsection{CRITÉRIO DE DESCLASSIFICAÇÃO DAS PASTILHAS}

São apresentadas as análises dos resultados dos ensaios das pastilhas, com base no critério de desclassificação das pastilhas defeituosas ou não-representativas. 


\subsubsection{Pastilhas moldadas}

O ANEXO B apresenta com detalhes o procedimento empregado no tratamento estatístico dos dados da tab.5.1, utilizando o critério da desclassificação das pastilhas defeituosas.

A tabela 5.6 apresenta o resumo da análise realizada da mesma maneira como foi feito no item 5.8.1.

TABELA 5.6 - Resumo da análise da resistência das pastilhas moldadas, através do critério da desclassificação das pastilhas

\begin{tabular}{|c|c|c|c|c|c|}
\hline Amostra & $\begin{array}{c}\text { Resistência Média das } \\
\text { pastilhas em MPa }\end{array}$ & $\begin{array}{c}\text { Desvio } \\
\text { Padrão }\end{array}$ & $\begin{array}{c}\text { Coef. de } \\
\text { variação }\end{array}$ & $\begin{array}{c}\text { Resistência de } \\
\text { referência em MPa }\end{array}$ & $\begin{array}{c}\text { Fator de } \\
\text { forma }\end{array}$ \\
\hline $\mathrm{A}$ & 20,94 & 2,902 & 0,14 & 32,1 & 0,652 \\
\hline $\mathrm{B}$ & 24,9 & 3,537 & 0,14 & 37,6 & 0,662 \\
\hline $\mathrm{C}$ & 34,4 & 1,685 & 0,05 & 55,4 & 0,620 \\
\hline $\begin{array}{l}\text { Valores médios } \\
\text { das 3 amostras }\end{array}$ & - & $\mathbf{2 , 7 0 8}$ & $\mathbf{0 , 1 1}$ & - & $\mathbf{0 , 6 4 5}$ \\
\hline
\end{tabular}

O valor médio do fator de forma encontrado através desse critério - tabela 5.6, coluna 6 - é muito próximo do valor indicado na tab.5.1. Essa análise alternativa serviu principalmente para aferir os resultados referentes ao critério de Chauvenet.

\subsubsection{Pastilhas projetadas}

O procedimento detalhado da análise dos dados da tab.5.2, através do critério da desclassificação das pastilhas defeituosas, é mostrado no ANEXO B.

A tabela 5.7 apresenta o resumo da análise realizada da mesma maneira como foi feito no item 5.8.2.

TABELA 5.7 - Resumo da análise da resistência das pastilhas extraídas das placas, através do critério da desclassificação das pastilhas

\begin{tabular}{|c|c|c|c|c|}
\hline Painel & $\begin{array}{c}\text { Resistência Média das } \\
\text { pastilhas em MPa }\end{array}$ & $\begin{array}{c}\text { Desvio } \\
\text { Padrão }\end{array}$ & $\begin{array}{c}\text { Coef. De } \\
\text { variação }\end{array}$ & $\begin{array}{c}\text { Resistência de referência } \\
\text { em MPa }\end{array}$ \\
\hline 01 & 31,1 & 2,386 & 0,08 & 56,2 \\
\hline 02 & 29,3 & 4,068 & 0,14 & 56,2 \\
\hline 03 & 28,9 & 4,134 & 0,14 & 56,2 \\
\hline $\begin{array}{l}\text { Valores médios } \\
\text { dos 3painéis }\end{array}$ & $\mathbf{2 9 , 8}$ & $\mathbf{3 , 5 3 0}$ & $\mathbf{0 , 1 2}$ & $\mathbf{5 6 , 2}$ \\
\hline
\end{tabular}

Através desse critério de avaliação, a resistência média das pastilhas - tabela 5.7, coluna 2 - é de 29,8 MPa, ou seja, 6,8\% maior que o valor obtido na tabela 5.5, que é de 27,9 MPa. 
Pode-se ainda observar que a média das resistências das pastilhas projetadas coluna 2 - é 47,0 \% menor que a resistência média de referência - coluna 5 (resistência à compressão de corpos-de-prova cilíndricos moldados com a mesma argamassa da projeção). Comparando este mesmo valor com o obtido da tabela 5.5, verifica-se que o da tabela 5.7 é um pouco maior, com uma diferença de apenas $3,38 \%$.

Da mesma maneira verificada no item 5.9.1, essa análise através do critério de desclassificação das pastilhas defeituosas serviu principalmente para aferir os resultados da análise referentes ao critério de Chauvenet.

\subsection{CONCLUSÕES PARCIAIS}

De acordo com o "Critério de Chauvenet", o fator de forma é de 0,625, ou seja, se uma pastilha composta pelo traço apresentado nesse trabalho e com área da seção transversal de $3 \mathrm{~cm}$ x $6 \mathrm{~cm}$ e altura de $6 \mathrm{~cm}$ for ensaiada à compressão axial, o valor da resistência alcançada será de 62,5\% do valor referente a um corpo-de-prova composto do mesmo traço, nas dimensões $10 \mathrm{~cm}$ x $20 \mathrm{~cm}$. O desvio padrão obtido foi de 3,052 e o coeficiente de variação, de $13 \%$.

O fator de forma, segundo o critério "Desclassificação das Pastilhas Defeituosas ou Não-Representativas”, é de 0,645, ou seja, para as mesmas condições apresentadas no parágrafo anterior, o valor da resistência de uma pastilha será de $64,5 \%$ do valor relativo a um corpo-de-prova cilíndrico de $10 \mathrm{~cm}$ x $20 \mathrm{~cm}$. O desvio padrão obtido foi de 2,708 e o coeficiente de variação, de $11 \%$.

Para a resistência média à compressão axial da argamassa usada para projeção, o "Critério de Chauvenet" forneceu para as pastilhas o valor de 27,9 $\mathrm{MPa}$ e de 56,2 MPa para os corpos-de-prova cilíndricos, resultando uma relação de 0,496 entre esses dois valores. Portanto, como o fator de forma obtido por esse mesmo critério propõe uma relação de 0,625 entre resistência da pastilha e a do corpo-deprova, a diferença de 0,129 pode ser explicada pelas más condições de adensamento das amostras projetadas, intrínsecas ao processo de projeção.

Fazendo-se a mesma analogia, usando o critério de "Desclassificação da Pastilhas Defeituosas ou Não-Representativas”, a resistência média das pastilhas projetadas resultou em 29,8 MPa, sendo de 56,2MPa o valor referente aos corpos-de- 
prova cilíndricos moldados com a mesma argamassa, resultando uma relação de 0,530. Portanto, como o fator de forma obtido por esse mesmo critério propõe uma relação de 0,645 entre as resistências da pastilha e do corpo-de-prova, tem-se uma diferença de 0,115 entre essas relações.

Tomando-se por base o critério de Chauvenet, a resistência das pastilhas projetadas apresentou-se $20 \%$ menor que a das pastilhas extraídas de corpos-deprova cilíndricos de $10 \mathrm{~cm}$ x $20 \mathrm{~cm}$, moldados segundo a Norma Brasileira.

$$
\left(1-\frac{0,496}{0,625}\right) \times 100=20 \% \text {. }
$$

Essa diferença reflete principalmente o modo de execução das placas das quais foram extraídas as pastilhas, tornando-se uma referência para determinação da resistência à compressão da argamassa projetada. A análise dos resultados obtidos indica que a resistência da argamassa projetada é de aproximadamente $80 \%$ da resistência à compressão de um corpo-de-prova de $10 \mathrm{~cm}$ x $20 \mathrm{~cm}$, moldado com a mesma argamassa usada na projeção. 


\section{ANÁLISE EXPERIMENTAL DE VIGAS T}

Foram moldadas duas vigas $\mathrm{T}$, com a mesa e a alma constituídas por elementos tipo sanduíche. Antes da confecção dos modelos, algumas composições básicas foram estudadas para a seção da viga, escolhendo-se os dois modelos ora descritos.

\subsection{DESCRIÇÃO DO MODELO EXPERIMENTAL}

A primeira viga confeccionada (VT 01, ver fig.6.1) serviu para ensaio piloto, o qual permitiu programar melhor o ensaio do modelo VT 02.

A viga T simula, nesse estudo, uma ligação de dois elementos tipo sanduíche, como o contraforte de um muro de arrimo, por exemplo. Propôs-se, então, aplicar nos modelos o mesmo nível de carregamento de um arrimo hipotético, com as seguintes características:

- Aterro de solo não coesivo;

- Peso específico do solo $\gamma=18 \mathrm{kN} / \mathrm{m}^{3}$;

- Terrapleno de superfície horizontal;

- Tensão admissível do solo $\bar{\sigma}=0,2 M P a$;

- Ângulo de atrito interno $\phi=30^{\circ}$;

- Coeficiente de atrito sapata/solo $\mu=\operatorname{tg} 30^{\circ}$;

- Altura do fundo da sapata ao topo do muro $\mathrm{H}=3 \mathrm{~m}$.

Imaginou-se ainda para esse muro de arrimo a colocação de contrafortes a cada dois metros. Adotando-se esses parâmetros, resulta em cada contraforte um momento máximo de cálculo $\mathrm{M}_{\mathrm{d} \text {,máx }}=84,26 \mathrm{kNm}$. 
Para esse momento, o dimensionamento da viga $\mathrm{T}$ foi feito utilizando-se as mesmas hipóteses empregadas no cálculo usual de concreto armado, considerando-se a seção resistente efetiva.

O ensaio do modelo VT 01 é descrito no ANEXO C. Nesse ensaio piloto foram feitas importantes observações, que serviram para definir tanto as dimensões como a configuração de ligação mesa-alma do modelo VT 02. As modificações foram basicamente as seguintes:

- Colocação de uma armadura de cisalhamento mais reforçada;

- Aumento da largura da mesa;

- Aumento da altura da alma;

- Aumento da espessura do revestimento de $2,5 \mathrm{~cm}$ para $3 \mathrm{~cm}$.
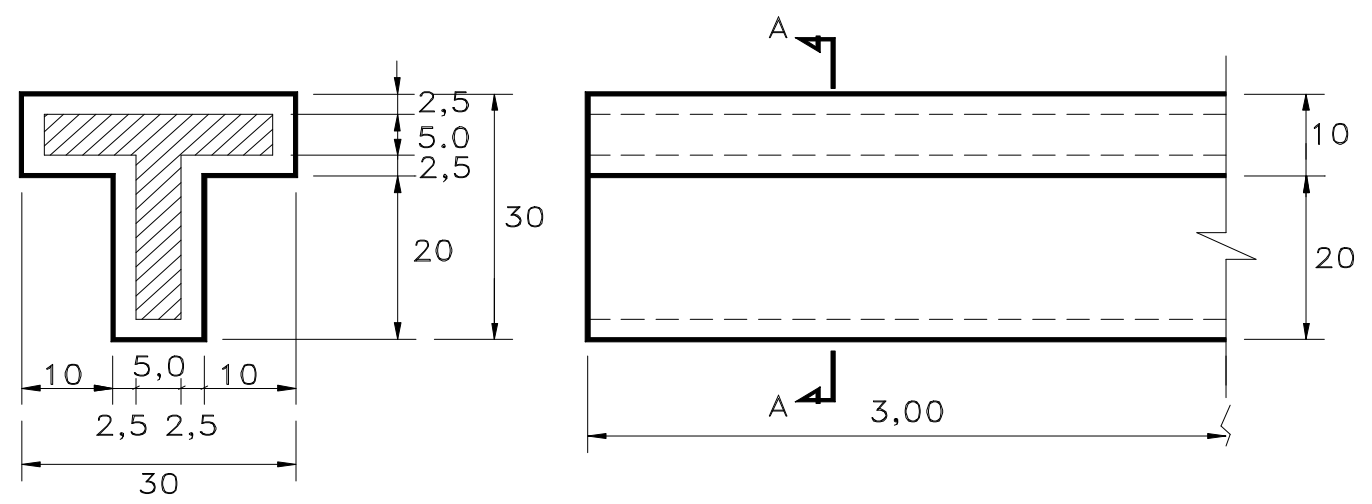

FIGURA 6.1 - DIMENSÕES DA VIGA T - MODELO VT 01

Além disso, para melhorar a conexão entre os elementos da viga, preencheuse com argamassa a interseção mesa-alma, criando-se nesse lugar um núcleo maciço.

As dimensões da viga (modelo VT 02) são mostradas na fig.6.2. A largura da mesa é de $71 \mathrm{~cm}$ e a altura da alma de $30 \mathrm{~cm}$. A espessura média das placas de argamassa é de $3 \mathrm{~cm}$ e a espessura do núcleo de $5 \mathrm{~cm}$. A espessura total, tanto da mesa como da alma, é de $11 \mathrm{~cm}$. O comprimento da viga é de $300 \mathrm{~cm}$. 


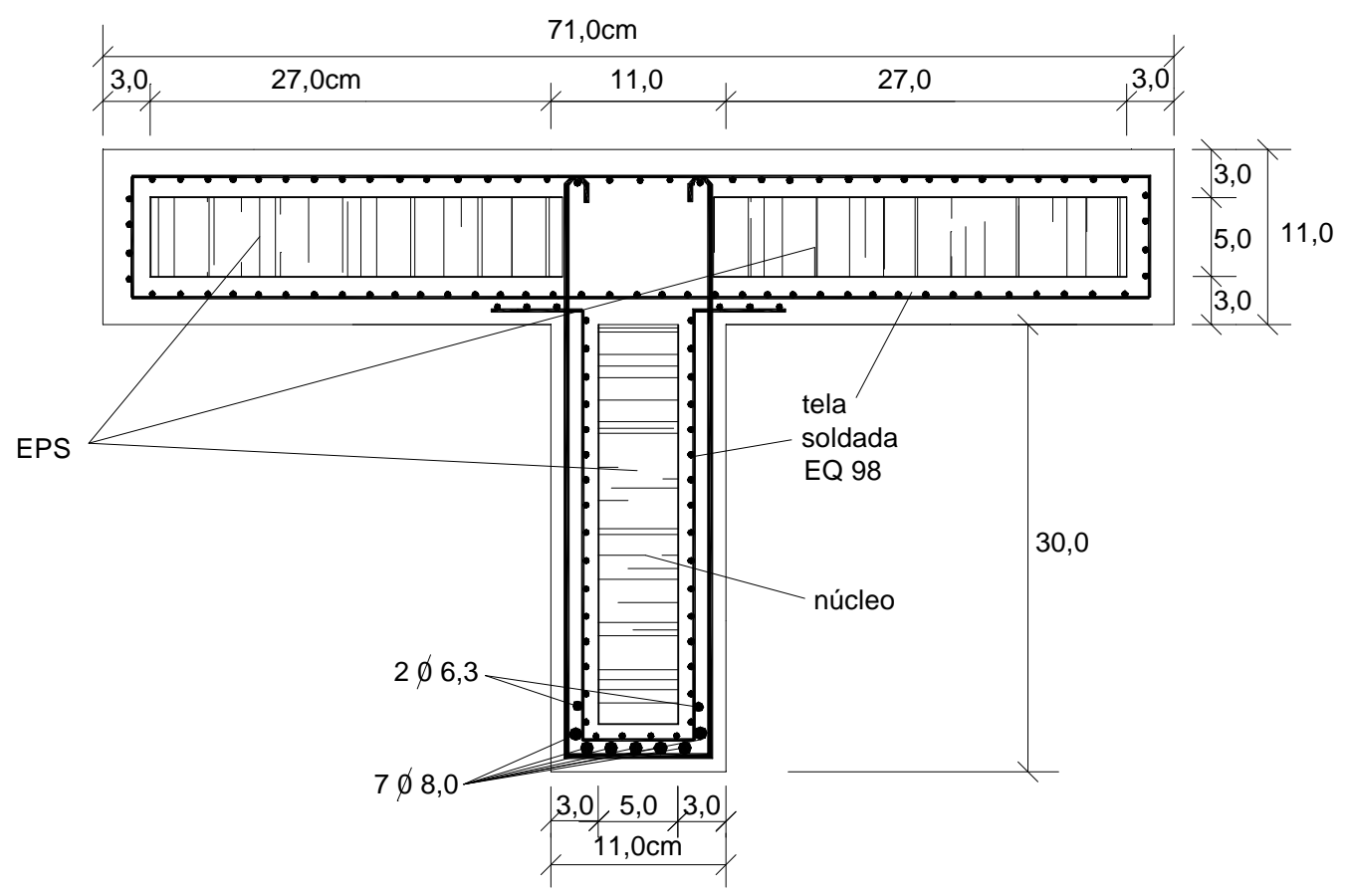

FIGURA 6.2 - DIMENSÕES DA VIGA T - MODELO VT 02

\subsection{MATERIAIS EMPREGADOS}

Apresentam-se as informações sobre os materiais utilizados: argamassa, armadura e núcleo

\subsubsection{Argamassa}

O traço da argamassa foi o obtido experimentalmente, conforme descrito no ANEXO A. As proporções forneceram uma argamassa projetável, tanto manualmente como através da caneca de projeção. Foi empregado o cimento Portland de alta resistência inicial - CPV-ARI PLUS, marca Ciminas. Utilizou-se o superplastificante marca Reax 3000 e sílica ativa marca Silmix. A resistência média à compressão, no dia do ensaio, foi $\mathrm{f}_{\mathrm{cj}}=57,42 \mathrm{MPa}$, e o módulo de elasticidade, foi $\mathrm{E}=30.000 \mathrm{MPa}$, obtidos no ensaio de compressão de corpos-de-prova cilíndricos de $10 \mathrm{~cm} \times 20 \mathrm{~cm}$.

A relação cimento/areia foi de $1: 3$, com adição de $2 \%$ de superplastificante (SP) e $10 \%$ de sílica ativa (SA). O fator água-cimento foi $\mathrm{a} / \mathrm{c}=0,51$. As porcentagens são tomadas em função do peso do cimento. A utilização da sílica ativa 
melhorou algumas características da argamassa, tais como: coesão, resistência e compacidade.

Como agregado miúdo utilizou-se areia natural, enquadrada como areia média, dentro dos limites granulométricos especificados pela NBR 7211(1983). Foram feitos os ensaios de caracterização da areia, obtendo-se para massa específica real um valor de $2,62 \mathrm{~g} / \mathrm{cm}^{3}$ e para a massa unitária o valor de 1,51 .

\subsubsection{Armadura: tipo e disposição}

Para o lote de aço foram determinados os limites de escoamento e de ruptura, o módulo de elasticidade e o diagrama tensão-deformação (fig.6.3 e 6.4). Os ensaios de tração foram realizados conforme a NBR 6152 (1992), utilizando controle de deslocamento de $0,03 \mathrm{~mm} / \mathrm{s}$, através da máquina universal de ensaios marca DARTEC, com capacidade de $100 \mathrm{kN}$. Os resultados encontram-se na tabela 6.1 .

TABELA 6.1 - Propriedades das barras de aço

\begin{tabular}{|c|c|c|c|}
\hline $\begin{array}{c}\text { Diâmetro da barra } \\
(\mathrm{mm})\end{array}$ & $\begin{array}{c}\text { Limite de Escoamento } \\
(\mathrm{MPa})\end{array}$ & $\begin{array}{c}\text { Limite de Ruptura } \\
(\mathrm{MPa})\end{array}$ & $\begin{array}{c}\text { Módulo de Elasticidade } \\
(\mathrm{MPa})\end{array}$ \\
\hline 6,3 & 580,64 & 796,64 & $178.705,2$ \\
\hline 8,0 & 554,40 & 644,58 & $173.071,2$ \\
\hline
\end{tabular}

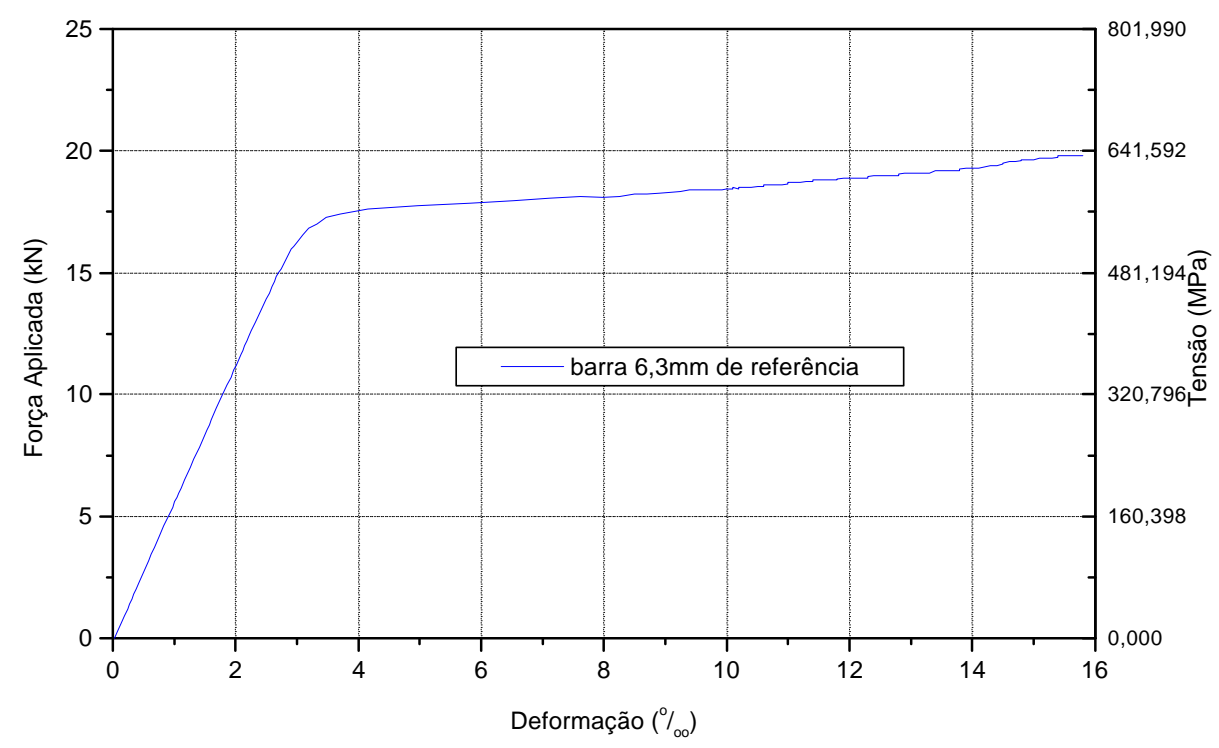

FIGURA 6.3 - DIAGRAMA FORÇA X DEFORMAÇÃO DA BARRA DE 6.3MM 


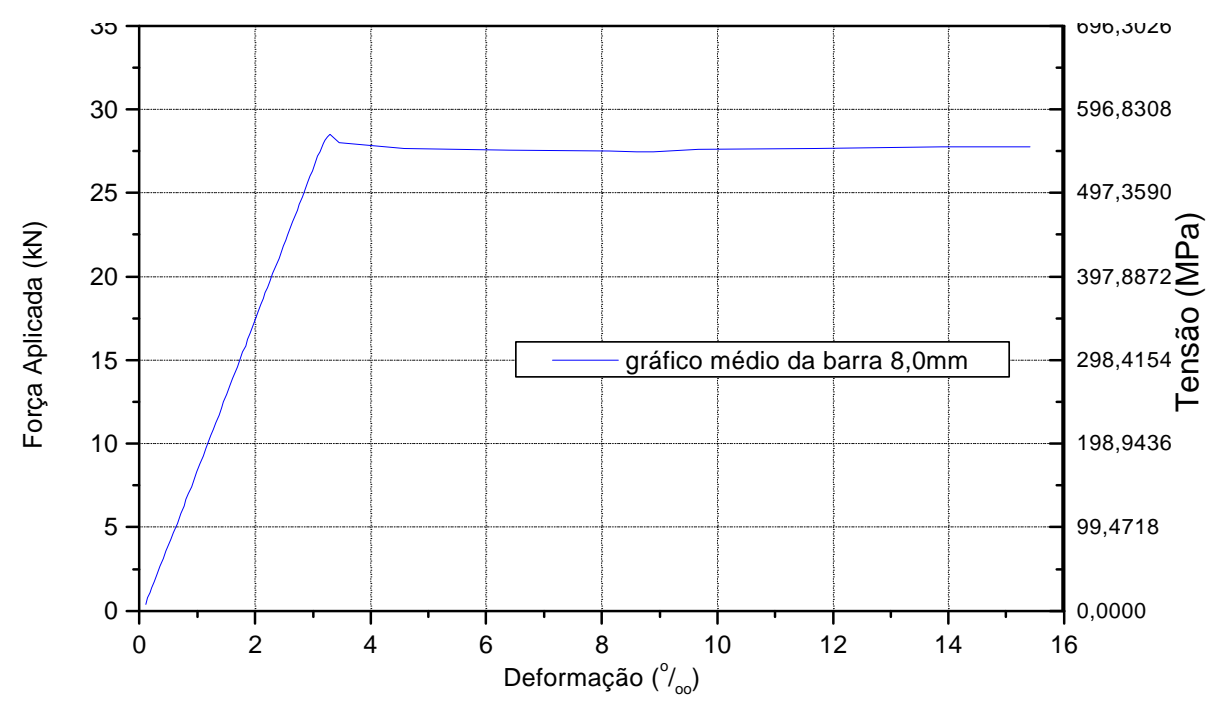

FIGURA 6.4 - DIAGRAMA FORÇA X DEFORMAÇÃO DA BARRA DE 8MM

Na confecção do modelo VT 02 foram utilizadas telas soldadas e barras de aço como armadura de reforço. A especificação da tela é EQ98, de aço CA60, com diâmetros dos fios de $2,5 \mathrm{~mm}$ e espaçamentos de $5 \mathrm{~cm}$ entre fios longitudinais e os transversais.

A tela foi cortada e dobrada da maneira mostrada na fig.6.5.

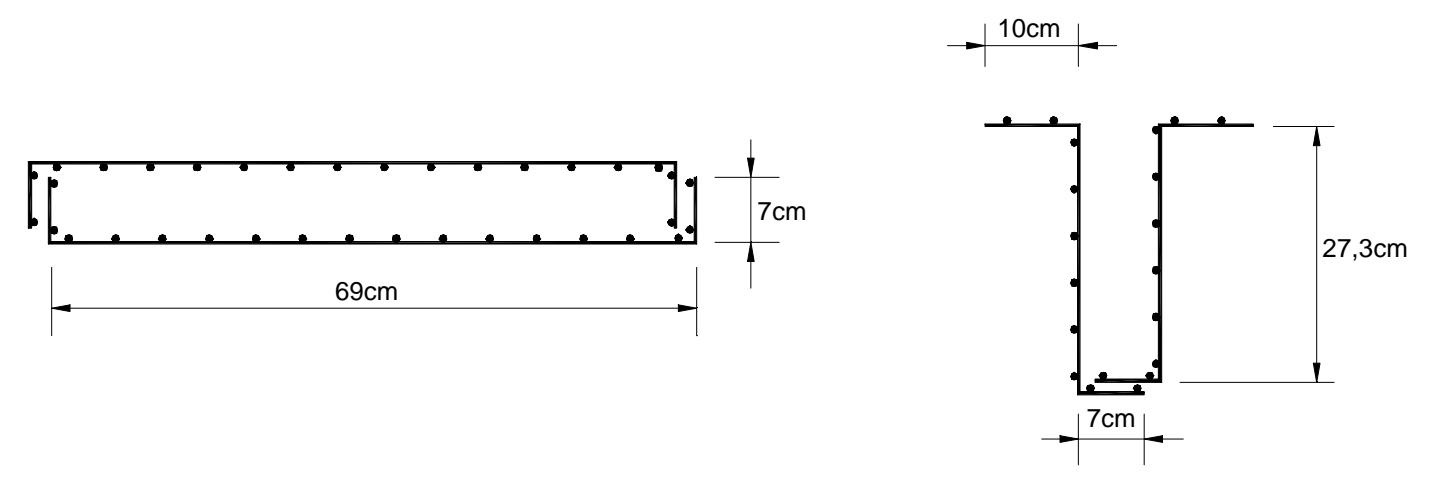

FIGURA 6.5 - DETALHE DE CORTE E DOBRAMENTO DA TELA SOLDADA

Como armadura de tração foram utilizadas nove barras de aço, sendo duas com diâmetro de $6,3 \mathrm{~mm}$ e cinco com diâmetro de $8 \mathrm{~mm}$. A distribuição das barras é mostrada na fig.6.6. 


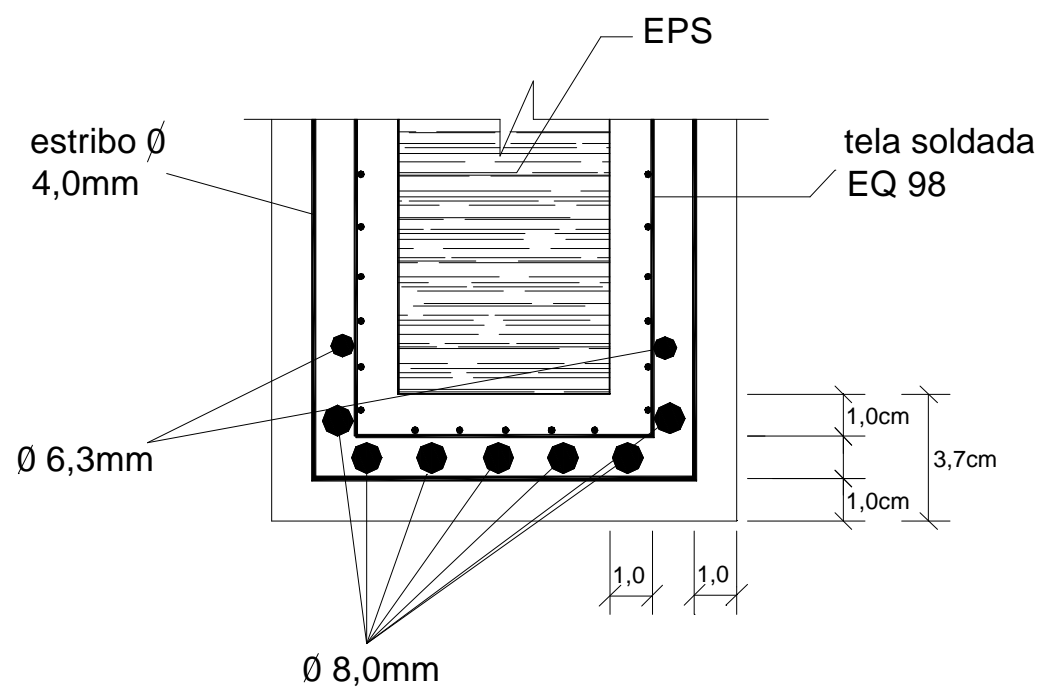

FIGURA 6.6 - POSICIONAMENTO DA ARMADURA DE TRAÇÃO NA VT 02

Utilizaram-se estribos com diâmetro de $4 \mathrm{~mm}$, distribuídos nos terços mais próximos dos apoios a cada $7 \mathrm{~cm}$ e no terço central a cada $15 \mathrm{~cm}$. O detalhe do dobramento dos estribos é mostrado na fig.6.7.

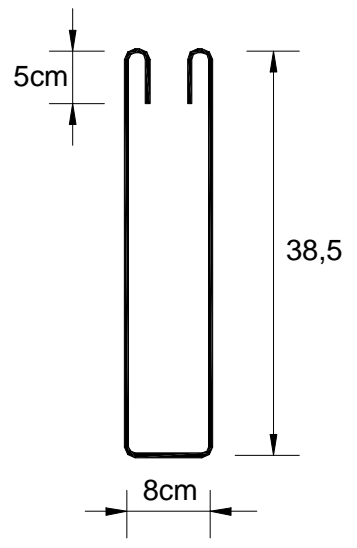

FIGURA 6.7 - DETALHE DO DOBRAMENTO DOS ESTRIBOS

\subsubsection{Núcleo}

Como material do núcleo foram utilizadas placas com 50mm de espessura, de poliestireno expandido (EPS), popularmente conhecido como isopor. O painel de EPS para o modelo VT 02 foi cortado nos tamanhos mostrados na fig.6.8. 
Placa 1 - mesa da viga $\mathrm{T}$

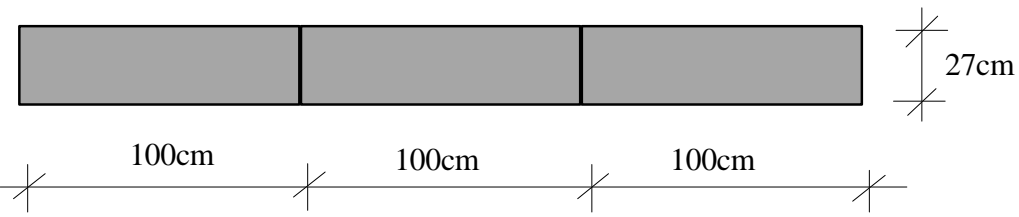

Placa 2 - alma da viga $\mathrm{T}$

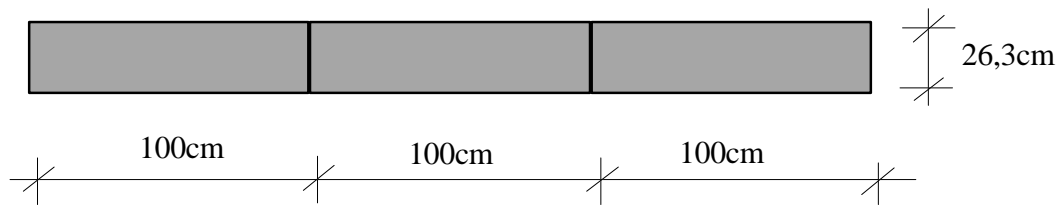

FIGURA 6.8 - CORTE DAS PLACAS DE EPS (VT 02)

\subsection{CONFECÇÃO DA VIGA T}

As confecções dos dois modelos não tiveram a mesma sequiência. Pôde-se aproveitar a experiência adquirida com o primeiro modelo, para a execução do segundo, eliminando-se assim alguns erros construtivos e alguns problemas verificados na execução do primeiro modelo, como, por exemplo: cobrimento da tela soldada, distanciamento correto do EPS à armadura, fissuras por retração da argamassa e fissuras ao longo da interseção da primeira com a segunda camada de argamassa.

\subsubsection{Montagem da armadura}

Inicialmente, as partes da tela soldada foram recortadas, dobradas e amarradas com arame, formando o "esqueleto" da viga $\mathrm{T}$, conforme indicado na fig.6.9. Após essa montagem, as placas de EPS foram colocadas no interior do "esqueleto".

Para garantir o distanciamento de $1 \mathrm{~cm}$ entre as telas e as placas de EPS, foram usados pedaços de fios de $4 \mathrm{~mm}$ de diâmetro, que atravessavam o EPS num ângulo de aproximadamente $45^{\circ}$ e que eram fixados nas telas por meio de arame.

Em seguida, as barras longitudinais foram colocadas na região inferior da alma. Após essa etapa é que foram colocados os estribos, concluindo a montagem da armadura. As figuras 6.9, 6.10 e 6.11 mostram os detalhes da armação da viga. 


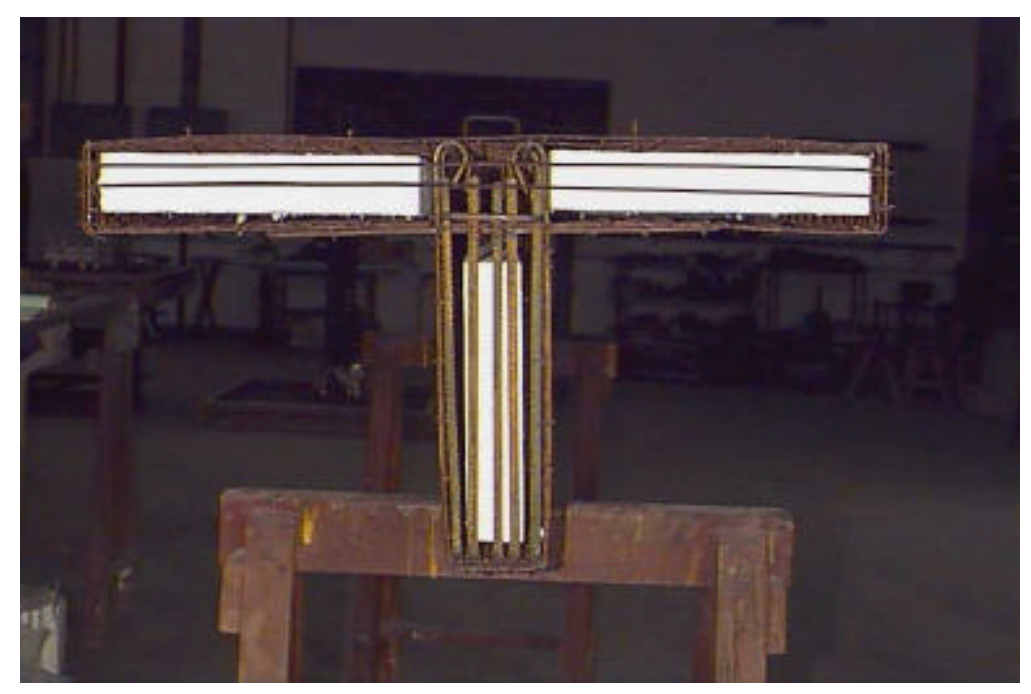

FIGURA 6.9 - SEÇÃO TRANSVERSAL DA ARMAÇÃO DA VIGA

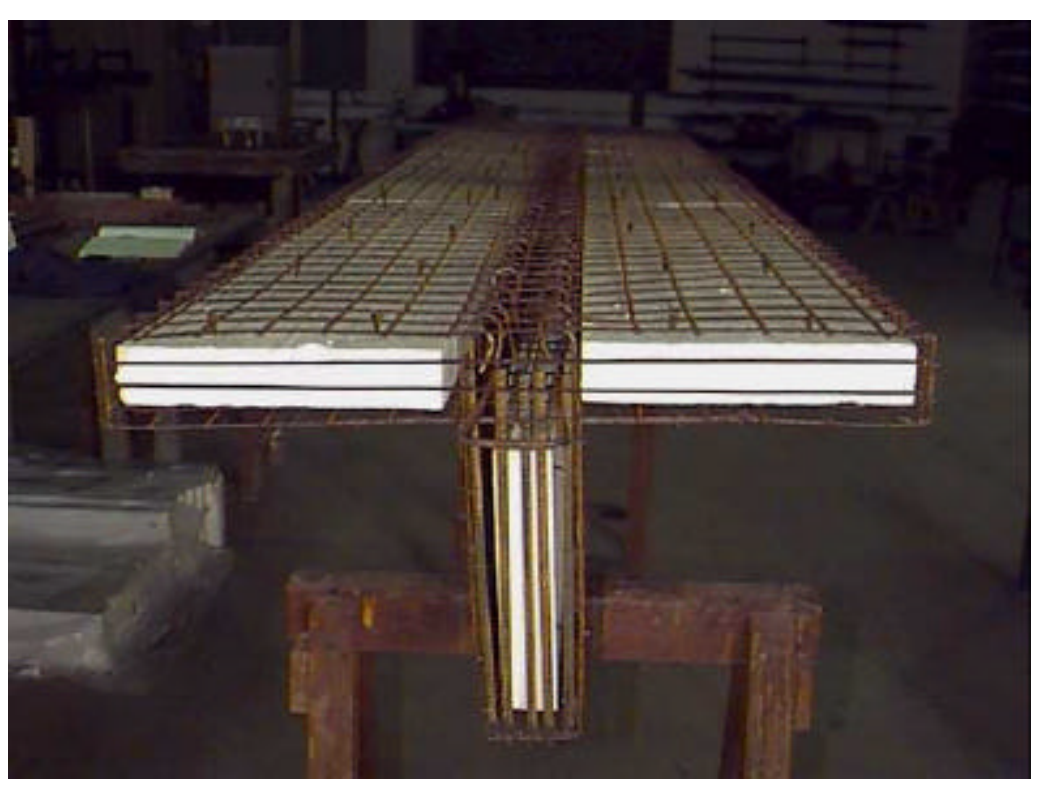

FIGURA 6.10 - DETALHE DOS ESTRIBOS E DA INTERSECÇÃO DOS ELEMENTOS SANDUÍCHE 


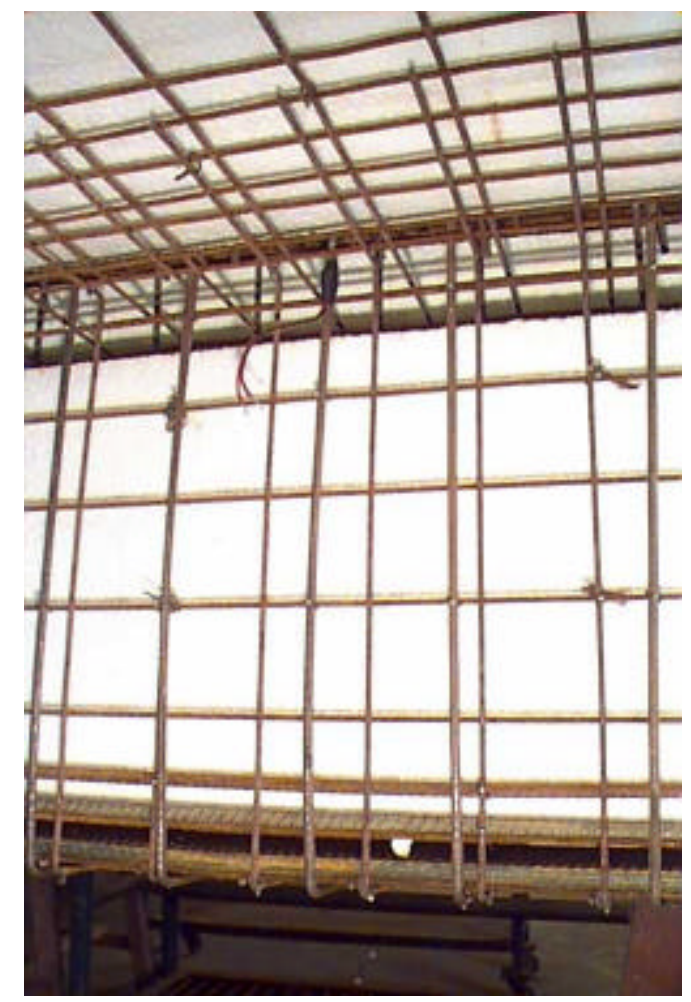

FIGURA 6.11 - DETALHE DA CONEXÃO ENTRE A TELA DA ALMA E A TELA DA MESA. DISTRIBUIÇÃO DA ARMADURA DE TRAÇÃO

\subsubsection{Argamassagem da viga}

Procurou-se efetuar a argamassagem da peça em duas camadas, de modo que em cada etapa fosse aplicada argamassa de mesma idade em toda a superfície da viga, evitando-se assim fissuras de retração, na interface de argamassas de idades diferentes. Para que isto fosse possível, argamassou-se a viga na posição vertical. A primeira etapa da argamassagem foi efetuada de modo a se preencher o espaço entre a placa de EPS e a tela. Na segunda etapa foi concluída a argamassagem, garantindose um cobrimento de $1 \mathrm{~cm}$ da armadura e um adequado acabamento da superfície. As figuras 6.12 a 6.17 mostram as fases da argamassagem da viga. 


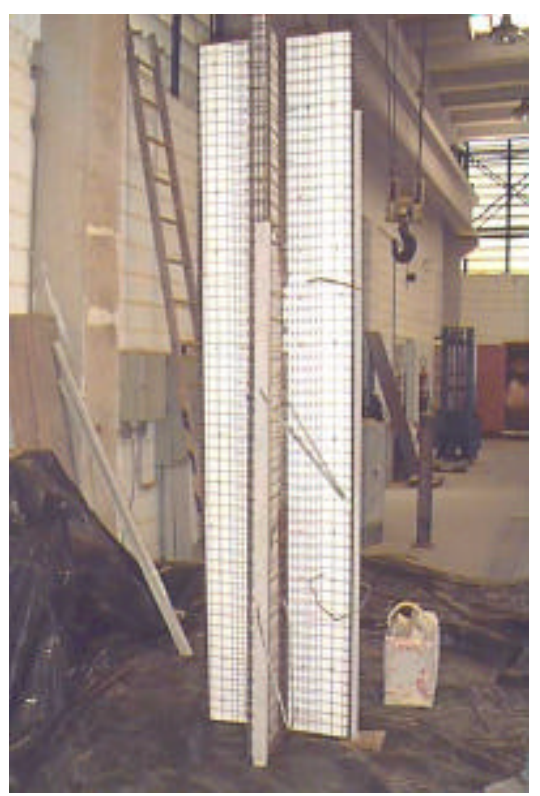

FIGURA 6.12 - VIGA NA POSIÇÃO VERTICAL, PREPARADA PARA O INÍCIO DA ARGAMASSAGEM
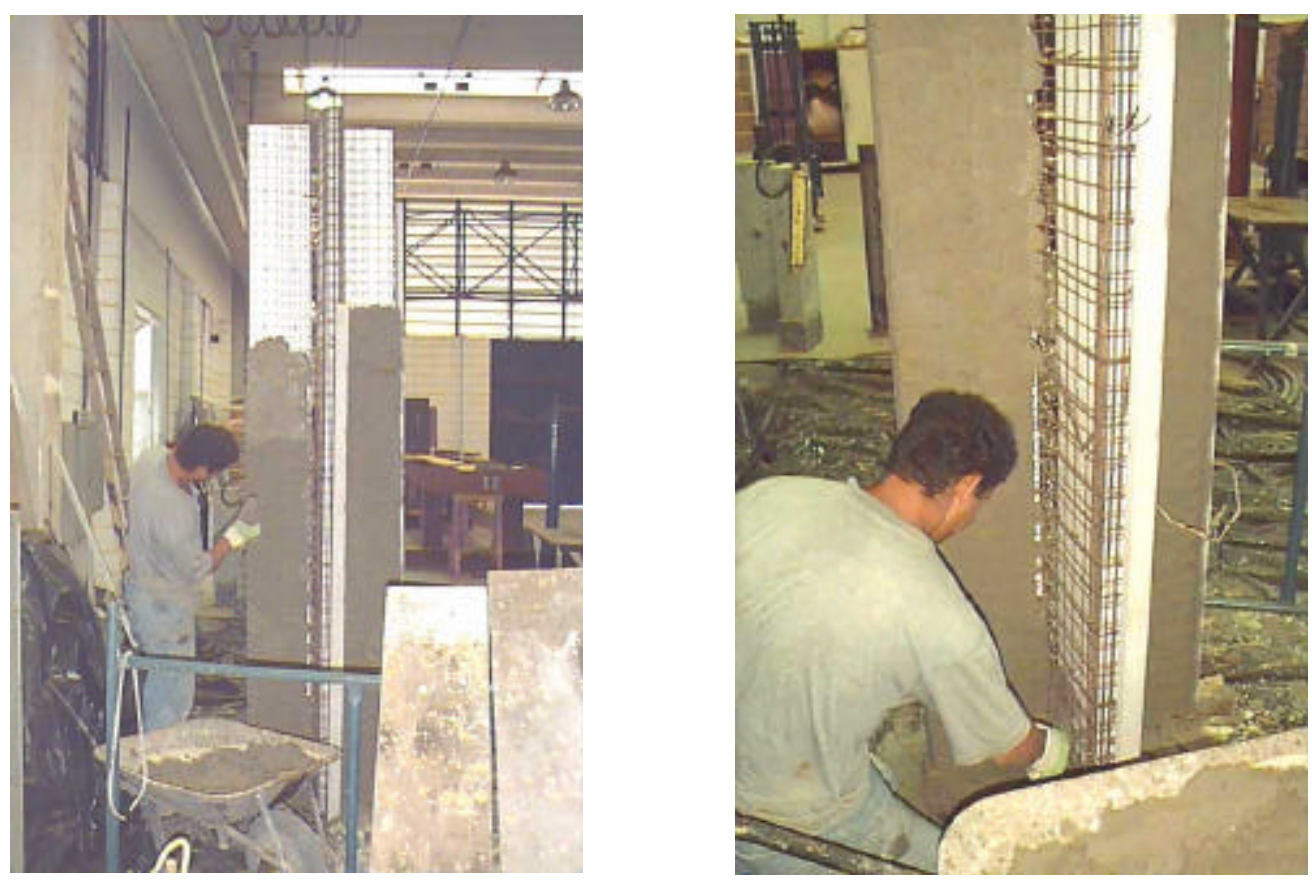

FIGURA 6.13 - ARgAMASSAGEM DA MESA E DA ALMA. PRIMEIRA ETAPA 


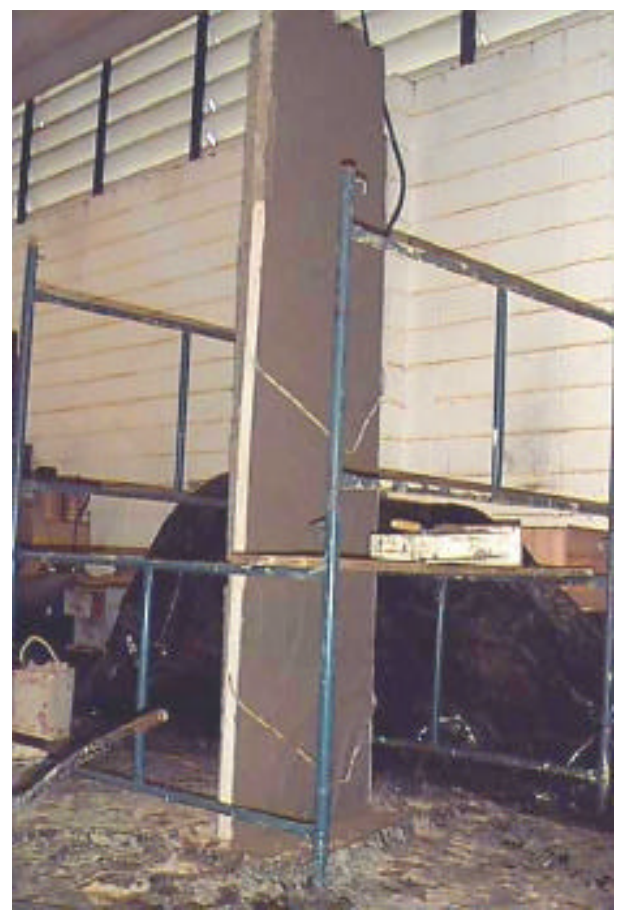

FIGURA 6.14 - FINAL DA PRIMEIRA ETAPA DA ARGAMASSAGEM

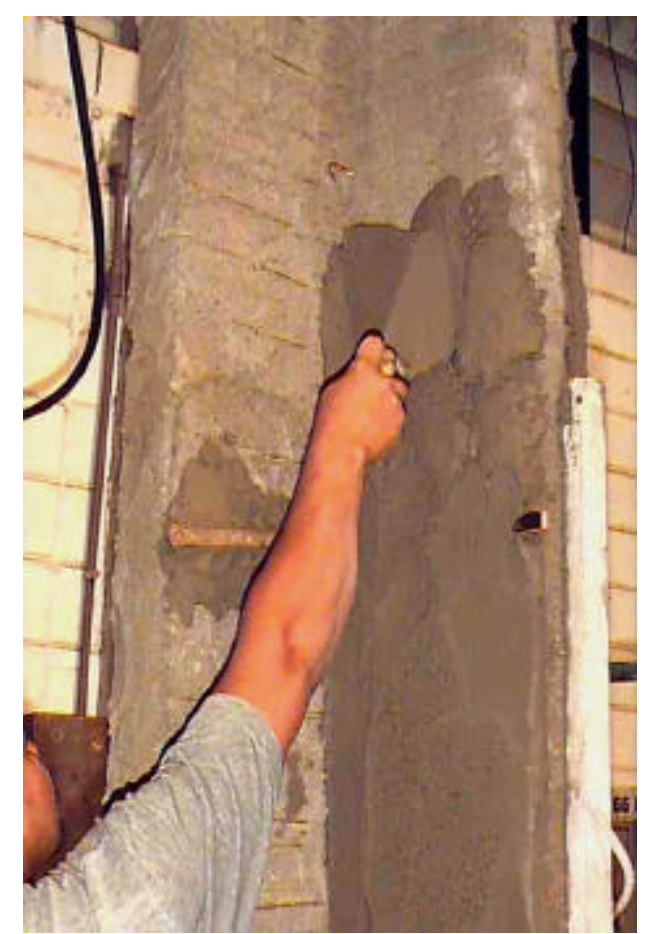

FIGURA 6.15 - INÍCIO DA SEGUNDA ETAPA DA ARGAMASSAGEM 


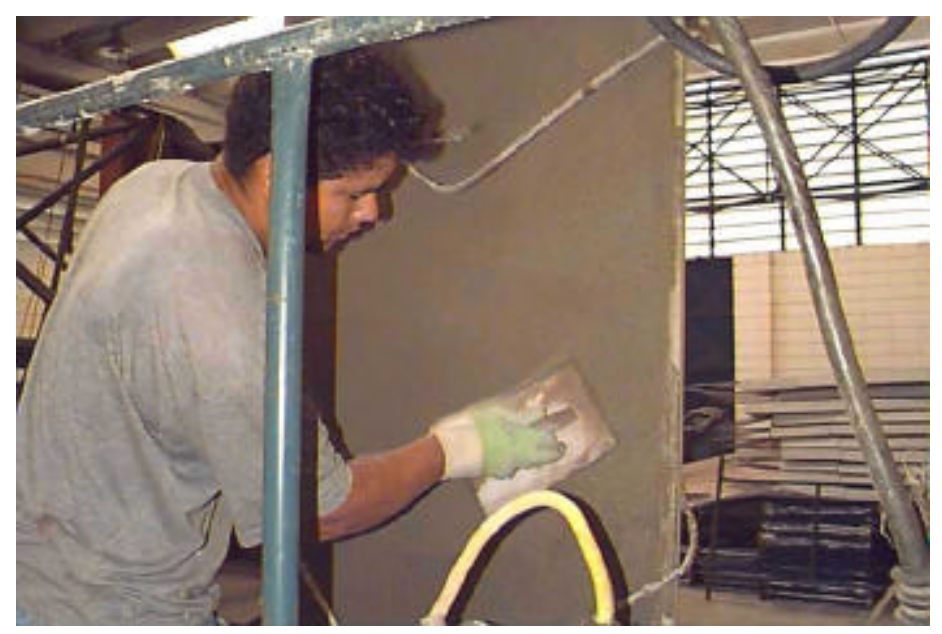

FIGURA 6.16 - FASE DE ACABAMENTO

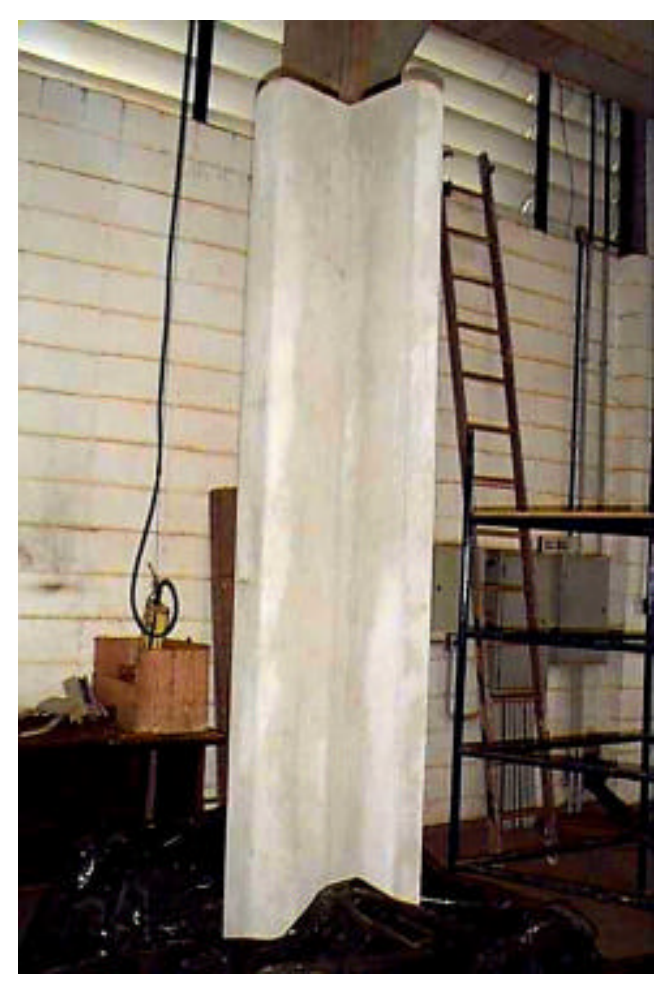

FIGURA 6.17 - VIGA PRONTA

\subsection{ESQUEMA ESTÁTICO, CARREGAMENTO E INSTRUMENTAÇÃO}

O esquema estático adotado foi o de uma viga simplesmente apoiada, submetida a carregamento nos terços do vão.

Para o modelo VT 01, a força foi aplicada em incrementos de $5 \mathrm{kN}$, por meio de um cilindro hidráulico acoplado em uma bomba hidráulica de acionamento manual. Para os dois modelos, os deslocamentos foram medidos em cinco pontos, 
utilizando-se transdutores elétricos, de sensibilidade de $0,05 \mathrm{~mm}$, curso de $100 \mathrm{~mm}$, marca Kywoa, modelo DT 100 A.

A fig.6.18 mostra o esquema estático e de carregamento, bem como o posicionamento dos transdutores para os dois modelos.

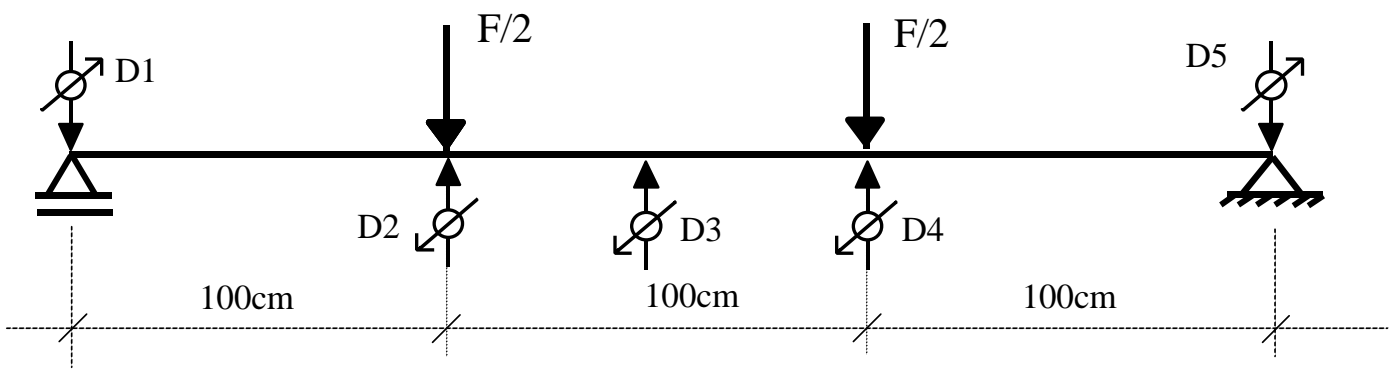

FIGURA 6.18 - ESQUEMA ESTÁTICO, CARREGAMENTO E INSTRUMENTAÇÃO - VT 01 E VT 02

Para o modelo VT 02, a força foi aplicada em incrementos de $2 \mathrm{kN}$, até uma carga de $220 \mathrm{kN}$, através de um cilindro hidráulico acoplado a uma bomba hidráulica de acionamento mecânico. Para registro das leituras indicadas na célula de carga de capacidade de $500 \mathrm{kN}$, utilizou-se um sistema de aquisição de marca Measurements Group, modelo System 5000.

A figura 6.19 mostra o modelo VT 02 pronto para o inicio do ensaio.

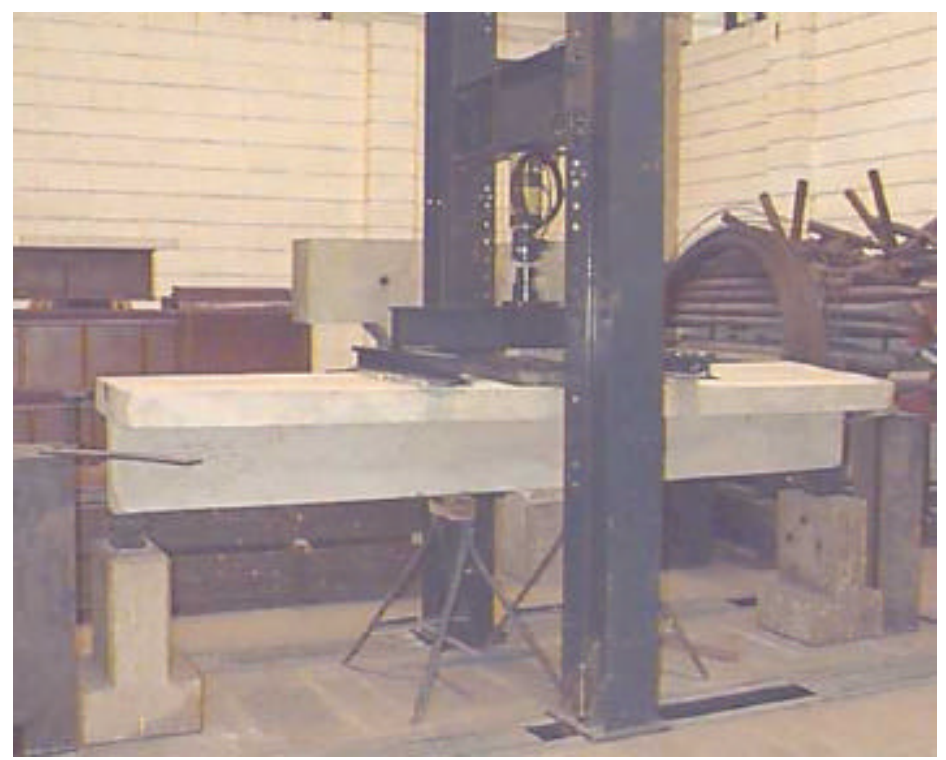

FIGURA 6.19 - Modelo VT 02. DETALHE DO APOIO E DO MECANISMO DE APLICAÇÃO DE CARGA: MACACO HIDRÁULICO E PÓRTICO DE REAÇÃO 
As deformações em vários pontos da mesa, na armadura de tração e na armadura de cisalhamento, foram medidas somente para o modelo VT 02. A disposição dos extensômetros é mostrada na fig.6.20. Utilizaram-se extensômetros elétricos de resistência, colados na argamassa e na armadura. Para os colados na argamassa, tinham por base $10 \mathrm{~mm}$, marca Kywoa e modelo KGF-10-C1-11. Para os colados no aço, tinham por base 5mm e modelo KGF-5-C1-11.

EXTENSÔMETROS NA ARGAMASSA E5-E15

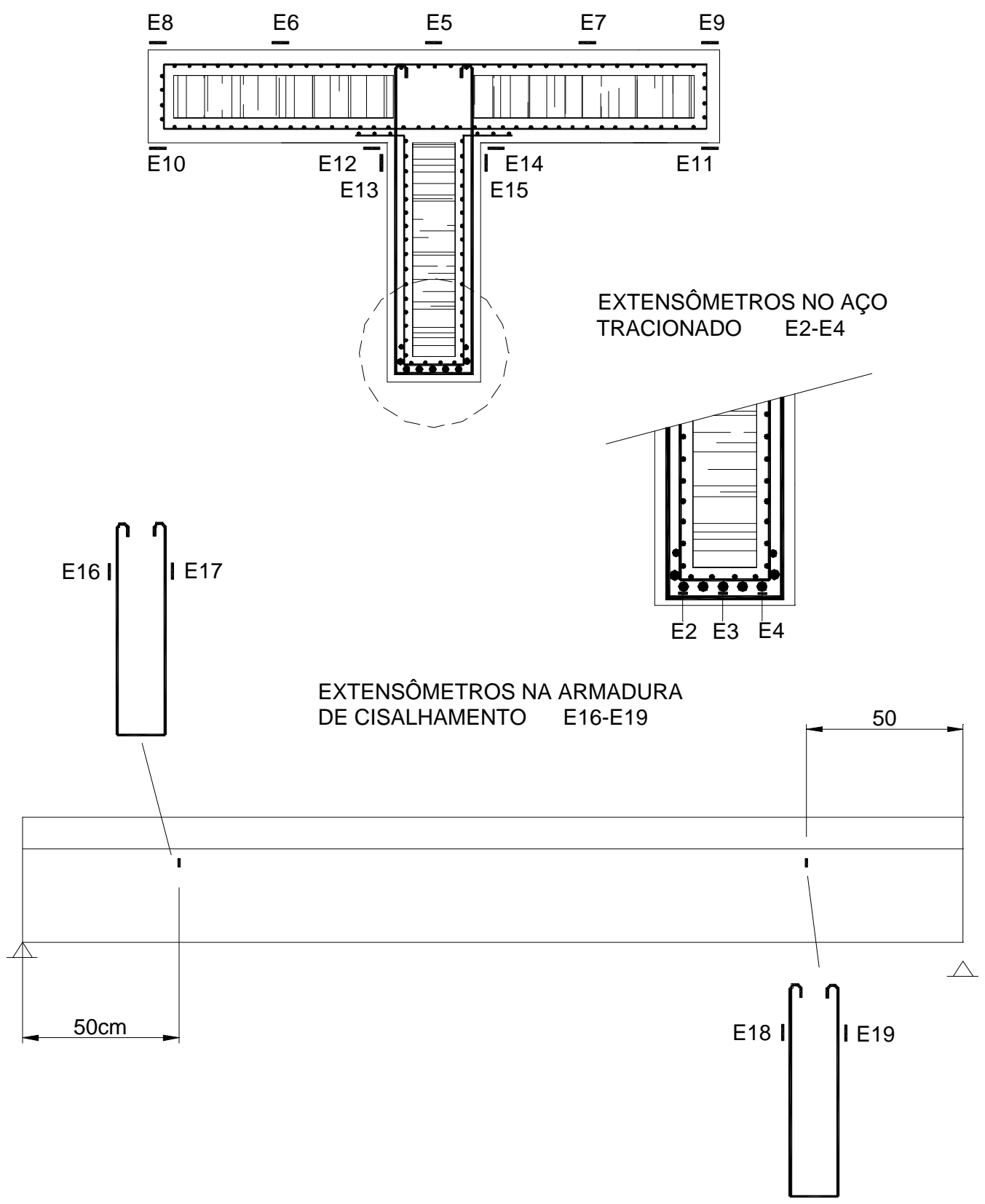

FIGURA 6.20 - POSICIONAMENTOS DOS EXTENSÔMETROS 


\subsection{RESULTADOS OBTIDOS E ANÁLISE DOS RESULTADOS}

Serão considerados os momentos de fissuração e de ruptura, os deslocamentos e a força cortante.

\subsubsection{Momento de fissuração}

O momento de fissuração $\left(M_{r}\right)$ é o momento fletor capaz de provocar a primeira fissura na peça. Segundo o anexo da NBR 7197 (1989), seu cálculo é feito no estádio I, considerando diagrama triangular de tensões no concreto. A tensão na fibra mais tracionada é dada por:

$$
\sigma_{\mathrm{t}}=\frac{\mathrm{M}}{\mathrm{I}} \mathrm{y}=\frac{\mathrm{M}}{\mathrm{I}}(\mathrm{h}-\mathrm{x}),
$$

Rearranjando e tirando o valor do momento M, tem-se:

$$
\mathrm{M}=\frac{\sigma_{\mathrm{t}} \mathrm{I}}{\mathrm{h}-\mathrm{x}}
$$

Substituindo o valor da resistência à tração, determina-se o momento de fissuração $\mathrm{M}_{\mathrm{r}}$ :

$$
M_{r}=\frac{f_{c t m} I}{h-x},
$$

onde:

$\mathrm{f}_{\mathrm{ctm}}$ : resistência média do concreto à tração na flexão;

$\mathrm{f}_{\mathrm{ctm}}=\left\{\begin{array}{cl}1,2 \mathrm{f}_{\mathrm{ctk}} & \text { para seção } \mathrm{T} \text { ou duplo } \mathrm{T} \\ 1,5 \mathrm{f}_{\mathrm{ctk}} & \text { para seção retangular }\end{array}\right.$

$\mathrm{f}_{\text {ctk }}$ : resistência característica do concreto à tração

$\mathrm{Na}$ ausência de dados experimentais, pode-se utilizar os seguintes valores para a resistência à tração:

$f_{c t k}= \begin{cases}f_{c k} / 10 & \text { para } f_{c k} \leq 18 \mathrm{MPa} \\ 0,06 f_{c t k}+0,7 \mathrm{MPa} & \text { para } f_{c k}>18 \mathrm{MPa}\end{cases}$

$\mathrm{f}_{\mathrm{ck}}$ : resistência característica do concreto à compressão;

I, x: momento de inércia e posição da linha neutra da peça não-fissurada (estádio I), considerando-se seção homogeneizada e razão entre os módulos de elasticidade 
do aço e do concreto $\left(\alpha_{\mathrm{e}}\right)$ igual a 10 (combinação rara) ou 15 (combinação freqüiente ou quase permanente);

h: altura da seção.

Para a seção efetiva considerada da viga VT 02 e a resistência à tração $f_{c t k}$ (ou simplesmente $\mathrm{f}_{\mathrm{tk}}$ ) com a expressão (6.3), determina-se o valor de $\mathrm{M}_{\mathrm{r}}$.

A resistência característica da argamassa à tração $\mathrm{f}_{\text {tk }}$, calculada pela eq.(6.4), é igual a 4,15 MPa.

Calculando-se o momento de inércia I e a posição linha neutra $x$ da peça nãofissurada (estádio I), considerando-se seção homogeneizada com $\alpha_{e}=6$ (obtido dos resultados experimentais), e substituindo-se em (6.3), obtém-se para o valor do momento de fissuração teórico $\mathrm{M}_{\mathrm{r} \text {,teo }}=19,2 \mathrm{kNm}$. $\mathrm{O}$ valor experimental obtido no ensaio foi de $\mathrm{M}_{\mathrm{r}, \exp }=16,8 \mathrm{kNm}$.

O valor teórico encontrado foi $14 \%$ maior que o valor experimental. No cálculo de $\mathrm{M}_{\mathrm{r}, \text { teo }}$, o valor empregado de $\mathrm{f}_{\mathrm{tk}}$ foi estimado através da eq.(6.4), proposta pela NBR 6118 (1982). Essa expressão forneceu um valor de $f_{\text {tk }}$ relativamente alto em comparação com os obtidos experimentalmente, para valores da resistência à compressão próximos do utilizado no cálculo. Provavelmente, esse fator foi o principal responsável pela diferença encontrada entre $M_{r, \text { teo }}$ e $M_{r, \text { exp }}$.

As figuras 6.21 e 6.22 mostram as configurações das fissuras desenvolvidas ao longo do ensaio.

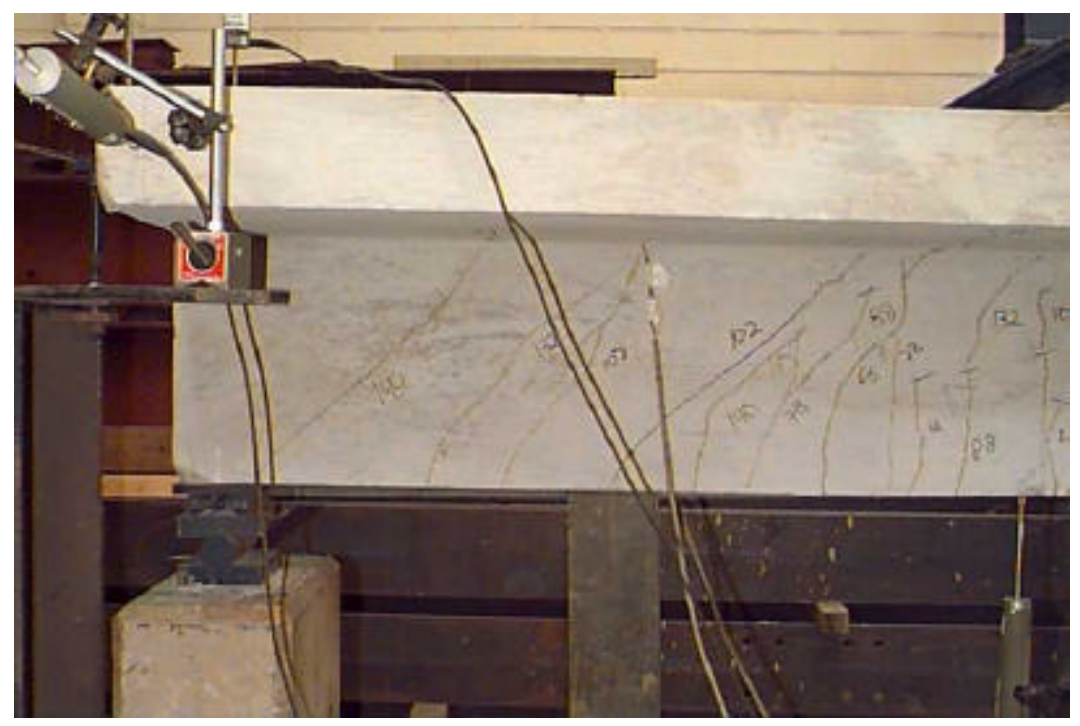

FIGURA 6.21 - CONFIGURAÇÃO DAS FISSURAS PRÓXIMAS AO APOIO - MODELO VT 02 
Como era esperado, as fissuras próximas ao apoio possuem uma inclinação de aproximadamente $45^{\circ}$, que aumentam em relação à direção horizontal à medida que se aproximam do meio da viga. No centro da viga, as fissuras têm direção praticamente vertical. A configuração das fissuras se deu de forma semelhante à de uma viga usual de concreto armado.

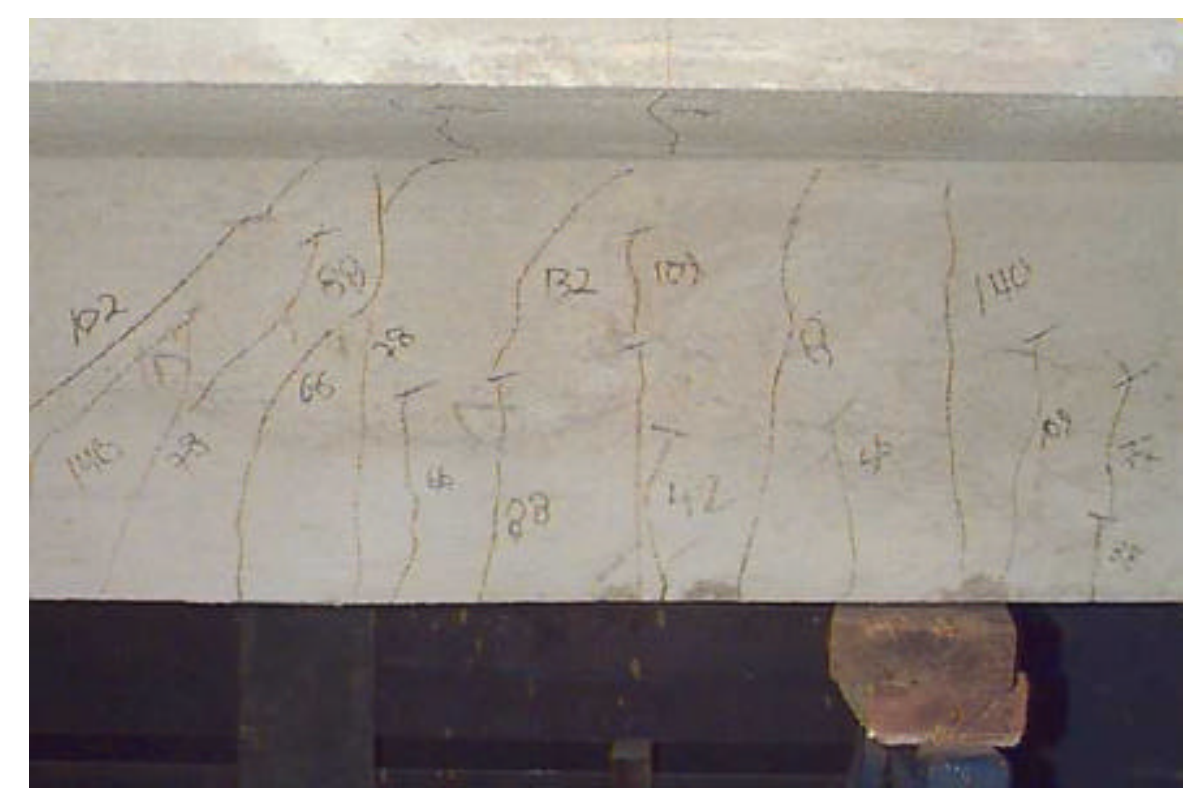

FIGURA 6.22 - CONFIGURAÇÃO DAS FISSURAS NO MEIO DO VÃO DO MODELO VT 02

\subsubsection{Momento de ruptura}

A viga foi dimensionada utilizando as mesmas hipóteses do concreto armado, prescritas pela NBR 6118 (1982). Por ter sido empregada a técnica de projeção da argamassa na execução da viga, utilizou-se o valor reduzido em $20 \%$ da resistência da argamassa à compressão, conforme conclusões obtidas no capítulo 5 desse trabalho. Devido à geometria da seção, o dimensionamento ocorreu no domínio 2 de deformações na ruína $\left(\varepsilon_{\mathrm{s}}=10 \%\right.$ e $\varepsilon_{\mathrm{c}}<3,5 \%$ \% . O carregamento foi interrompido na etapa correspondente à força de $220 \mathrm{kN}$, para a qual, apesar de se verificar o escoamento do aço, a deformação $\varepsilon_{\mathrm{s}}$ não atingiu o valor de $10 \%$ previsto no dimensionamento, como pode ser visto na fig.6.23, que mostra as deformações no aço, medidas através de extensômetros elétricos colados nas barras tracionadas. A disposição dos extensômetros é mostrada na fig.6.20. 


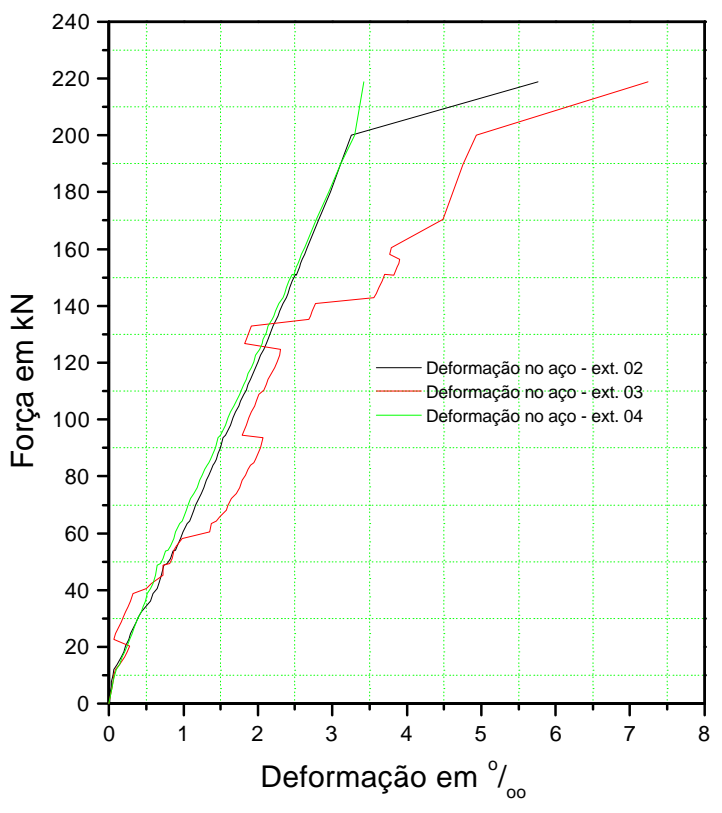

FIGURA 6.23 - DIAGRAMA FORÇA X DEFORMAÇÃO DO AÇO NO ENSAIO DE FLEXÃO

No diagrama apresentado na fig.6.23 observa-se que, se a força continuasse a ser aplicada, as deformações rapidamente atingiriam o limite convencional de $10 \%$, causando ruína por deformação excessiva.

A fig.6.24 mostra as deformações de compressão ao longo da mesa (superfície superior), para algumas etapas de carregamento. Observa-se que a deformação experimental média na ruptura foi de $0,63 \%$, enquanto a deformação teórica, determinada a partir da compatibilidade de deformações no domínio 2, foi de $0,58 \%$.

As diferenças entre as deformações nas bordas e no centro da mesa comprimida, verificadas na fig.6.24, ocorreram pelo enrijecimento proporcionado pelo núcleo maciço que une a mesa à alma da viga e por uma possível ocorrência de esforço de torção.

A fig.6.25 mostra a deformação ao longo da mesa (superfície inferior), para algumas etapas de carregamento. O posicionamento dos extensômetros está indicado na fig.6.20. 


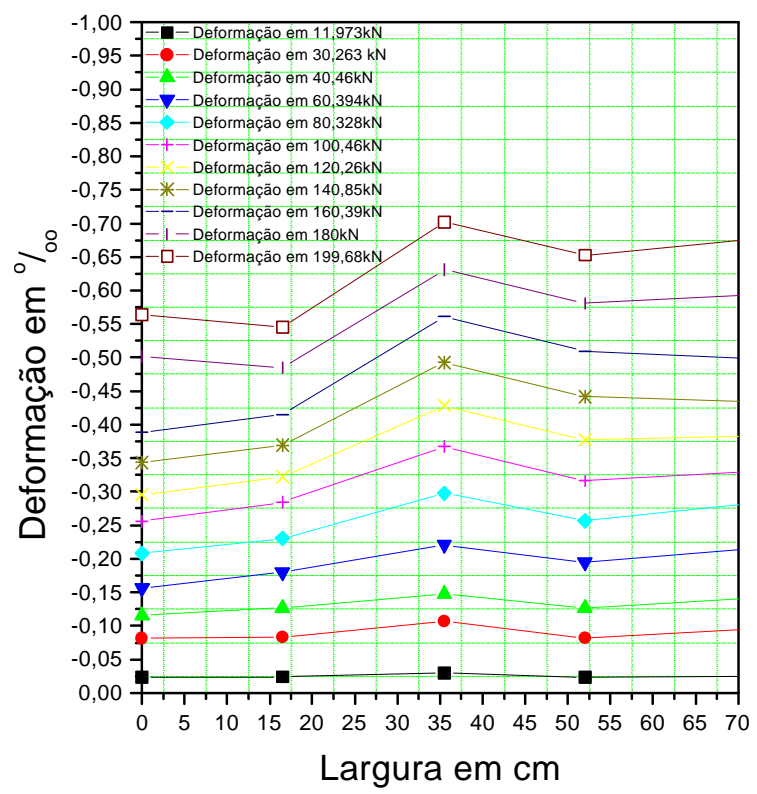

FIGURA 6.24 - DEFORMAÇÕES AO LONGO DA LARGURA - SUPERFÍCIE SUPERIOR DA MESA

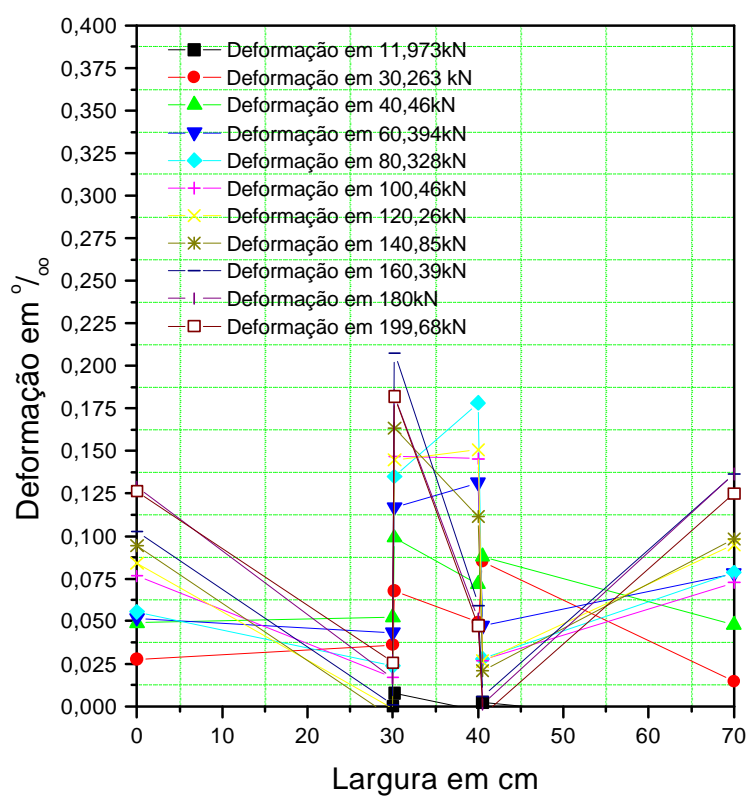

FIGURA 6.25 - DEFORMAÇÕES AO LONGO DA LARGURA - SUPERFÍCIE INFERIOR DA MESA

A fig.6.26 mostra a variação das deformações ao longo da altura da viga VT 02, no decorrer do ensaio. Para cada força aplicada, tomou-se a média das deformações para os pontos de igual altura, construindo-se assim o gráfico. Foram medidas deformações na parte superior e na inferior da mesa e na armadura 
tracionada. Nota-se nesse gráfico uma variação praticamente linear das deformações, validando as hipóteses feitas inicialmente.

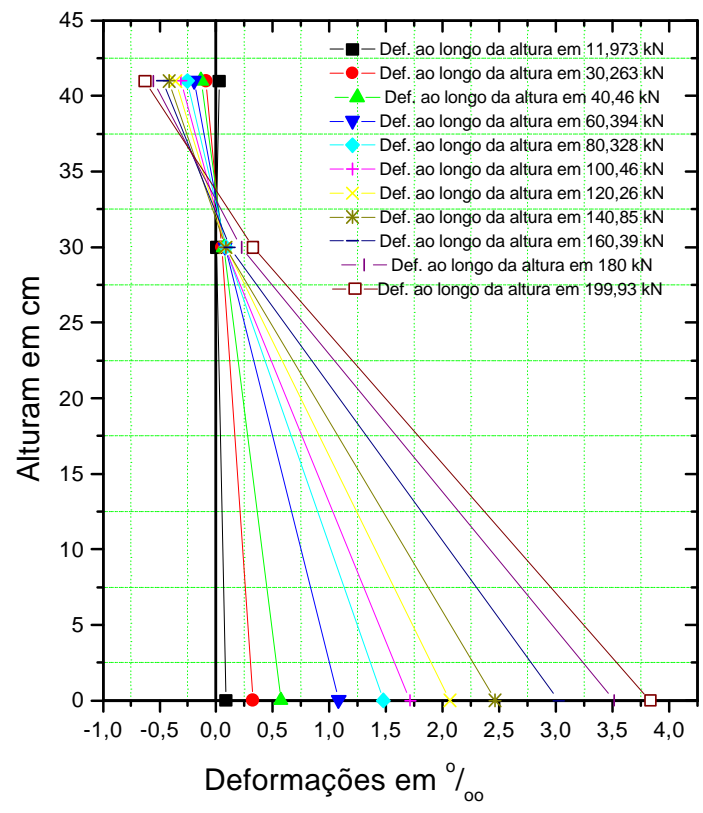

FIGURA 6.26 - DEFORMAÇÃO AO LONGO DA ALTURA DA VIGA

Na fig.6.26 observa-se que, à medida que o carregamento aumenta, a linha neutra sobe, provocando o escoamento do aço até o limite de $10 \%$. Isto caracteriza uma ruína da peça no domínio 2, para o qual a peça foi previamente dimensionada.

Para a carga última do ensaio, o momento correspondente foi de $\mathrm{M}_{\text {últ,exp }}=110 \mathrm{kNm}$. O valor do momento último resistente esperado era de, $\mathrm{M}_{\text {últ,teo }}=80 \mathrm{kNm}, 27 \%$ menor que o valor obtido experimentalmente. A diferença está a favor da segurança.

Com base nas discussões feitas nos parágrafos anteriores, e principalmente nos resultados apresentados no último, pode-se dizer que o dimensionamento à flexão do modelo da viga VT 02 pode ser feito utilizando as mesmas hipóteses do concreto armado, segundo a NBR 6118. 


\subsubsection{Deslocamentos}

Em função das condições de apoio e do tipo de carregamento, os deslocamentos são calculados a partir da equação da linha elástica, relativa à teoria de flexão. Para uma viga biapoiada com forças F/2 aplicadas nos terços do vão, o deslocamento máximo é dado pela expressão:

$$
\delta=\frac{23 \mathrm{FL}^{3}}{1296 \mathrm{EI}_{\mathrm{e}}}
$$

onde:

$\mathrm{L}$ = vão teórico;

$\mathrm{E}=$ módulo de elasticidade do material.

$\mathrm{O}$ cálculo dos deslocamentos para a viga $\mathrm{T}$ equivalente foi feito primeiramente para a seção não fissurada (estádio I). Para o momento atuante maior que o de fissuração, o cálculo dos deslocamentos foi feito utilizando o momento de inércia efetivo $\left(I_{e}\right)$, situado entre o do estádio I e do estádio II, pois a peça apresenta regiões fissuradas intercaladas por regiões não fissuradas, configurando assim uma situação intermediária entre os dois estádios. O momento de inércia efetivo foi obtido através da eq.(5.8) (Fórmula de Branson), fornecida pelo ACI:

$$
I_{e}=\left(\frac{M_{r}}{M}\right)^{3} I_{1}+\left[1-\left(\frac{M_{r}}{M}\right)^{3}\right] I_{2}<I_{1},
$$

onde:

$M_{r}$ : momento de fissuração;

$M$ : momento aplicado;

$I_{1}$ : momento de inércia referente ao estádio I;

$I_{2}:$ momento de inércia referente ao estádio II.

$\mathrm{O}$ momento de inércia $\mathrm{I}_{\mathrm{e}}$ varia para cada valor do carregamento maior que o de fissuração, construindo-se assim a curva teórica dos deslocamentos, mostrada na 
fig.6.27, onde se considera essa perda de rigidez, ao longo do ensaio, após a abertura da primeira fissura.

A fig.6.27 mostra a comparação entre os valores teóricos dos deslocamentos e os experimentais.

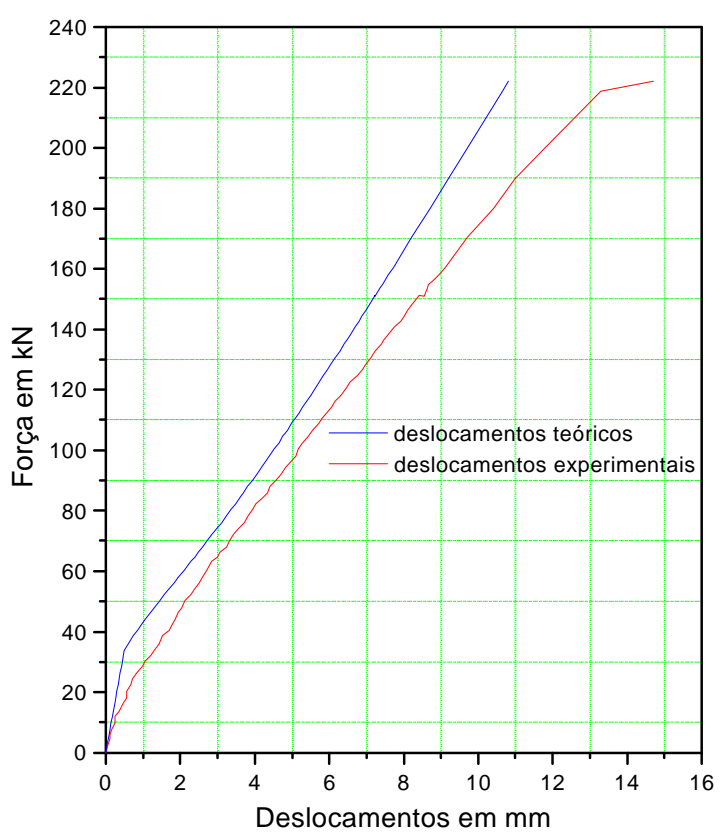

FIGURA 6.27 - COMPARAÇÃO ENTRE OS DESLOCAMENTOS TEÓRICOS E OS EXPERIMENTAIS

Os deslocamentos teóricos resultaram em torno de $14 \%$ menores que os experimentais. Ainda assim, considera-se uma boa estimativa o cálculo dos deslocamentos da maneira que foi realizada. A diferença entre os valores teóricos e os experimentais pode ser atribuída principalmente ao valor do módulo de elasticidade E, utilizado nos cálculos, determinado experimentalmente através do ensaio de compressão de corpos-de-prova cilíndricos de $10 \mathrm{~cm}$ x $20 \mathrm{~cm}$. Pelo modo de execução da viga, por meio de projeção da argamassa, o módulo E da argamassa da viga é menor que o determinado nos ensaios dos corpos-de-prova.

\subsubsection{Força cortante}

As deformações nos estribos foram registradas em quatro extensômetros, colados em dois estribos localizados a $50 \mathrm{~cm}$ de cada apoio. Com o sistema de aquisição de dados acoplado aos extensômetros, pôde-se construir o gráfico da 
fig.6.28. Os canais 16 e 17, conforme esquema apresentado na fig.6.20, estão conectados aos extensômetros do estribo da esquerda, e os canais 18 e 19, no estribo da direita.

No trecho central da viga ocorre flexão pura. As primeiras fissuras surgem nessa região e são praticamente verticais (fig.6.22). As fissuras de cisalhamentos são inclinadas e ocorrem nas regiões próximas aos apoios, onde atuam forças cortantes (fig.6.21).

Até a carga correspondente à primeira fissura de cisalhamento (aproximadamente $50 \mathrm{kN}$ ), as tensões na armadura transversal são desprezíveis, evidenciando-se que os estribos só são solicitados efetivamente a partir desse nível de carregamento, como pode ser observado na fig 6.28.

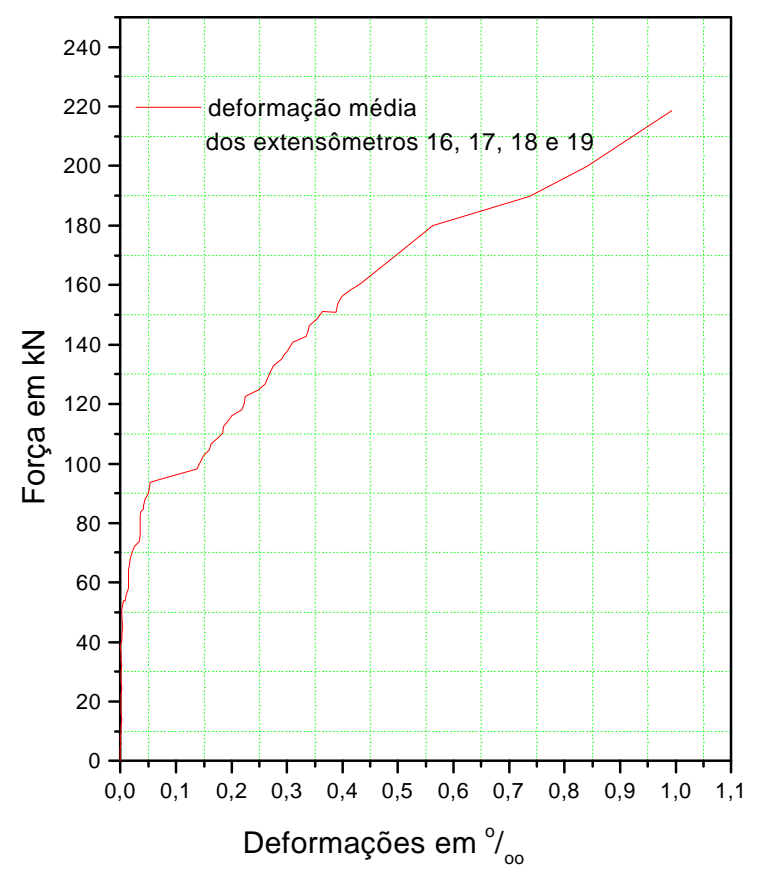

FIGURA 6.28 - GRÁFICO FORÇA X DEFORMAÇÃO PARA OS ESTRIBOS 


\subsection{CONCLUSÕES PARCIAIS}

O valor da resistência da argamassa à tração, utilizado para determinar o momento de fissuração, foi o principal responsável pela diferença encontrada entre os valores teórico e experimental, para a viga VT 02. O valor fornecido pela expressão da NBR 6118 (1982) é maior que o determinado no ensaio de compressão axial. Desde que se tenha o valor real da resistência da argamassa à tração, o modelo utilizado fornece resultados satisfatórios.

A viga $\mathrm{T}$ sanduíche foi dimensionada utilizando as hipóteses usuais do cálculo de concreto armado. O elemento foi dimensionado no domínio 2, no qual o aço se encontra com deformação de $10 \%$ e o concreto permanece com níveis de deformações menores que $3,5 \%$, não se utilizando, portanto, sua capacidade resistente total.

Verificando-se as deformações no modelo, tanto na tração como na compressão, observa-se que esse tipo de estrutura mista (viga $\mathrm{T}$ composta por elementos sanduíche com núcleo de EPS) se comporta, em relação à flexão, de maneira semelhante à de uma peça maciça de concreto armado usual.

A modificação realizada no segundo modelo, preenchendo-se com argamassa a interseção dos elementos sanduíche, melhorou sobremaneira a ligação entre as partes. Essa ligação monolítica entre as nervuras laterais garantiu um comportamento da peça à flexão, sem uma influência significativa das deformações relativas das nervuras transversais.

Houve uma pequena diferença entre os valores teóricos e experimentais dos deslocamentos, para a viga VT 02. O valor do módulo de deformação longitudinal foi o principal responsável por essa diferença, visto que o valor utilizado no cálculo foi determinado a partir do ensaio de compressão de corpos-de-prova cilíndricos, que não corresponde ao mesmo valor da argamassa projetada.

De uma maneira geral, o comportamento do modelo à flexão aproxima-se bastante do relativo a uma peça de seção equivalente de concreto armado, podendose utilizar as mesmas hipóteses da NBR 6118 (1982), desde que se utilizem os valores reais das propriedades da argamassa projetada. 


\section{ANÁLISE EXPERIMENTAL DE PAINÉIS À FLEXÃO}

Foi programada uma série de ensaios à flexão, variando-se a distribuição das nervuras e verificando-se sua influência no comportamento estrutural do painel. São descritos a seguir: tipos de modelos estudados, materiais empregados, instrumentação e respectivos esquemas estruturais dos modelos.

\subsection{DESCRIÇÃO DOS MODELOS EXPERIMENTAIS}

Neste item apresentam-se a quantidade de modelos ensaiados, suas dimensões e os tipos dos modelos, levando-se em conta a posição das nervuras e a existência ou não de armadura de cisalhamento.

\subsubsection{Quantidade dos modelos}

Foram confeccionados oito modelos para esse ensaio. Os painéis foram designados por PSF, contendo os índices I, II, ..., IIa, IVa, em função do tipo de configuração da nervura.

\subsubsection{Dimensões}

A fig.7.1 mostra as configurações básicas dos painéis ensaiados, bem como suas dimensões.

Os tipos de configuração mostrados na fig.7.1 são: a) painel sem nervuras; b) painel com nervuras longitudinais; c) painel com nervuras transversais nas extremidades; d) painel com nervuras nas extremidades transversais e longitudinais; e) painel com nervuras nas extremidades transversais e longitudinais e uma nervura longitudinal no meio do painel.

Foi adotada uma espessura de $3 \mathrm{~cm}$ para as placas e para as nervuras. $\mathrm{O}$ núcleo, descrito mais adiante, é igual para todos os modelos, sendo composto por uma placa de EPS com 7,8cm de espessura. 


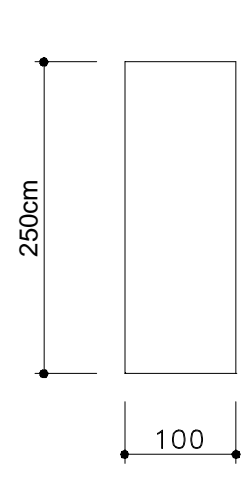

a)

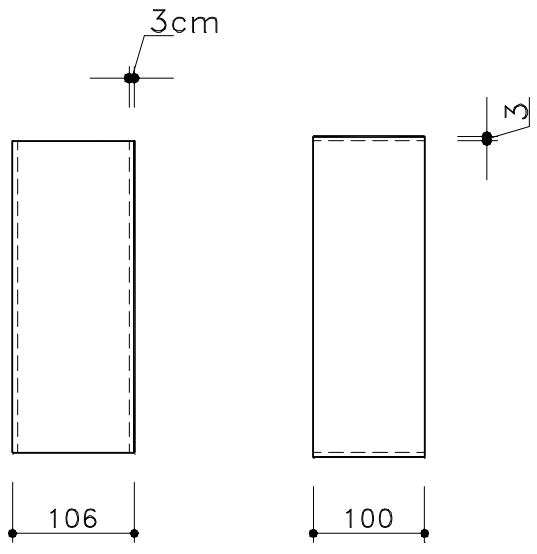

b)

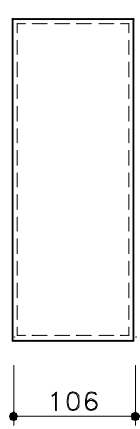

d)

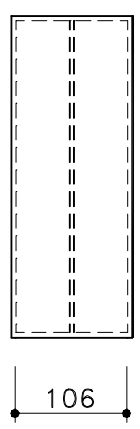

e)

FIGURA 7.1 - DIMENSÕES DOS PAINÉIS E CONFIGURAÇÕES DAS NERVURAS

\subsubsection{Tipos}

A tabela 7.1 mostra um resumo dos tipos e das quantidades dos modelos confeccionados. Os modelos ensaiados à flexão foram denominados PSF, podendo ser do tipo I, II, III, IV, V, II $\boldsymbol{a}$, IV $\boldsymbol{a}$ e Va. O índice $\boldsymbol{a}$ refere-se à inexistência de armadura de cisalhamento, no interior das nervuras.

TABELA 7.1 -Tipos dos modelos ensaiados

\begin{tabular}{|l|c|c|}
\hline \multicolumn{1}{|c|}{ CONFIGURAÇÃo } & \multicolumn{2}{c|}{$\begin{array}{r}\text { ENSAIO À FLEXÃo } \\
\text { TIPOS DOS MODELOS }\end{array}$} \\
\hline Sem nervuras & PSF-I & - \\
\hline Com nervuras longitudinais & PSF-II & PSF-IIa \\
\hline Com nervuras transversais & PSF-III & - \\
\hline $\begin{array}{l}\text { Com nervuras em todas as } \\
\text { extremidades }\end{array}$ & PSF-IV & PSF-IVa \\
\hline $\begin{array}{l}\text { Com nervuras nas extremidades } \\
\text { e uma longitudinal no centro }\end{array}$ & PSF-V & PSF-Va \\
\hline Quantidade de modelos & 5 & 3 \\
\hline
\end{tabular}

\subsection{MATERIAIS EMPREGADOS}

Apresentam-se a seguir as características da argamassa, do EPS e da armadura. 


\subsubsection{Argamassa}

O traço da argamassa foi o obtido experimentalmente, conforme descrito no ANEXO A. A proporção adotada forneceu uma argamassa projetável, tanto manualmente como através da caneca de projeção. Foi empregado cimento Portland de alta resistência inicial - CPV-ARI PLUS, marca Ciminas. Utilizaram-se superplastificante marca Reax 3000 e sílica ativa marca Silmix.

A relação obtida cimento/areia foi de 1:3, com adição de $2 \%$ de superplastificante (SP) e $10 \%$ de sílica ativa (SA). O fator água-cimento foi $\mathrm{a} / \mathrm{c}=0,51$. As porcentagens são tomadas em função do peso do cimento. A utilização da sílica ativa melhorou alguma característica da argamassa, tais como: coesão, resistência e compacidade.

Como agregado miúdo utilizou-se areia natural, enquadrada como areia média, dentro dos limites granulométricos conforme a NBR 7211. Foram feitos os ensaios de caracterização da areia, obtendo-se para massa específica real um valor de $2,62 \mathrm{~g} / \mathrm{cm}^{3}$ e para a massa unitária o valor de 1,51 .

A argamassa tinha consistência, trabalhabilidade e fluidez para permitir sua projeção na superfície do núcleo, por meio da caneca de projeção. Foram determinados para cada etapa de projeção os Índices de Consistência (I.C.), e foram moldados corpos-de-prova cilíndricos de $10 \mathrm{~cm}$ x $20 \mathrm{~cm}$, para a determinação da resistência à compressão no dia do ensaio do painel $\left(f_{c j}\right)$, da resistência à tração $\left(f_{i j}\right) e$ do módulo de elasticidade (E). Esses dados são apresentados na tab. 7.2.

TABELA 7.2 - Controle da argamassa utilizada na confecção dos modelos

\begin{tabular}{|l|c|c|c|c|}
\hline Modelos & $\mathbf{f}_{\mathbf{t j}}(\mathbf{M P a})$ & $\mathbf{f}_{\mathbf{c j}}(\mathbf{M P a})$ & $\mathbf{E}(\mathbf{M P a})$ & $\mathbf{I . C} .(\mathbf{m m})$ \\
\hline PSF I & 2,82 & 65,83 & 22.846 & 240 \\
\hline PSF II & 2,88 & 67,67 & 28.120 & 229 \\
\hline PSF IIa & 2,48 & 57,53 & 28.982 & 225 \\
\hline PSF III & 2,49 & 69,25 & 28.042 & 225 \\
\hline PSF IV & 2,75 & 66,10 & 28.283 & 233 \\
\hline PSF IVa & 2,44 & 55,80 & 29.103 & 234 \\
\hline PSF V & 2,70 & 71,03 & 29.975 & 228 \\
\hline PSF Va & 2,77 & 66,34 & 29.339 & 216 \\
\hline
\end{tabular}




\subsubsection{Núcleo}

Foram utilizadas placas de EPS como material do núcleo. As placas foram fornecidas pela empresa Código Engenharia, que produz pré-painéis (placas de EPS com telas soldadas, dispostas em ambos os lados, ligadas por fios que atravessam a placa de EPS, fig.7.2), para a construção de edificações através da técnica sanduíche. As placas de EPS empregadas nos pré-painéis possuíam 2,5m de comprimento por 1,0 m de largura, com 7,8cm de espessura (fig7.3). Para todos os modelos, as dimensões dos pré-painéis são as mesmas.

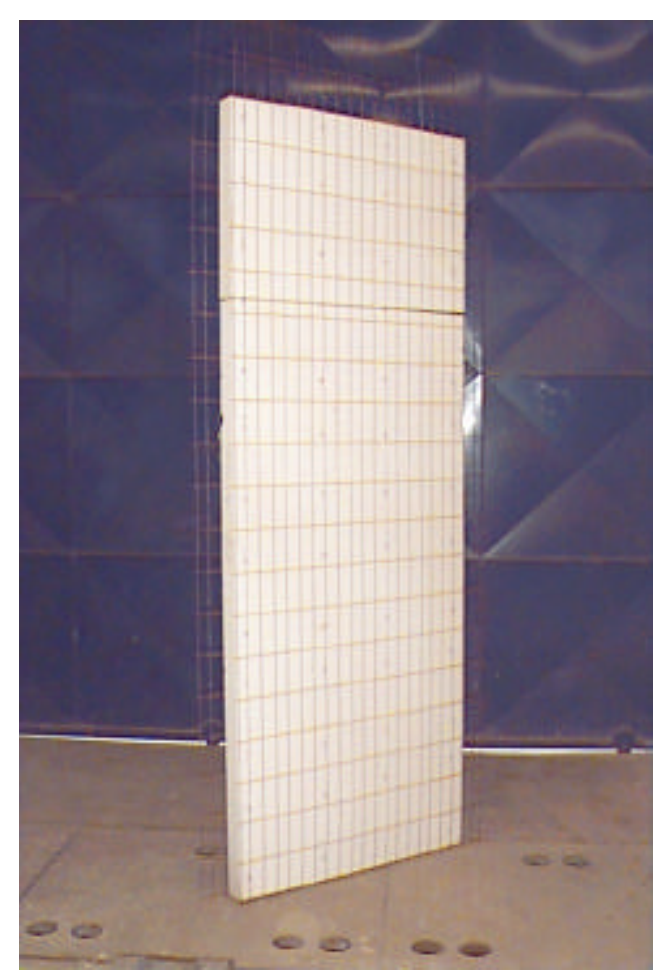

FIGURA 7.2 - PRÉ-PAINEL (NÚCLEO DE EPS + TELA SOLDADA)

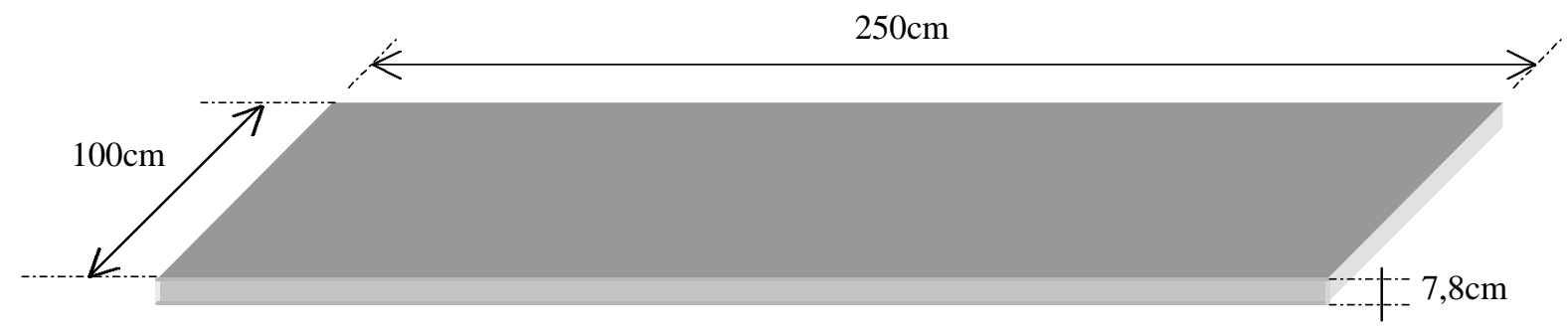

FIGURA 7.3 - DIMENSÕES DA PLACA DE EPS (NÚCLEO) 


\subsubsection{Armadura: tipo e disposição}

A armadura era composta por duas telas soldadas e por barras de reforço, como parte do pré-painel (placa de EPS mais tela soldada). Foram dispostas nos dois lados da placa de EPS e ligadas entre si por fios, do mesmo diâmetro dos fios da tela, conforme a fig.7.4. Esses fios, ligados à tela por meio de solda, atravessavam a placa de EPS, fazendo um ângulo de aproximadamente $45^{\circ}$ com a superfície da placa. A função principal desses fios, ou conectores, é manter as telas a uma distância de $1 \mathrm{~cm}$ da face da placa de EPS, dos dois lados, e fazer com que o pré-painel possua rigidez suficiente para permitir a projeção da argamassa.
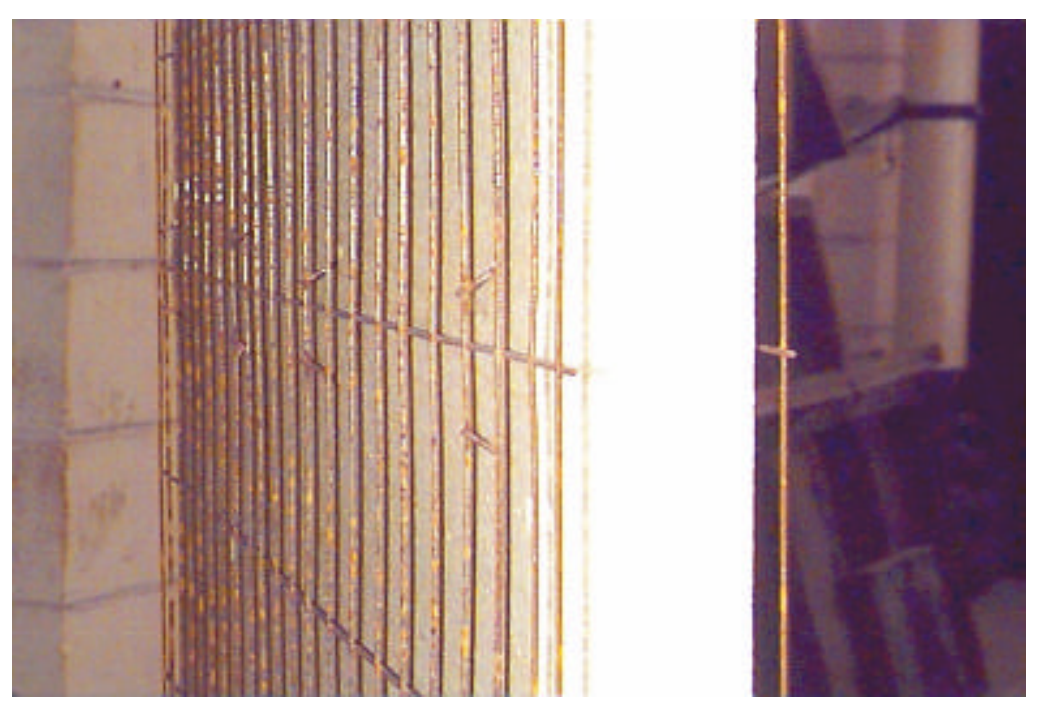

FIGURA 7.4 - DETALHE DO PRÉ-PAINEL (EPS + TELA SOLDADA)

O aço empregado na tela e nos conectores foi o CA-60, com diâmetro igual a $2,4 \mathrm{~mm}$. Os fios longitudinais possuíam um espaçamento de $15 \mathrm{~cm}$ e os transversais, de $5 \mathrm{~cm}$, como mostra a fig.7.5.

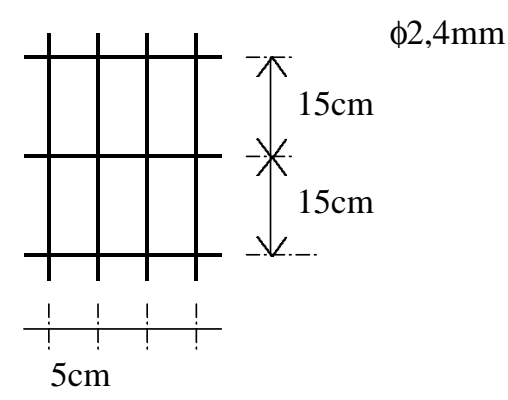

FIGURA 7.5 - ESPAÇAMENTOS DA TELA SOLDADA 
Os fios complementares de aço CA-50 tinham diâmetro de 4,2mm. Em cada lado do pré-painel eram colocados quatro fios distribuídos no sentido transversal.

Os modelos PSF-II, PSF-III, PSFIV e PSF-V possuíam nervuras nas extremidades. Essas nervuras eram armadas com fios de $4,2 \mathrm{~mm}$ a cada $15 \mathrm{~cm}$, de acordo com a fig.7.6.

Esses "estribos" eram amarrados nas telas soldadas com arame $\mathrm{n}^{\mathrm{0}} 18$. Os demais modelos que continham nervuras (PSF-IIa, PSF-IIIa, PSF-IVa e PSF-Va) não possuíam estribos.

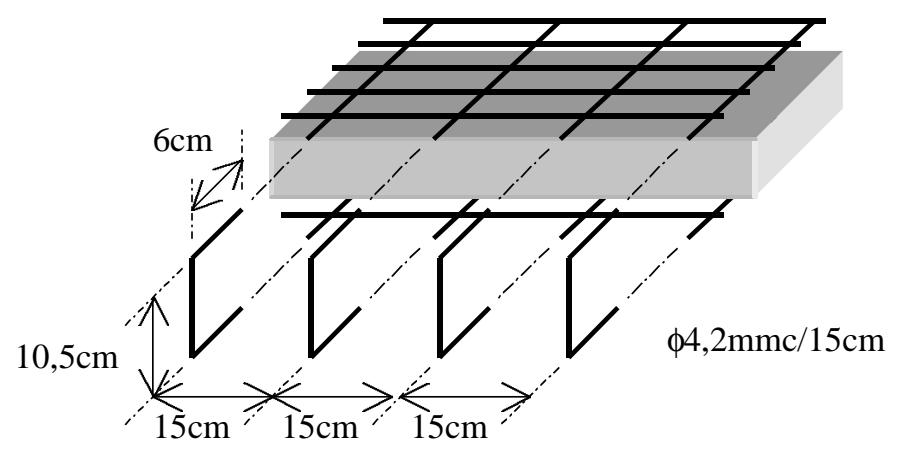

FIGURA 7.6 - ARMADURA DE CISALHAMENTO DAS NERVURAS (DETALHE DE UM PEDAÇO DO PRÉ-PAINEL)

\subsection{CONFECÇÃO DOS MODELOS}

Após a execução da armadura (complementar e das nervuras) e sua instrumentação, os pré-painéis foram posicionados na posição vertical e preparados para aplicação da argamassa projetada (fig.7.7). Foram colocados ganchos na parte superior dos painéis, para transporte dos elementos depois de prontos. 

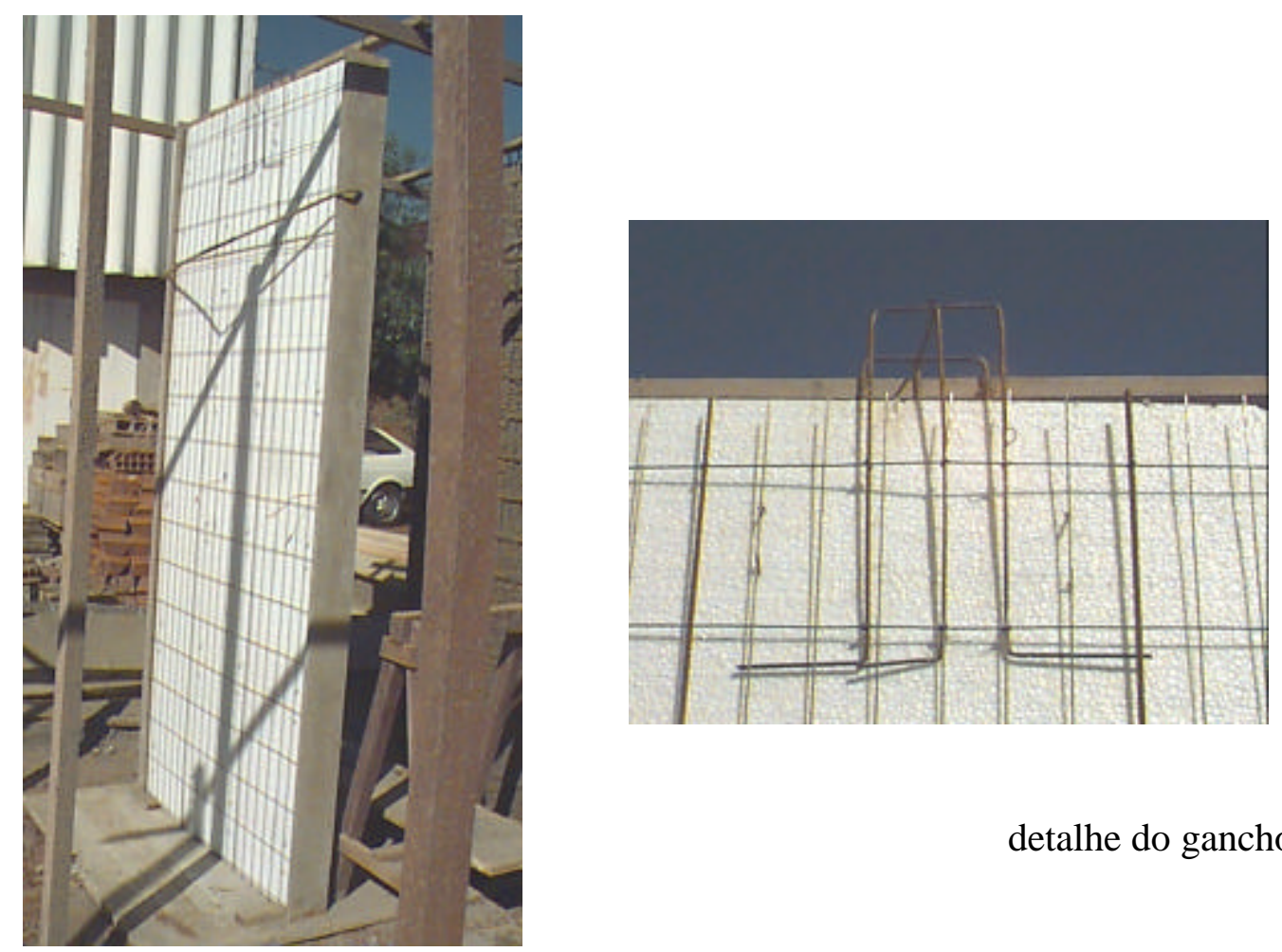

detalhe do gancho

FIGURA 7.7 - PAINÉIS POSICIONADOS PARA PROJEÇÃO DA ARGAMASSA

A argamassa foi projetada nos painéis em duas etapas, utilizando-se uma caneca de projeção, acionada por um compressor de ar, com capacidade de vazão de 710 litros/min e pressão do ar de $120 \mathrm{lb} / \mathrm{in}^{2}$. A primeira etapa era feita de modo a deixar a armadura aparente. $\mathrm{O}$ excesso era retirado por meio de uma régua, mantendo-se uma espessura média de $1,0 \mathrm{~cm}$. Nessa etapa eram projetados os dois lados e, conforme o caso, as nervuras laterais (fig.7.8).

$\mathrm{Na}$ segunda etapa de projeção da argamassa, realizou-se o cobrimento da armadura $(1,5 \mathrm{~cm})$ e o acabamento da superfície. A espessura final das placas, de cada lado, era de $3,0 \mathrm{~cm}$. Nessa etapa eram colocados sarrafos nas laterais do painel, que serviam como guias, para garantir a espessura de $14 \mathrm{~cm}$ ao longo de todo o painel (fig.7.9). 

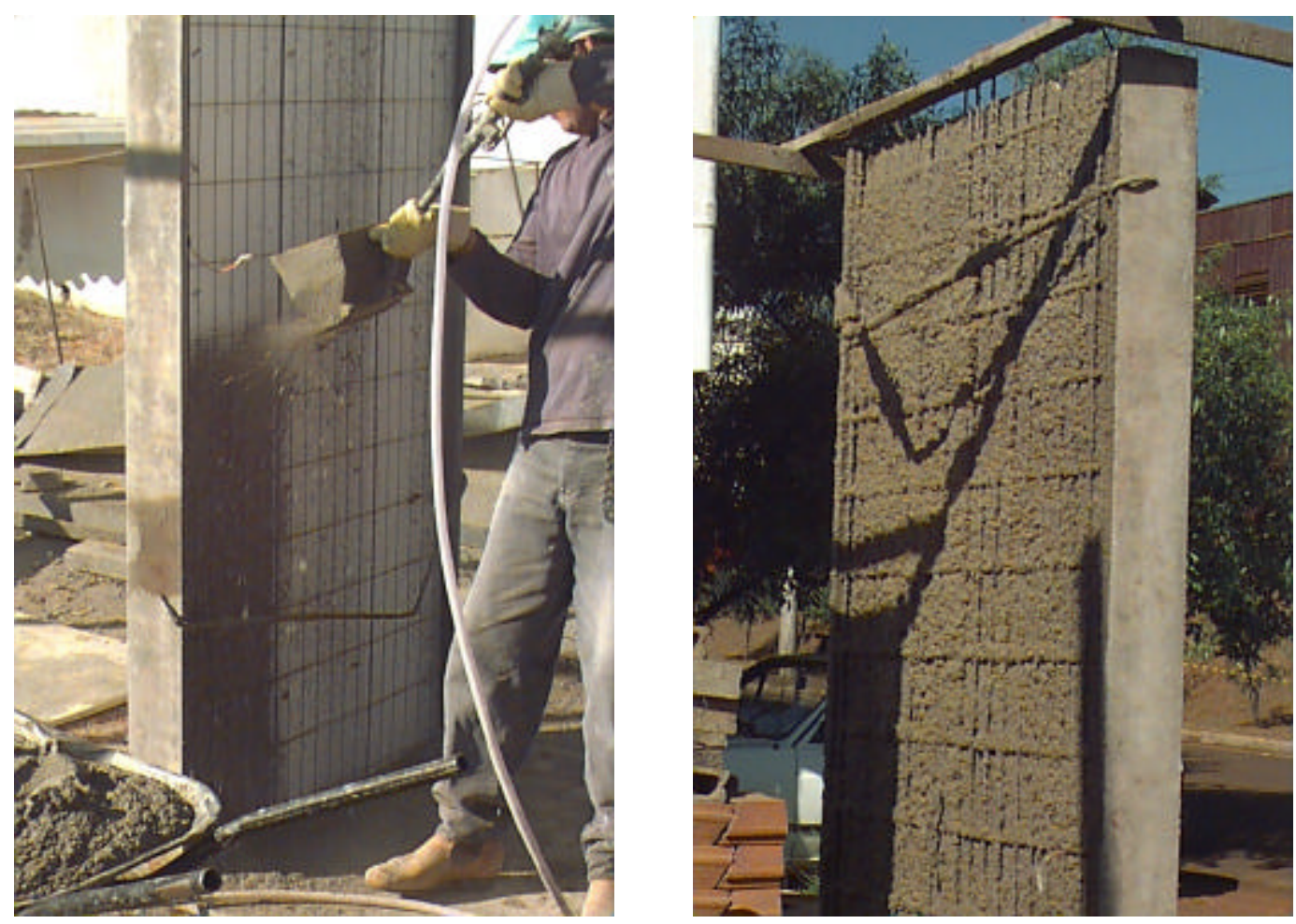

FIGURA 7.8 - PRIMEIRA ETAPA DA PROJEÇÃO DA ARGAMASSA

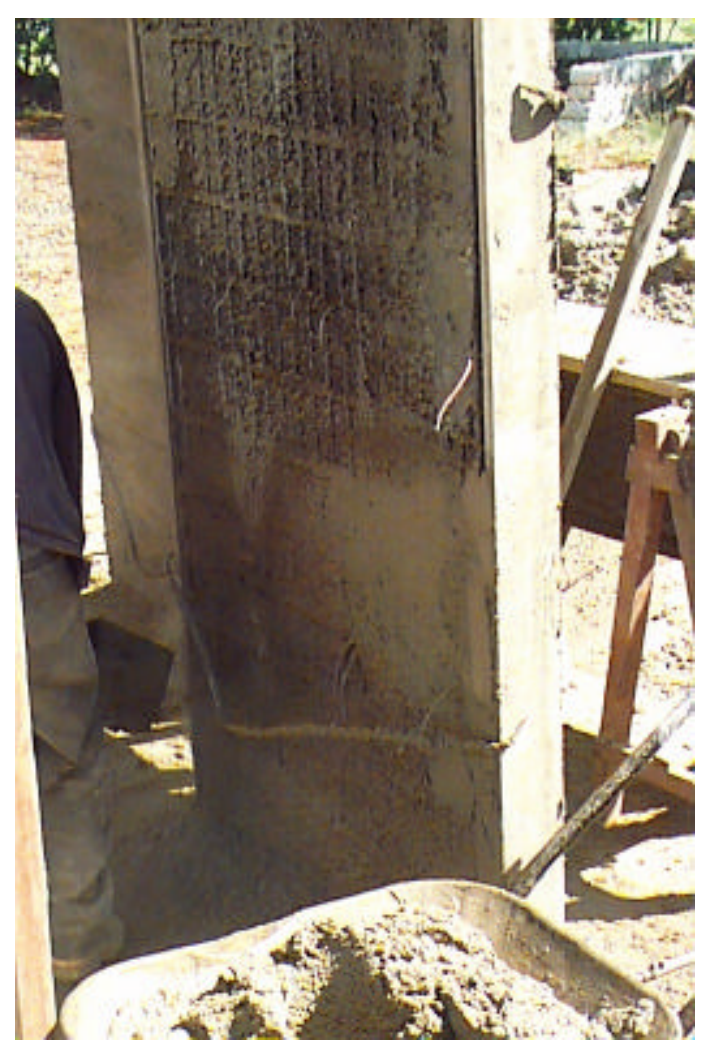

FIGURA 7.9 - SEGUNDA ETAPA DA PROJEÇÃO DA ARGAMASSA. SARRAFOS NAS LATERAIS 
$\mathrm{O}$ acabamento do painel era feito da mesma maneira que em emboço de argamassa, por meio de uma desempenadeira de madeira. Após o acabamento, o painel era envolvido por um plástico, para favorecer a cura da peça. Além do plástico, a peça era umedecida, jogando-se água através de uma mangueira.

O controle da argamassa foi feito moldando-se, para cada etapa de projeção da argamassa de cada painel, nove corpos-de-prova cilíndricos de $10 \mathrm{~cm}$ de diâmetro por $20 \mathrm{~cm}$ de altura, sendo:

- Três corpos-de-prova para resistência à compressão aos sete dias;

- Três corpos-de-prova para resistência à tração, no dia do ensaio do painel;

- Três corpos-de-prova para resistência à compressão, no dia do ensaio do painel, sendo que dois destes foram utilizados para determinação do módulo de elasticidade longitudinal.

O resumo dos resultados do controle tecnológico do concreto foram apresentados na tabela 7.2.

\subsection{ESQUEMA ESTRUTURAL E INSTRUMENTAÇÃO}

Foi adotada como esquema estrutural uma viga simplesmente apoiada, submetida a um carregamento nos terços do vão. A força foi aplicada utilizando-se um atuador servo-hidráulico de marca INSTRON, com capacidade de 500kN. O ensaio foi realizado com controle de deslocamento, aplicando-se uma velocidade de $0,04 \mathrm{~mm} / \mathrm{s}$. Os esquemas estático e de carregamento são mostrados na fig.7.10. As figuras 7.11 e 7.12 mostram o aparato para a aplicação do carregamento e o pórtico de reação.

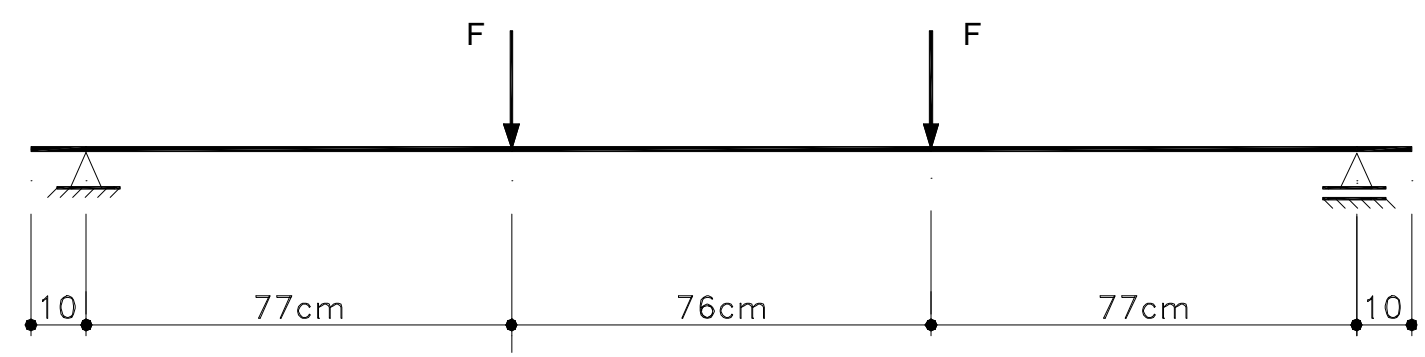

FIGURA 7.10 - ESQUEMA ESTÁTICO E DE CARREGAMENTO 


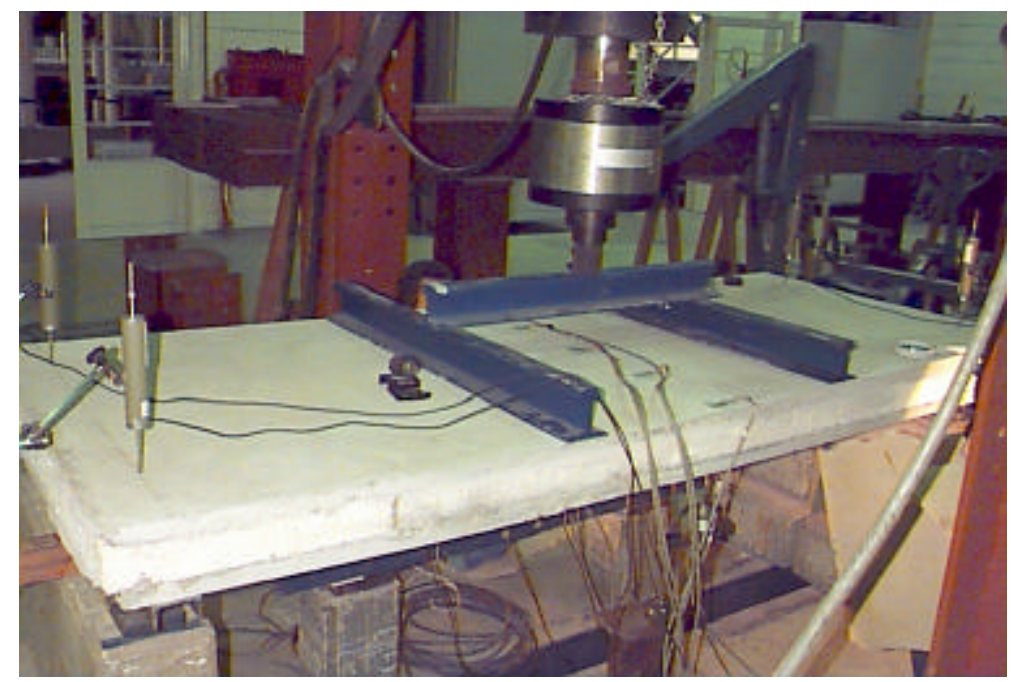

FIGURA 7.11 - APARATO PARA O CARREGAMENTO NOS TERÇOS DO VÃO DO PAINEL

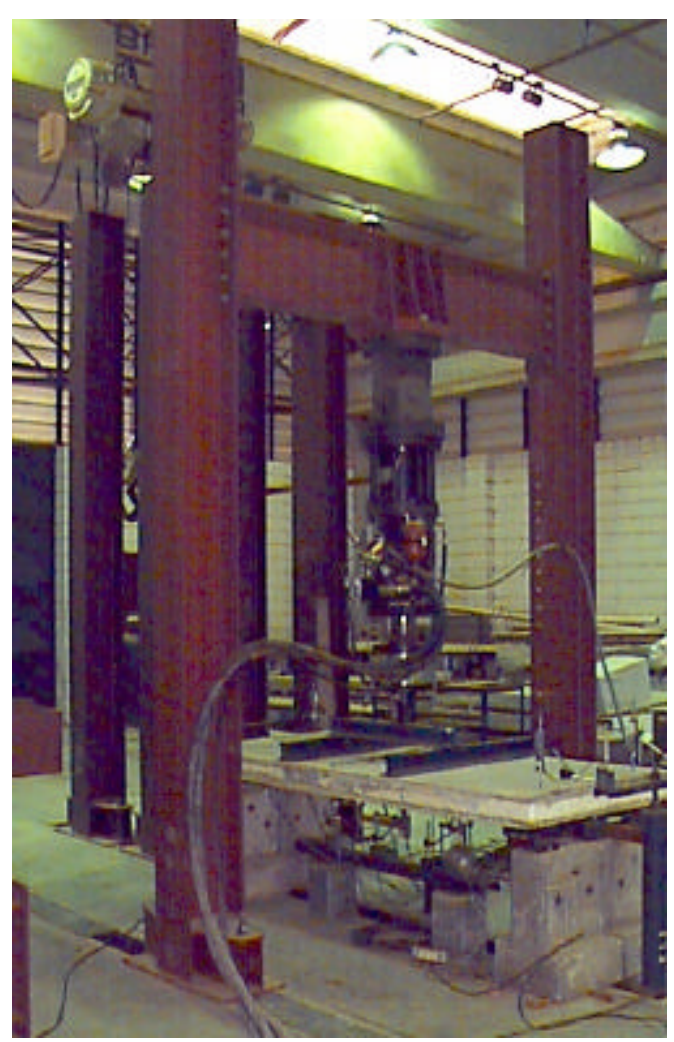

FIGURA 7.12 - PÓRTICO DE REAÇÃO UTILIZADO NOS ENSAIO DE FLEXÃO DOS PAINÉIS

Os deslocamentos verticais foram medidos em nove pontos, conforme mostra a fig.7.13, através de transdutores elétricos da marca Kyowa, modelo DT 100 A, com sensibilidade de $0,05 \mathrm{~mm}$ e curso de $100 \mathrm{~mm}$. Também foram medidos os deslocamentos relativos entre as duas placas dos painéis tipo sanduíche. Para isto 
colocaram-se transdutores na posição horizontal, localizados nas extremidades do painel.
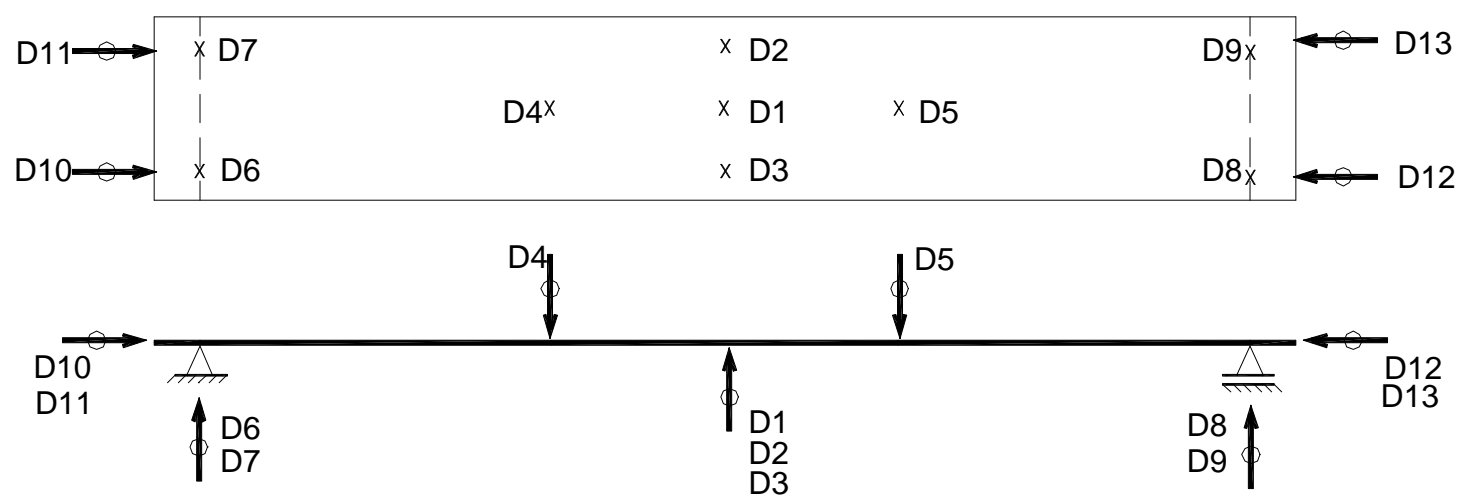

FIGURA 7.13 - POSIÇÃO DOS TRANSDUTORES ELÉTRICOS AO LONGO DO PAINEL

Foram medidas as deformações na parte central da placa comprimida, através de extensômetros colados em sua superfície. Os extensômetros, marca Kyowa, modelo KGF-10-C1-11, tinham base de 10mm. Suas disposições estão mostradas na fig.7.14.

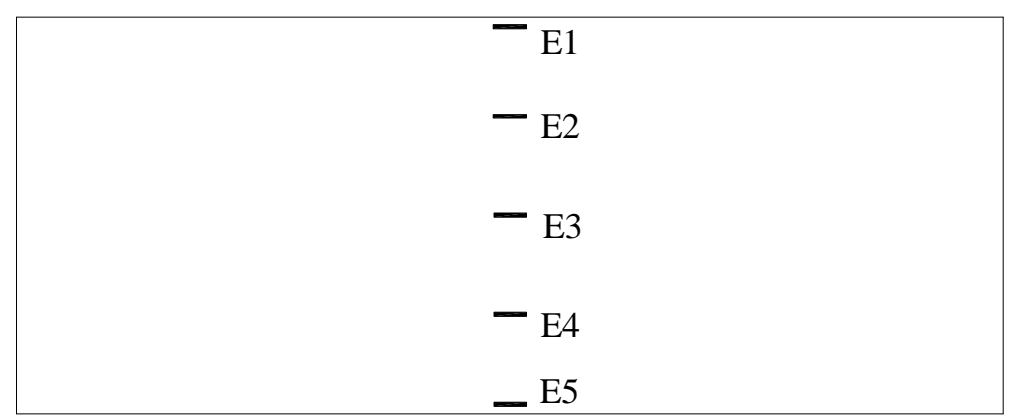

FIGURA 7.14 - DISPOSIÇÃO DOS EXTENSÔMETROS NA PLACA COMPRIMIDA

$\mathrm{Na}$ armadura da placa tracionada foram colados cinco extensômetros, para medição das deformações decorrentes da tração. Eles foram colados tanto na tela soldada como na armadura complementar. A disposição desses extensômetros variaram de acordo com o tipo do modelo a ser ensaiado, como é mostrado na fig.7.15. 
PSF-I, PSF-II, PSF-IIa, PSF-III, PSF-IV, PSF-IVa

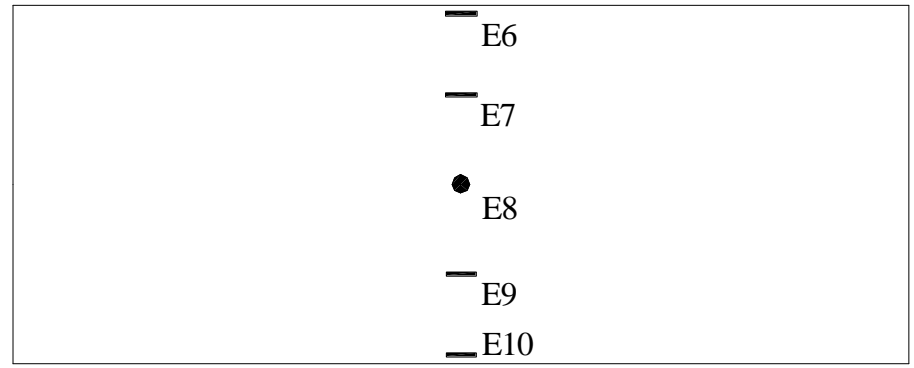

- extensômetro colado na tela soldada

I extensômetro colado na armadura complementar

PSF-V, PSF-Va

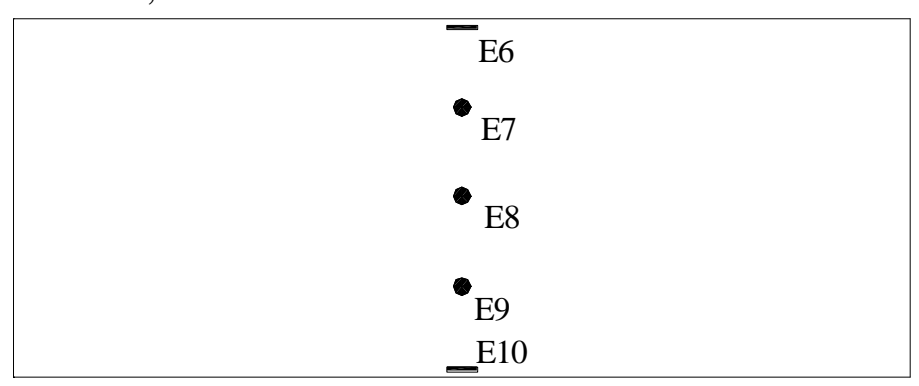

FIGURA 7.15 - DISPOSIÇÃO DOS EXTENSÔMETROS DA ARMADURA DE TRAÇÃO

Os conectores de ligação das telas soldadas dos pré-painéis também foram instrumentados, colando-se extensômetros em sua superfície para a medição das deformações, com o objetivo de avaliar a contribuição desses conectores na composição do painel tipo sanduíche. Foram colados extensômetros em quatro conectores por painel, dispostos conforme mostra a fig.7.16.

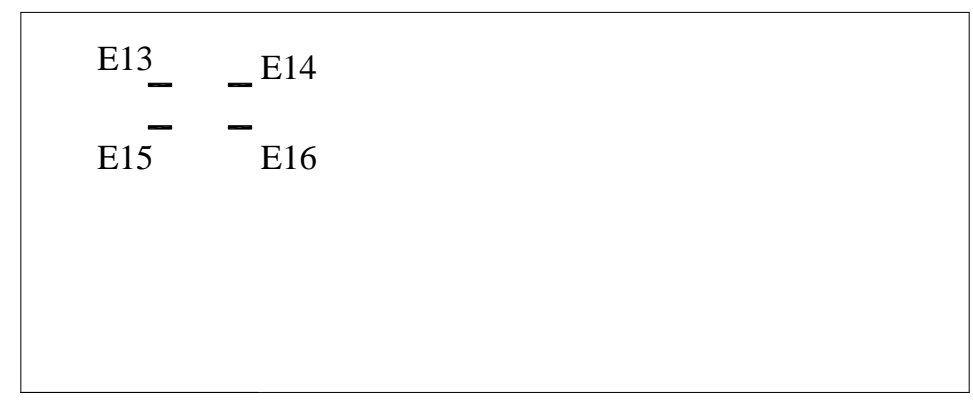

FIGURA 7.16 - DISPOSIÇÃO DOS EXTENSÔMETROS COLADOS NOS CONECTORES DE LIGAÇÃO DAS TELAS SOLDADAS DOS PRÉ-PAINÉIS 
Para os modelos PSF II, PSF IV e PSF V foram colados extensômetros na armadura das nervuras para o acompanhamento das deformações, conforme mostram as figuras 7.17 (a) e 7.17 (b).

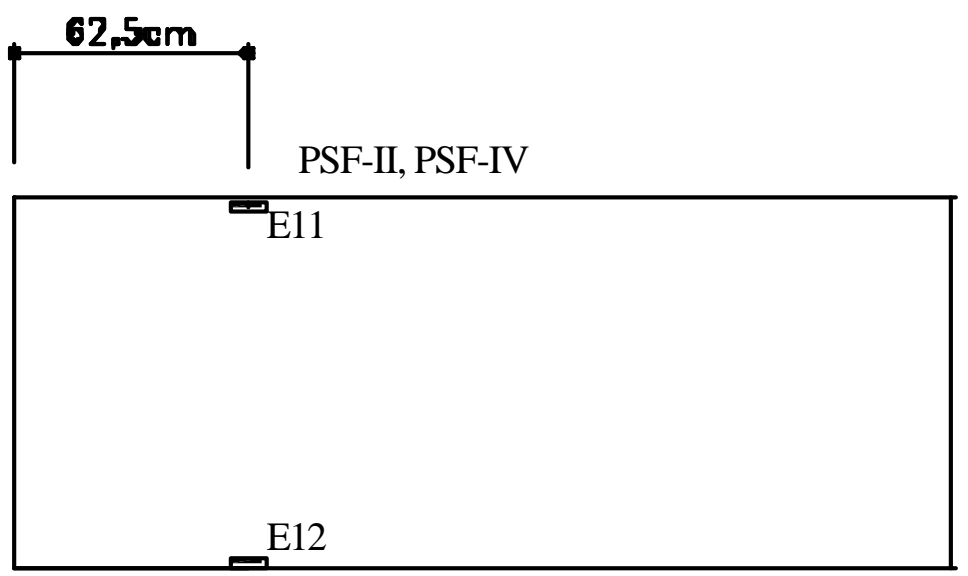

FIGURA 7.17(a) - DISPOSIÇÃO DOS EXTENSÔMETROS COLADOS NA ARMADURA DAS NERVURAS

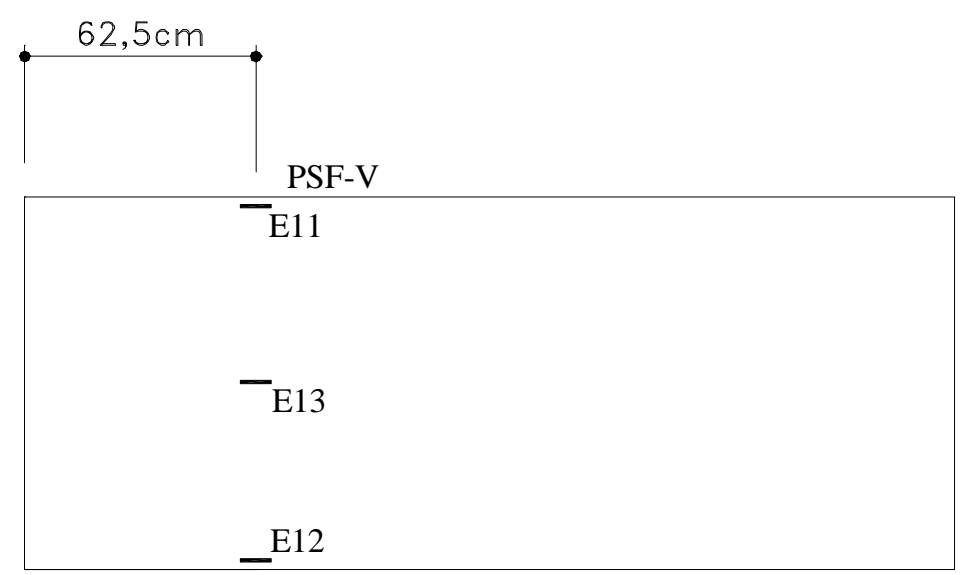

FIGURA 7.17(b) - DISPOSIÇÃO DOS EXTENSÔMETROS COLADOS NA ARMADURA DAS NERVURAS

Foi utilizado um sistema de aquisição de dados, marca Measurements Group, modelo System 5000, para registrar as leituras indicadas pela célula de carga, pelos transdutores elétricos e pelos extensômetros. 


\subsection{RESULTADOS OBTIDOS E ANÁLISE DOS RESULTADOS}

Os painéis foram ensaiados à flexão, aplicando-se o carregamento nos terços do vão ao longo da largura. Para cada modelo obteve-se um valor do momento de fissuração e da carga de ruptura. Verificou-se para a maioria dos modelos ensaiados uma ruptura caracterizada por deformação excessiva do painel, observando-se também uma abertura excessiva das fissuras.

\subsubsection{Momento de fissuração}

O momento de fissuração $\left(M_{r}\right)$, segundo o anexo da NBR 7197 (1989), é calculado pela eq.6.3 (pag.110).

No caso em estudo, a seção é do tipo sanduíche, e o grau de composição entre as faces é parcial. SHEPPARD \& PHILLIPS (1989), conforme comentado no capítulo 3, sugerem uma correção do momento de inércia, para levar em conta a perda de rigidez pela movimentação relativa entre as faces. A seção sanduíche é transformada em uma seção maciça de inércia equivalente. Seguindo essas recomendações, tem-se que:

$$
\mathrm{I}_{\text {corrigido }}=\mathrm{C} \cdot \mathrm{I} \text {, }
$$

onde:

$\mathrm{I}_{\text {corrigido }}=$ momento de inércia da seção equivalente;

$\mathrm{C}=$ coeficiente de correção;

I = momento de inércia da seção tipo sanduíche.

O momento de inércia I é calculado a partir da expressão 7.2.

$$
\mathrm{I}=\frac{\mathrm{b}}{12}\left(\mathrm{~h}^{3}-\mathrm{c}^{3}\right),
$$

onde:

b = largura da seção;

$\mathrm{h}=$ altura da seção;

$\mathrm{c}=$ espessura do núcleo. 
O momento de inércia $\mathrm{I}_{\text {corrigido }}$ pode ser escrito da seguinte maneira:

$$
I_{\text {corrigido }}=\frac{\mathrm{bh}_{\mathrm{eq}}^{3}}{12},
$$

onde $h_{\text {eq }}=$ altura da seção de inércia equivalente.

Comparando as expressões 7.1, 7.2 e 7.3, determina-se $h_{\text {eq }}$ em função de $C, h$ e c:

$$
\mathrm{h}_{\mathrm{eq}}=\sqrt[3]{\mathrm{C}\left(\mathrm{h}^{3}-\mathrm{c}^{3}\right)} \text {. }
$$

Adotando-se os valores da tabela 3.1 (pág.33), sugeridos por SHEPPARD \& PHILLIPS, $\mathrm{C}=0,22$ para os painéis sem nervuras e $\mathrm{C}=0,39$ para os painéis com nervuras, calculam-se a altura equivalente $h_{\text {eq }}$ e os valores da posição da linha neutra (x) e do momento de inércia (I), considerando-se estádio I. Substituindo-se os valores de $\mathrm{x}$, I e $\mathrm{h}_{\mathrm{eq}}$ na eq.6.3, determina-se o valor de $\mathrm{M}_{\mathrm{r} \text {,teórico }}$, para cada modelo.

A tabela 7.3 mostra os valores obtidos dos momentos fletores, referentes à primeira fissura ocorrida durante o ensaio de flexão, bem como os valores calculados teoricamente. A primeira fissura do painel representa uma mudança de inclinação da curva Força x Deslocamento. Os valores utilizados da resistência da argamassa à tração foram os obtidos dos ensaios relativos a cada modelo. $\mathrm{O}$ momento no meio do vão, produzido pelo peso próprio do modelo, foi somado ao valor de $\mathrm{M}_{\mathrm{r} \text {,exp. }}$.

TABELA 7.3 - Valores dos momentos de fissuração em kNm

\begin{tabular}{|l|c|c|c|c|c|}
\hline MODELO & $\mathbf{M}_{\mathbf{r}, \mathbf{e x p}}$ & $\mathbf{C}$ & $\mathbf{h}_{\text {eq }}(\mathbf{c m})$ & $\mathbf{M}_{\mathbf{r}, \text { teo }}$ & $\mathbf{M}_{\mathbf{r}, \mathbf{e x p}} / \mathbf{M}_{\mathbf{r} \text {,teo }}$ \\
\hline PSF I & 3,17 & 0,22 & 7,93 & 4,56 & $\mathbf{0 , 6 9}$ \\
\hline PSF II & 5,57 & 0,39 & 9,60 & 6,81 & $\mathbf{0 , 8 2}$ \\
\hline PSF IIa & 5,23 & 0,39 & 9,60 & 5,85 & $\mathbf{0 , 8 9}$ \\
\hline PSF III & 4,79 & 0,39 & 7,93 & 5,88 & $\mathbf{0 , 8 1}$ \\
\hline PSF IV & 4,71 & 0,39 & 9,60 & 6,49 & $\mathbf{0 , 7 3}$ \\
\hline PSF IVa & 3,57 & 0,39 & 9,60 & 5,76 & $\mathbf{0 , 6 2}$ \\
\hline PSF V & 5,31 & 0,39 & 9,60 & 6,37 & $\mathbf{0 , 8 3}$ \\
\hline PSF Va & 3,37 & 0,39 & 9,60 & 6,37 & $\mathbf{0 , 5 3}$ \\
\hline
\end{tabular}

Os valores da segunda coluna são os momentos de fissuração obtidos do ensaio de flexão. $\mathrm{Na}$ terceira coluna estão os valores do fator de correção $\mathrm{C}$. $\mathrm{Na}$ quarta encontram-se os valores das alturas equivalentes. Na quinta coluna estão os valores dos momentos de fissuração calculados teoricamente, considerando-se a 
seção maciça de altura $h_{\text {eq. }}$. A última coluna apresenta a relação entre os valores dos momentos de fissuração experimentais e teóricos.

Na tabela 7.3 pode-se observar que todos os modelos obtiveram momentos de fissuração teóricos maiores que os obtidos nos ensaios. Essa diferença é maior para o modelo PSF Va, que apresentava fissuras iniciais.

O menor valor do momento de fissuração obtido do ensaio foi no modelo PSF I. Verifica-se para esse modelo que a interação das placas de argamassa é proporcionada, praticamente, apenas pela placa de EPS. É de se esperar uma movimentação maior entre as faces, fazendo a seção tipo sanduíche comportar-se como uma seção parcialmente composta, com um grau de composição em função da placa de EPS. Essa composição parcial faz com que as placas apresentem separadamente uma flexão adicional em torno de seu próprio eixo (ALLEN, 1969), ocasionando uma fissuração precoce do painel.

Analisando os valores da tabela 7.3, para os modelos PSF II, PSF III, PSF IV e PSF V, verifica-se que o número de nervuras parece não interferir significativamente no valor do momento de fissuração. Nos Modelos PSFII e PSFIIa, não se verificou redução significativa de $\mathrm{M}_{\mathrm{r}}$, decorrente da inexistência da armadura de cisalhamento na nervura (redução de 6\%). A mesma conclusão não vale para os modelos PSF IV e PSF IVa, pois a redução foi de 24\%. O modelo PSF Va apresentava fissuras iniciais; por isso, o seu resultado foi desprezado na análise.

O cálculo do momento de fissuração, considerando a seção completamente composta, resulta em valores da ordem de $10 \%$ maiores que os determinados a partir da seção equivalente. A adoção dos valores do coeficiente de correção do momento de inércia, sugeridos por SHEPPARD \& PHILLIPS (1989), para compensar a perda de rigidez pela composição parcial da seção, aproxima os resultados teóricos dos experimentais. Nos casos estudados, essa redução não é suficiente.

Os valores do coeficiente $\mathrm{C}$ sugeridos por SHEPPARD \& PHILLIPS foram determinados a partir de ensaios de elementos tipo sanduíche com placas de concreto pré-moldadas, nas quais o concreto foi adensado por meio de equipamentos de vibração. Os modelos PSF, ensaiados no presente trabalho, foram executados fazendo-se uso de técnicas de projeção da argamassa, como foi descrito anteriormente. É evidente que a argamassa moldada dessa maneira não obtém o 
mesmo grau de compactação se comparada com elementos moldados, utilizando-se equipamentos de vibração. Dessa maneira, os valores de $\mathrm{C}$ sugeridos por SHEPPARD \& PHILLIPS não são os mais adequados, em virtude principalmente do modo de execução das placas.

Dos gráficos de deformações mostrados nas figuras 7.20 a 7.27, observa-se que o valor da deformação média do aço tracionado, no momento da primeira fissura (que é aproximadamente a deformação de ruptura da argamassa tracionada), para todos os modelos, é inferior a $0,05 \%$, enquanto o valor esperado $\left(\mathrm{f}_{\mathrm{tk}} / \mathrm{E}_{\mathrm{c}}\right)$ era de $0,30 \%$. O valor da deformação de ruptura depende, é claro, de vários fatores, tais como: quantidade e disposição da armadura, traço da argamassa e sua resistência à tração, cura, adensamento da argamassa etc. Dentre esses fatores, o modo como foram executadas as faces, por projeção da argamassa, provavelmente teve um peso maior no valor da deformação da argamassa na primeira fissura, ocasionando momentos de fissuração menores que o esperado.

Conforme a tabela 7.4, onde se faz um ajuste do valor de $\mathrm{C}$, observa-se que os valores médios de $\mathrm{C}=0,13$, para painéis sem nervuras, e $\mathrm{C}=0,28$ para painéis com nervura, parecem mais adequados para o caso em que as faces são executadas por técnicas de projeção. Esses valores podem ser utilizados quando o núcleo não tem participação efetiva na composição da seção, como é o caso de placas de EPS (núcleo fraco). Para casos em que o núcleo ou os conectores participam efetivamente da transmissão de cisalhamento, é necessário um estudo específico para adequar o valor de C.

TABELA 7.4 - Valores dos momentos de fissuração em kNm

\begin{tabular}{|l|c|c|c|c|c|}
\hline MODELO & $\mathbf{M}_{\mathbf{r}, \mathbf{x p}}$ & $\mathbf{C}$ & $\mathbf{h}_{\mathbf{e q}}(\mathbf{c m})$ & $\mathbf{M}_{\mathbf{r}, \text { teo }}$ & $\mathbf{M}_{\mathbf{r}, \mathbf{e x p}} / \mathbf{M}_{\mathbf{r}, \text { teo }}$ \\
\hline PSF I & 3,17 & 0,130 & 6,66 & 3,21 & $\mathbf{1 , 0}$ \\
\hline PSF II & 5,57 & 0,280 & 8,60 & 5,46 & $\mathbf{1 , 0}$ \\
\hline PSF IIa & 5,23 & 0,280 & 8,60 & 4,70 & $\mathbf{1 , 1}$ \\
\hline PSF III & 4,79 & 0,280 & 8,60 & 4,72 & $\mathbf{1 , 0}$ \\
\hline PSF IV & 4,71 & 0,280 & 8,60 & 5,21 & $\mathbf{0 , 9}$ \\
\hline PSF IVa & 3,57 & 0,280 & 8,60 & 4,62 & $\mathbf{0 , 8}$ \\
\hline PSF V & 5,31 & 0,280 & 8,60 & 5,11 & $\mathbf{1 , 0}$ \\
\hline PSF Va & 3,37 & 0,280 & 8,60 & 5,11 & $\mathbf{0 , 7}$ \\
\hline
\end{tabular}




\subsubsection{Momento de ruptura}

Para todos os modelos, o ensaio foi interrompido por causa da deformação e abertura de fissura excessivas do painel. A fig.7.18 mostra um modelo sendo ensaiado em uma etapa próxima da ruptura, podendo-se observar o painel bastante deformado. Para os modelos PSF-II, PSF-II $a$, PSF-IV, PSF-IVa, PSF-V e PSF-Va, as fissuras nas nervuras se desenvolviam durante o ensaio, passando para a placa comprimida. À medida que a carga era aplicada, essas fissuras aumentavam sua abertura e extensão, provocando um estado de fissuração inaceitável (fig.7.19).

Todos os modelos foram dimensionados para um momento de 9,3kNm. Esse valor foi adotado a partir de esforços atuantes, supondo-se um muro de arrimo de $2,85 \mathrm{~m}$ de altura com contrafortes distanciados de $3 \mathrm{~m}$.

Foram adotadas para o dimensionamento as hipóteses de cálculo do concreto armado segundo a NBR 6118, supondo o painel completamente composto, ou seja, desprezou-se o deslocamento relativo entre as faces. A comparação entre os valores teóricos e os experimentais permitem avaliar se as hipóteses utilizadas são apropriadas ou não para o dimensionamento de painéis tipo sanduíche, com nervuras. Para o cálculo do momento de ruptura teórico, foram tomados os valores das propriedades dos materiais (aço e concreto) obtidos nos ensaios.

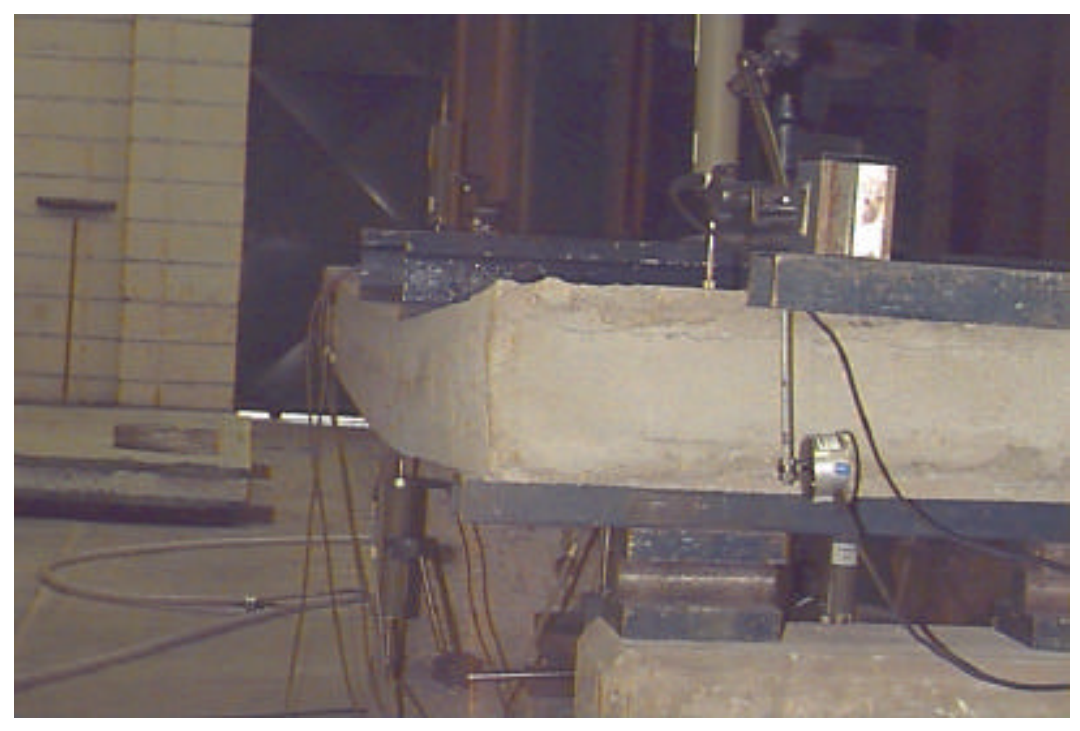

FIGURA 7.18 - ENSAIO DE FLEXÃO EM UMA ETAPA PRÓXIMA DA RUPTURA 


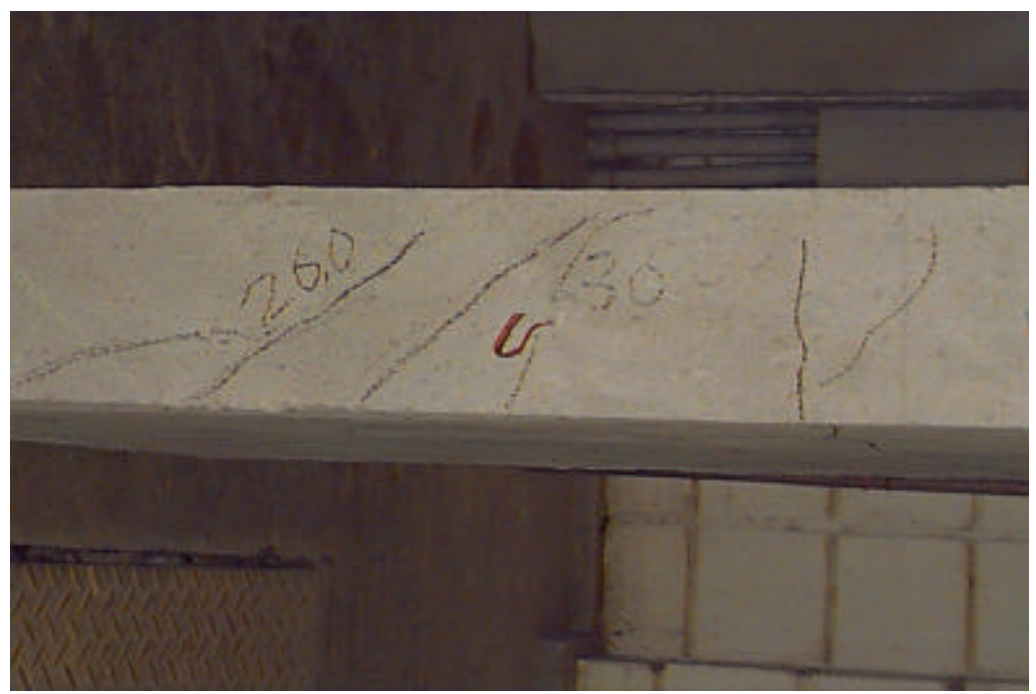

FIGURA 7.19 - FISSURAS NUMA ETAPA DO ENSAIO PRÓXIMA DA RUPTURA - PSF-IV

A tabela 7.5 mostra o resumo dos valores dos momentos de ruptura para cada modelo ensaiado, bem como uma comparação desses com os valores teóricos, calculados a partir das hipóteses do concreto armado.

TABELA 7.5 - Valores teóricos e experimentais dos momentos de ruptura em kNm.

\begin{tabular}{|l|c|c|c|}
\hline MODELO & $\mathbf{M}_{\text {últ,exp }}$ & $\mathbf{M}_{\text {últ, teo }}$ & $\mathbf{M}_{\text {exp }} / \mathbf{M}_{\text {teo }}$ \\
\hline PSF I & 7,08 & 9,3 & $\mathbf{0 , 7 6}$ \\
\hline PSF II & 12,73 & 9,3 & $\mathbf{1 , 3 7}$ \\
\hline PSF IIa & 9,44 & 9,3 & $\mathbf{1 , 0 2}$ \\
\hline PSF III & 7,45 & 9,3 & $\mathbf{0 , 8 0}$ \\
\hline PSF IV & 12,98 & 9,3 & $\mathbf{1 , 4 0}$ \\
\hline PSF IVa & 8,63 & 9,3 & $\mathbf{0 , 9 3}$ \\
\hline PSF V & 13,7 & 9,3 & $\mathbf{1 , 4 7}$ \\
\hline PSF Va & 10,27 & 9,3 & $\mathbf{1 , 1 0}$ \\
\hline
\end{tabular}

A segunda e a terceira colunas apresentam, respectivamente, os valores dos momentos últimos obtidos nos ensaios e os momentos últimos teóricos. Esses últimos foram calculados considerando-se a seção completamente composta. A última coluna contém a relação entre os valores experimentais e os valores esperados.

O valor do momento último obtido no ensaio, para o modelo sem nervura (PSF I), foi $24 \%$ menor que o valor esperado. A transferência de esforços de uma placa para outra é realizada, em grande parte, por meio da placa de EPS, que, apesar de não ter rigidez elevada, garante a composição parcial do painel. Se a seção 
funcionasse sem nenhuma interação (não-composto), o valor teórico do momento último seria de aproximadamente 2,60 $\mathrm{kNm}$, utilizando-se a mesma armadura. $\mathrm{O}$ ganho de resistência à flexão conseguida pelo afastamento das placas, mesmo utilizando-se uma placa de EPS como núcleo, é algo em torno de $258 \%$.

Da mesma maneira, no modelo PSF III, com nervura apenas nas extremidades transversais, obteve-se um momento último $20 \%$ menor que o valor esperado. Verificou-se nesse painel um pequeno aumento no momento último, da ordem de $5 \%$, em relação ao modelo PSF I. Pode-se dizer que as nervuras do modelo PSF III tiveram pouca contribuição na ruptura do painel à flexão. Se as nervuras tivessem espessuras maiores, seria de se esperar que o grau de composição da seção aumentasse.

As figuras 7.20 e 7.21 mostram as deformações da placa comprimida e da armadura tracionada, respectivamente, para os modelos PSF I e PSF III.

A deformação média na placa comprimida no modelo PSF I foi maior que no modelo PSF III. Da mesma forma, a deformação média de tração no aço foi ligeiramente maior. A composição adicional proporcionada pelas nervuras do modelo PSF III justifica essa diferença. À medida que aumenta o grau de composição da seção, há um decréscimo nas deformações no concreto e no aço, pois a interação das placas é cada vez maior, como pode ser verificado nas figuras que mostram as deformações nos painéis com maior número de nervuras (figuras 7.22 a 7.27). 

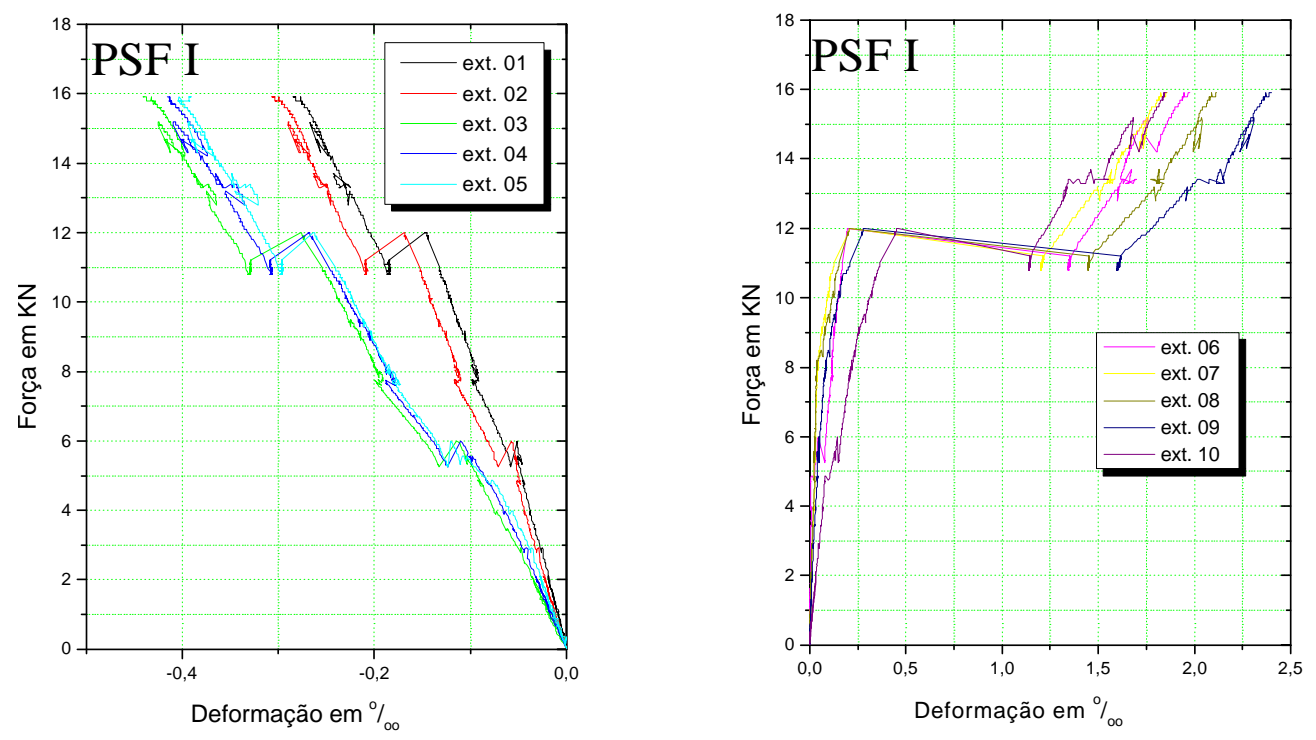

FIGURA 7.20 - DEFORMAÇÕES NO PAINEL PSF I
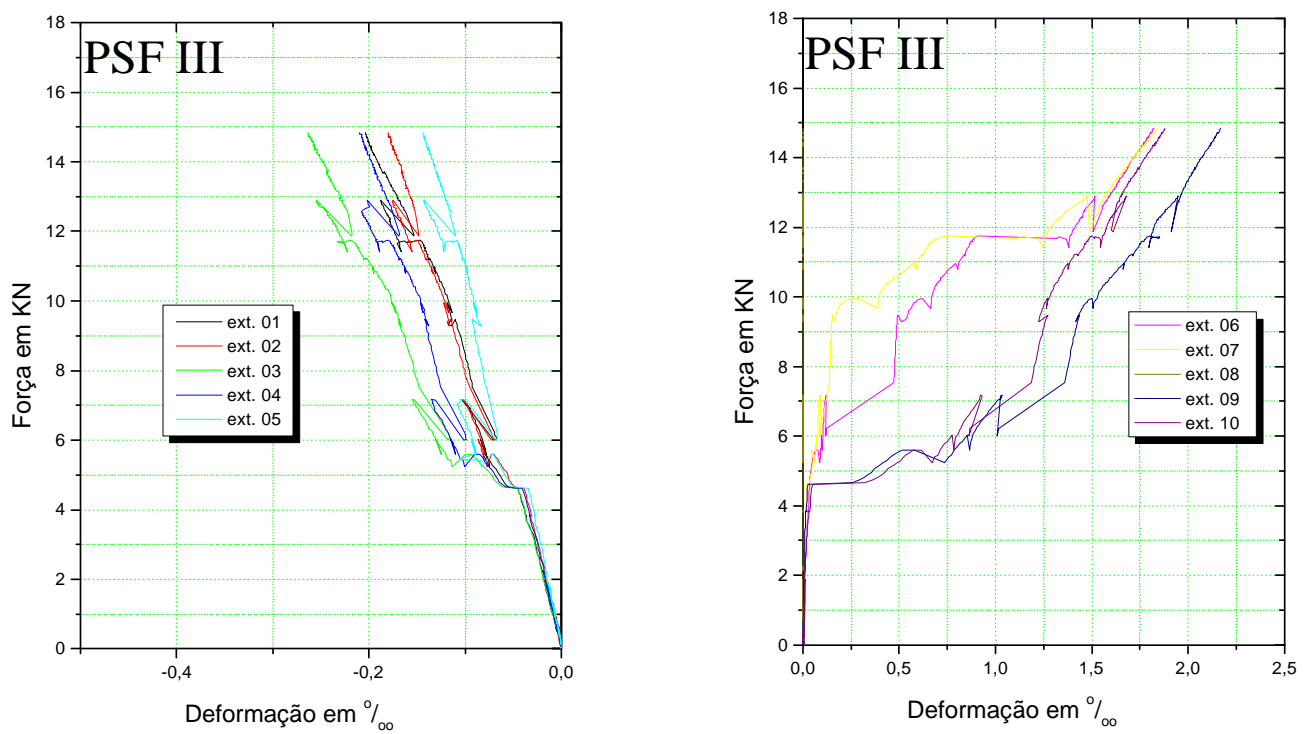

FIGURA 7.21 - DEFORMAÇÕES NO PAINEL PSF III

As rupturas dos painéis PSF I e PSF III coincidem com o início do escoamento do aço, conforme os gráficos de deformação do aço das figuras $7.20 \mathrm{e}$ 7.21 .

Voltando à tabela 7.5, observa-se que, para os modelos com nervuras longitudinais (PSF II, PSF IIa, PSF IV, PSF V e PSF Va), exceto para o PSF IVa, os valores dos momentos últimos obtidos do ensaio superaram os valores esperados. É interessante notar que a armadura das nervuras melhorou de maneira significativa a resistência à flexão dos painéis PSF II, PSF IV e PSF V. Comprova-se isto 
comparando os valores da coluna 4 da tabela 7.5 dos modelos com armadura nas nervuras e sem armadura, estas caracterizadas pela letra a.

Apesar de os modelos com nervuras longitudinais sem armadura terem atingido os valores esperados, exceto o PSF IVa, é inteiramente recomendável que na prática se utilize uma armadura mínima nas nervuras, que comprovadamente melhora o comportamento à flexão.

As figuras 7.22 a 7.27 mostram os diagramas de deformações de compressão no concreto e no aço tracionado, para os modelos PSF II, PSF IIa, PSF IV, PSF IVa, PSF V, PSF Va.

No dimensionamento da seção dos modelos, obteve-se uma seção de armadura de $1,54 \mathrm{~cm}^{2}$, considerando-se a peça no domínio 2. A deformação no concreto determinada teoricamente foi de $0,4 \%$, para uma deformação do aço de 10 $\%$. Para os modelos com nervuras armadas (PSF II, PSF IV, PSF V), o valor médio das deformações no concreto, obtido do ensaio para cada painel, está em torno de $0,4 \%$. A armadura tracionada se encontra em escoamento para esses mesmos modelos no momento da ruptura, visto que o escoamento do aço CA 50 inicia com $2,07 \%$. Dessa forma, confirmam-se as hipóteses utilizadas no dimensionamento.

Observa-se nos diagramas de deformações no concreto e no aço que os modelos com nervuras sem armadura (PSF IIa, PSF IVa e PSF Va) obtiveram deformações menores no momento da ruptura, se comparados aos respectivos modelos com nervuras armadas (PSF II, PSF IV, PSF V). Comprova-se com isto que as nervuras armadas desempenharam um papel importante, melhorando sobremaneira o comportamento dos painéis à flexão, aumentando o grau de composição entre as faces, fazendo com que se chegue a valores maiores de carga de ruptura. 

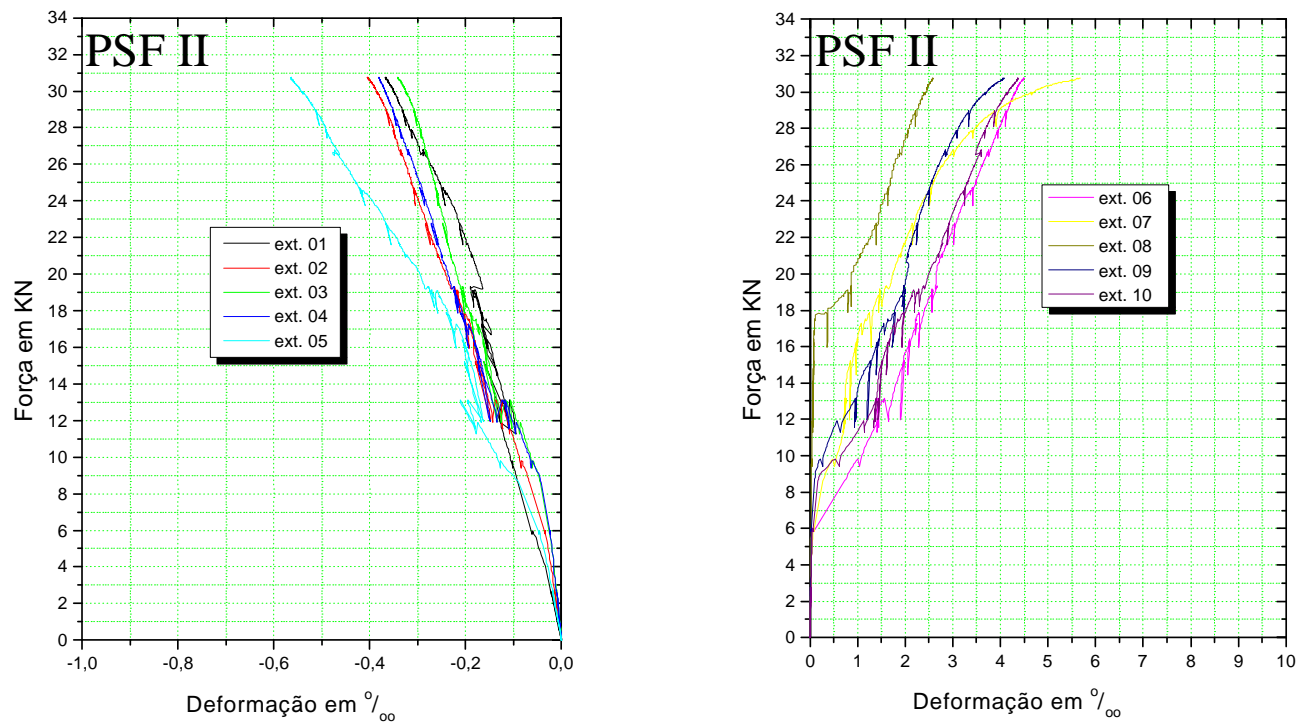

FIGURA 7.22 - DEFORMAÇÕES NO PAINEL PSF II
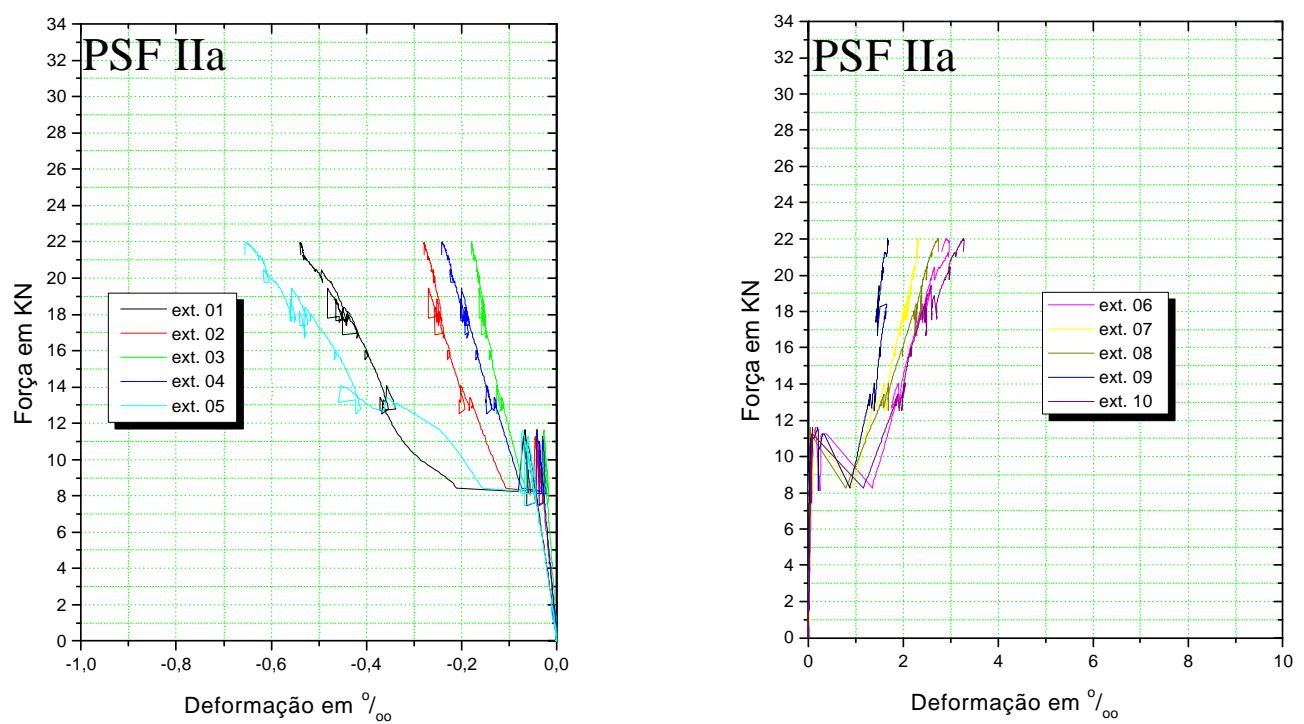

FIGURA 7.23 - DEFORMAÇÕES NO PAINEL PSF IIa 

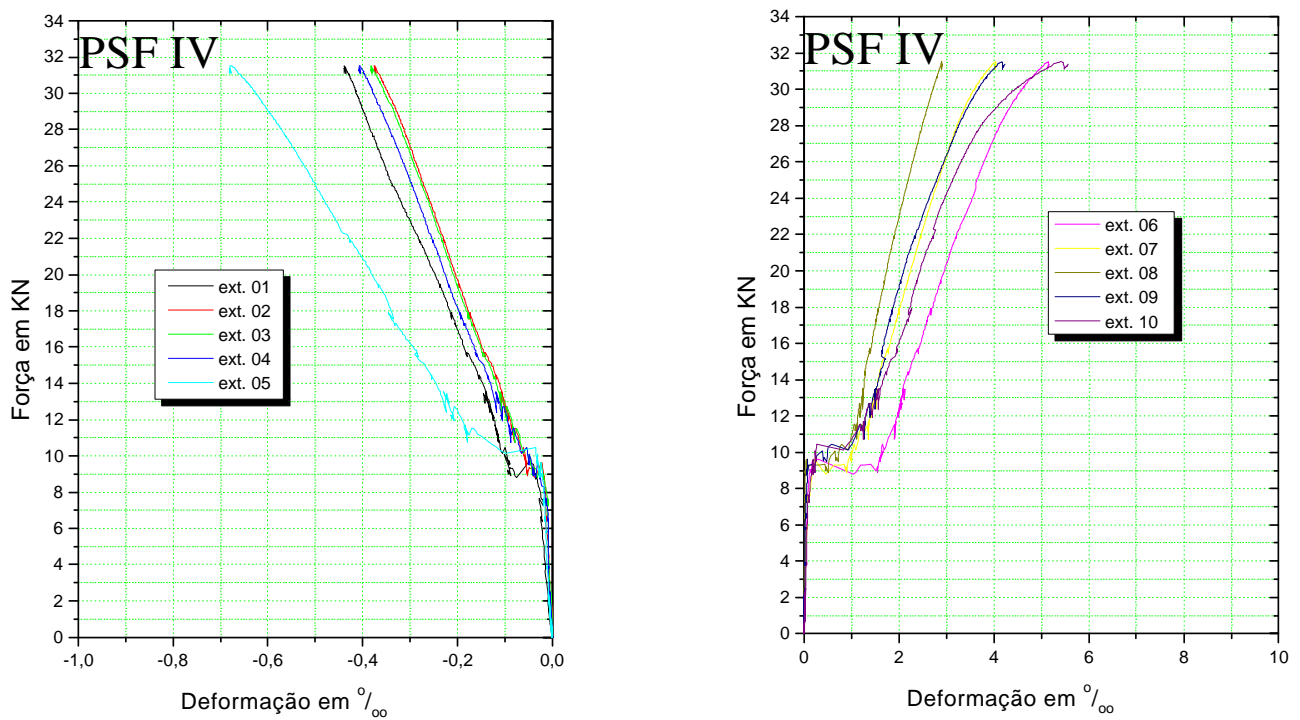

FIGURA 7.24 - DEFORMAÇÕES NO PAINEL PSF IV
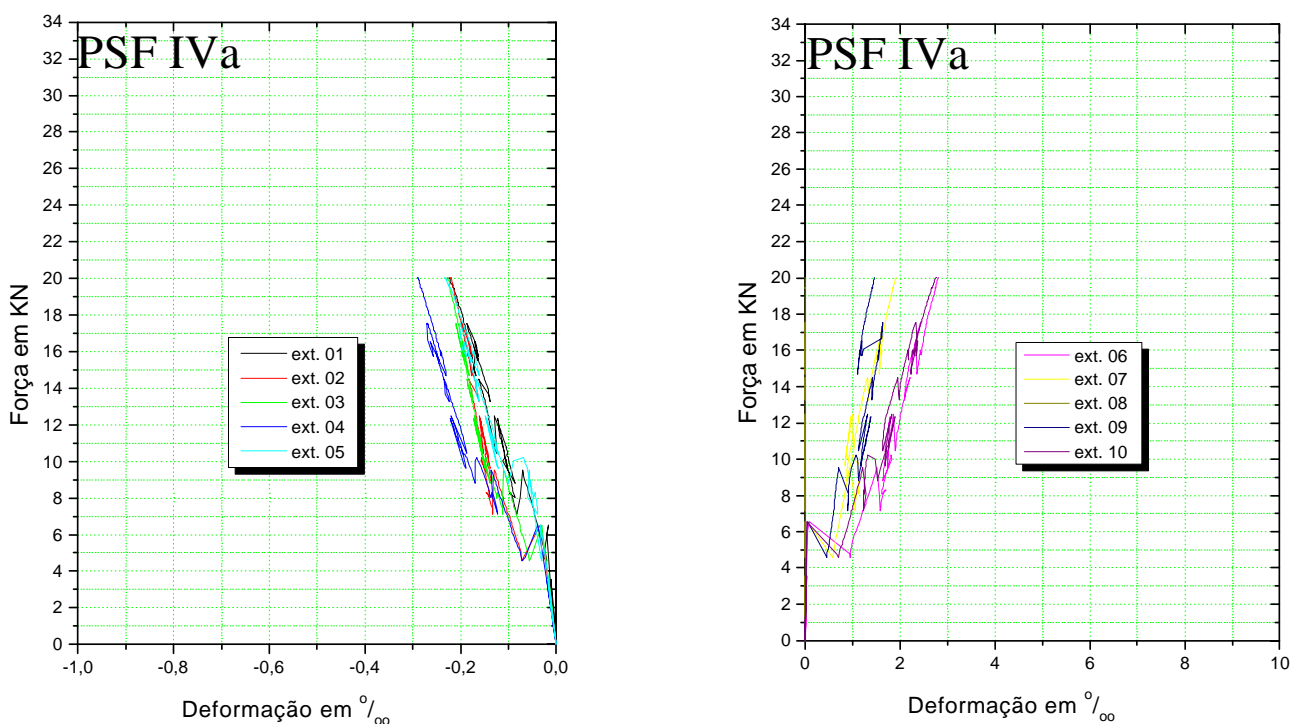

FIGURA 7.25 - DEFORMAÇÕES NO PAINEL PSF IVa 

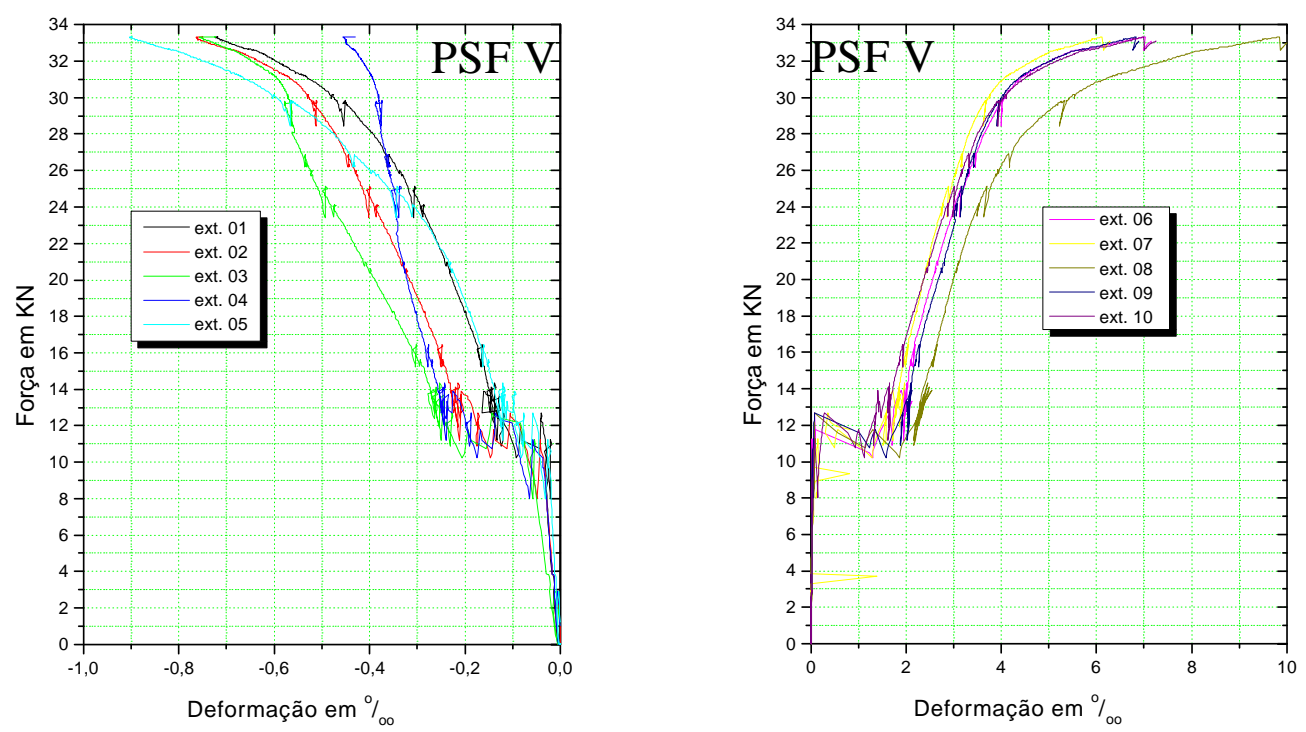

FIGURA 7.26 - DEFORMAÇÕES NO PAINEL PSF V
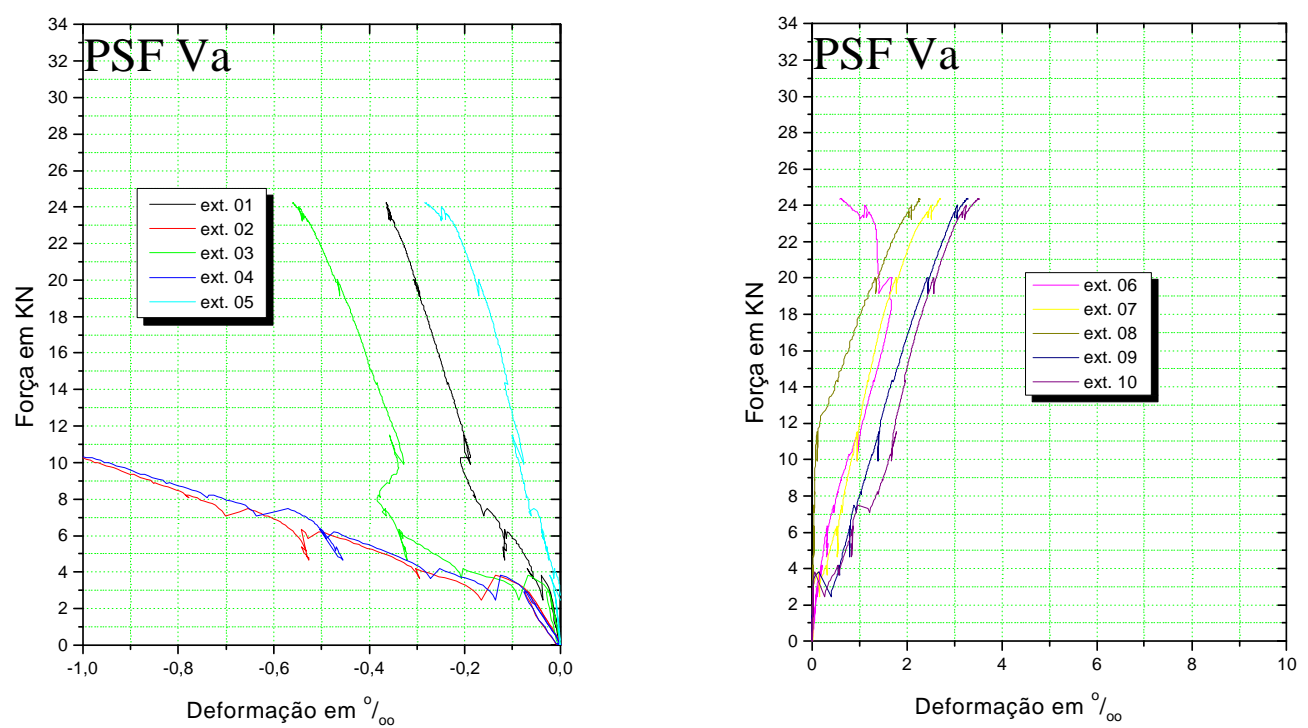

FIGURA 7.27 - DEFORMAÇÕES NO PAINEL PSF Va

Conforme a tab.7.5, o momento último obtido no ensaio para o modelo PSF II foi de $12,73 \mathrm{kNm}$, e para os modelos PSF IV e PSF V foram, respectivamente, de $12,98 \mathrm{kNm}$ e $13,70 \mathrm{kNm}$. O modelo PSF II foi executado com nervuras nas bordas longitudinais. O modelo PSF IV tinha nervuras nas bordas longitudinais e transversais, e o PSF V incluía ainda uma nervura longitudinal pelo meio do painel. Mesmo o modelo PSF $\mathrm{V}$ possuindo maior número de nervuras que os outros modelos, isto não implicou em um valor da carga última muito maior que nos 
demais. Aconteceu o mesmo para os modelos com nervuras sem armadura (PSF IIa, PSF IVa e PSF Va).

Pode-se concluir que um menor espaçamento entre as nervuras não representa um ganho significativo no comportamento do painel tipo sanduíche à flexão, no estado limite último. Pensando-se em termos de execução do elemento, não compensa dobrar o número de nervuras, visto que o ganho em termos de resistência à flexão não é proporcional ao aumento do número de nervuras.

\subsubsection{Deslocamentos}

O ensaio foi conduzido com controle de deformação, a uma velocidade de $0,03 \mathrm{~mm} / \mathrm{s}$, e a cada 2 segundos os dados de força e deslocamentos eram registrados pelo sistema de aquisição de dados. A aplicação da carga era momentaneamente paralisada, a cada $2 \mathrm{kN}$, para verificação das fissuras. Na fig.7.28 apresenta-se, no mesmo diagrama, a relação Força x Deslocamento para todos os modelos ensaiados. Pode-se tirar as seguintes observações desse gráfico:

i) Nos modelos sem nervuras (PSF-I e PSF-III), os deslocamentos foram bem maiores que os modelos com nervuras;

ii) A presença de nervuras transversais nas extremidades do modelo PSF-III não contribuíram de forma significativa na resistência à flexão, quando comparadas ao modelo PSF-I;

iii) A armadura nas nervuras dos modelos PSF-II, PSF-IV e PSF-V melhoraram de maneira significativa a resistência à flexão. Para esses modelos, o momento último obtido no ensaio foi quase o dobro do valor do momento último obtido no ensaio do PSF-I;

iv) As curvas Força x Deslocamentos para os modelos com nervuras longitudinais tiveram comportamento parecido (com exceção do PSF-Va, pela presença de fissuras iniciais decorrentes da retração da argamassa) até por volta da carga referente à primeira fissura;

v) Os modelos PSF-II e PSF-IIa, PSF-IV e PSF-IVa, PSF-V e PSF-Va, correspondentes aos painéis com nervuras e, respectivamente, com e sem armadura de cisalhamento, apesar de os comportamentos terem sido muito próximos, os modelos com nervuras e sem armadura romperam com momentos últimos da ordem de $30 \%$ menores que os modelos com nervuras e com 
armadura. Isto comprova a importância da armadura nas nervuras, melhorando o comportamento à flexão no estado limite último;

vi) O maior número de nervuras longitudinais no PSF-V (três) não correspondeu a um ganho significante de resistência à flexão, quando comparado ao PSF-IV e PSFII, que possuíam duas nervuras longitudinais. Observa-se, entretanto, uma melhora na rigidez do painel, apresentando menores deslocamentos.

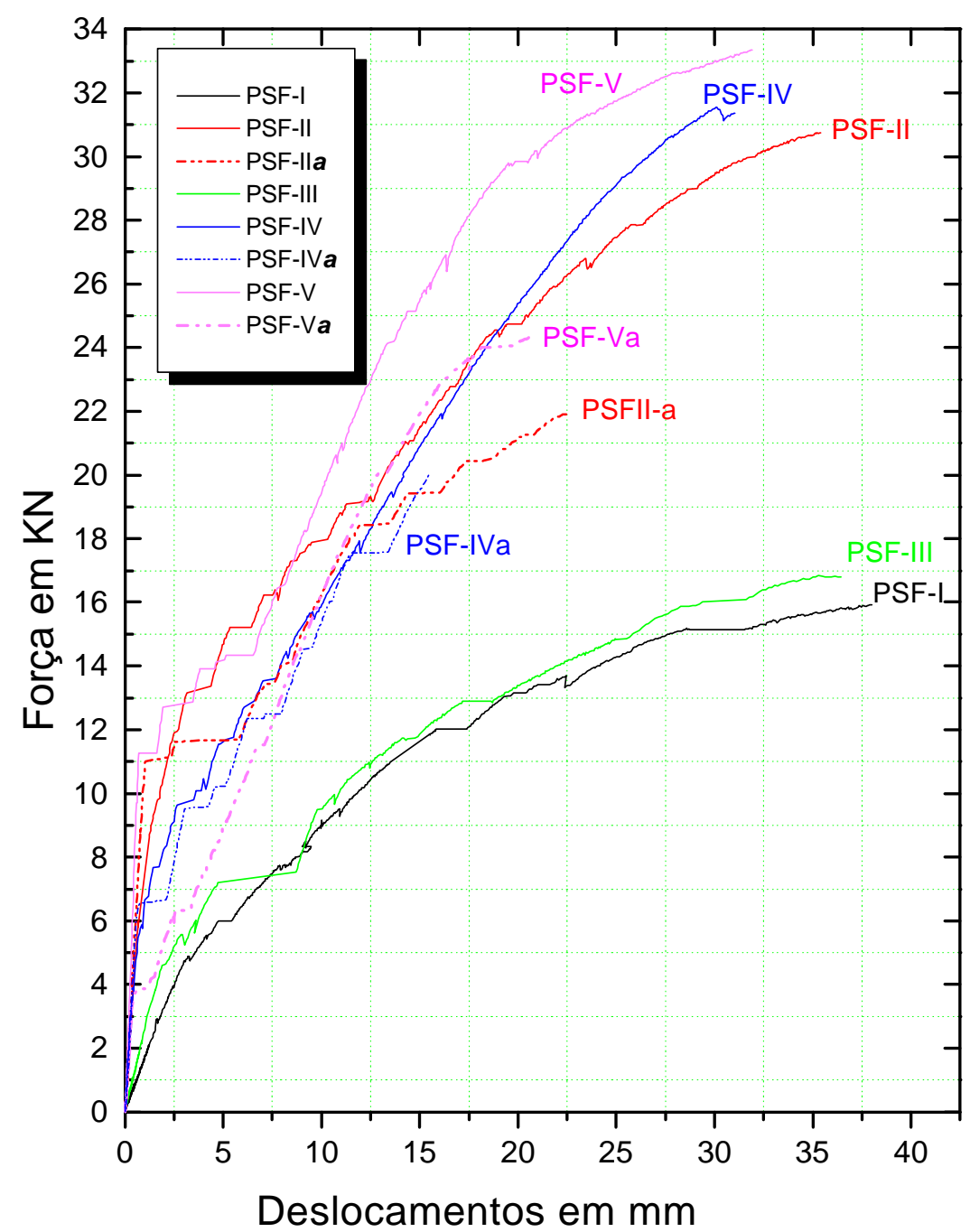

FIGURA 7.28 - GRÁFICO FORÇA X DESLOCAMENTOS PARA TODO OS MODELOS ENSAIADOS À FLEXÃO

Para comparação com os resultados experimentais, foram calculados os deslocamentos considerando-se o modelo como uma viga biapoiada, através da eq.6.5. 
O módulo de elasticidade médio foi de $28.000 \mathrm{MPa}$, obtido através dos ensaios de controle da argamassa. Esse ensaio foi realizado em corpos-de-prova cilíndricos de $10 \mathrm{~cm}$ x $20 \mathrm{~cm}$, para cada etapa de projeção da argamassa, para cada modelo.

No cálculo dos deslocamentos teóricos, foi considerada a perda de rigidez devida à:

a) fissuração da argamassa;

b) movimentação relativa entre as faces (seção parcialmente composta).

Inicialmente considerou-se o momento de inércia para a peça no estádio I (momento atuante menor que o momento de fissuração). Para o momento atuante maior que o momento de fissuração, o cálculo dos deslocamentos foi feito utilizandose o momento de inércia efetivo $\left(I_{e}\right)$, situado entre o momento de inércia do estádio I e o do estádio II, pois a peça apresenta regiões fissuradas intercaladas por regiões não fissuradas, configurando assim uma situação intermediária entre os dois estádios. O momento de inércia $I_{e}$ foi obtido através da expressão 6.6 (Fórmula de Branson), fornecida pelo ACI.

Para cada valor da força aplicada superior ao correspondente ao momento de fissuração, o momento de inércia $I_{e}$ varia, sendo calculado pela eq.6.6, construindose assim a curva teórica Força $\mathrm{x}$ Deslocamento, considerando-se a perda de rigidez da peça ao longo do ensaio, após a abertura da primeira fissura.

A perda de rigidez pelo movimento relativo entre as faces foi calculada corrigindo-se o valor do momento de inércia através do coeficiente de correção, segundo SHEPPARD \& PHILLIPS (1989), da mesma maneira como foi feito para o momento de fissuração. Para a construção dos gráficos da figura 7.29 e 7.30 adotouse $\mathrm{C}=0,22$ para o modelo PSF I, e $\mathrm{C}=0,39$ para os demais modelos.

Os diagramas das figuras 7.31 e 7.32 foram feitos adotando-se $\mathrm{C}=0,13$ para painéis sem nervuras e $\mathrm{C}=0,28$ para painéis com nervuras, que consideram o modo como as faces são executadas (por projeção da argamassa).

Foi construída, também, para todos os gráficos, a curva Força $x$ Deslocamento considerando-se o painel sem nenhuma interação das placas de argamassa (não-composto). O deslocamento para o caso não-composto é aquele verificado em apenas uma das placas do painel, submetida à metade da carga. $\mathrm{O}$ 
cálculo foi feito considerando-se uma viga biapoiada, com forças aplicadas nos terços.
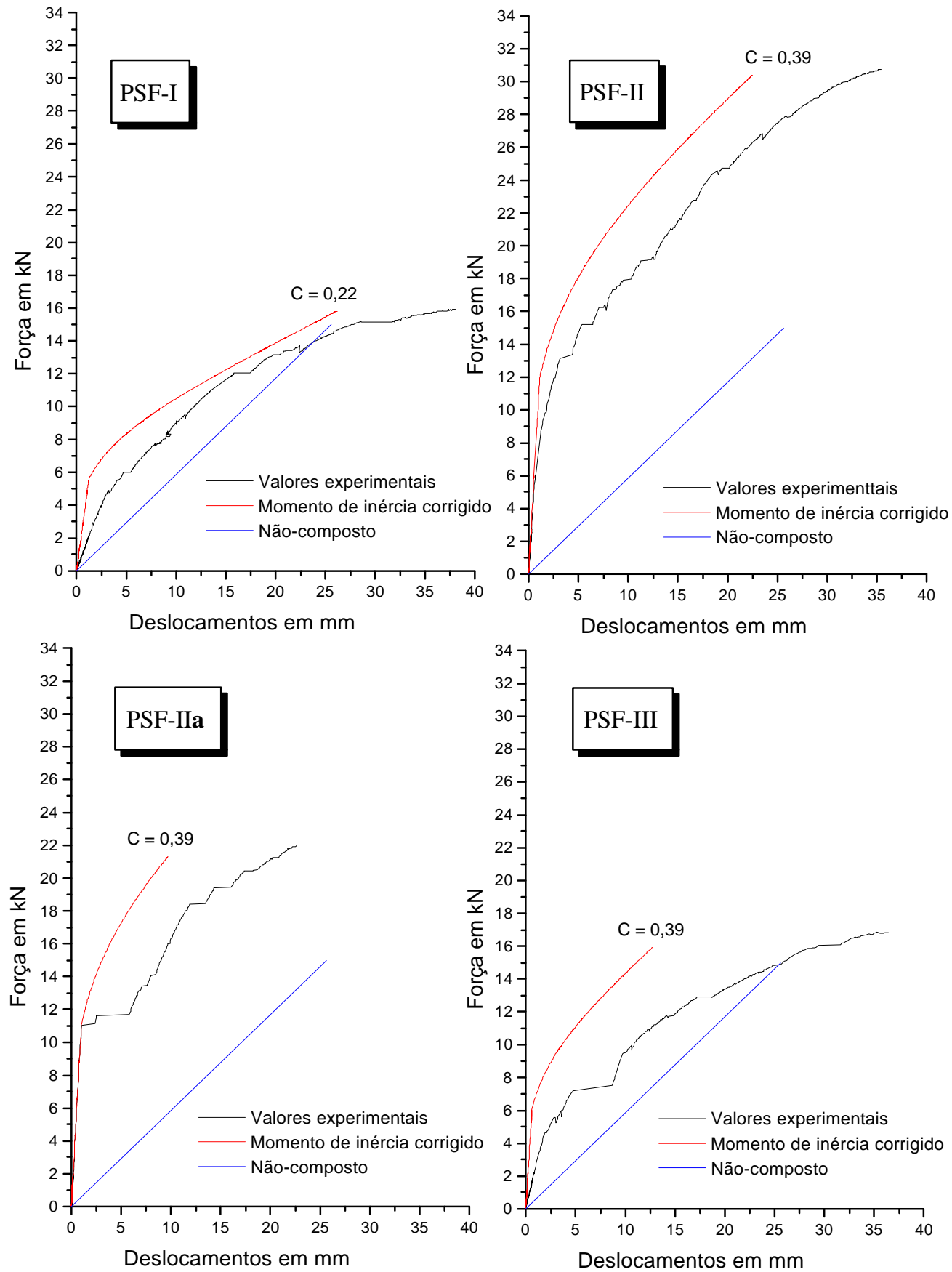

FIGURA 7.29 - COMPARAÇÃO TEÓRICA X EXPERIMENTAL DO GRÁFICO FORÇAXDESLOC. DOS MODELOS PSF-I, PSF-II, PSF-II $a$ E PSF-III 

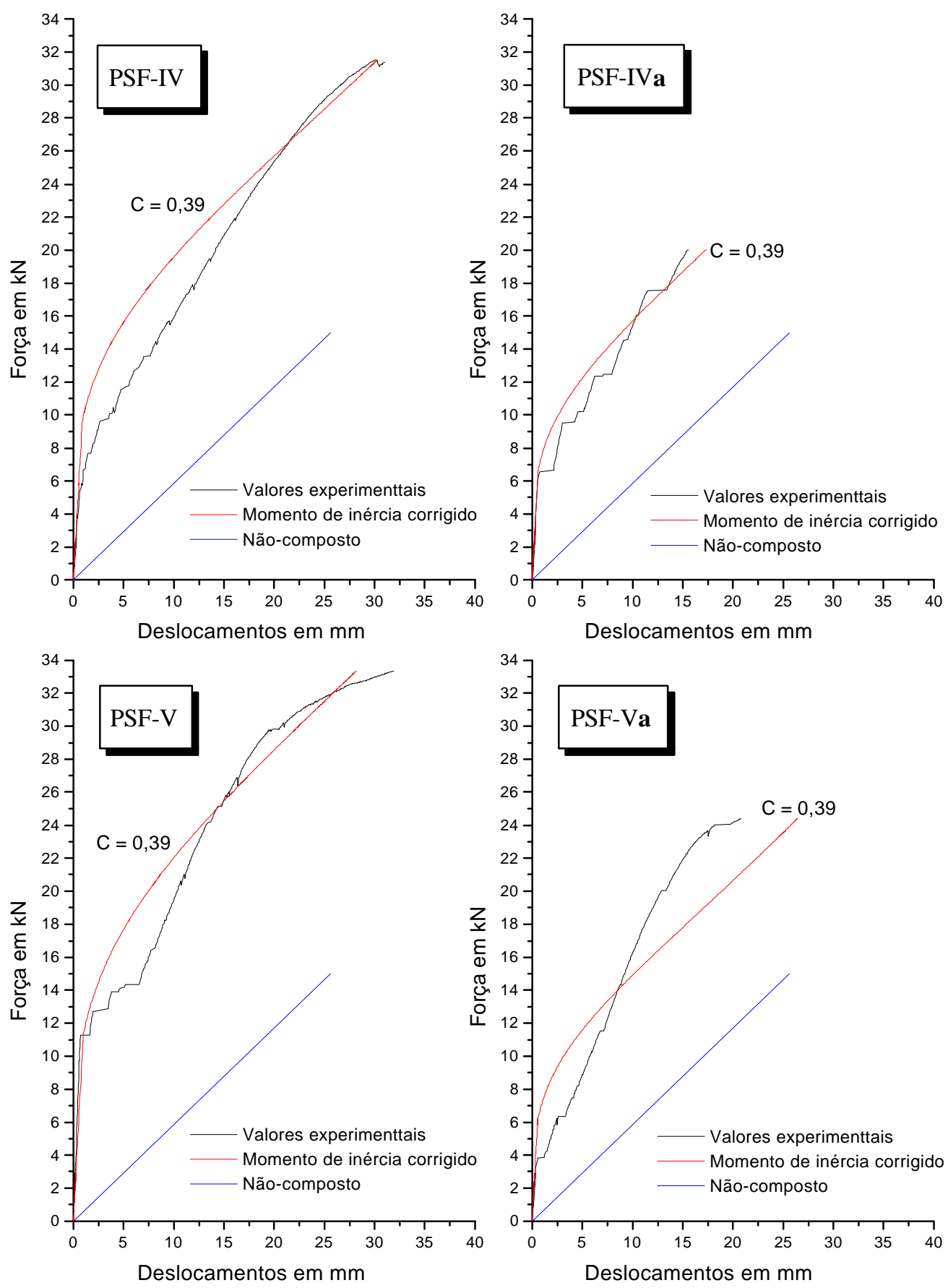

FIGURA 7.30 - COMPARAÇÃO TEÓRICA X EXPERIMENTAL DO GRÁFICO FORÇAXDESLOC. DOS MODELOS PSF-IV, PSF-IV $\boldsymbol{a}$, PSF-V E PSF-V $\boldsymbol{a}$ 

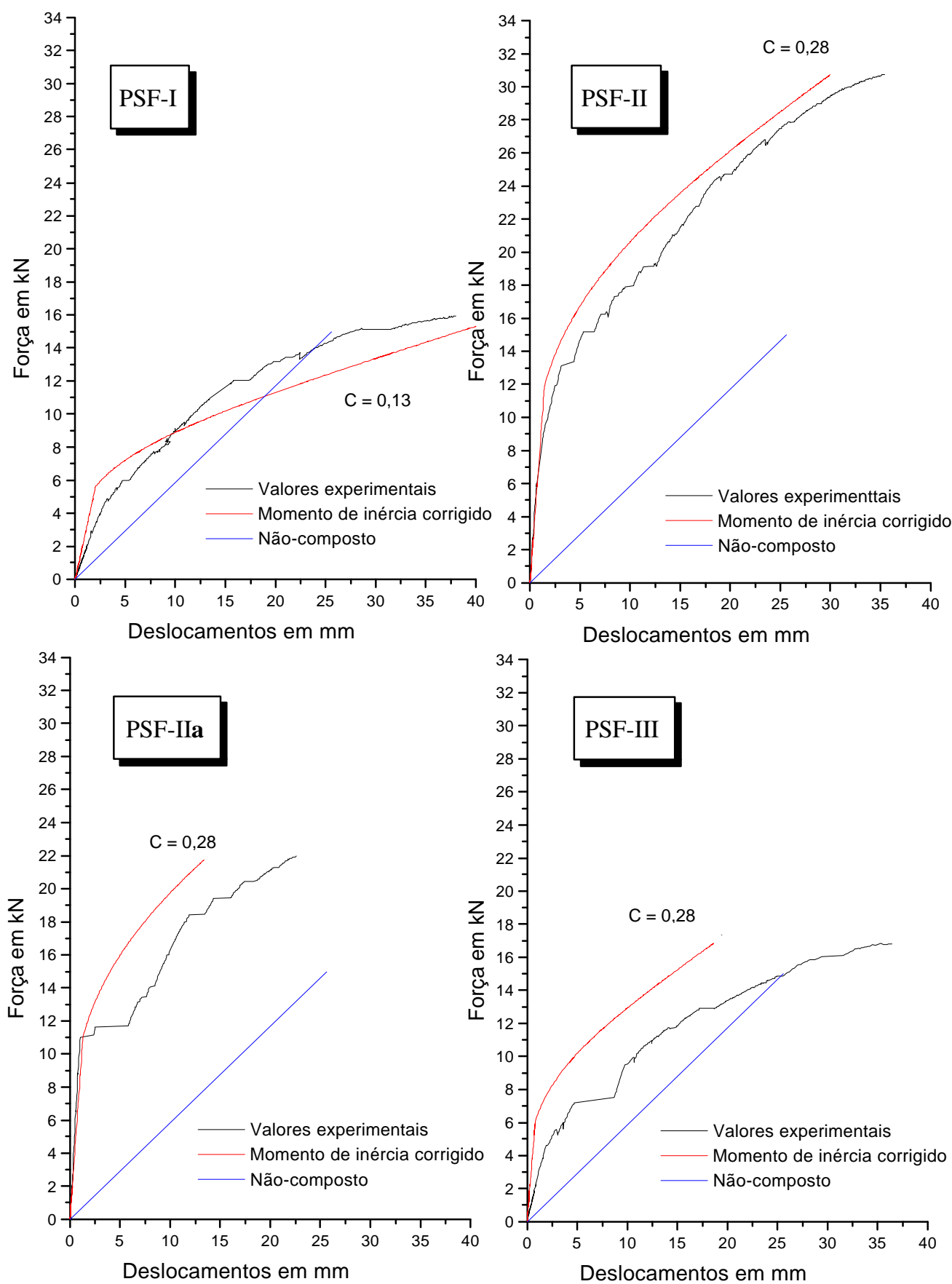

FIGURA 7.31 - COMPARAÇÃO TEÓRICA X EXPERIMENTAL DO GRÁFICO FORÇAXDESLOC. DOS MODELOS PSF-I, PSF-II, PSF-II $a$ E PSF-III 

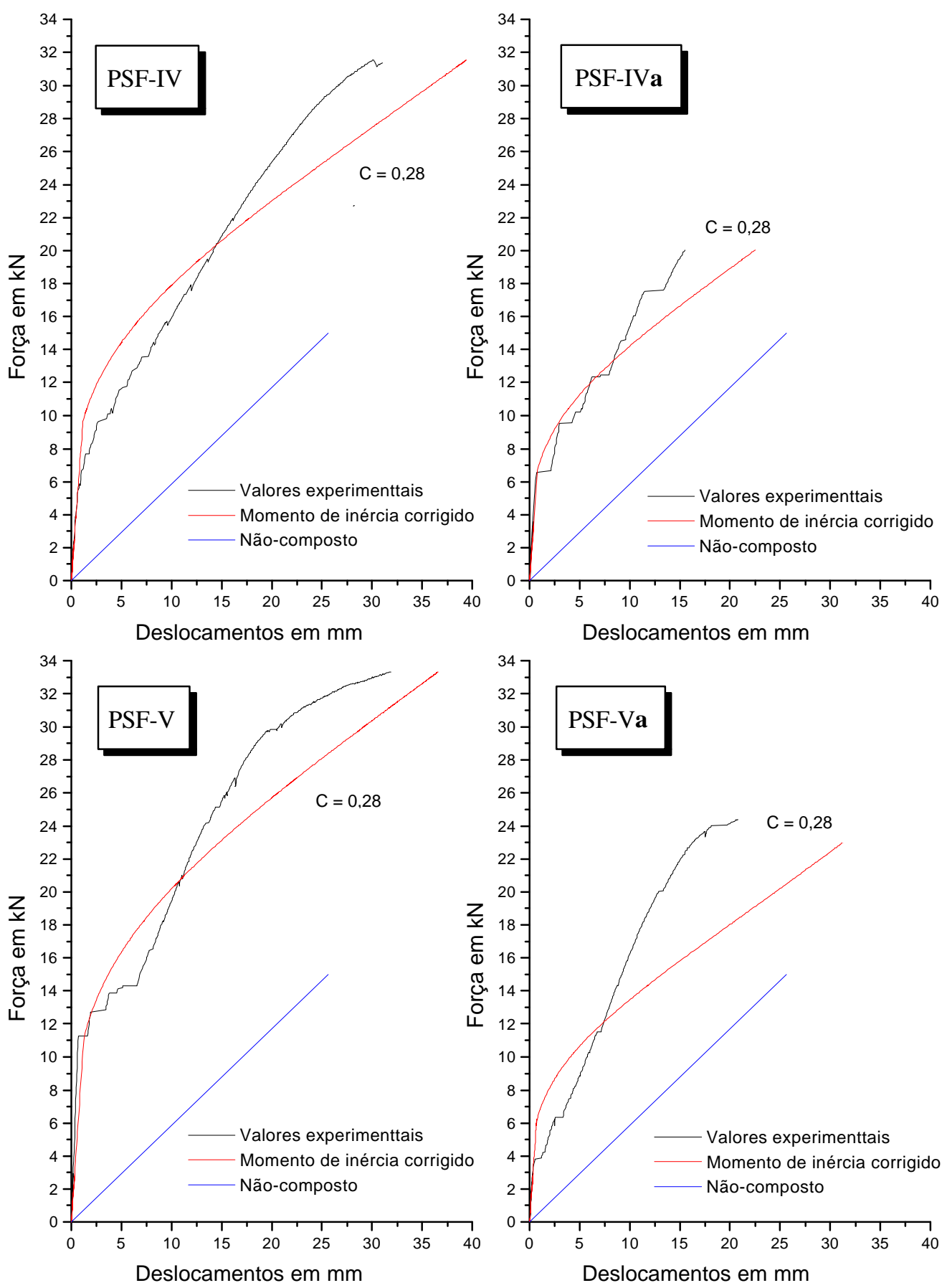

FIGURA 7.32 - COMPARAÇÃO TEÓRICA X EXPERIMENTAL DO GRÁFICO FORÇAXDESLOC. DOS MODELOS PSF-IV, PSF-IV $\boldsymbol{a}$, PSF-V E PSF-V $\boldsymbol{a}$

Em termos de deslocamentos, o modelo PSF I teve um comportamento muito próximo do relativo a uma seção tipo sanduíche não-composta. Comparando-se os gráficos, para esse modelo (figuras 7.29 e 7.31), nota-se que os deslocamentos 
teóricos calculados, considerando-se o valor de $\mathrm{C}=0,13$, fornecem melhores resultados.

O modelo PSF III, apesar de possuir nervuras apenas nas extremidades de apoio, teve um comportamento muito próximo do PSF I. Conclui-se então que essas nervuras pouco contribuíram no comportamento do elemento, em termos de deslocamentos. Pelo observado na curva experimental do modelo PSF III, a curva teórica dos deslocamentos, para os dois valores adotados de $\mathrm{C}$, não corresponde a bons resultados. Adotando $\mathrm{C}=0,13$ para esse modelo, obtêm-se melhores resultados para os deslocamentos, comparados com os valores obtidos experimentalmente, conforme pode ser visto no gráfico da fig.7.33.

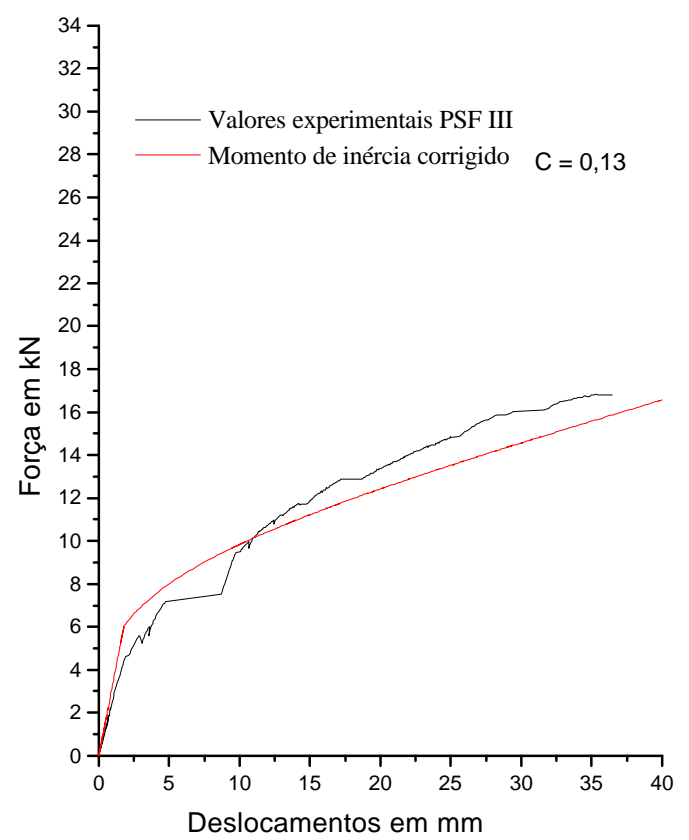

FIGURA 7.33 - COMPARAÇÃO TEÓRICA X EXPERIMENTAL PSF III. C = 0,13

Observa-se nas figuras 7.29 e 7.30 que os gráficos dos deslocamentos teóricos, considerando-se os valores de SHEPPARD \& PHILLIPS, se aproximam bastante das curvas experimentais, apenas para os modelos com nervuras em toda a borda (PSF IV, PSF IVa, PSF V e PSF Va). Para os demais modelos (PSF II e PSF IIa), as curvas teóricas resultaram em valores menores dos deslocamentos que os obtidos nos ensaios. Em relação a esses dois últimos modelos, a utilização de 
$\mathrm{C}=0,28$ (fig.7.31) fornece resultados melhores, comparados com os valores obtidos para $\mathrm{C}=0,39$ (fig.7.30).

De maneira geral, os valores de $\mathrm{C}=0,13$ - modelos sem nervuras longitudinais - e $\mathrm{C}=0,28$ - modelos com nervuras longitudinais - apresentam resultados melhores que os outros valores adotados de C.

\subsection{CONCLUSÕES PARCIAIS}

Analisando-se os resultados dos ensaios e as comparações teóricas, pode-se tirar as seguintes conclusões:

a) O momento de fissuração de um elemento fletido com seção tipo sanduíche, com faces de argamassa projetada e núcleo fraco, pode ser calculado com boa aproximação utilizando-se as hipóteses de cálculo do concreto armado segundo a norma NBR 6118. A seção considerada no cálculo corresponde a uma seção maciça equivalente, determinada a partir da redução do momento de inércia da seção tipo sanduíche por um coeficiente $\mathrm{C}$, que leva em conta a perda de rigidez pela movimentação relativa entre as faces. Adotando-se $\mathrm{C}=0,13$ para painéis sem nervuras e $\mathrm{C}=0,28$ para painéis com nervuras longitudinais, os valores obtidos são muito próximos dos momentos de fissuração obtidos experimentalmente;

b) O dimensionamento à flexão de painéis tipo sanduíche com nervuras pode ser feito utilizando-se as mesmas hipóteses de cálculo do concreto armado segundo a NBR 6118;

c) No caso dos elementos tipo sanduíche sem nervuras submetidos à flexão, quando dimensionados pelas mesmas hipóteses do concreto, deve-se aplicar um fator de majoração no momento de cálculo. O valor desse fator é dado em função da interação proporcionada pelo núcleo ou pelos elementos de ligação das placas resistentes. Para o caso de núcleo de espuma rígida, como é o caso do EPS, o momento de cálculo pode ser aumentado em torno de $24 \%$, conforme a análise dos resultados dos ensaios, para que o valor do momento de ruptura atinja o esperado;

d) A utilização de armadura nas nervuras aumenta significativamente (cerca de $30 \%$ ) os valores dos momentos últimos, em relação aos modelos com nervuras e sem armadura; 
e) O número de três nervuras longitudinais no modelo PSF-V não proporcionou ganho significante de resistência à flexão, em relação aos modelos PSF-II e PSFIV, que tinham apenas duas nervuras;

f) Foram obtidos bons resultados no cálculo dos deslocamentos de elementos fletidos com seção tipo sanduíche, com faces de argamassa moldadas por meio de técnicas de projeção, considerando-se uma seção equivalente, da mesma maneira como foi feito no cálculo do momento de fissuração, e utilizando-se os mesmos valores dos coeficientes de correção do momento de inércia, para cada caso (sem nervura ou com nervura). 


\section{CONSIDERAÇÕES FINAIS}

Ao final deste trabalho, verifica-se que foi atingido o objetivo inicialmente proposto, que trata do estudo de estruturas mistas tipo sanduíche.

São descritas, a seguir, as conclusões, bem como propostas para a continuidade das pesquisas.

\subsection{CONCLUSÕES}

A revisão bibliográfica mostra que em edificações, sejam elas residenciais, comerciais ou mesmo industriais, se encontra a principal aplicação de elementos tipo sanduíche, que utiliza faces resistentes de argamassa moldadas no local da obra, executadas por processos de projeção. Esse método construtivo tem sido aplicado no Brasil e em outros países, baseando-se principalmente na experiência dos construtores, existindo pouquíssima literatura tratando de projeto e execução de acordo com esse método.

Considerando a deficiência nessa área do conhecimento científico, este trabalho vem contribuir para viabilizar o projeto de elementos tipo sanduíche, que utilizam faces resistentes moldadas por projeção da argamassa.

As vantagens inerentes ao sistema são: eliminação de formas; estrutura monolítica; rapidez de execução; estrutura rígida e resistente; redução de custos; racionalização da construção, utilizando técnicas de projeção de argamassa; possibilidade de execução da estrutura em lugares distantes dos grandes centros e de difícil acesso; utilização de mão-de-obra pouco especializada; utilização de rejeitos industriais e resíduos agrícolas na confecção de núcleos; execução da obra através da autoconstrução e possibilidade de criação de sistemas abertos ("estruturas híbridas"). Com essas características, verifica-se um forte potencial de aplicação desse método construtivo em obras de infra-estrutura, tais como galerias, muros de arrimo, reservatórios de água, canais de drenagem, entre outros. 
Dos estudos realizados, são apresentadas algumas considerações sobre os principais aspectos levantados, que se referem à resistência efetiva da argamassa projetada, ao comportamento à flexão de vigas de seção tipo sanduíche e ao comportamento à flexão e à compressão de painéis tipo sanduíche.

\subsubsection{Argamassa}

Quanto à argamassa utilizada nos modelos, realizou-se um estudo inicial, adotando-se um traço de 1:3 (relação cimento/areia) com fator a/c $=0,51$. Adicionouse $10 \%$ de sílica ativa, em relação ao peso do cimento, que melhorou a mistura, principalmente em termos de coesão e de resistência. Para garantir a trabalhabilidade necessária, adicionou-se ainda $2 \%$ de superplastificante, em relação ao peso do cimento. Essa mistura forneceu uma resistência média à compressão em torno de 60 $\mathrm{MPa}$, medida em corpos-de-prova cilíndricos de $10 \mathrm{~cm}$ x $20 \mathrm{~cm}$. O módulo de deformação longitudinal médio encontrado nos ensaios foi de $30 \mathrm{GPa}$.

Do estudo da resistência efetiva da argamassa projetada, pôde-se tirar uma indicação desse valor, que consistiu num aspecto significativo do trabalho. Com este estudo tornou-se possível estimar a resistência efetiva da argamassa projetada, a partir de ensaios de compressão de corpos-de-prova cilíndricos.

Dos resultados encontrados, apresentados e discutidos no capítulo 3, verificou-se que a resistência efetiva à compressão da argamassa projetada é cerca de $80 \%$ da resistência de corpos-de-prova cilíndricos de $10 \mathrm{~cm}$ x $20 \mathrm{~cm}$, moldados conforme a Norma Brasileira.

Essa estimativa da resistência efetiva foi fundamental para $o$ prosseguimento dos estudos sobre o comportamento à flexão de elementos de seção tipo sanduíche.

\subsubsection{Vigas $T$}

Nos ensaios realizados nas vigas $\mathrm{T}$ de seção tipo sanduíche, procurou-se compreender melhor o comportamento à flexão desse tipo de elemento, verificandose a eficácia da ligação mesa-alma.

A seção tipo sanduíche proposta para a viga VT 02 demonstrou ser eficiente quanto à ligação mesa-alma, resistindo bem aos esforços de flexão.

Comparando-se os valores calculados com os experimentais, do momento de fissuração, do momento de ruptura e dos deslocamentos relativos ao ensaio de flexão das vigas, pôde-se verificar que, no cálculo de seções tipo sanduíche, podem 
ser utilizadas as mesmas hipóteses relativas ao concreto armado prescritas na NBR 6118. As nervuras laterais da mesa e o núcleo maciço implementado no modelo VT 02 foram os responsáveis para que o comportamento à flexão correspondesse ao de uma seção equivalente de concreto armado.

\subsubsection{Painéis}

Quanto aos ensaios de flexão realizados em painéis tipo sanduíche, com núcleo de EPS e faces executadas por projeção da argamassa, comprovou-se que as hipóteses utilizadas em concreto armado podem ser adotadas para o cálculo do momento de fissuração e dos deslocamentos, considerando no cálculo a uma seção maciça equivalente, determinada a partir da redução do momento de inércia da seção tipo sanduíche, multiplicando-se por um coeficiente $\mathrm{C}$, que leva em conta a perda de rigidez pela movimentação relativa entre as faces. Esse coeficiente deve ser determinado através de ensaios, para cada tipo de núcleo ou conector utilizado.

Para o caso estudado - núcleo de EPS e placas resistentes de argamassa projetada - pode-se utilizar os seguintes valores de C:

\begin{tabular}{l|l}
\hline Tipo de seção & $\begin{array}{l}\text { Coeficiente de redução do momento de } \\
\text { inércia (C) }\end{array}$ \\
\hline núcleo de EPS sem nervuras & 0,13 \\
\hline núcleo de EPS com nervuras & 0,28 \\
\hline
\end{tabular}

Em relação ao dimensionamento dos painéis com nervuras, pode-se adotar as mesmas hipóteses utilizadas para o concreto armado no estado limite último, considerando-se a seção completamente composta. Os valores dos momentos últimos encontrados experimentalmente foram ligeiramente maiores que os valores teóricos.

Para o painel tipo sanduíche sem nervuras, o valor teórico do momento último, calculado com as mesmas hipóteses mencionadas no parágrafo anterior, foi $24 \%$ menor do que o valor obtido experimentalmente. Para o dimensionamento desse tipo de seção, deve-se majorar o valor do momento de cálculo, a fim de levar em conta a movimentação relativa entre as faces.

Realizou-se ainda uma série de ensaios de compressão em painéis tipo sanduíche. Devido a algumas falhas ocorridas durante a execução dos ensaios, os resultados foram prejudicados, e sua análise não levou a resultados consistentes. Optou-se por apresentar esta parte do trabalho como anexo (ANEXO D). 


\subsubsection{Conclusões Gerais}

Os ensaios realizados comprovam um bom desempenho estrutural dos painéis tipo sanduíche. Acredita-se que o êxito já comprovado dessa técnica na construção de edificações possa ser estendido a obras de interesse social, transferindo todas as vantagens tecnológicas do sistema, trazendo mais uma alternativa em relação às técnicas construtivas tradicionais.

\subsection{SUGESTÕES PARA NOVAS PESQUISAS}

O estudo do comportamento à compressão de painéis tipo sanduíche é um tema que precisa ser melhor investigado, pois os ensaios realizados não proporcionaram conclusões consistentes. O aprofundamento nesse tema é de fundamental importância, para obter modelos de cálculo e de dimensionamento que melhor representem a realidade.

Estudos que comprovem a resistência efetiva da argamassa projetada são necessários, a fim de aferir os resultados já encontrados.

O material do núcleo pode ser constituído de inúmeros tipos, tornando-se necessário um estudo mais detalhado desses materiais, apontando suas características, disponibilidade, qualidades, defeitos e limitações de uso. Com isso pode-se levantar critérios para a escolha do material mais indicado para determinado uso.

Um estudo visando tipificar melhor as ligações dos elementos estruturais, utilizados em construções de infra-estrutura, com certeza contribuirá para um melhor desempenho desse tipo de sistema estrutural.

Questões sobre a durabilidade da argamassa projetada devem ser estudadas, verificando-se meios para amenizar os efeitos da retração.

Análises numéricas utilizando programas computacionais podem ser implementadas, comparando e aferindo os resultados encontrados nos ensaios. Esse estudo poderia dar maior confiabilidade aos resultados, podendo-se extrapolar as conclusões obtidas.

Por fim, um estudo comparativo de custo, entre o sistema proposto neste trabalho e sistemas em uso já consagrados, tornaria bastante abrangente o domínio do conhecimento sobre este assunto. 


\section{ANEXO A - DETERMINAÇÃO DO TRAÇO}

\section{PROCEDIMENTO EXPERIMENTAL PARA DETERMINAÇÃO DO TRAÇO}

Com relação à parte experimental, o primeiro passo foi fixar a resistência padrão da argamassa em $40 \mathrm{MPa}$, adotada em função do emprego destinado aos elementos (painéis autoportantes) a serem projetados e da durabilidade requerida pela estrutura, e propor o conceito de trabalhabilidade ideal para projeção, que se refere às propriedades (coesão, consistência e fluidez) da argamassa no estado fluido, que viabilizem a sua projeção.

Fixados esses parâmetros, trabalhou-se na determinação da relação cimento/agregado da argamassa a ser utilizada e do seu fator água/cimento $(\mathrm{a} / \mathrm{c})$. Como são muitas as variáveis envolvidas, esta fase do trabalho foi desenvolvida tomando-se por base estudos já realizados em laboratório, nos quais se pôde encontrar uma grande variedade de traços de argamassa já analisados. Com base nessas experiências anteriores, pôde-se limitar em muito o intervalo das proporções dos materiais.

\subsection{Materiais Empregados}

Tomando-se por base a bibliografia analisada, optou-se por trabalhar com os seguintes materiais:

- Cimento tipo ARI;

- Areia média;

- Superplastificante;

- Sílica ativa.

O cimento empregado foi o cimento Portland de alta resistência inicial CPV-ARI PLUS, marca Ciminas. Optou-se pelo uso de cimento tipo ARI, para que os resultados pudessem ser obtidos mais rapidamente, visto que os elementos podiam ser ensaiados aos sete dias, idade na qual esse tipo de cimento já atinge praticamente toda a sua resistência. 
Com relação aos agregados miúdos, utilizou-se areia natural quartzosa proveniente do Rio Mogi-Guaçu, cuja curva granulométrica a enquadra como areia média (módulo de finura $=2,50$ e $\rho=2,62 \mathrm{~g} / \mathrm{cm}^{3}$ ). Essa areia passou por um processo de peneiramento em malha de $5 \mathrm{~mm}$, para remoção e de matéria orgânica e outros materiais estranhos à amostra (torrões de terra e agregados graúdos), sem que esse processo pudesse descaracterizar a amostra. Segue na figura A1 a curva granulométrica da areia utilizada.

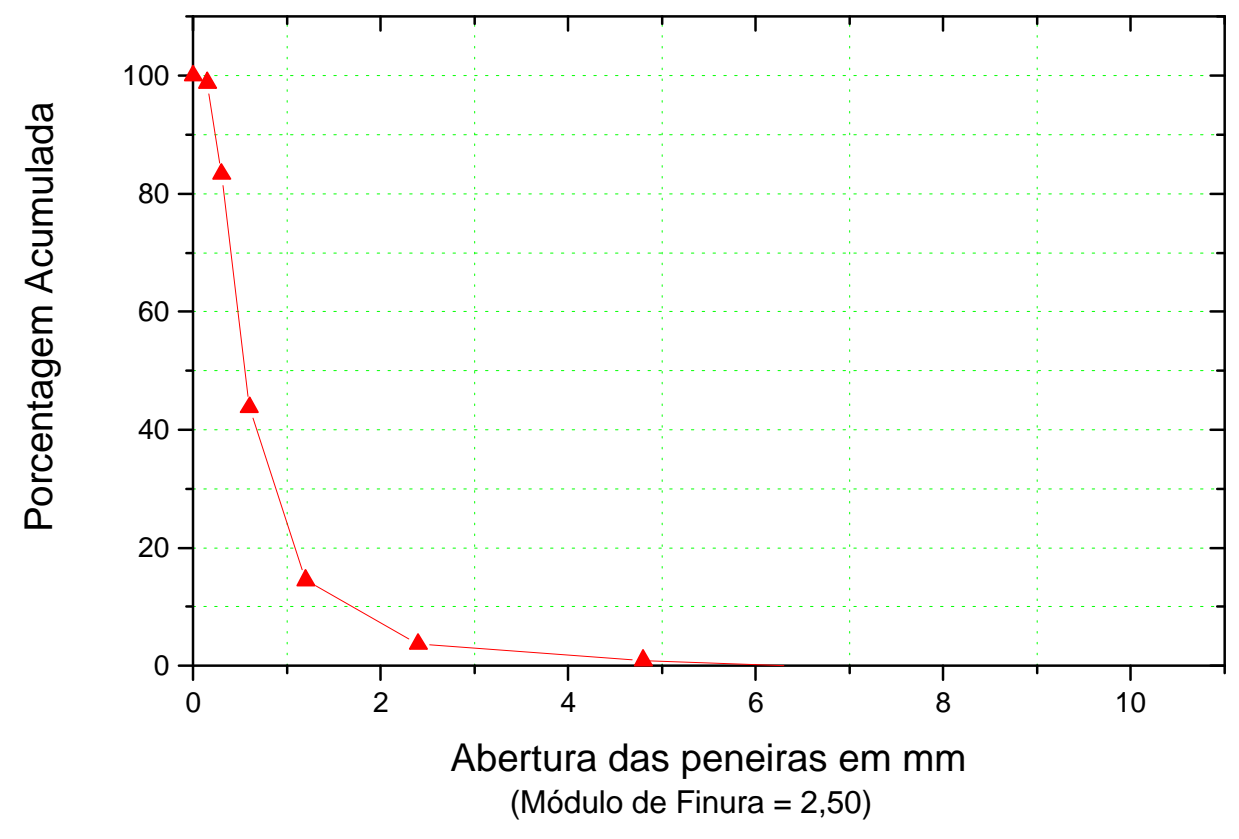

FIGURA A1 - CURVA GRANUlomÉTRICA DA AREIA Do Rio MoGI

Com relação aos demais materiais, optou-se por utilizar superplastificante marca Reax 3000 e sílica ativa marca Silmix. A opção de se utilizar superplastificantes deu-se pela necessidade de resistência relativamente elevada da argamassa e de baixos valores de retração por secagem. O uso de sílica ativa fez-se necessário para obtenção de argamassas coesas, com o objetivo de diminuir o índice de reflexão durante as projeções e melhorar a adesão da argamassa ao painel de projeção.

\subsection{Traços Estudados}

De acordo com os traços analisados encontrados na literatura, optou-se por estudar as seguintes variações de traços:

- Relação cimento/agregado miúdo, variando de 1:2,5 a 1:4,0 em massa; 
- Uso de superplastificante na faixa de 0 a $2 \%$ da massa de cimento;

- Uso de sílica ativa na faixa de 0 a $15 \%$ da massa de cimento.

A quantidade de água de cada traço foi determinada empiricamente; levou-se em consideração a trabalhabilidade ideal ${ }^{\mathbf{1}}$ para projeção. Pequenas frações de água eram adicionadas até o ponto em que essa trabalhabilidade ideal era atingida, sendo determinada subjetivamente através da experiência dos laboratoristas. Atingido esse ponto, determinava-se a quantidade de água adicionada através de pesagem ${ }^{2}$.

O procedimento experimental de determinação do traço padrão foi dividido em quatro séries de ensaios, detalhadamente descritos a seguir. Os resultados obtidos para cada série estão apresentados na tabela 3.1.

\subsection{Ensaios Realizados}

Para a análise das propriedades das argamassas recorreu-se a ensaios padronizados pela Associação Brasileira de Normas Técnicas. Os ensaios utilizados foram os seguintes:

- Concreto - Determinação da consistência pelo espalhamento do tronco de cone NBR 9609;

- Ensaio de compressão de corpos-de-prova cilíndricos de concreto - NBR5739;

- Concreto - Determinação do módulo de deformação estática e diagrama tensãodeformação - NBR 8522.

\section{SÉRIES DE ENSAIOS}

\subsection{Primeira Série de Ensaios}

Para a primeira série de ensaios foram executados alguns traços, utilizandose as relações cimento/agregado 1:2,5; 1:3; e 1:4; sem utilização de superplastificante nem de sílica ativa.

Foram moldados três corpos-de-prova cilíndricos de $5 \mathrm{~cm} \times 10 \mathrm{~cm}$, para cada traço.

A quantidade de água para cada mistura era tomada em função de uma trabalhabilidade ideal para se projetar a argamassa, conforme exposto anteriormente.

\footnotetext{
${ }^{1}$ A trabalhabilidade ideal da argamassa refere-se a uma mistura que possa ser projetada manualmente.

${ }^{2}$ É importante ressaltar que todas as proporções aqui apresentadas se referem a traços em massa.
} 
O traço 1:4 foi abandonado já nessa série de ensaios, devido aos baixos valores de resistência apresentados.

\subsection{Segunda Série de Ensaios}

A segunda série de ensaios foi realizada com os mesmos traços utilizados na série anterior (com exceção do traço 1:4), adicionando-se superplastificante, com o intuito de diminuir a quantidade de água e, consequentemente, aumentar a resistência das amostras à compressão.

Foram moldados três corpos-de-prova cilíndricos de $5 \mathrm{~cm} \times 10 \mathrm{~cm}$, para cada traço.

Os resultados dos ensaios à compressão axial mostraram que o traço 1:3 já fornecia a resistência desejada. Portanto, o traço 1:2,5 foi abandonado a partir dessa série de ensaios, por causa do seu alto consumo de cimento, o que aumenta a retração por secagem.

\subsection{Terceira Série de Ensaios}

Com a relação cimento/agregado definida em 1:3, realizaram-se ainda alguns ensaios, adicionando-se a sílica ativa para melhorar algumas características da argamassa, especialmente sua coesão. Utilizaram-se proporções de sílica ativa de $5 \%, 10 \%$ e $15 \%$ em relação à massa de cimento.

Foram moldados três corpos-de-prova cilíndricos de $5 \mathrm{~cm}$ x $10 \mathrm{~cm}$, para cada traço. Verificou-se que a sílica ativa adicionada à mistura melhora sobremaneira a coesão da argamassa, apresentando ainda um ganho de resistência.

\subsection{Quarta Série de Ensaios}

Com base nos resultados obtidos anteriormente, optou-se por testar traços com $10 \%$ e $15 \%$ de sílica ativa e $2 \%$ de superplastificante. Em um dos traços foi removida a quantidade de cimento equivalente à massa de sílica ativa adicionada à mistura, mas essa idéia foi abandonada por causa da baixa resistência à compressão atingida. Nos outros traços trabalhou-se em busca de relações a/c que fornecessem boa trabalhabilidade.

Foram moldados três corpos-de-prova cilíndricos de $5 \mathrm{~cm}$ x $10 \mathrm{~cm}$ para cada traço.

Os dados obtidos para todos os traços testados estão apresentados na tabela A1. 
TABELA A1 - Resultados das Séries de Ensaios

\begin{tabular}{|c|c|c|c|c|c|}
\hline Traço & $\begin{array}{c}\text { Fator } \\
\text { a/c }\end{array}$ & $\begin{array}{c}\text { Sílica Ativa } \\
\text { (SA) }\end{array}$ & $\begin{array}{c}\text { Superplastificante } \\
\text { (SP) }\end{array}$ & $\begin{array}{c}\text { Consistência } \\
(\mathbf{m m})\end{array}$ & $\begin{array}{c}\text { Resistência } \\
(\mathbf{M P a})\end{array}$ \\
\hline \multicolumn{7}{|c|}{ Primeira Série de Ensaios } \\
\hline $1: 4$ & 0,87 & - & - & 297 & 18,5 \\
\hline $1: 2$ & 0,56 & - & - & 265 & 40,5 \\
\hline $1: 3$ & 0,66 & - & - & 293 & 29,0 \\
\hline \multicolumn{7}{|c|}{ Segunda Série de Ensaios } \\
\hline $1: 2,5$ & 0,45 & - & $2,0 \%$ & 300 & 53,0 \\
\hline $1: 2,5$ & 0,45 & - & $1,5 \%$ & 250 & 50,9 \\
\hline $1: 3$ & 0,53 & - & $1,5 \%$ & 259 & 43,1 \\
\hline \multicolumn{7}{|c|}{ Terceira Série de Ensaios } \\
\hline $1: 3$ & 0,59 & $5,0 \%$ & - & 195 & 31,4 \\
\hline $1: 3$ & 0,65 & $10,0 \%$ & - & 195 & 29,0 \\
\hline $1: 3$ & 0,68 & $15,0 \%$ & - & 201 & 31,6 \\
\hline \multicolumn{7}{|c|}{ Quarta Série de Ensaios } \\
\hline $1: 3 *$ & 0,63 & $15,0 \%$ & $2,0 \%$ & 220 & 27,7 \\
\hline $1: 3$ & n.d. & $15,0 \%$ & $2,0 \%$ & 270 & 32,1 \\
\hline $1: 3$ & 0,51 & $10,0 \%$ & $2,0 \%$ & 190 & 48,7 \\
\hline $1: 3$ & 0,60 & $15,0 \%$ & $2,0 \%$ & 200 & 37,6 \\
\hline $1: 3$ & 0,47 & $10,0 \%$ & $2,0 \%$ & 165 & 55,4 \\
\hline
\end{tabular}

Observações:

"Para este traço, a quantidade adicionada de sílica ativa foi igual à quantidade removida de cimento; n.d. - não determinado.

Com base nos dados da tabela A1 adotou-se como traço padrão o seguinte: $1: 3+\operatorname{SP}(2 \%)+\mathrm{SA}(10 \%)^{3}$. Esse traço foi escolhido pelo fato de, além de proporcionar adequada resistência à compressão e trabalhabilidade satisfatória à projeção, foi um dos que apresentou o menor potencial de retração por secagem, decorrente de seu baixo consumo de cimento e de água.

Foram também realizadas projeções com esse traço, usando-se a caneca de projeção, verificando-se a eficiência dessa técnica de projeção para o traço escolhido.

\footnotetext{
${ }^{3} \mathrm{SA}=$ Sílica Ativa; $\mathrm{SP}=$ Superplastificante.
} 


\section{ANEXO B - CRITÉRIOS DE TRATAMENTO DOS RESULTADOS}

\section{CRITÉRIO DE CHAUVENET}

\subsection{Generalidades}

O critério aqui apresentado para tratamento estatístico de um conjunto de dados tem por objetivo eliminar valores não representativos de amostras pequenas (menores que 50 elementos). Além disso, tem a vantagem de poder trabalhar conjuntamente dados com valores numericamente diferentes, uma vez que todo o cálculo é baseado na relação entre valores pontuais e a média da amostra, reduzindo todos os dados a variações percentuais da média amostral.

\subsection{Corpos-de-Prova Cilíndricos - Generalidades}

As pastilhas extraídas de corpos-de-prova cilíndricos constituem três amostras diferentes: A, B e C. Isto ocorre porque cada conjunto (A, B e C) foi executado com um fator a/c diferente, apesar do uso do mesmo traço (o traço padrão), o que se traduz em valores substancialmente diferentes para a tensão de ruptura.

As amostras A e B possuem 12 elementos cada, e a amostra C, 21, totalizando 45 elementos.

\subsection{Painéis Projetados - Generalidades}

As pastilhas extraídas dos painéis projetados constituem um único grande conjunto, pois todos os painéis foram executados com o mesmo traço (o traço padrão) e o mesmo fator a/c. Contudo, foram divididos em painéis, a saber, 1, 2 e 3, com 15 pastilhas cada um, totalizando 45 elementos.

\subsection{Tabelas I e III}

\subsubsection{Traço/Painel}

Indica os traços (A, B ou C) ou o painel (1, 2 ou 3) de onde foram removidas as pastilhas. 


\subsubsection{Amostra}

Refere-se às pastilhas de Topo, Meio e Base, posição da qual foram extraídas do corpo-de-prova de origem.

\subsubsection{Qu}

Valor da tensão de ruptura para cada pastilha, medida em MPa.

\subsubsection{Qm}

Média amostral para as pastilhas de topo, meio e base, em cada um dos conjuntos A, B e C, ou para cada painel, 1, 2 e 3.

\subsubsection{Qu/Qm}

Relação entre cada valor de Qu e sua respectiva média amostral Qm. Esta relação reduz os valores de tensão de ruptura de cada pastilha (e cada relação a/c) a variações percentuais em relação à média amostral, o que permite um tratamento conjunto de dados substancialmente diferentes.

\subsubsection{Desvio padrão}

O valor de s, encontrado no fim da tabela, é o desvio padrão da relação $\mathrm{Qu} / \mathrm{Qm}$.

\subsubsection{C45}

$\mathrm{O}$ valor $\mathrm{C} 45$, em primeiro lugar, recebe esse nome porque se refere a um conjunto total de 45 elementos. $\mathrm{O}$ valor apresentado nesta célula é o valor s $+0,05$. A partir desse valor, serão eliminados os valores de Qu que se distanciarem da média mais que $5 \%$ do desvio padrão.

\subsection{8 $1+\mathrm{C} 45$}

Todo valor de Qu que for maior que $1+$ C45 será eliminado.

\subsubsection{1 - $\mathrm{C45}$}

Todo valor de Qu que for menor que 1 - C45 também será eliminado.

Em cada iteração, os cálculos são refeitos, sendo que na posição referente a cada valor eliminado aparece a mensagem FALSO. Portanto, os cálculos seguem sem esses valores, fazendo com que o conjunto mantenha elementos cada vez mais 
uniformes, como evidenciado pelos valores decrescentes do desvio padrão (s) após cada iteração.

O número de iterações fixado foi de três, sendo obrigatório interromper o processo, mesmo que ainda haja valores a serem descartados.

Abaixo da tabela do critério de Chauvenet são encontrados quadros que apresentam os resultados parciais e finais obtidos para cada conjunto. Esses quadros serão discutidos a seguir.

\subsection{Corpos-de-Prova Cilíndricos - Resultados Parciais (Tabela I)}

Para o conjunto amostral de pastilhas extraídas de corpos-de-prova cilíndricos, os resultados parciais dessa análise estatística estão esclarecidos a seguir:

\subsubsection{Média}

Refere-se à média dos valores de tensão de ruptura que não foram descartados, para cada conjunto de amostras (A, B e C).

\subsubsection{Desvio Padrão}

Refere-se ao desvio padrão dos valores de tensão de ruptura que não foram descartados, para cada conjunto de amostras (A, B e C).

\subsubsection{Coeficiente de Variação}

Relação Média / Desvio Padrão.

\subsubsection{Corpo-de-Prova}

Refere-se à tensão média de ruptura dos corpos-de-prova cilíndricos, tidos com valores de referência.

\subsubsection{Fator de Forma}

Este é o resultado procurado, que indica a porcentagem de tensão necessária à ruptura das pastilhas, tendo como valor de referência a tensão de ruptura dos corposde-prova. 


\subsection{Corpos-de-Prova Cilíndricos - Resultados Finais (Tabela I)}

Para as pastilhas extraídas de corpos-de-prova cilíndricos, os resultados finais obtidos dessa análise estatística estão esclarecidos em seguida:

\subsubsection{Desvio Padrão}

Refere-se à média dos desvios padrões dos valores de tensão de ruptura que não foram descartados, para o conjunto total de amostras.

\subsubsection{Coeficiente de Variação Médio}

Média da relação Média / Desvio Padrão, para o conjunto total de amostras.

\subsubsection{Fator de Forma}

Este é o resultado final procurado, que indica a porcentagem de tensão necessária à ruptura das pastilhas, tendo como valor de referência a tensão de ruptura dos corpos-de-prova. É a média dos fatores de forma obtidos anteriormente.

\subsection{Painéis Projetados - Resultados Parciais (Tabela III)}

Para as pastilhas extraídas dos painéis projetados, os resultados parciais obtidos estão esclarecidos nos subitens seguintes.

\subsubsection{Média}

Refere-se à média dos valores de tensão de ruptura que não foram descartados, para cada painel $(1,2$ e 3$)$.

\subsubsection{Desvio Padrão}

Refere-se ao desvio padrão dos valores de tensão de ruptura que não foram descartados, para cada painel (1, 2 e 3$)$.

\subsubsection{Coeficiente de Variação}

Relação Média / Desvio Padrão.

\subsection{Painéis Projetados - Resultados Finais (Tabela III)}

Para as pastilhas extraídas dos painéis projetados, as informações encontramse a seguir. 


\subsubsection{Média}

Refere-se à média de tensão de ruptura média para cada painel (1, 2 e 3$)$.

\subsubsection{Desvio Padrão}

Refere-se à média dos desvios padrões dos valores de tensão de ruptura que não foram descartados, para os painéis (1, 2 e 3$)$.

\subsubsection{Coeficiente de Variação Médio}

Média da relação Média / Desvio Padrão, para os painéis (1, 2 e 3).

\section{DESCLASSIFICAÇÃO DAS PASTILHAS DEFEITUOSAS OU NÃO- REPRESENTATIVAS}

\subsection{Generalidades}

Este é um critério subjetivo, baseado em análise crítica e visual das amostras. Consiste basicamente em desclassificar os elementos que apresentaram alguma imperfeição física, traduzindo-se em faces não planas ou não paralelas, ou que tenham apresentado algum problema durante a ruptura. Foram também desclassificados os elementos que apresentaram valores extremamente altos para a tensão de ruptura.

\subsection{Tabela II e IV}

\subsubsection{Traço/Painel}

Indica os traços (A, B ou C) ou o painel(1, 2 ou 3) de onde foram removidas as pastilhas.

\subsubsection{Amostra}

Refere-se às pastilhas de Topo, Meio e Base, posição da qual foram extraídas do corpo-de-prova de origem.

\subsubsection{Qu}

Valor da tensão de ruptura, medida em MPa, para cada pastilha. 


\subsubsection{Qm}

Média amostral para as pastilhas de topo, meio e base, em cada um dos conjuntos A, B e C, ou para cada painel, 1, 2 e 3.

Após a desclassificação das pastilhas defeituosas ou não-representativas, calcula-se uma nova média amostral. Como esse processo não é iterativo, basta um passo para a obtenção das médias amostrais.

Abaixo da tabela deste critério são encontrados quadros que apresentam os resultados parciais e finais, obtidos para cada conjunto. Esses quadros serão discutidos a seguir.

\subsection{Corpos-de-Prova Cilíndricos - Resultados Parciais (Tabela II)}

Para o conjunto amostral de pastilhas extraídas de corpos-de-prova cilíndricos, os resultados parciais dessa análise estatística estão esclarecidos em seguida.

\subsubsection{Média}

Refere-se à média dos valores de tensão de ruptura que não foram descartados, para cada conjunto de amostras (A, B e C).

\subsubsection{Desvio Padrão}

Refere-se ao desvio padrão dos valores de tensão de ruptura que não foram descartados, para cada conjunto de amostras (A, B e C).

\subsubsection{Coeficiente de Variação}

Relação Média / Desvio Padrão.

\subsubsection{Corpo-de-Prova}

Refere-se à tensão média de ruptura dos corpos-de-prova cilíndricos, tidos com valores de referência.

\subsubsection{Fator de Forma}

Este é o resultado procurado, que indica a porcentagem de tensão necessária à ruptura das pastilhas, tendo como valor de referência a tensão de ruptura dos corposde-prova. 


\subsection{Corpos-de-Prova Cilíndricos - Resultados Finais (Tabela II)}

Para as pastilhas extraídas de corpos-de-prova cilíndricos, os resultados finais estão esclarecidos nos subitens seguintes.

\subsubsection{Desvio Padrão}

Refere-se à média dos desvios padrões dos valores de tensão de ruptura que não foram descartados, para as amostras (A, B e C).

\subsubsection{Coeficiente de Variação Médio}

Média da relação Média / Desvio Padrão para as amostras (A, B e C).

\subsubsection{Fator de Forma}

Este é o resultado final procurado, que indica a porcentagem de tensão necessária à ruptura das pastilhas, tendo como valor de referência a tensão de ruptura dos corpos-de-prova. É a média dos fatores de forma obtidos anteriormente.

\subsection{Painéis Projetados - Resultados Parciais (Tabela IV)}

Para as pastilhas extraídas dos painéis projetados, as informações sobre os resultados parciais encontram-se a seguir.

\subsubsection{Média}

Refere-se à média dos valores de tensão de ruptura que não foram descartados, para cada painel $(1,2$ e 3$)$.

\subsubsection{Desvio Padrão}

Refere-se ao desvio padrão dos valores de tensão de ruptura que não foram descartados, para cada painel (1, 2 e 3$)$.

\subsubsection{Coeficiente de Variação}

Relação Média / Desvio Padrão.

\subsection{Painéis Projetados - Resultados Finais (Tabela IV)}

Para as pastilhas extraídas dos painéis projetados, os resultados finais obtidos dessa análise estatística estão esclarecidos nos subitens seguintes. 


\subsubsection{Média}

Refere-se à média de tensão de ruptura média para cada painel (1, 2 e 3).

\subsubsection{Desvio Padrão}

Refere-se à média dos desvios padrões dos valores de tensão de ruptura que não foram descartados, para os painéis (1, 2 e 3$)$.

\subsubsection{Coeficiente de Variação Médio}

Média da relação Média / Desvio Padrão, para os painéis (1, 2 e 3). 


\section{TABELAS}

\section{Tabela I - Critério de Chauvenet}

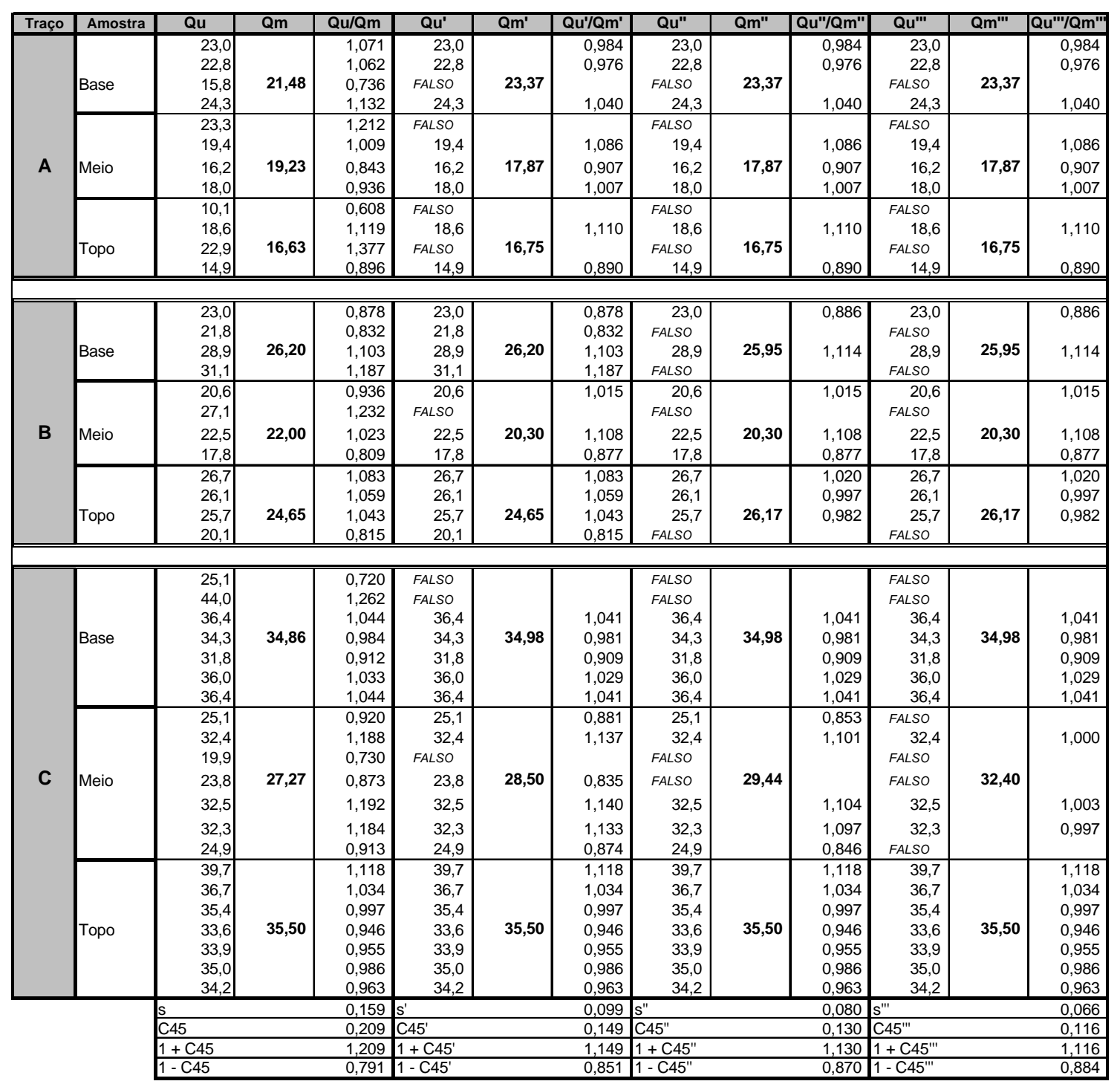

\begin{tabular}{|lr|}
\hline Resultado Parcial - & Amostra A \\
\hline Média & 19,7 \\
Desvio Padrão & 3,404 \\
Coef. de Variação & 0,17 \\
Corpo-de-prova & 32,1 \\
Fator de Forma & $\mathbf{0 , 6 1 2}$ \\
\hline Resultado Parcial - Amostra B \\
\hline Média & 23,9 \\
Desvio Padrão & 3,621 \\
Coef. de Variação & 0,15 \\
Corpo-de-prova & 37,6 \\
Fator de Forma & $\mathbf{0 , 6 3 6}$ \\
\hline Resultado Parcial - Amostra C \\
\hline Média & 34,7 \\
Desvio Padrão & 2,132 \\
Coef. de Variação & 0,06 \\
Corpo-de-prova & $\mathbf{5 5 , 4}$ \\
Fator de Forma & $\mathbf{0 , 6 2 6}$ \\
\hline
\end{tabular}

\begin{tabular}{|lr|}
\hline \multicolumn{2}{|c|}{ Resultado Final } \\
\hline Desvio Padrão Médio & 3,052 \\
Coef. de Variação Mé & 0,13 \\
Fator de Forma & $\mathbf{0 , 6 2 5}$ \\
\hline
\end{tabular}




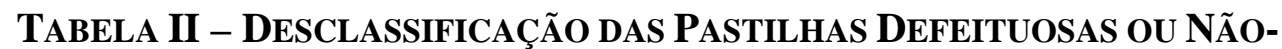
REPRESENTATIVAS

\begin{tabular}{|c|c|c|c|c|c|}
\hline Traço & Amostra & $\mathrm{Qu}$ & $\overline{Q m}$ & $\overline{Q u^{\prime}}$ & $Q^{\prime}$ \\
\hline \multirow{3}{*}{ A } & Base & \begin{tabular}{l|}
23,0 \\
22,8 \\
15,8 \\
24,3
\end{tabular} & 21,48 & $\begin{array}{c}23,0 \\
22,8 \\
\text { FALSO } \\
24,3\end{array}$ & 23,37 \\
\hline & Meio & $\begin{array}{l}23,3 \\
19,4 \\
16,2 \\
18,0\end{array}$ & 19,23 & $\begin{array}{l}23,3 \\
19,4 \\
16,2 \\
18,0\end{array}$ & 19,23 \\
\hline & Topo & \begin{tabular}{l|}
10,1 \\
18,6 \\
22,9 \\
14,9 \\
\end{tabular} & 16,63 & $\begin{array}{c}\text { FALSO } \\
18,6 \\
22,9 \\
\text { FALSO } \\
\end{array}$ & 20,75 \\
\hline \multirow{3}{*}{ B } & Base & $\begin{array}{l}23,0 \\
21,8 \\
28,9 \\
31,1\end{array}$ & 26,20 & $\begin{array}{l}23,0 \\
21,8 \\
28,9 \\
31,1\end{array}$ & 26,20 \\
\hline & Meio & $\begin{array}{l}20,6 \\
27,1 \\
22,5 \\
17,8\end{array}$ & 22,00 & $\begin{array}{r}20,6 \\
27,1 \\
22,5 \\
\text { FALSO }\end{array}$ & 23,40 \\
\hline & Topo & $\begin{array}{l}26,7 \\
26,1 \\
25,7 \\
20,1 \\
\end{array}$ & 24,65 & $\begin{array}{l}26,7 \\
26,1 \\
25,7 \\
20,1 \\
\end{array}$ & 24,65 \\
\hline \multirow{3}{*}{ C } & Base & $\begin{array}{l}25,1 \\
44,0 \\
36,4 \\
34,3 \\
31,8 \\
36,0 \\
36,4\end{array}$ & 34,86 & $\begin{array}{r}\text { FALSO } \\
\text { FALSO } \\
36,4 \\
34,3 \\
31,8 \\
36,0 \\
36,4\end{array}$ & 34,98 \\
\hline & Meio & $\begin{array}{l}25,1 \\
32,4 \\
19,9 \\
23,8 \\
32,5 \\
32,3 \\
24,9\end{array}$ & 27,27 & $\begin{array}{c}\text { FALSO } \\
32,4 \\
\text { FALSO } \\
\text { FALSO } \\
32,5 \\
32,3 \\
\text { FALSO }\end{array}$ & 32,40 \\
\hline & Topo & $\begin{array}{l}39,7 \\
36,7 \\
35,4 \\
33,6 \\
33,9 \\
35,0 \\
34,2\end{array}$ & 35,50 & $\begin{array}{r}\text { FALSO } \\
36,7 \\
35,4 \\
33,6 \\
33,9 \\
35,0 \\
34,2\end{array}$ & 34,80 \\
\hline
\end{tabular}

\begin{tabular}{|lr|}
\hline Resultado Parcial - & Amostra A \\
\hline Média & 20,94 \\
Desvio Padrão & 2,902 \\
Coef. de Variação & 0,14 \\
Corpo-de-prova & 32,1 \\
Fator de Forma & $\mathbf{0 , 6 5 2}$ \\
\hline Resultado Parcial - & Amostra B \\
\hline Média & 24,9 \\
Desvio Padrão & 3,537 \\
Coef. de Variação & 0,14 \\
Corpo-de-prova & 37,6 \\
Fator de Forma & $\mathbf{0 , 6 6 2}$ \\
\hline Resultado Parcial - Amostra C \\
\hline Média & 34,4 \\
Desvio Padrão & 1,685 \\
Coef. de Variação & 0,05 \\
Corpo-de-prova & 55,4 \\
Fator de Forma & $\mathbf{0 , 6 2 0}$ \\
\hline
\end{tabular}

Resultado Final Desvio Padrão Médio Coef. de Variação Mé Fator de Forma 
TAbela III - Critério de Chauvenet

\begin{tabular}{|c|c|c|c|c|c|c|c|c|c|c|c|c|}
\hline Painel & Qu & Qm & $\mathrm{Qu} / \mathrm{Qm}$ & $Q u^{\prime}$ & $\mathrm{Qm}^{\prime}$ & $\mathrm{Qu}^{\prime} / \mathbf{Q m}^{\prime}$ & Qu" & $Q^{\prime \prime}$ & $\mathrm{Qu}^{\prime \prime} / \mathrm{Qm}^{\prime \prime}$ & $\mathrm{Qu}^{\prime \prime \prime}$ & $\mathrm{Qm}^{\prime \prime \prime}$ & $\mathrm{Qu}^{\prime \prime \prime} / \mathrm{Qm}^{\prime \prime \prime}$ \\
\hline \multirow{15}{*}{1} & 30,8 & \multirow{15}{*}{31,73} & 0,971 & 30,8 & \multirow{15}{*}{30,50} & \multirow[t]{2}{*}{1,010} & \multirow{7}{*}{$\begin{array}{c}30,8 \\
\text { FALSO } \\
32,2 \\
34,3 \\
\text { FALSO } \\
29,7 \\
30,6\end{array}$} & \multirow{15}{*}{30,50} & \multirow[t]{2}{*}{1,010} & 30,8 & \multirow{15}{*}{30,50} & 1,010 \\
\hline & 38,4 & & 1,210 & FALSO & & & & & & FALSO & & \multirow[b]{2}{*}{1,056} \\
\hline & 32,2 & & 1,015 & 32,2 & & \multirow{2}{*}{$\begin{array}{l}1,056 \\
1,125\end{array}$} & & & 1,056 & 32,2 & & \\
\hline & 34,3 & & 1,081 & 34,3 & & & & & 1,125 & 34,3 & & 1,125 \\
\hline & 41,0 & & 1,292 & FALSO & & & & & & FALSO & & \\
\hline & 29,7 & & 0,936 & 29,7 & & 0,974 & & & 0,974 & 29,7 & & 0,974 \\
\hline & 30,6 & & 0,964 & 30,6 & & 1,003 & & & 1,003 & 30,6 & & 1,003 \\
\hline & 34,2 & & 1,078 & 34,2 & & 1,121 & 34,2 & & 1,121 & 34,2 & & 1,121 \\
\hline & 28,3 & & 0,892 & 28,3 & & 0,928 & 28,3 & & 0,928 & 28,3 & & 0,928 \\
\hline & 27,3 & & 0,860 & 27,3 & & 0,895 & 27,3 & & 0,895 & 27,3 & & 0,895 \\
\hline & 34,4 & & 1,084 & 34,4 & & 1,128 & 34,4 & & 1,128 & 34,4 & & 1,128 \\
\hline & 28,3 & & 0,892 & 28,3 & & 0,928 & 28,3 & & 0,928 & 28,3 & & 0,928 \\
\hline & 28,5 & & 0,898 & 28,5 & & 0,934 & 28,5 & & 0,934 & 28,5 & & 0,934 \\
\hline & 30,6 & & 0,964 & 30,6 & & 1,003 & 30,6 & & 1,003 & 30,6 & & 1,003 \\
\hline & 27,3 & & 0,860 & 27,3 & & 0,895 & 27,3 & & 0,895 & 27,3 & & 0,895 \\
\hline Painel & $\overline{Q u}$ & $\overline{Q m}$ & Qu/Qm & $\overline{Q u^{\prime}}$ & $\mathrm{Qm}^{\prime}$ & Qu'/Qm' & Qu" & Qm" & Qu"/Qm" & Qu'"I & $\mathrm{Qm}^{\prime \prime \prime}$ & $\mathrm{Qu}^{\prime \prime \prime} / \mathrm{Qm}^{\prime \prime \prime}$ \\
\hline & 28,5 & & 0,963 & 28,5 & & 0,999 & 28,5 & & 1,030 & 28,5 & & 1,050 \\
\hline & 35,2 & & 1,189 & 35,2 & & 1,234 & FALSO & & & FALSO & & \\
\hline & 31,9 & & 1,078 & 31,9 & & 1,118 & 31,9 & & 1,153 & FALSO & & \\
\hline & 27,8 & & 0,939 & 27,8 & & 0,975 & 27,8 & & 1,005 & 27,8 & & 1,024 \\
\hline & 25,9 & & 0,875 & 25,9 & & 0,908 & 25,9 & & 0,936 & 25,9 & & 0,954 \\
\hline & 28,2 & & 0,953 & 28,2 & & 0,989 & 28,2 & & 1,019 & 28,2 & & 1,039 \\
\hline & 26,9 & & 0,909 & 26,9 & & 0,943 & 26,9 & & 0,972 & 26,9 & & 0,991 \\
\hline 2 & 33,9 & 29,60 & 1,145 & 33,9 & 28,53 & 1,188 & FALSO & 27,67 & & FALSO & 27,14 & \\
\hline & 39,8 & & 1,345 & FALSO & & & FALSO & & & FALSO & & \\
\hline & 24,2 & & 0,818 & 24,2 & & 0,848 & FALSO & & & FALSO & & \\
\hline & 23,0 & & 0,777 & FALSO & & & FALSO & & & FALSO & & \\
\hline & 26,0 & & 0,878 & 26,0 & & 0,911 & 26,0 & & 0,940 & 26,0 & & 0,958 \\
\hline & 27,8 & & 0,939 & 27,8 & & 0,975 & 27,8 & & 1,005 & 27,8 & & 1,024 \\
\hline & 26,0 & & 0,878 & 26,0 & & 0,911 & 26,0 & & 0,940 & 26,0 & & 0,958 \\
\hline & 38,9 & & 1,314 & FALSO & & & FALSO & & & FALSO & & \\
\hline
\end{tabular}

\begin{tabular}{|c|c|c|c|c|c|c|c|c|c|c|c|c|}
\hline Painel & Qu & Qm & $\mathrm{Qu} / \mathrm{Qm}$ & $Q^{\prime}$ & $Q^{\prime}$ & $\mathrm{Qu}^{\prime} / \mathrm{Qm}^{\prime}$ & Qu" & Qm" & Qu"/Qm" & Qu'" & Qm"' & $Q^{\prime \prime \prime} / Q^{\prime \prime \prime}$ \\
\hline \multirow{19}{*}{3} & 24,2 & \multirow{15}{*}{28,05} & 0,863 & 24,2 & \multirow{15}{*}{27,28} & 0,887 & 24,2 & \multirow{15}{*}{26,82} & 0,902 & 24,2 & \multirow{15}{*}{26,05} & \multirow{8}{*}{$\begin{array}{l}0,929 \\
1,052 \\
0,941 \\
1,136\end{array}$} \\
\hline & 27,4 & & 0,977 & 27,4 & & 1,004 & 27,4 & & 1,022 & 27,4 & & \\
\hline & 24,5 & & 0,873 & 24,5 & & 0,898 & 24,5 & & 0,914 & 24,5 & & \\
\hline & 29,6 & & 1,055 & 29,6 & & 1,085 & 29,6 & & 1,104 & 29,6 & & \\
\hline & 33,3 & & 1,187 & 33,3 & & 1,221 & FALSO & & & FALSO & & \\
\hline & 25,1 & & 0,895 & 25,1 & & 0,920 & 25,1 & & 0,936 & 25,1 & & \\
\hline & 26,1 & & 0,930 & 26,1 & & 0,957 & 26,1 & & 0,973 & 26,1 & & \\
\hline & 30,9 & & 1,101 & 30,9 & & 1,133 & 30,9 & & 1,152 & FALSO & & \\
\hline & 24,8 & & 0,884 & 24,8 & & 0,909 & 24,8 & & 0,925 & 24,8 & & 0,952 \\
\hline & 25,1 & & 0,895 & 25,1 & & \multirow[t]{2}{*}{0,920} & 25,1 & & 0,936 & 25,1 & & 0,964 \\
\hline & 38,9 & & 1,387 & FALSO & & & FALSO & & & FALSO & & \\
\hline & 25,6 & & 0,913 & 25,6 & & 0,938 & 25,6 & & 0,955 & 25,6 & & 0,983 \\
\hline & 28,1 & & 1,002 & 28,1 & & 1,030 & 28,1 & & 1,048 & 28,1 & & 1,079 \\
\hline & 26,0 & & 0,927 & 26,0 & & 0,953 & 26,0 & & 0,970 & 26,0 & & 0,998 \\
\hline & 31,2 & & 1,112 & 31,2 & & 1,144 & 31,2 & & 1,164 & FALSO & & \\
\hline & \multicolumn{2}{|l|}{ s } & 0,147 & \multicolumn{2}{|l|}{$\mathrm{s}^{\prime}$} & 0,101 & s" & & 0,081 & \multicolumn{2}{|l|}{ s"' } & 0,067 \\
\hline & \multicolumn{2}{|l|}{ C45 } & 0,197 & \multicolumn{2}{|l|}{ C45' } & 0,151 & C45" & & 0,131 & \multicolumn{2}{|l|}{ C45"' } & 0,117 \\
\hline & \multirow{2}{*}{\multicolumn{2}{|c|}{\begin{tabular}{|l|}
$1+C 45$ \\
$1-C 45$
\end{tabular}}} & 1,197 & \multicolumn{2}{|l|}{$1+C 45^{\prime}$} & 1,151 & $1+C 45$ & & 1,131 & \multicolumn{2}{|l|}{$1+C 45^{\prime \prime}$} & 1,117 \\
\hline & & & 0,803 & 1-C45 & & 0,849 & 1-C45" & & 0,869 & \multicolumn{2}{|l|}{$1-C 45^{\prime \prime \prime}$} & 0,883 \\
\hline
\end{tabular}

\begin{tabular}{|lc|}
\hline \multicolumn{2}{|c|}{ Resultado Parcial - Painel 1 } \\
\hline Média & 30,5 \\
Desvio Padrão & 2,600 \\
Coef. de Variação & 0,09 \\
\hline \multicolumn{2}{|c|}{ Resultado Parcial - Painel 2 } \\
\hline Média & 27,1 \\
Desvio Padrão & 1,072 \\
Coef. de Variação & 0,04 \\
\hline \multicolumn{2}{|c|}{ Resultado Parcial - Painel 3 } \\
\hline Média & 26,0 \\
Desvio Padrão & 1,674 \\
Coef. de Variação & 0,06 \\
\hline
\end{tabular}

\begin{tabular}{|lr|}
\hline \multicolumn{2}{|c|}{ Resultado Final } \\
\hline Média & 27,9 \\
Desvio Padrão Médio & 1,782 \\
Coef. de Variação Médio & 0,06 \\
\hline
\end{tabular}


Tabela IV - DesclassificaÇão das Pastilhas defeituosas ou Não-

\section{REPRESENTATIVAS}

\begin{tabular}{|c|r|r|r|r|}
\hline Painel & \multicolumn{1}{|c|}{ Qu } & Qm & \multicolumn{1}{c|}{$\mathbf{Q u}^{\prime}$} & $\mathbf{Q m}^{\prime}$ \\
\hline & 30,8 & & 30,8 & \\
& 38,4 & & & \\
& 32,2 & & 32,2 & \\
& 34,3 & & 34,3 & \\
& 41,0 & & & \\
& 29,7 & & 29,7 & \\
& 30,6 & & 30,6 & \\
$\mathbf{1}$ & 34,2 & $\mathbf{3 1 , 7 3}$ & 34,2 & $\mathbf{3 1 , 0 8}$ \\
& 28,3 & & 28,3 & \\
& 27,3 & & & \\
& 34,4 & & 34,4 & \\
& 28,3 & & 28,3 & \\
& 28,5 & & 28,5 & \\
& 30,6 & & 30,6 & \\
\hline \hline
\end{tabular}

\begin{tabular}{|c|c|c|c|c|}
\hline Painel & $\overline{Q Q u}$ & $\overline{Q m}$ & $\overline{Q u^{\prime}}$ & 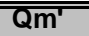 \\
\hline \multirow{15}{*}{2} & 28,5 & \multirow{15}{*}{29,60} & 28,5 & \multirow{15}{*}{29,25} \\
\hline & 35,2 & & & \\
\hline & 31,9 & & 31,9 & \\
\hline & 27,8 & & 27,8 & \\
\hline & 25,9 & & 25,9 & \\
\hline & 28,2 & & 28,2 & \\
\hline & 26,9 & & 26,9 & \\
\hline & 33,9 & & 33,9 & \\
\hline & 39,8 & & & \\
\hline & 24,2 & & & \\
\hline & 23,0 & & & \\
\hline & 26,0 & & 26,0 & \\
\hline & 27,8 & & 27,8 & \\
\hline & 26,0 & & 26,0 & \\
\hline & 38,9 & & 38,9 & \\
\hline
\end{tabular}

\begin{tabular}{|c|r|r|r|r|}
\hline Painel & \multicolumn{1}{|c|}{ Qu } & Qm & Qu' & Qm' \\
\hline \multirow{5}{*}{3} & 24,2 & & & \\
& 27,4 & & 27,4 & \\
& 24,5 & & & \\
& 29,6 & & 29,6 & \\
& 33,3 & & 33,3 & \\
& 25,1 & & 25,1 & \\
& 26,1 & & 26,1 & \\
& 30,9 & 28,05 & 30,9 & $\mathbf{2 8 , 9 4}$ \\
& 24,8 & & & \\
& 25,1 & & 25,1 & \\
& 38,9 & & 38,9 & \\
& 25,6 & & 25,6 & \\
& 28,1 & & 28,1 & \\
& 26,0 & & 26,0 & \\
& 31,2 & & 31,2 & \\
\hline \hline
\end{tabular}

\begin{tabular}{|lc|}
\hline \multicolumn{2}{|c|}{ Resultado Parcial - Painel 1 } \\
\hline Média & 31,1 \\
Desvio Padrão & 2,386 \\
Coef. de Variação & 0,08 \\
\hline \multicolumn{2}{|c|}{ Resultado Parcial - Painel 2 } \\
\hline Média & 29,3 \\
Desvio Padrão & 4,068 \\
Coef. de Variação & 0,14 \\
\hline \multicolumn{2}{|c|}{ Resultado Parcial - Painel 3 } \\
\hline Média & 28,9 \\
Desvio Padrão & 4,134 \\
Coef. de Variação & 0,14 \\
\hline
\end{tabular}

\begin{tabular}{|lr|}
\hline \multicolumn{2}{|c|}{ Resultado Final } \\
\hline Média & 29,8 \\
Desvio Padrão Médio & 3,530 \\
Coef. de Variação Médio & 0,12 \\
\hline
\end{tabular}




\section{ANEXO C - ENSAIO DO PROTÓTIPO DA VIGA T (VT 01)}

\section{DESCRIÇÃO DO MODELO}

A viga T tipo sanduíche - VT 01 foi idealizada de forma que tivesse o núcleo de EPS envolvido pela argamassa, conforme fig.C1.

As dimensões adotadas para a viga são mostradas na fig.C1. A largura da mesa é de $30 \mathrm{~cm}$ e a altura da alma, de $20 \mathrm{~cm}$. A espessura média das placas de argamassa é de $2,5 \mathrm{~cm}$ e a espessura do núcleo, de $5 \mathrm{~cm}$. A espessura total, tanto da mesa como da alma, é de $10 \mathrm{~cm}$. O comprimento da viga é de $300 \mathrm{~cm}$.
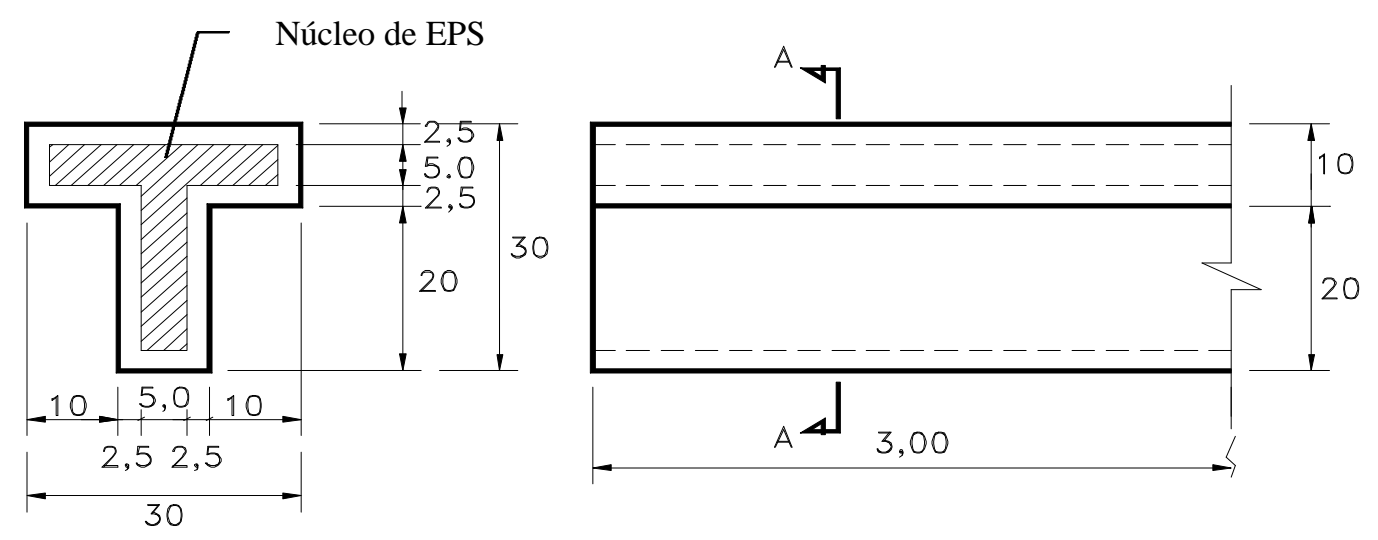

FIGURA C1 - DIMENSÕES DA VIGA T - MODELO VT 01

\section{MATERIAIS EMPREGADOS}

\subsection{Argamassa}

Para este modelo utilizou-se o Cimento Portland Comum (CP 32 - E), de marca Ribeirão. A argamassa tinha a relação cimento/agregado 1:2,5 e fator água/cimento 0,45. Utilizou-se ainda 1,5\% de superplastificante Reax $3000 \mathrm{em}$ relação à massa de cimento. A resistência média à compressão foi $\mathrm{f}_{\mathrm{cj}}=41,4 \mathrm{MPa}$.

Como agregado miúdo utilizou-se areia natural, enquadrada como areia média dentro dos limites granulométricos conforme a NBR 7211. Foram feitos os 
ensaios de caracterização da areia, obtendo-se para a massa específica real o valor de $2,62 \mathrm{~g} / \mathrm{cm}^{3}$ e para a massa unitária o valor de 1,51 .

\subsection{Armadura: tipo e disposição}

Para o lote de aço adquirido foram determinados os limites de escoamento, de ruptura, módulo de elasticidade e diagrama tensão-deformação. Os ensaios de tração foram realizados conforme a NBR 6152, utilizando controle de deslocamento de $0,03 \mathrm{~mm} / \mathrm{s}$, através da máquina universal de ensaios marca DARTEC, com capacidade de 100kN, obtendo-se os resultados da tab.C1.

TABELA C1 - Propriedades das barras de aço

\begin{tabular}{|c|c|c|c|}
\hline $\begin{array}{c}\text { Diâmetro da barra } \\
(\mathrm{mm})\end{array}$ & $\begin{array}{c}\text { Limite de Escoamento } \\
(\mathrm{MPa})\end{array}$ & $\begin{array}{c}\text { Limite de Ruptura } \\
(\mathrm{MPa})\end{array}$ & $\begin{array}{c}\text { Módulo de Elasticidade } \\
(\mathrm{MPa})\end{array}$ \\
\hline 6,3 & 580,64 & 796,64 & $178.705,2$ \\
\hline 8,0 & 554,40 & 644,58 & $173.071,2$ \\
\hline
\end{tabular}

Utilizaram-se telas soldadas como armadura das placas de argamassa, na confecção dos dois modelos. A designação da tela é EQ-98, aço CA-60 com diâmetro do fio de $2,5 \mathrm{~mm}$, com espaçamento de $5,0 \mathrm{~cm}$ entre os fios longitudinais e transversais.

A tela para o modelo VT 01 foi cortada e dobrada de maneira que a placa de EPS (núcleo) ficasse totalmente envolvida pela tela soldada (fig.C2).
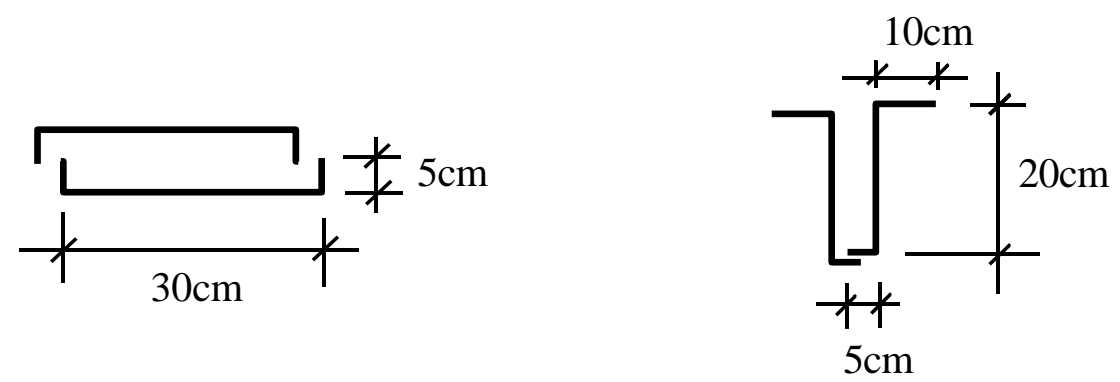

FIGURA C2 - DETALHE DO DOBRAMENTO DA TELA SOLDADA (MODELO VT 01)

Como armadura complementar utilizaram-se 10 barras de aço com diâmetro de 6,3 mm, localizadas na parte inferior e nas laterais da alma fig.C3. 


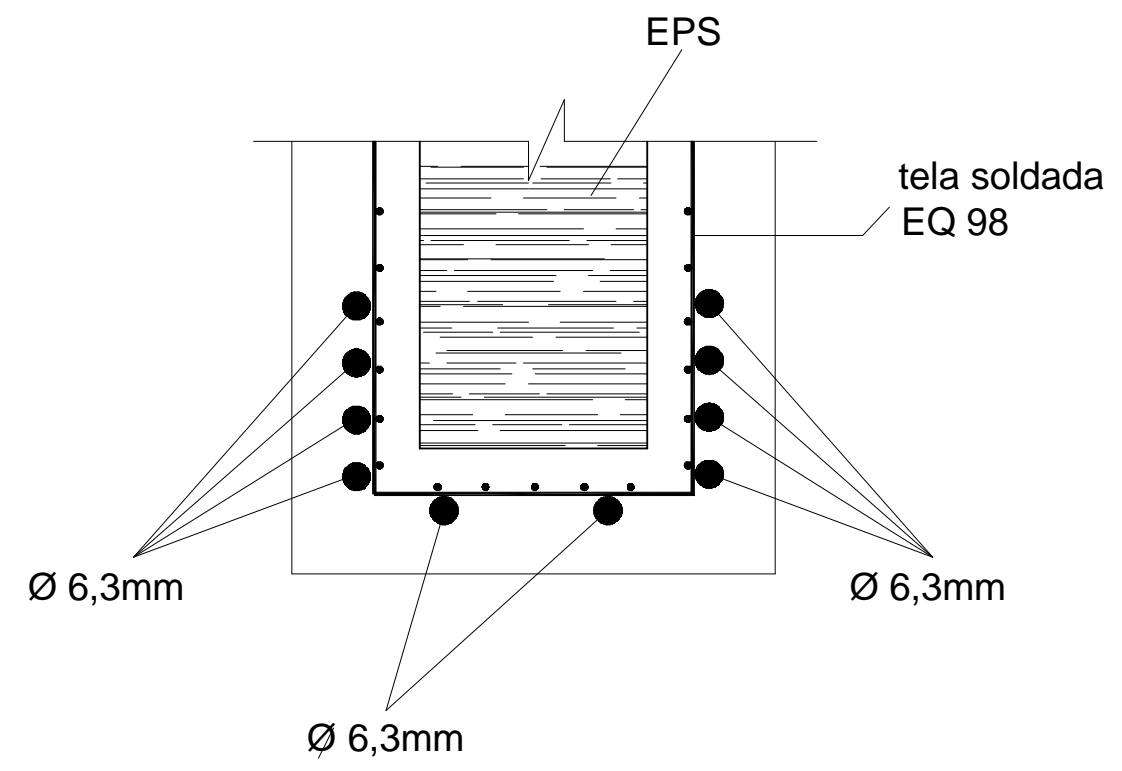

FIGURA C3 - POSICIONAMENTO DA ARMADURA DE TRAÇÃO NA VT 01.

DISTRIBUIÇÃO DAS BARRAS

\subsection{Núcleo}

Como material do núcleo utilizaram-se, para os dois modelos, placas de poliestireno expandido (EPS) de 50mm de espessura, popularmente conhecido como isopor. O painel de EPS para o modelo VT 01 foi cortado nos tamanhos mostrados na fig.C4.

Placa 1 - mesa da viga;

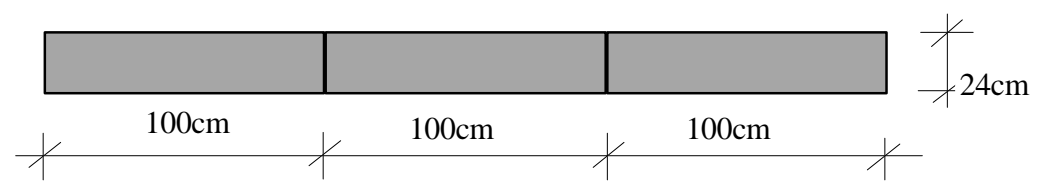

Placa 2 - alma da viga.

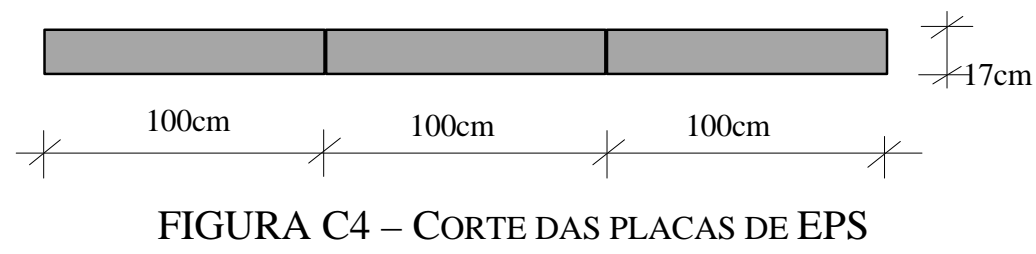




\section{CONFECÇÃO DA VIGA T}

\subsection{Montagem da armadura}

Montaram-se separadamente a mesa e a alma da viga, amarrando-se com arames as telas soldadas, cortadas e dobradas conforme a fig.C5, envolvendo a placa de EPS. Em seguida foi conectada a alma na mesa da viga, através do traspasse deixado na armadura da alma. Depois de conectadas a mesa e a alma, posicionaramse as barras de aço da armadura complementar. As figuras C5 e C6 mostram, respectivamente, a seção da viga já montada e uma vista lateral da viga armada, pronta para o início da argamassagem. Na fig.C5 observa-se o posicionamento da armadura complementar, localizada na parte inferior e nas laterais da alma.

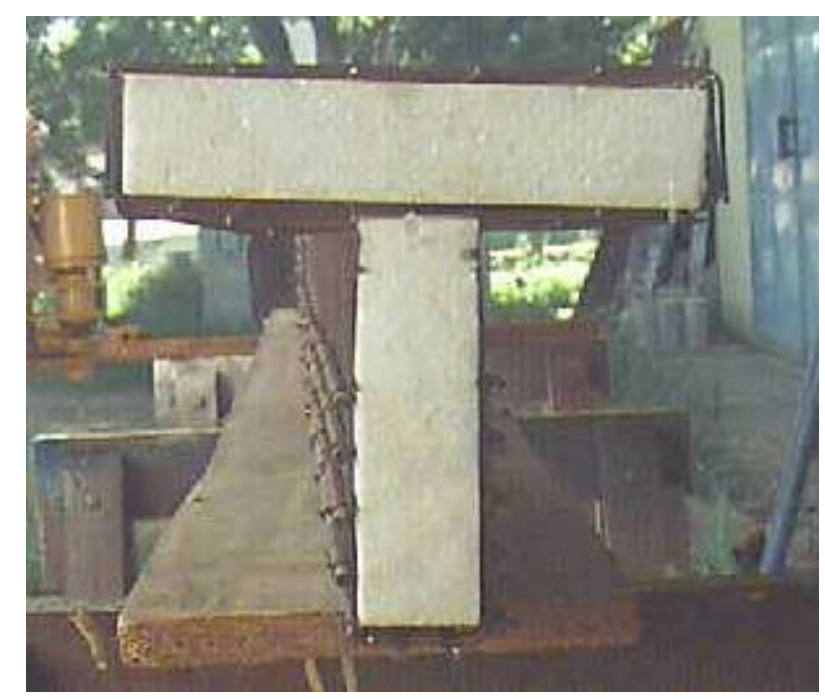

FIGURA C5 - SEÇÃO TRANSVERSAL DA VIGA

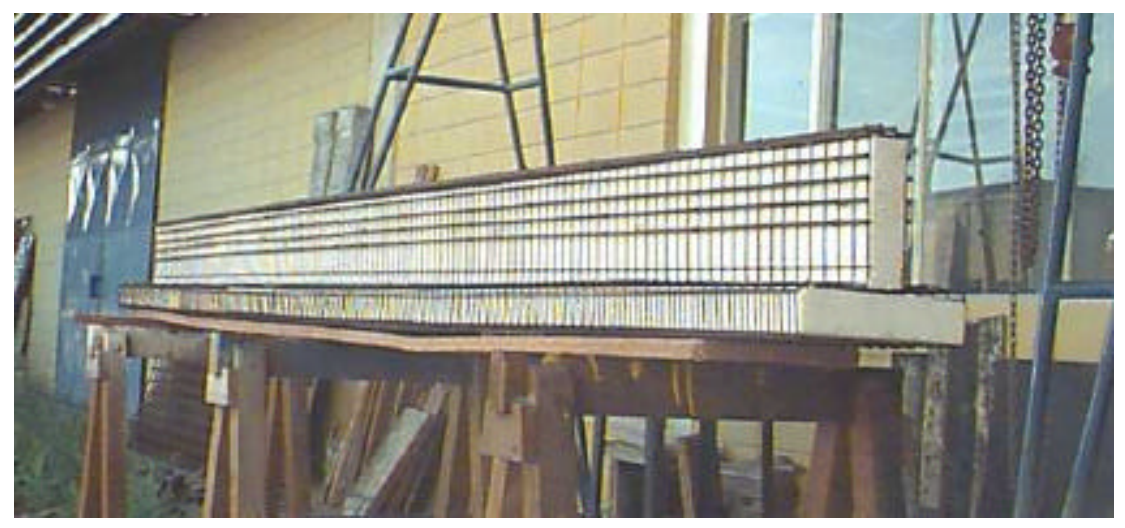

FIGURA C6 - VISTA LATERAL DA VT 01 PRONTA PARA O INÍCIO DA ARGAMASSAGEM. 


\subsection{Argamassagem da viga}

A viga foi montada e colocada em cima de cavaletes, onde recebeu um cobrimento de argamassa de 2,5cm de espessura. Essa argamassagem foi feita em duas etapas e aplicada manualmente através de uma colher de pedreiro. A argamassagem desse modelo foi realizada horizontalmente. Na primeira etapa, a viga $\mathrm{T}$ foi colocada em cima dos cavaletes na posição invertida, e, em seguida, realizada a argamassagem. Somente quando a argamassa da aplicação da primeira etapa atingiu resistência suficiente, a viga foi invertida novamente para argamassagem da parte de cima da mesa. As figuras C7, C8 e C9 mostram o processo de argamassagem do modelo VT 01.

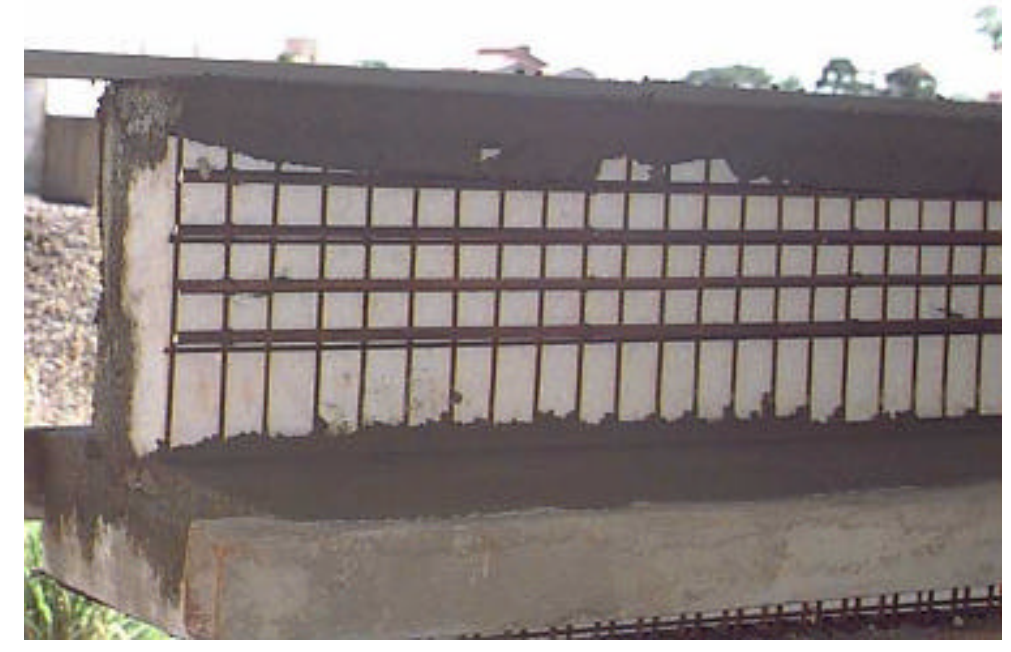

FIGURA C7 - PRIMEIRA ETAPA DA ARGAMASSAGEM. ALMA E PARTE INFERIOR DA

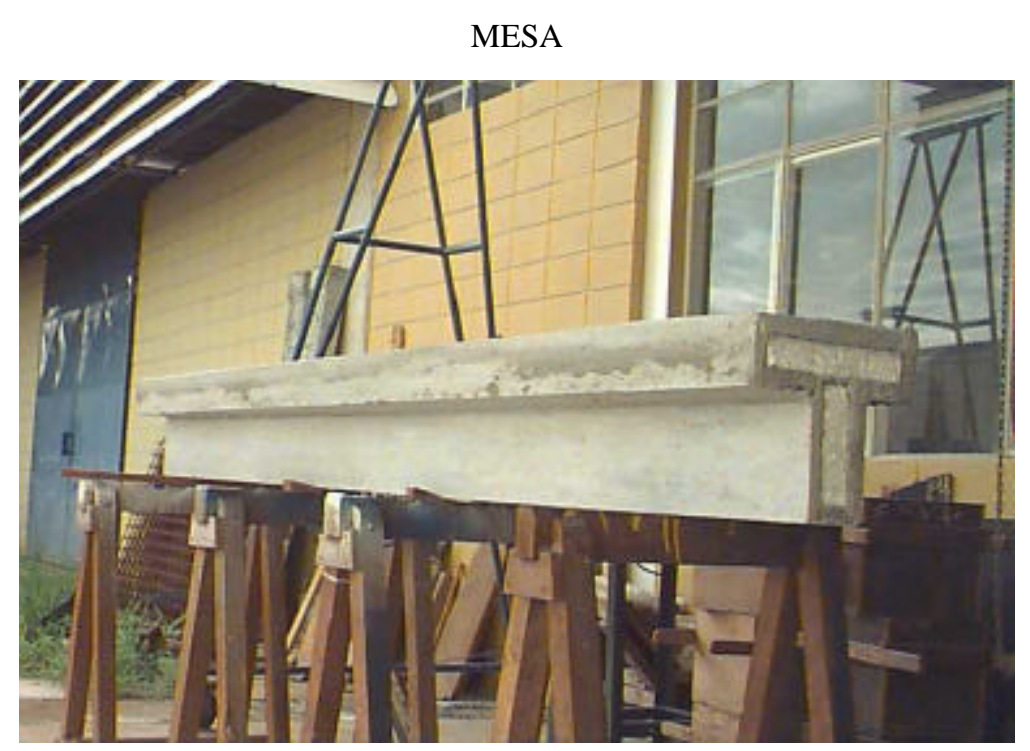

FIGURA C8 - VIGA PRONTA APÓS A SEGUNDA ETAPA DA ARGAMASSAGEM 


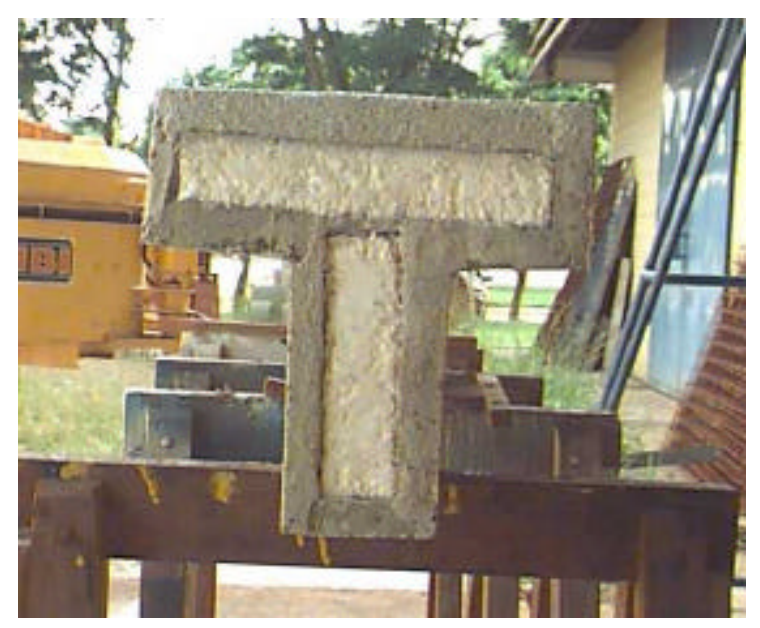

FIGURA C9 - SEÇÃO TRANSVERSAL DO MODELO VT 01

\section{ESQUEMAS ESTÁTICO, DE CARREGAMENTO E INSTRUMENTAÇÃO}

O esquema estático adotado para foi o de uma viga simplesmente apoiada e submetida a um carregamento nos terços do vão.

A força foi aplicada em incrementos de $5 \mathrm{kN}$, através de um cilindro hidráulico acoplado a uma bomba hidráulica de acionamento manual. Foram medidos os deslocamentos em 5 pontos da viga, através de transdutores elétricos de sensibilidade de 0,05mm, com um curso de $100 \mathrm{~mm}$, de marca Kywoa, modelo DT $100 \mathrm{~A}$.

A fig.C10 mostra o esquema estático e de carregamento, bem como o posicionamento dos transdutores.

Utilizou-se para registro das leituras do modelo VT 01, indicado pela célula de carga e pelos transdutores elétricos, um sistema de aquisição de dados, de marca Measurements Group, modelo System 4000.

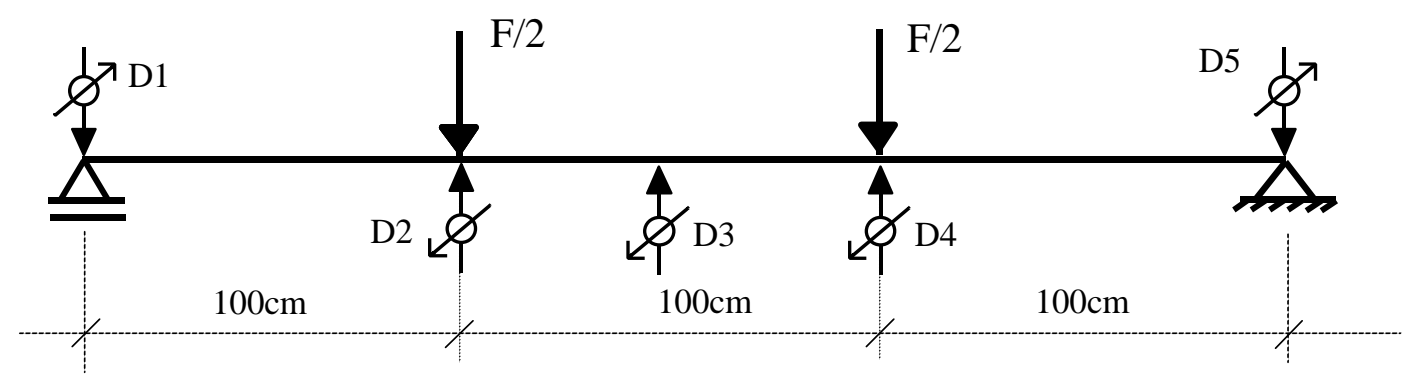

FIGURA C10 - ESQUEMA ESTÁTICO, DE CARREGAMENTO E INSTRUMENTAÇÃO 
A fig.C11 mostra o modelo VT 01 pronto para o inicio do ensaio.

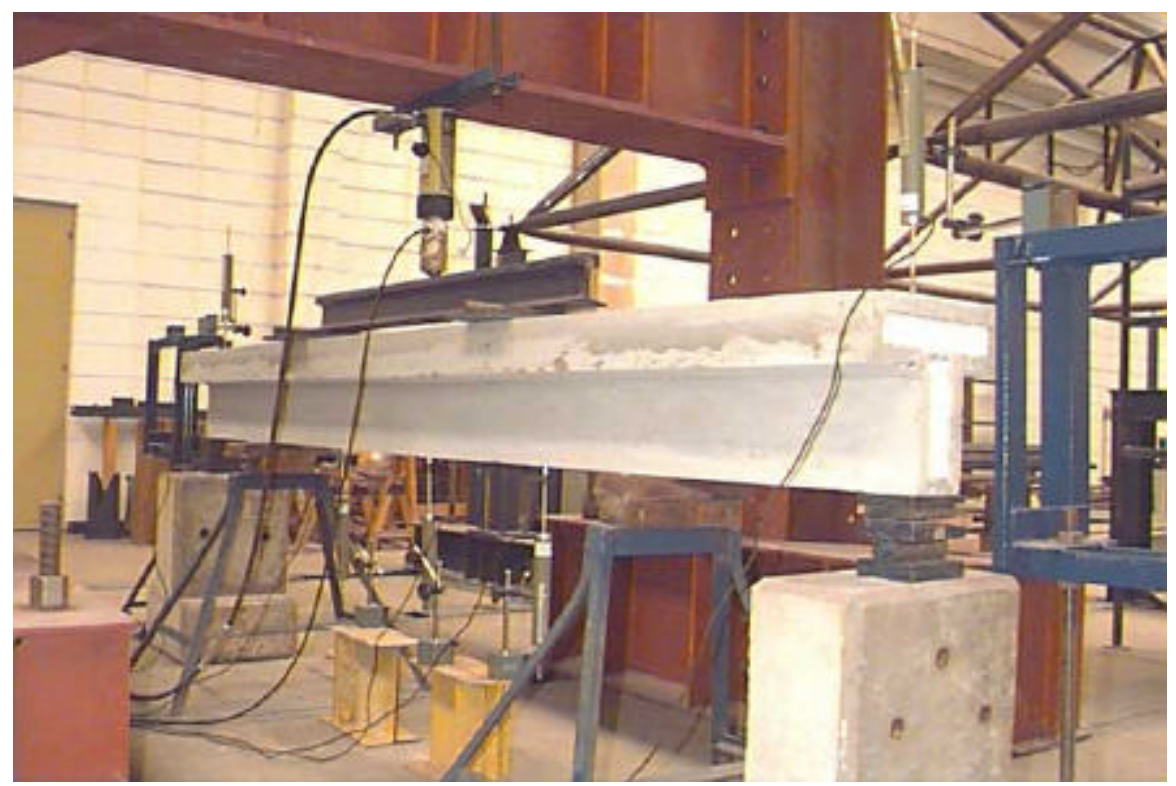

FIGURA C11 - MODELO VT 01 PRONTO PARA O INÍCIO DO ENSAIO. DETALHE DOS APOIOS, MECANISMO DE APLICAÇÃO DE CARGA COM O MACACO HIDRÁULICO, PÓRTICO DE REAÇÃO E DEFLETÔMETROS

\section{RESULTADOS OBTIDOS E ANÁLISE DOS RESULTADOS}

A carga última verificada foi de $60 \mathrm{kN}$, e a ruptura se deu por cisalhamento da argamassa na região localizada próxima ao apoio. Foram medidos os deslocamentos no meio do vão e a evolução das fissuras no decorrer do ensaio. O gráfico da fig.C12 mostra o diagrama força $\mathrm{x}$ deslocamento para os resultados experimentais da viga $\mathrm{T}$ sanduíche e para uma viga $\mathrm{T}$ maciça de seção equivalente, considerando-se os dois estádios de comportamento do concreto à flexão.

\subsection{Momento de fissuração}

O momento de fissuração $\left(\mathrm{M}_{\mathrm{r}}\right)$ é o momento fletor capaz de provocar a primeira fissura na peça. Segundo o anexo da NBR 7197 (1989), seu cálculo é feito no estádio I, considerando diagrama triangular de tensões no concreto.

$\mathrm{O}$ valor teórico do momento de fissuração é $\mathrm{M}_{\mathrm{r}, \mathrm{teo}}=5,4 \mathrm{kNm}$, e o valor experimental do momento de fissuração obtido no ensaio foi de $\mathrm{M}_{\mathrm{r}, \exp }=5,0 \mathrm{kNm}$. 
O modelo utilizado no cálculo do momento de fissuração fornece um resultado $8 \%$ maior que o valor experimental.

\subsection{Momento de ruptura}

No dimensionamento da viga foram levadas em conta a mesmas hipóteses do concreto armado descritas na NBR 6118, considerando-se a seção efetiva da seção tipo sanduíche. A força última teórica determinada foi de $90 \mathrm{kN}$.

A força para a qual ocorreu a ruína da viga no ensaio foi de $60 \mathrm{kN}$. O valor esperado da força resultou em $50 \%$ maior que o valor experimental. O valor baixo da força última experimental reflete uma ligação ruim entre a mesa e a alma da viga VT 01.

A ruptura da viga ocorreu próxima ao apoio, evidenciando uma ruptura por cisalhamento, pois as aberturas das fissuras eram maiores na face inferior. Somente a tela soldada não foi suficiente para combater o esforço cortante atuante na seção.

\subsection{Deslocamentos}

$\mathrm{O}$ cálculo dos deslocamentos para a viga $\mathrm{T}$ equivalente foi feito primeiramente para a seção não fissurada (estádio I), onde o momento atuante é menor que o momento de fissuração. Para o momento atuante maior que o momento de fissuração, o cálculo dos deslocamentos foi feito utilizando-se momento de inércia efetivo, situado entre o momento de inércia do estádio I e o do estádio II, pois a peça apresenta regiões fissuradas intercaladas por regiões não fissuradas, configurando assim uma situação intermediária entre os dois estádios. O momento de inércia foi obtido através da expressão empírica (Fórmula de Branson) fornecida pelo ACI.

Como se pode observar, analisando o gráfico da fig.C12, os deslocamentos determinados teoricamente resultaram em valores menores que os experimentais. A diferença entre eles ficou em torno de $50 \%$. 


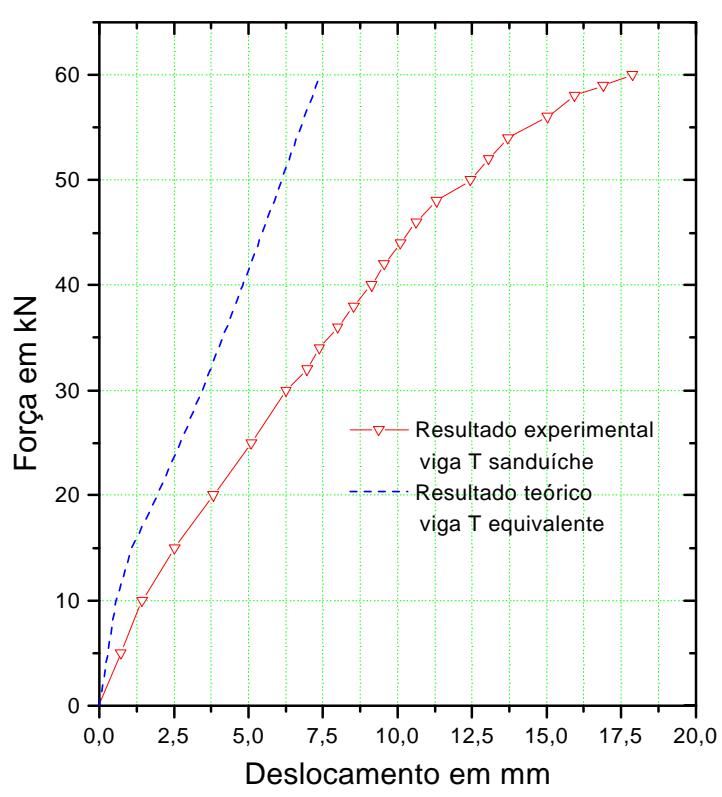

FIGURA C12 - GRÁFICO ForÇA X DESLOCAMENTO (NO MEIO DO VÃO)

Algumas fissuras iniciais, por causa da retração da argamassa durante a execução, influenciaram o comportamento estrutural da peça. Durante a execução do ensaio, apareceram fissuras horizontais ao longo da região da ligação mesa-alma (painel-painel), que se estendiam praticamente de um extremo a outro da viga. A distribuição dessas fissuras não era uniforme. Por o modelo ter sido feito em duas etapas, verificaram-se ainda fissuras nas interfaces das argamassas executadas em diferentes idades, o que influenciou de maneira negativa o comportamento da viga à flexão (figuras C13 e C14).

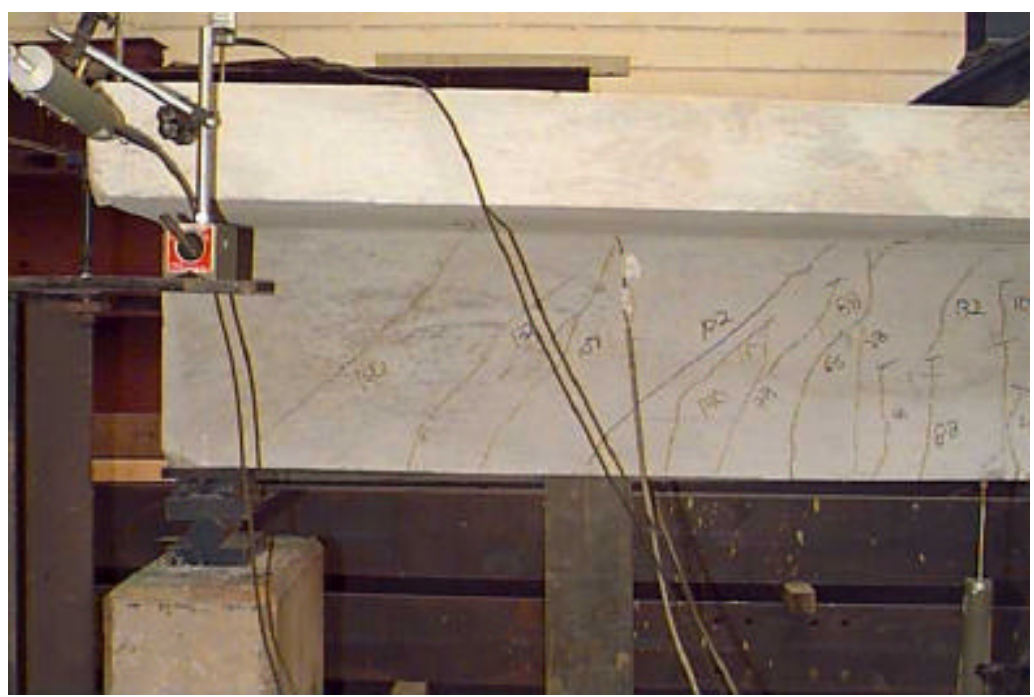

FIGURA C13 - CONFIGURAÇÃO DAS FISSURAS PRÓXIMO AO APOIO 


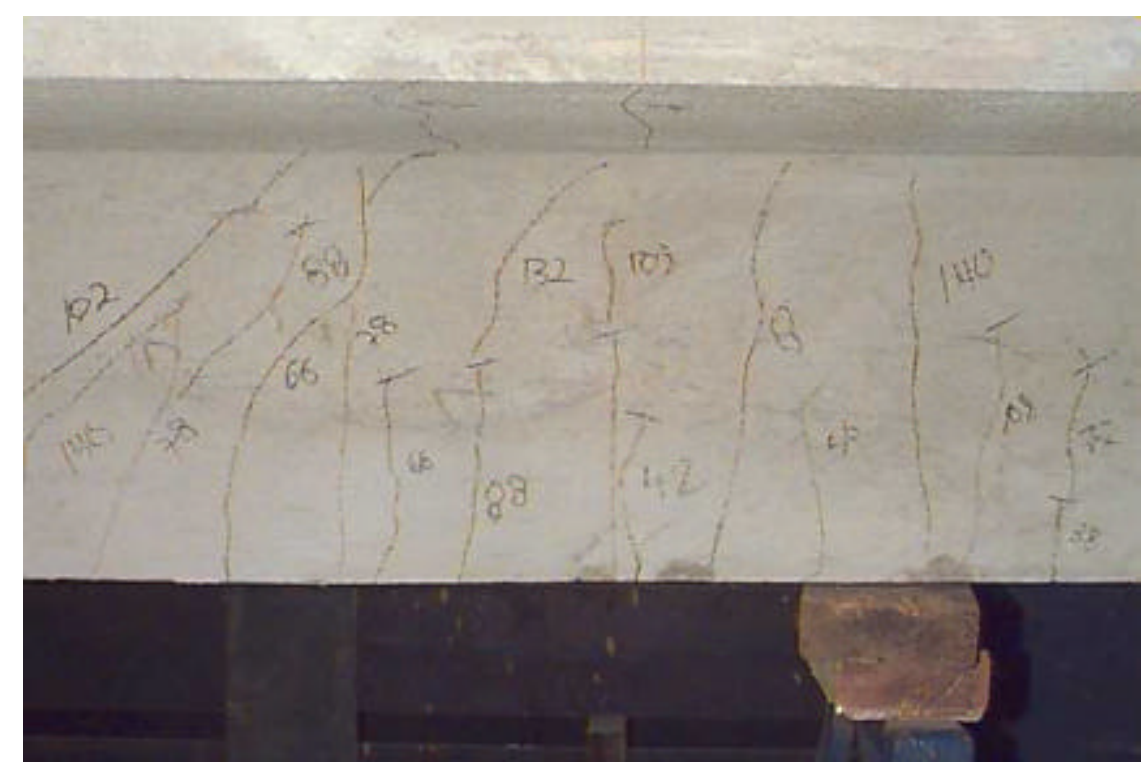

FIGURA C14 - CONFIGURAÇÃO DAS FISSURAS NO MEIO DO VÃO

Da análise dos resultados obtidos nota-se que o tipo de seção adotada para a viga VT 01 não proporciona uma ligação eficiente entre a mesa e a alma.

Esse ensaio funcionou principalmente como teste-piloto, com o intuito de verificar as principais dificuldades de execução e de ensaio do protótipo. Com esse ensaio pôde-se programar melhor a execução e o ensaio do modelo VT 02, eliminando-se os erros cometidos e adotando-se uma seção mais eficiente, ao reforçar a ligação mesa-alma. 


\section{ANEXO D - ENSAIO DE COMPRESSÃO EM PAINÉIS TIPO SANDUÍCHE}

\section{ENSAIO DE COMPRESSÃO EM PAINÉIS TIPO SANDUÍCHE}

Foram confeccionados e ensaiados à compressão painéis tipo sanduíche que tinham as mesmas dimensões dos painéis ensaiados à flexão (modelos PSF). O modo de confecção desses painéis, bem como suas dimensões e materiais utilizados, são detalhados no capítulo 7. Esses painéis foram designados por PSC.

Devido a problemas ocorridos durante os ensaios, a análise dos resultados ficou prejudicada, de sorte que não foi possível tirar conclusões precisas a respeito do ensaio.

O ensaio é descrito a seguir, apontando-se as falhas e fazendo-se algumas considerações a respeito.

\section{ESQUEMA ESTRUTURAL E INSTRUMENTAÇÃO}

Para o ensaio de compressão centrada, modelos da série PSC, foi adotado como esquema estrutural um painel biarticulado, submetido a um carregamento axial, conforme mostra a fig.D1. A força foi aplicada por meio de dois cilindros hidráulicos, com capacidade de 500kN cada um, acoplados a uma bomba hidráulica elétrica. As figuras D2 e D3 mostram o pórtico de reação e o aparato para a aplicação do carregamento.

Foram medidos os deslocamentos verticais em quatro pontos no centro do painel, por meio de transdutores elétricos da marca Kyowa, modelo DT 100 A, com sensibilidade de $0,05 \mathrm{~mm}$ e curso de $100 \mathrm{~mm}$, conforme mostram as figuras D4 e D5. Ainda foram medidos os deslocamentos horizontais em oito pontos: quatro na parte superior a $25 \mathrm{~cm}$ da extremidade, nos dois lados do painel, e quatro no centro, distribuídos nos quartos da largura, dos dois lados do painel. Colocaram-se transdutores para medir os deslocamentos horizontais nos dois lados do painel, prevendo-se a possibilidade de estufamento da peça. As figuras D6 e D7 mostram a posição e os detalhes de colocação dos transdutores elétricos. 


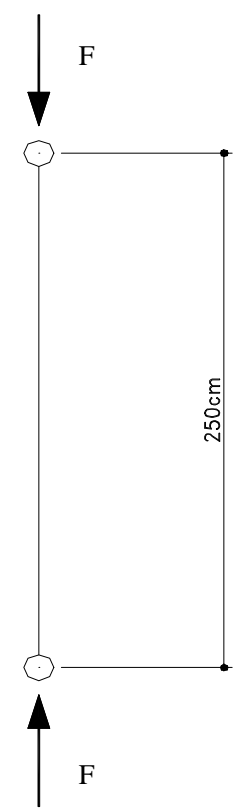

FIGURA D1 - ESQUEMA ESTÁTICO DO ENSAIO DE COMPRESSÃO CENTRADA

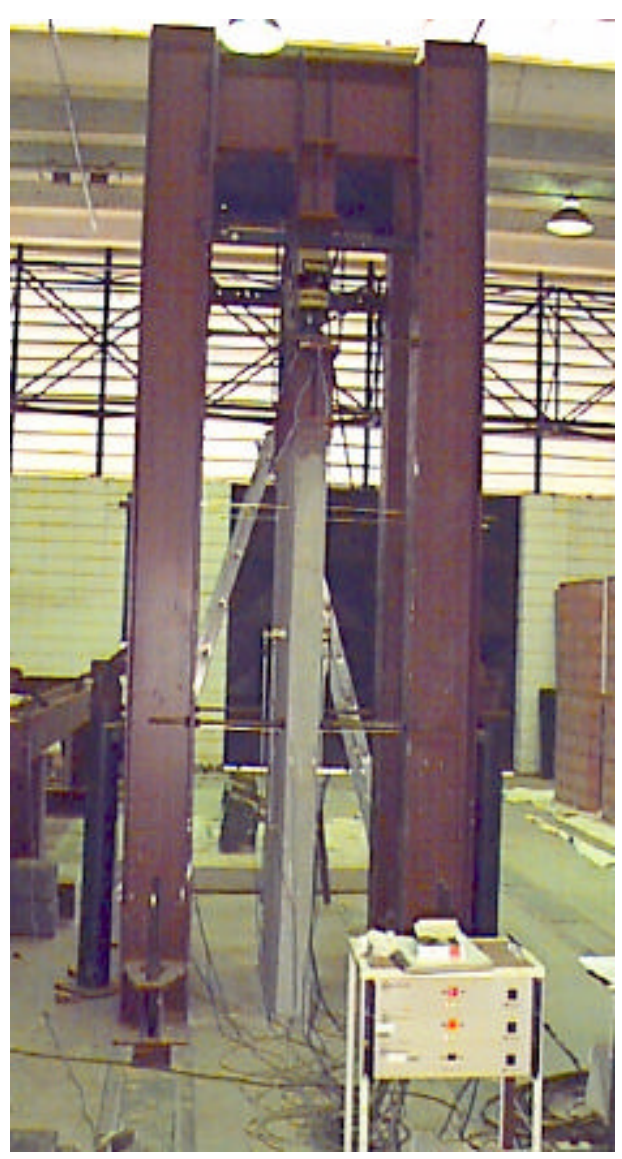

FIGURA D2 - PÓRTICO DE REAÇÃO DO ENSAIO DE COMPRESSÃO CENTRADA 


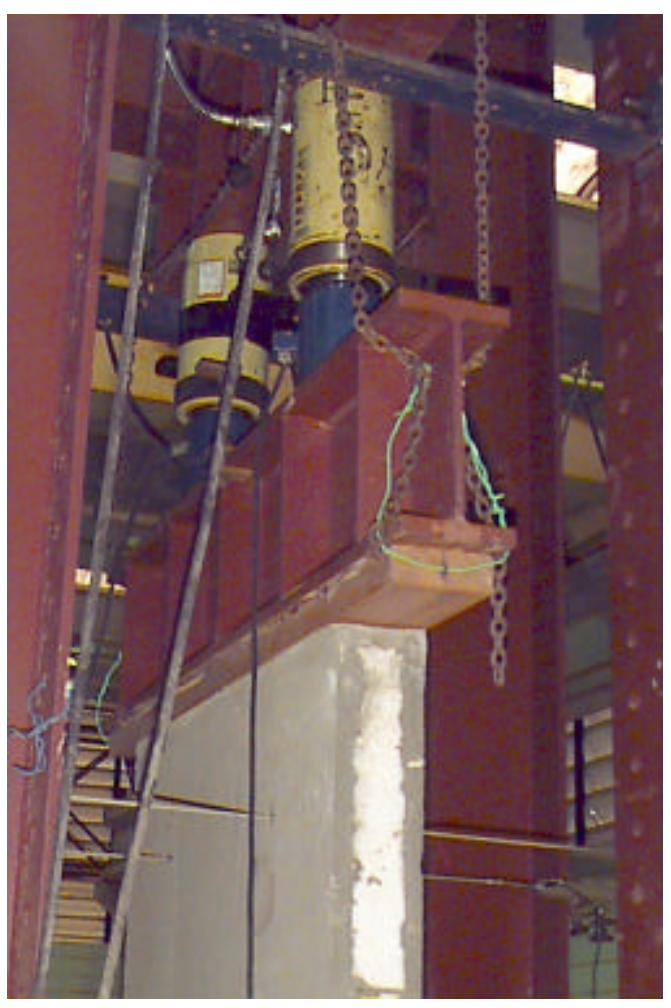

FIGURA D3 - APARATO PARA APLICAÇÃO DO CARREGAMENTO DO ENSAIO DE COMPRESSÃO

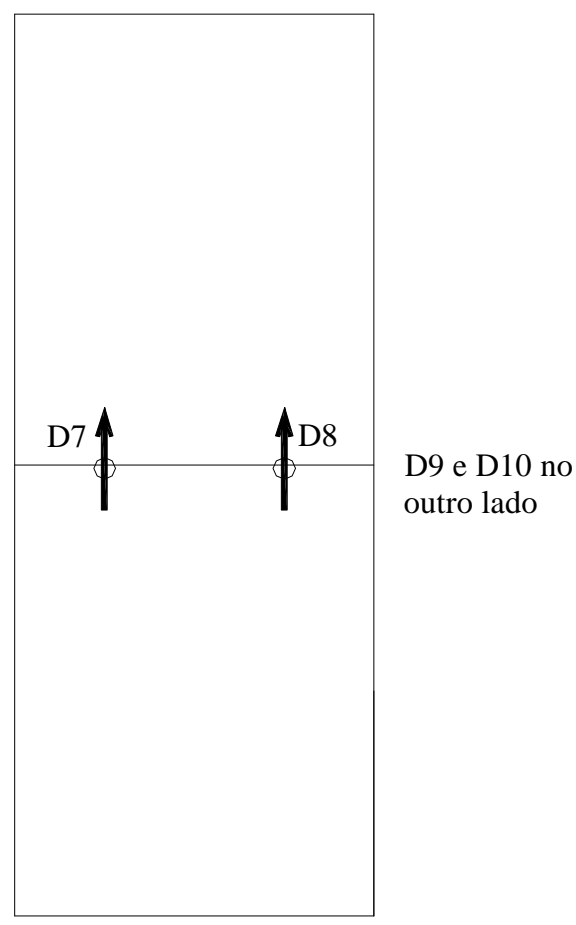

FIGURA D4 - POSIÇÃO DOS TRANSDUTORES ELÉTRICOS POSICIONADOS VERTICALMENTE 


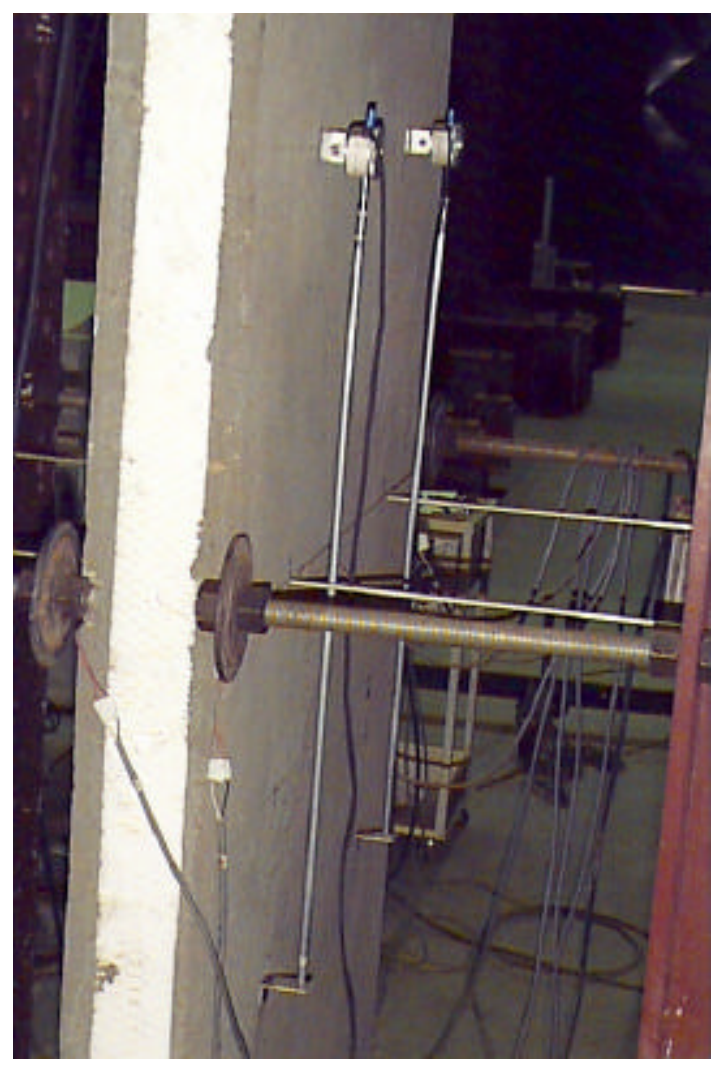

FIGURA D5 - DETALHE DO POSICIONAMENTO DOS TRANSDUTORES ELÉTRICOS VERTICAIS

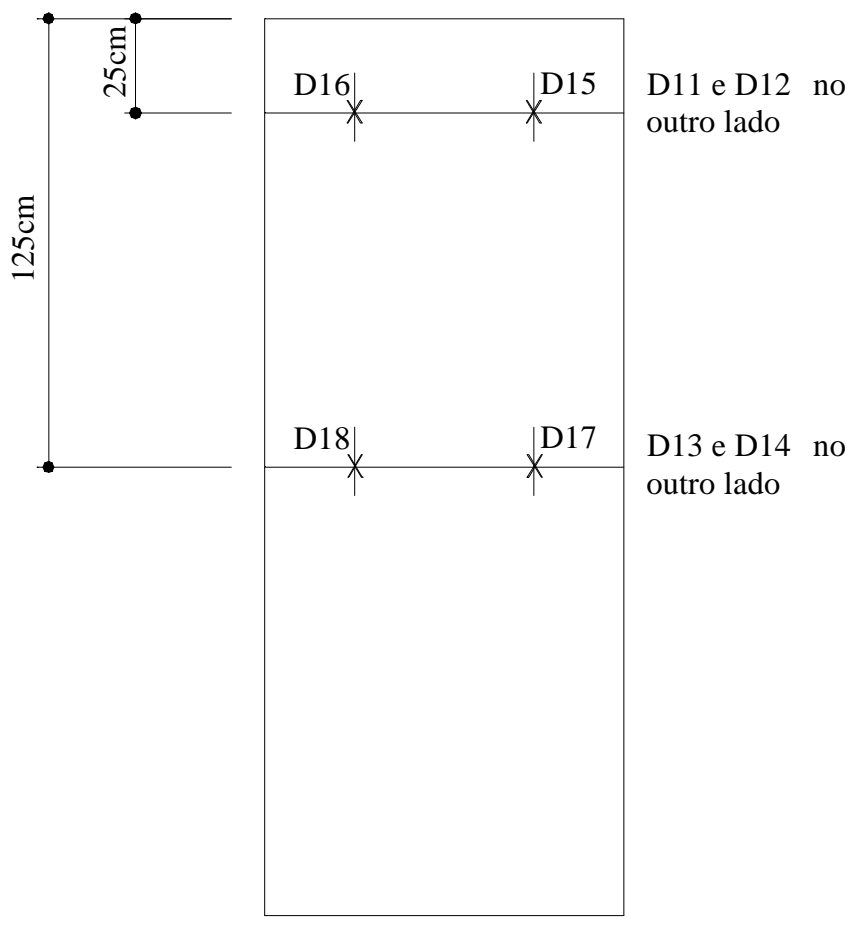

FIGURA D6 - POSIÇÃO DOS TRANSDUTORES ELÉTRICOS COLOCADOS 


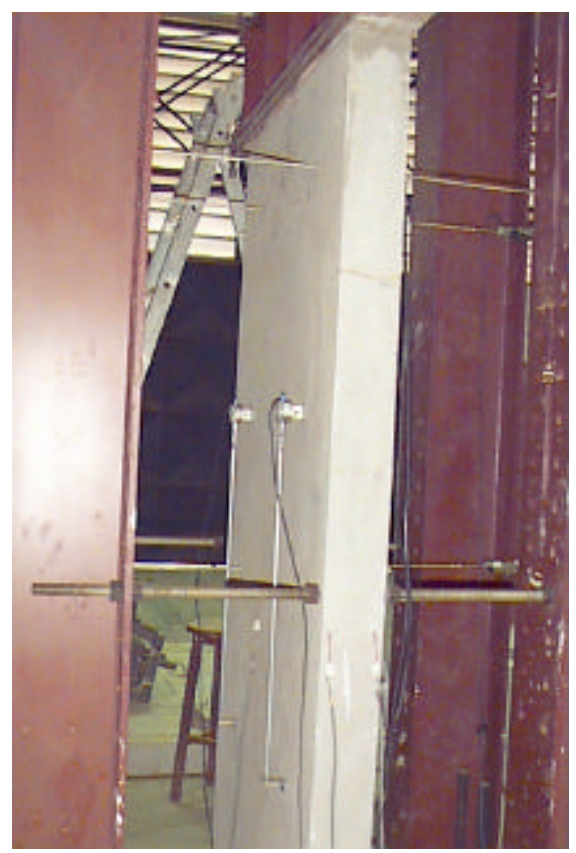

FIGURA D7 - DETALHE DO POSICIONAMENTO DOS TRANSDUTORES ELÉTRICOS HORIZONTAIS

Apenas para controle adicional das deformações do painel, foram colados extensômetros (marca Kyowa e modelo KGF-5-C1-11) em seis pontos, dos quais dois foram posicionados no fio central longitudinal da tela central, e os quatro demais foram colados nos fios da armadura complementar, localizados nas extremidades, conforme mostra a fig.D8.

PSC-I,PSC-II,PSC-IIa, PSC-III,PSC-IIIa

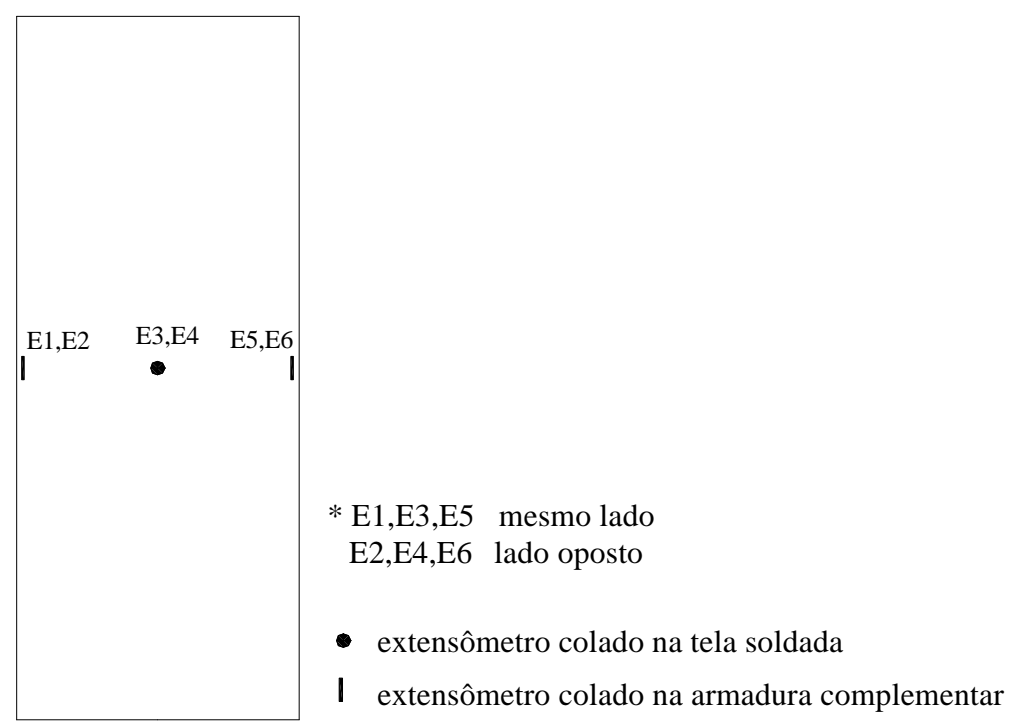


Para registro das leituras indicadas pela célula de carga, pelos transdutores elétricos e pelos extensômetros, utilizou-se um sistema de aquisição de dados de marca Measurements Group, modelo System 5000.

\section{APRESENTAÇÃO DOS RESULTADOS E ANÁLISE}

Os modelos da série PSC foram ensaiados à compressão, considerando-se o painel biarticulado, e foram medidas as deformações na direção da aplicação da carga (direção vertical), bem como a carga última atingida no ensaio. A tab.D1 apresenta os valores das cargas últimas obtidas no ensaio, para cada modelo.

TABELA D1 - Valores das cargas últimas obtidas no ensaio de compressão

\begin{tabular}{|c|c|}
\hline MODELO & Fúltexp $_{\text {exN }}(\mathbf{k N}$ \\
\hline PSC I & 640 \\
\hline PSC II & 501 \\
\hline PSC II $\boldsymbol{a}$ & 746 \\
\hline PSC III & 747 \\
\hline PSC III $\boldsymbol{a}$ & 602 \\
\hline
\end{tabular}

O modo de ruptura para todos os modelos foi por esmagamento da argamassa, na parte superior ou na parte inferior do painel, havendo também o aparecimento de fissuras verticais, localizadas nas nervuras, o que impossibilitou o prosseguimento da aplicação da carga. A fig.D9 mostra o modelo PSC I, sem nervuras, no momento do esmagamento da argamassa, na região próxima da extremidade superior do painel. $\mathrm{O}$ prosseguimento da aplicação da força não era mais possível devido à perda de prumo, tanto do painel quanto do dispositivo de aplicação da carga (fig.D10).

O modelo PSC II (com duas nervuras longitudinais com armadura) rompeu na extremidade inferior do painel, obtendo-se um valor para a carga última de $501 \mathrm{kN}$. $\mathrm{O}$ valor da carga inferior ao do painel PSC I provavelmente ocorreu devido à irregularidade da superfície da base do painel, na qual foi colocada uma chapa metálica como calço na parte inferior, para possibilitar a montagem e a execução do ensaio; isto provocou concentrações de tensões na base, causando um esmagamento na argamassa, impossibilitando a continuação da aplicação da carga. 

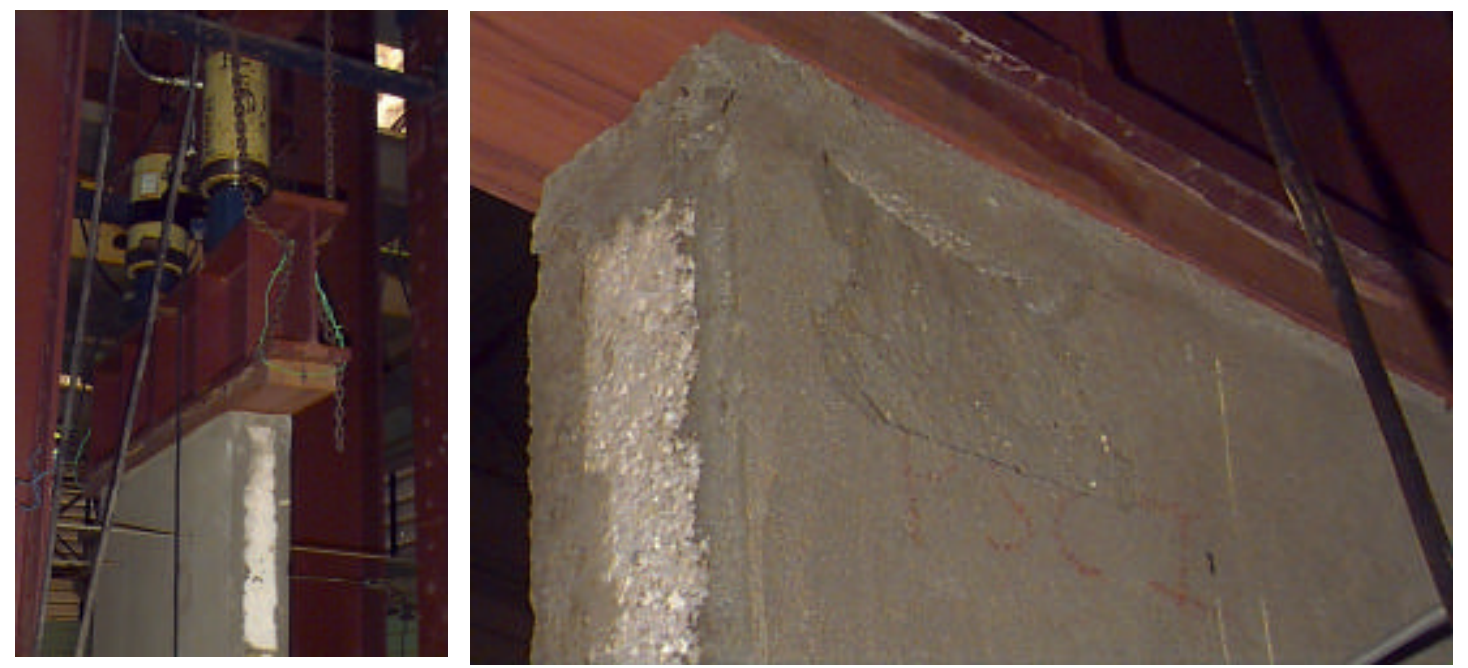

FIGURA D9 - ESMAGAMENTO NA PARTE SUPERIOR DO PSF I

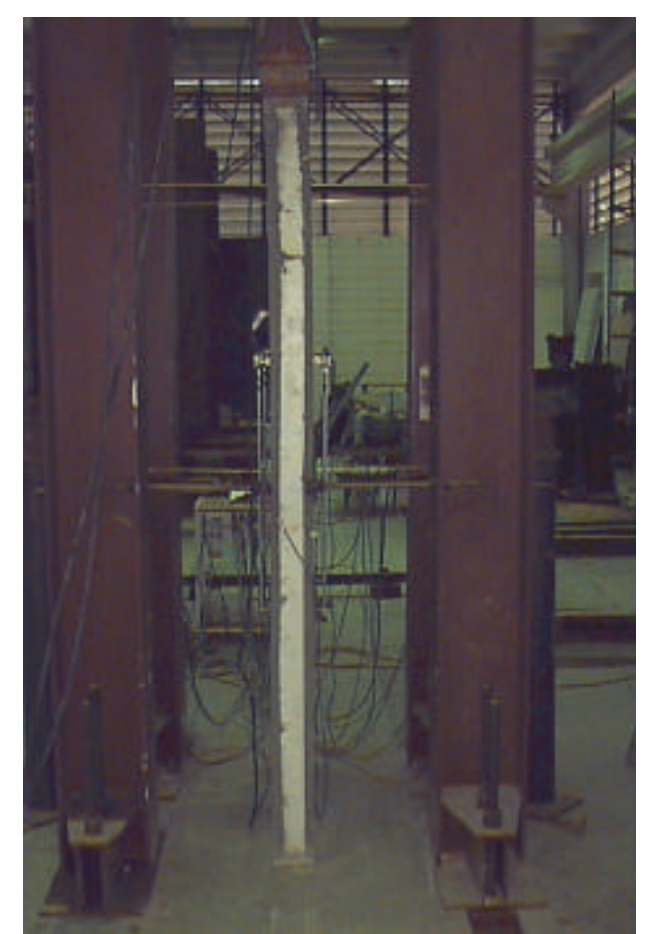

FIGURA D10 - RUPTURA DO MODELO PSC-I

Os modelos PSC-II $a$ (com duas nervuras longitudinais sem armadura) e PSC-III (com três nervuras longitudinais com armadura) tiveram, respectivamente, como carga última, $746 \mathrm{kN}$ e $747 \mathrm{kN}$, rompendo na parte inferior da nervura longitudinal, como mostram as figuras D11 e D12. 


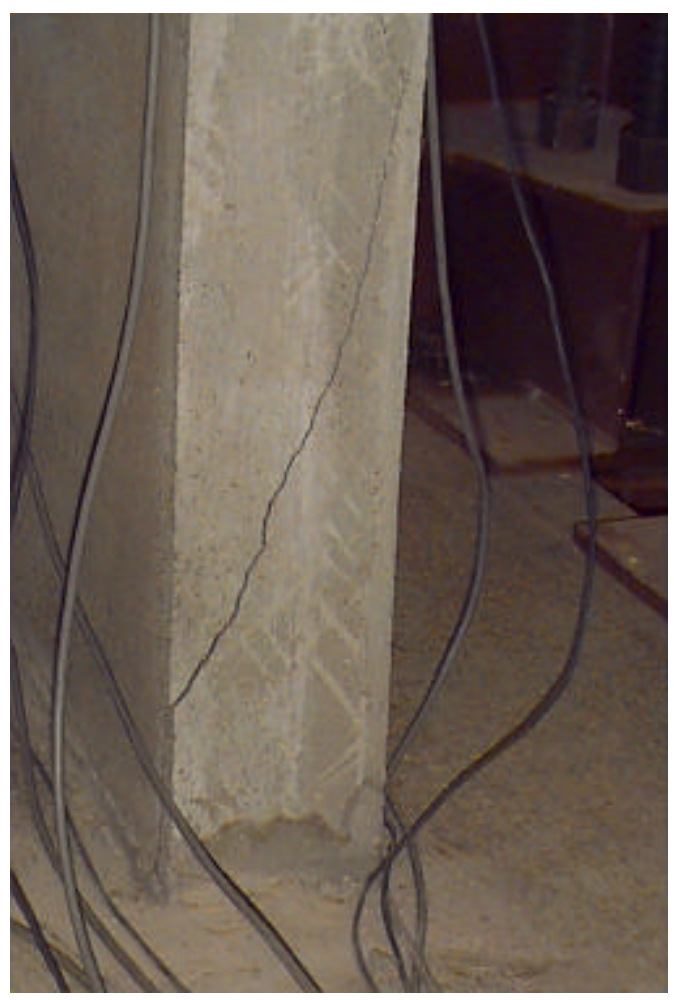

FIGURA D11 - RUPTURA DO PSC-IIA NA NERVURA NA PARTE INFERIOR DO PAINEL

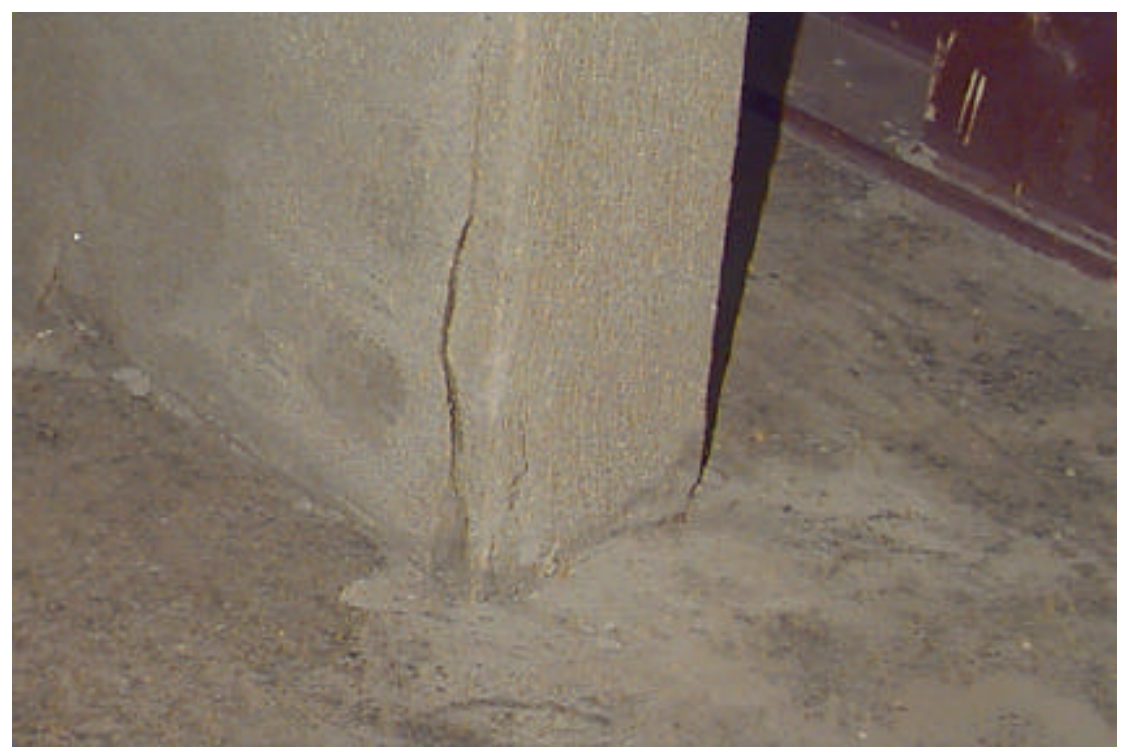

FIGURA D12 - RUPTURA DO PSC-III NA NERVURA NA PARTE INFERIOR DO PAINEL

O ensaio do modelo PSC-III $a$ foi interrompido na etapa de carga de $602 \mathrm{kN}$. Esse modelo rompeu de forma brusca, na parte superior do painel, ocorrendo no momento da ruptura um destacamento de parte da nervura, como mostram as figuras D13 e D14. 


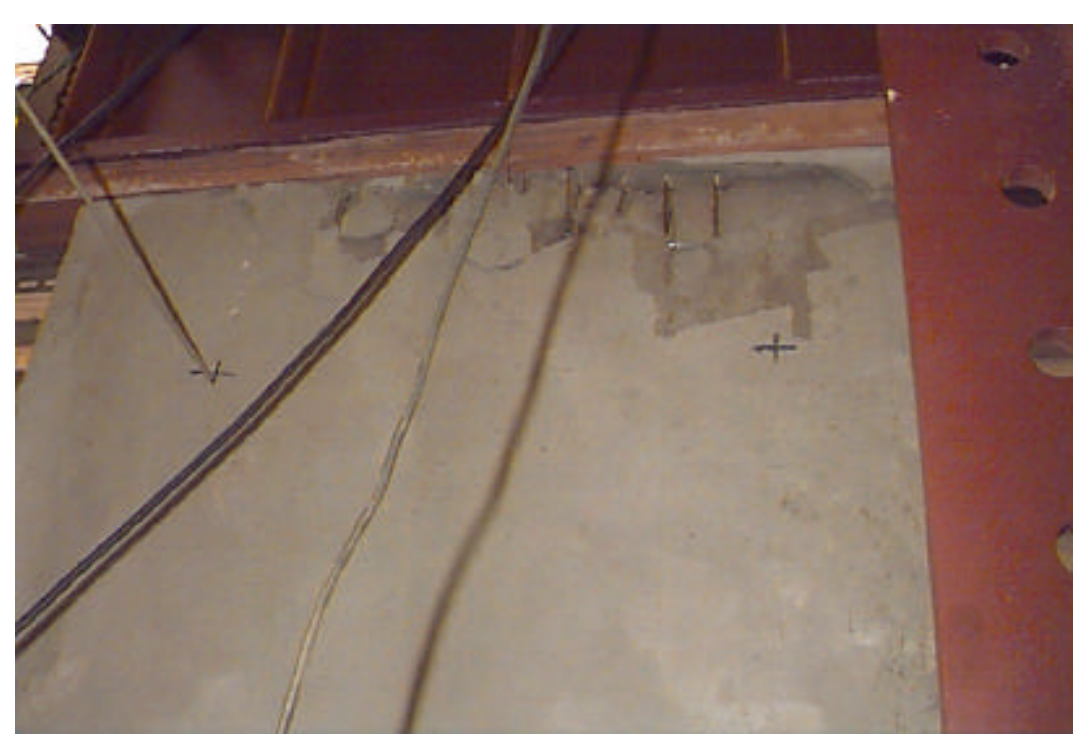

FIGURA D13 - RUPTURA POR ESMAGAMENTO NA PARTE SUPERIOR DO PSC-IIIA

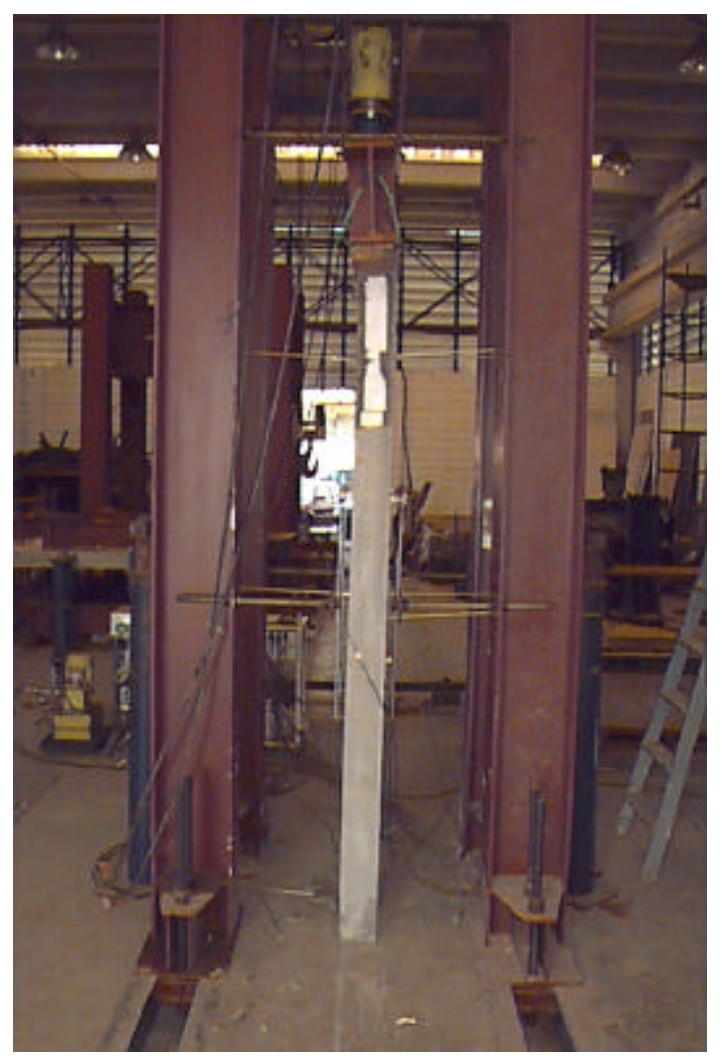

FIGURA D14 - DESTACAMENTO DE PARTE DA NERVURA DO PSC-IIIA

A fig.D15 mostra os gráficos Força x Deformação longitudinal do painel e seus respectivos valores das cargas últimas, para cada modelo. As curvas representam as deformações médias do aço versus a força aplicada, obtidas no ensaio 
para cada face do painel. Pode-se observar através dos gráficos que ocorreu, para todos os modelos, somente compressão nas faces. Pode-se notar ainda que a máxima deformação específica foi de 600 microstrain, que corresponde a $0,6 \%$; isto quer dizer que a capacidade resistente da argamassa e do aço ficou longe de ser atingida, ao mesmo tempo que não houve, nos ensaios, flambagem dos modelos.

A resistência média de compressão obtida dos ensaios de controle da argamassa foi de $65 \mathrm{MPa}$. Pelo modo de execução das faces (por projeção da argamassa), considerou-se uma redução da resistência de $20 \%$, conforme descrito no capítulo 3. Considerando-se a resistência minorada, painel perfeitamente no prumo e carga aplicada perfeitamente no centro linear ao longo da largura, a força, que provocaria ruptura do painel por compressão, desprezando-se as nervuras, seria de aproximadamente $2700 \mathrm{kN}$, calculada a partir da eq.D1.

$$
F_{u}=A_{c} f_{c}+A_{s} f_{y}
$$

onde:

$\mathrm{F}_{\mathrm{u}}=$ força última devida à compressão simples;

$\mathrm{A}_{\mathrm{c}}=$ área total da seção transversal das faces de argamassa;

$\mathrm{A}_{\mathrm{s}}=$ soma das áreas das barras de armadura longitudinal;

$\mathrm{f}_{\mathrm{c}}=$ resistência média do concreto;

$\mathrm{f}_{\mathrm{y}}=$ resistência média de escoamento da armadura longitudinal.

Para a seção completamente composta, o valor da esbeltez do painel é $\lambda=45$. Por causa de um valor relativamente baixo de $\lambda$, era de se esperar uma ruína por compressão da argamassa, com um valor da carga de ruptura próximo de 2700 kN, o que não ocorreu. Supondo-se ter ocorrido flambagem elástica, a tensão crítica na face seria de $\sigma_{\mathrm{cr}}=1,02 \mathrm{kN} / \mathrm{cm}^{2}$, enquanto a máxima tensão de compressão obtida nas faces dos painéis foi de $\sigma_{\mathrm{c}}=2,0 \mathrm{kN} / \mathrm{cm}^{2}$, eliminando a possibilidade da ocorrência desse tipo de ruína. 

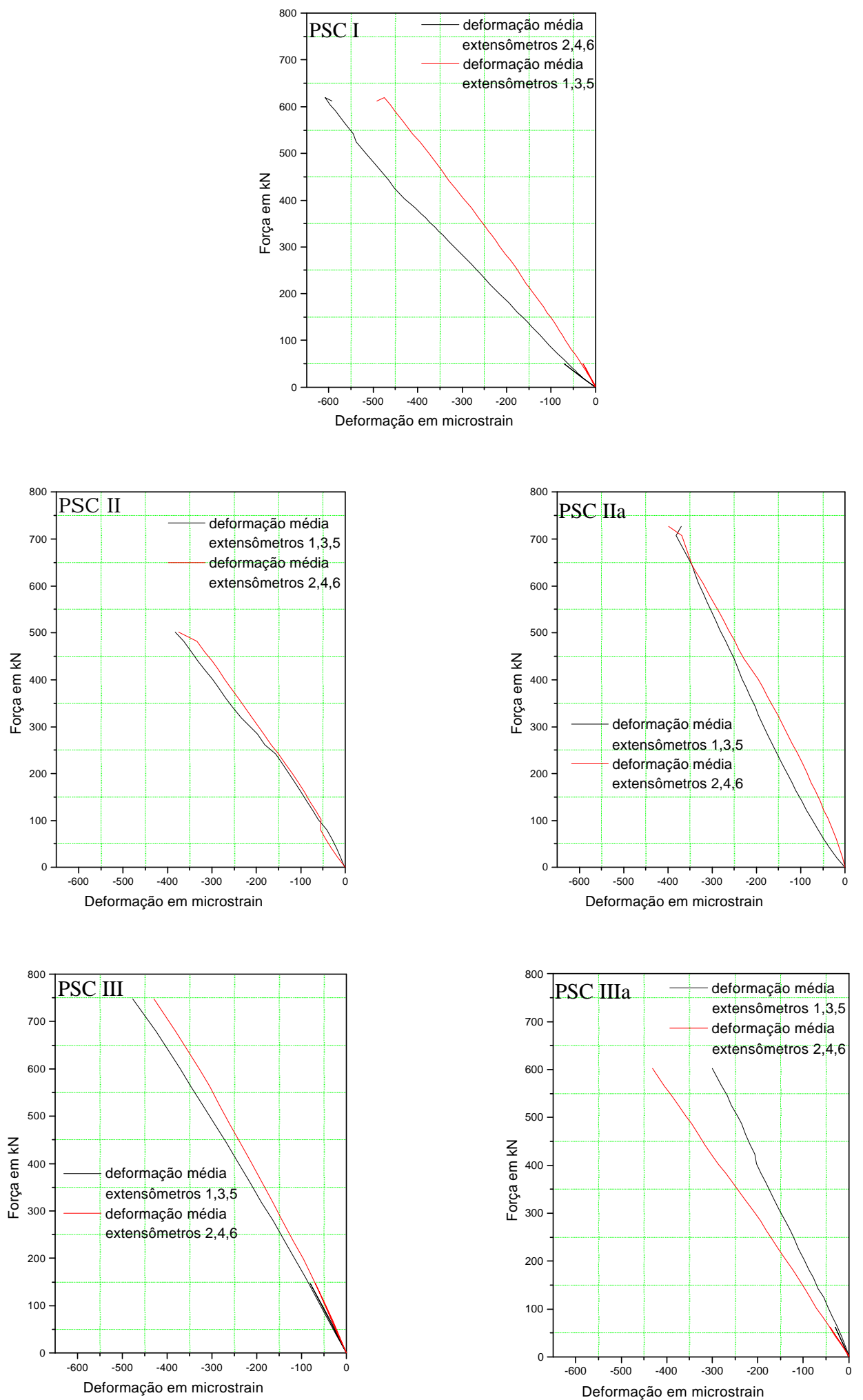

FIGURA D15 - GRÁFICO FORÇA X DEFORMAÇÃO - EXTENSÔMETROS NA ARMADURA 
Outra suposição que pode ser feita é admitir que houve excentricidade da força aplicada, o que configura uma solicitação por flexo-compressão. A partir dos valores obtidos experimentalmente, das deformações, das características mecânicas do aço e do concreto, pode-se determinar os valores dos esforços resistentes e comparar com os respectivos valores experimentais.

Por hipótese considerou-se a seção completamente composta, e que as seções planas permaneciam planas depois de deformadas. Assim, conhecendo-se o valor das deformações nas faces 1 (face menos comprimida) e 2 (face mais comprimida), pode-se determinar a variação ao longo da espessura da seção transversal do painel tipo sanduíche.

Apesar de os valores das deformações nas faces serem conhecidos, optou-se por utilizar os valores das deformações no aço, também conhecidas do ensaio, por fornecerem resultados mais confiáveis que os da argamassa.

Desse modo, as deformações ao longo da espessura do painel tipo sanduíche podem ser determinadas, a partir dos valores das deformações médias do aço, por meio da expressão:

$$
\varepsilon=\varepsilon_{\mathrm{s} 2}+\left(\varepsilon_{\mathrm{s} 1}+\varepsilon_{\mathrm{s} 2}\right)\left(\frac{\mathrm{u}-1,5}{11}\right),
$$

onde:

$\varepsilon=$ deformação em uma posição qualquer, ao longo da espessura da seção sanduíche;

$\varepsilon_{s l}=$ deformação média na armadura mais comprimida;

$\varepsilon_{s 2}=$ deformação média na armadura menos comprimida;

$\mathrm{u}=$ posição ao longo da espessura da seção sanduíche.

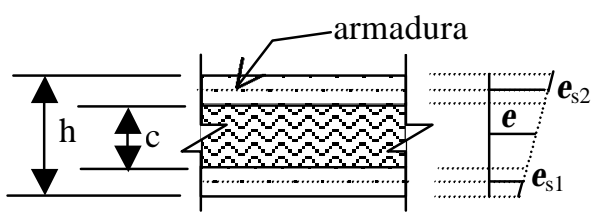

FIGURA D16 - HIPÓTESES DE DISTRIBUIÇÃO DAS DEFORMAÇÕES 
Conhecendo-se a variação das deformações ao longo da espessura da seção transversal do painel tipo sanduíche e adotando-se uma relação tensão x deformação parabólica para o concreto, determinam-se as tensões nas faces das placas de argamassa. Por integração obtêm-se o esforço normal resistente teórico e o respectivo momento fletor, usando-se as equações de equilíbrio:

$$
\begin{aligned}
& \mathrm{N}_{\text {teo }}=\int \sigma_{\mathrm{c}} \mathrm{dA}+\sum_{\mathrm{i}} \mathrm{A}_{\mathrm{si}} \sigma_{\mathrm{si}}, \\
& \mathrm{M}_{\text {teo }}=\int \sigma_{\mathrm{c}} \mathrm{udA}+\sum \mathrm{A}_{\mathrm{si}} \sigma_{\mathrm{si}} \mathrm{u}_{\mathrm{i}} .
\end{aligned}
$$

Por simplificação, linearizando-se as tensões da argamassa ao longo das espessuras das faces e aplicando-se as equações de equilíbrio (D3) e (D4), tem-se:

$$
\begin{aligned}
& \mathrm{N}_{\text {teo }}=\left(\frac{\sigma_{\mathrm{c} 2}+\sigma_{\mathrm{c} 2}^{\prime}}{2}\right) \cdot \mathrm{t} \cdot \mathrm{b}+\left(\frac{\sigma_{\mathrm{c} 1}+\sigma_{\mathrm{c} 1}^{\prime}}{2}\right) \cdot \mathrm{t} \cdot \mathrm{b}+\mathrm{A}_{\mathrm{s}}\left(\sigma_{\mathrm{s} 1}+\sigma_{\mathrm{s} 2}\right), \\
& \mathrm{M}_{\text {teo }}=\left[\left(\frac{\sigma_{\mathrm{c} 1}+\sigma_{\mathrm{c} 1}^{\prime}}{2}\right) \cdot \mathrm{t} \cdot \mathrm{b}+\mathrm{A}_{\mathrm{s}} \sigma_{\mathrm{s} 1}\right](\mathrm{h}-\mathrm{t}),
\end{aligned}
$$

onde:

$\sigma_{\mathrm{c} 1}=$ tensão no concreto na face externa da placa menos comprimida;

$\sigma^{\prime}{ }^{\prime} 1=$ tensão no concreto na face interna da placa menos comprimida;

$\sigma_{\mathrm{c} 2}=$ tensão no concreto na face externa da placa mais comprimida;

$\sigma_{c 2}^{\prime}=$ tensão no concreto na face interna da placa mais comprimida;

$\mathrm{t}=$ espessura das placas;

$\mathrm{b}=$ largura do painel.

Substituindo-se os valores nas expressões D5 e D6, determinam-se os valores teóricos resultantes da força normal e do momento fletor.

A tab.D2 mostra os valores das deformações e das forças normais teóricas resultantes, para algumas etapas de carregamento, dos ensaios de compressão dos modelos da série PSC. 
TABELA D2 - Valores das deformações e das forças resistentes $(\mathrm{kN})$

\begin{tabular}{|c|c|c|c|c|c|c|c|c|c|}
\hline Modelo & Etapa & $\varepsilon_{\mathrm{c} 1}$ & $\varepsilon_{\mathrm{c} 1}^{\prime}$ & $\varepsilon_{\mathrm{c} 2}$ & $\varepsilon_{\mathrm{c} 2}^{\prime}$ & $\varepsilon_{\mathrm{s} 1}$ & $\varepsilon_{\mathrm{s} 2}$ & $\mathbf{N}_{\text {teo }}$ & $\mathbf{N}_{\text {exp }}$ \\
\hline \multirow{10}{*}{ PSC I } & 1 & $-0,000001$ & $-0,000002$ & $-0,000002$ & $-0,000002$ & $-0,000002$ & $-0,000002$ & 5,08 & 1,25 \\
\hline & 2 & $-0,000022$ & $-0,000029$ & $-0,000055$ & $-0,000048$ & $-0,000025$ & $-0,000052$ & 98,38 & 40,00 \\
\hline & 3 & $-0,000055$ & $-0,000066$ & $-0,000110$ & $-0,000098$ & $-0,000060$ & $-0,000104$ & 207.90 & 89,38 \\
\hline & 4 & $-0,000079$ & $-0,000095$ & $-0,000151$ & $-0,000135$ & $-0,000087$ & $-0,000143$ & 288,59 & 129,00 \\
\hline & 5 & $-0,000115$ & $-0,000134$ & $-0,000204$ & $-0,000185$ & $-0,000124$ & $-0,000195$ & 395,64 & 180,63 \\
\hline & 6 & $-0,000160$ & $-0,000184$ & $-0,000273$ & $-0,000249$ & $-0,000172$ & $-0,000261$ & 528,28 & 244,00 \\
\hline & 7 & $-0,000246$ & $-0,000279$ & $-0,000398$ & $-0,000366$ & $-0,000263$ & $-0,000382$ & 765.37 & 362.00 \\
\hline & 8 & $-0,000329$ & $-0,000366$ & $-0,000504$ & $-0,000467$ & $-0,000348$ & $-0,000486$ & 964,15 & 465,50 \\
\hline & 9 & $-0,000443$ & $-0,000480$ & $-0,000614$ & $-0,000578$ & $-0,000462$ & $-0,000596$ & 1187,45 & 603,75 \\
\hline & 10 & $-0,000478$ & $-0,000506$ & $-0,000606$ & $-0,000579$ & $-0,000492$ & $-0,000593$ & 1214,74 & 612,00 \\
\hline Modelo & Etapa & $\varepsilon_{\mathrm{c} 1}$ & $\varepsilon_{\mathrm{c} 1}^{\prime}$ & $\varepsilon_{\mathrm{c} 2}$ & $\varepsilon_{c 2}^{\prime}$ & $\varepsilon_{\mathrm{s} 1}$ & $\varepsilon_{\mathrm{s} 2}$ & $\mathbf{N}_{\text {teo }}$ & $\mathbf{N}_{\text {exp }}$ \\
\hline \multirow{10}{*}{ PSC II } & 1 & 0,000000 & 0,000000 & $-0,000001$ & $-0,0000006$ & 0,000000 & $-0,000001$ & 1.22 & 0.00 \\
\hline & 2 & $-0,000046$ & $-0,000042$ & $-0,000028$ & $-0,0000321$ & $-0,000044$ & $-0,000030$ & 80,98 & 60,88 \\
\hline & 3 & $-0,000054$ & $-0,000055$ & $-0,000062$ & $-0,0000600$ & $-0,000054$ & $-0,000061$ & 125,45 & 101,75 \\
\hline & 4 & $-0,000079$ & $-0,000081$ & $-0,000087$ & $-0,0000852$ & $-0,000080$ & $-0,000086$ & 179,35 & 141,25 \\
\hline & 5 & $-0,000118$ & $-0,000120$ & $-0,000128$ & $-0,0001260$ & $-0,000119$ & $-0,000127$ & 263.55 & 200.74 \\
\hline & 6 & $-0,000165$ & $-0,000169$ & $-0,000183$ & $-0,0001794$ & $-0,000167$ & $-0,000181$ & 368,17 & 260,99 \\
\hline & 7 & $-0,000194$ & $-0,000199$ & $-0,000218$ & $-0,0002128$ & $-0,000196$ & $-0,000215$ & 431,53 & 302,24 \\
\hline & 8 & $-0,000238$ & $-0,000245$ & $-0,000272$ & $-0,0002647$ & $-0,000241$ & $-0,000268$ & 527,41 & 360,37 \\
\hline & 9 & $-0,000267$ & $-0,000275$ & $-0,000302$ & $-0,0002947$ & $-0,000271$ & $-0,000298$ & 584.91 & 400,37 \\
\hline & 10 & $-0,000373$ & $-0,000375$ & $-0,000384$ & $-0,000381$ & $-0,000374$ & $-0,000382$ & 758,31 & 501,00 \\
\hline Modelo & Etapa & $\varepsilon_{\mathrm{c} 1}$ & $\varepsilon_{\text {c1 }}^{\prime}$ & $\varepsilon_{\mathrm{c} 2}$ & $\varepsilon_{\mathrm{c} 2}^{\prime}$ & $\varepsilon_{\mathrm{s} 1}$ & $\varepsilon_{\mathrm{s} 2}$ & $\mathbf{N}_{\text {teo }}$ & $\mathbf{N}_{\exp }$ \\
\hline \multirow{10}{*}{ PSC IIa } & 1 & 0,000000 & 0,000000 & 0,000000 & 0,000000 & 0,000000 & 0,000000 & 0.52 & 0.13 \\
\hline & 2 & $-0,000034$ & $-0,000044$ & $-0,000081$ & $-0,000071$ & $-0,000076$ & $-0,000039$ & 125,46 & 105,25 \\
\hline & 3 & $-0,000080$ & $-0,000092$ & $-0,000138$ & $-0,000125$ & $-0,000132$ & $-0,000086$ & 233,30 & 201,74 \\
\hline & 4 & $-0,000146$ & $-0,000158$ & $-0,000202$ & $-0,000190$ & $-0,000196$ & $-0,000152$ & 367,66 & 325,49 \\
\hline & 5 & $-0,000191$ & $-0,000201$ & $-0,000237$ & $-0,000227$ & $-0,000232$ & $-0,000196$ & 446.99 & 401.62 \\
\hline & 6 & $-0,000261$ & $-0,000266$ & $-0,000285$ & $-0,000280$ & $-0,000283$ & $-0,000264$ & 562,79 & 506,87 \\
\hline & 7 & $-0,000319$ & $-0,000322$ & $-0,000332$ & $-0,000329$ & $-0,000331$ & $-0,000321$ & 661,75 & 605,12 \\
\hline & 8 & $-0,000345$ & $-0,000345$ & $-0,000345$ & $-0,000345$ & $-0,000345$ & $-0,000345$ & 697,36 & 643,24 \\
\hline & 9 & $-0,000366$ & $-0,000370$ & $-0,000383$ & $-0,000379$ & $-0,000381$ & $-0,000368$ & 751,10 & 706.87 \\
\hline & 10 & $-0,000449$ & $-0,000419$ & $-0,000310$ & $-0,000340$ & $-0,000325$ & $-0,000434$ & 758,69 & 745,99 \\
\hline Modelo & Etapa & $\varepsilon_{\mathrm{c} 1}$ & $\varepsilon_{\mathrm{c} 1}^{\prime}$ & $\varepsilon_{\mathrm{c} 2}$ & $\varepsilon_{c 2}^{\prime}$ & $\varepsilon_{\mathrm{s} 1}$ & $\varepsilon_{\mathrm{s} 2}$ & $\mathbf{N}_{\text {teo }}$ & $\mathbf{N}_{\exp }$ \\
\hline \multirow{10}{*}{ PSC III } & 1 & 0,000000 & 0,000000 & 0,000000 & 0,000000 & 0,000000 & 0,000000 & 1,04 & 0,25 \\
\hline & 2 & $-0,000056$ & $-0,000060$ & $-0,000072$ & $-0,000069$ & $-0,000071$ & $-0,000058$ & 139,89 & 122,75 \\
\hline & 3 & $-0,000094$ & $-0,000099$ & $-0,000118$ & $-0,000113$ & $-0,000116$ & $-0,000097$ & 228,45 & 199,13 \\
\hline & 4 & $-0,000161$ & $-0,000168$ & $-0,000193$ & $-0,000186$ & $-0,000189$ & $-0,000165$ & 373,64 & 318,74 \\
\hline & 5 & $-0,000210$ & $-0,000217$ & $-0,000246$ & $-0,000238$ & $-0,000242$ & $-0,000213$ & 474,63 & 402,37 \\
\hline & 6 & $-0,000254$ & $-0,000263$ & $-0,000297$ & $-0,000288$ & $-0,000292$ & $-0,000259$ & 567,42 & 480,62 \\
\hline & 7 & $-0,000278$ & $-0,000288$ & $-0,000326$ & $-0,000316$ & $-0,000321$ & $-0,000283$ & 617,10 & 522,75 \\
\hline & 8 & $-0,000322$ & $-0,000334$ & $-0,000377$ & $-0,000365$ & $-0,000371$ & $-0,000328$ & 705.61 & 599,62 \\
\hline & 9 & $-0,000375$ & $-0,000387$ & $-0,000430$ & $-0,000418$ & $-0,000424$ & $-0,000381$ & 801,39 & 678,99 \\
\hline & 10 & $-0,000423$ & $-0,000436$ & $-0,000483$ & $-0,000470$ & $-0,000476$ & $-0,000429$ & 888,95 & 747,24 \\
\hline Modelo & Etapa & $\varepsilon_{\mathrm{c} 1}$ & $\varepsilon_{\mathrm{c1}}^{\prime}$ & $\varepsilon_{\mathrm{c} 2}$ & $\varepsilon_{\mathrm{c} 2}^{\prime}$ & $\varepsilon_{\mathrm{s} 1}$ & $\varepsilon_{\mathrm{s} 2}$ & $\mathbf{N}_{\text {teo }}$ & $\mathbf{N}_{\exp }$ \\
\hline \multirow{10}{*}{ PSC IIIa } & 1 & 0,000000 & 0,000000 & 0,000000 & 0,000000 & 0,000000 & 0,000000 & 0,35 & 0,00 \\
\hline & 2 & $-0,000014$ & $-0,000018$ & $-0,000031$ & $-0,000028$ & $-0,000029$ & $-0,000016$ & 50.05 & 43,63 \\
\hline & 3 & $-0,000042$ & $-0,000049$ & $-0,000074$ & $-0,000067$ & $-0,000071$ & $-0,000045$ & 126,24 & 102,25 \\
\hline & 4 & $-0,000093$ & $-0,000104$ & $-0,000144$ & $-0,000133$ & $-0,000138$ & $-0,000098$ & 252,88 & 202,75 \\
\hline & 5 & $-0,000144$ & $-0,000160$ & $-0,000218$ & $-0,000202$ & $-0,000210$ & $-0,000152$ & 381,87 & 305,49 \\
\hline & 6 & $-0,000191$ & $-0,000214$ & $-0,000298$ & $-0,000275$ & $-0,000287$ & $-0,000203$ & 506.92 & 403,62 \\
\hline & 7 & $-0,000229$ & $-0,000260$ & $-0,000373$ & $-0,000342$ & $-0,000357$ & $-0,000244$ & 613,47 & 502,37 \\
\hline & 8 & $-0,000251$ & $-0,000284$ & $-0,000406$ & $-0,000373$ & $-0,000390$ & $-0,000268$ & 665,38 & 545,49 \\
\hline & 9 & $-0,000262$ & $-0,000297$ & $-0,000422$ & $-0,000388$ & $-0,000405$ & $-0,000279$ & 690,52 & 566,87 \\
\hline & 10 & $-0,000282$ & $-0,000318$ & $-0,000449$ & $-0,000413$ & $-0,000431$ & $-0,000300$ & 732.72 & 602.00 \\
\hline
\end{tabular}


Analisando-se os dados da tab.D2 observa-se que, para o modelo PSC I, os valores teóricos das forças resistentes se distanciam bastante dos valores experimentais; os valores esperados das forças são o dobro das cargas aplicadas. Para o modelo PSC II, os valores teóricos são em torno de $30 \%$ maiores que os experimentais, nas etapas iniciais de carregamento; para etapas próximas da ruptura, essa diferença aumenta para $46 \%$.

Para o modelo PSC IIa, a diferença entre os valores teóricos das forças e os experimentais foi muito pequena; para este caso, o modelo de cálculo de flexocompressão demonstrou ser bastante eficiente.

A diferença percentual entre os valores esperados e os obtidos do ensaio, para o modelo PSC III, ficou em torno de 17\%. Para o modelo PSC IIIa, essa diferença variou entre 20 e $23 \%$.

Era esperado que os painéis com nervuras tivessem um modo de ruptura por flexo-compressão, considerando-se uma pequena excentricidade acidental. Apesar de o ensaio ser de compressão centrada, é difícil colocar o dispositivo de carregamento exatamente centrado no painel. Como se pôde observar, com exceção do modelo PSC IIa, a maioria dos modelos romperam com valores bem menores que os valores esperados. Essa diferença entre valores teóricos e experimentais foi maior para o modelo PSC I, que não possuía nervura.

O dispositivo de aplicação da força por meio do macacos hidráulicos pode ser visto na fig.D3. A força era aplica diretamente em um perfil metálico tipo I. Entre o perfil e a superfície do painel, foi colocado um elemento de madeira de espessura de $7 \mathrm{~cm}$, para uniformizar melhor as tensões nessa região. Esperava-se que com esse dispositivo as perturbações das tensões no painel fossem minoradas na região próxima da aplicação da carga. O dispositivo não apresentou eficácia, sendo este o motivo principal de suspeita da ruptura precoce dos painéis, por esmagamento da argamassa nas regiões adjacentes das extremidades.

Nas extremidades superior e inferior do painel, não foram previstos elementos maciços da própria argamassa, para diminuir perturbações das tensões nessas regiões, conforme ilustra a fig.D17. O que existiam eram nervuras de espessura de $3,5 \mathrm{~cm}$, e parece que elas não contribuíram de forma significativa. 
A falta desses elementos de extremidade, para receber as cargas aplicadas e transmiti-las para as faces, provavelmente, pelo que foi investigado, foi o fator principal para ruptura precoce dos modelos, com cargas inferiores àquelas esperadas.

$\mathrm{Na}$ prática, esses elementos de extremidades vão sempre existir, seja representado pela fundação ou pela laje.

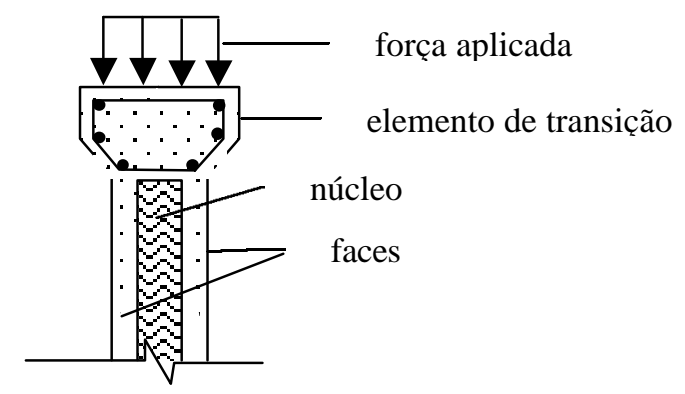

FIGURA D17 - ELEMENTO DE TRANSIÇÃO PARA RECEBIMENTO DAS CARGAS

Os ensaios de compressão centrada deveriam ser realizados novamente, mas infelizmente não puderam ser refeitos por uma questão de tempo, necessitando-se concluir o trabalho.

\section{CONSIDERAÇÕES A RESPEITO DO ENSAIO}

Analisando-se os elementos comprimidos sujeitos à flexo-compressão, as forças últimas obtidas nos ensaios não corresponderam, para nenhum dos modelos, ao esgotamento da capacidade última dos materiais (argamassa e aço). A falta de um elemento de transição nas extremidades dos painéis, para receber as forças aplicadas, prejudicou o andamento dos ensaios, ocorrendo ruína precoce dos elementos, caracterizando-se por esmagamento da argamassa na parte superior ou inferior do painel, de acordo com o modelo ensaiado.

Principalmente por causa dos problemas ocorridos nos ensaios, não se pôde avaliar se o modelo de cálculo, considerando-se a seção completamente composta solicitada a flexo-compressão, pode ser adotado para uma seção tipo sanduíche, com placas executadas por projeção da argamassa. Pelo andamento dos ensaios, comparando-se as forças teóricas com as experimentais, em especial as do modelo PSF IIa, é provável que o modelo adotado seja adequado para o tipo de elemento estudado, necessitando-se para isto refazer todos os ensaios, com as modificações mencionadas, para eliminar os problemas ocorridos. 


\section{REFERÊNCIAS}

ALLEN, H.G. (1969). Analysis and design of structural sandwich panels. Oxford, Pergamon.

AMERICAN CONCRETE INSTITUTE (1981). Application and use shotcrete. Detroit, ACI.

AMERICAN CONCRETE INSTITUTE (1994). ACI 506 R/90 - Guide to shotcrete. Detroit, ACI.

AMIN, P.E.; SALMON, D.C.; FOGANASI, J.G.; CULP, T.D.; TRADOS, M.K. (1991). State-of-the-art of precast concrete sandwich panels. PCI Journal, v.36, n.6, p.78-98, Nov.-Dec.

ASSOCIAÇÃO BRASILEIRA DE NORMAS TÉCNICAS (1982). NBR 6118 Projeto e execução de obras de concreto armado. Rio de Janeiro.

ASSOCIAÇÃO BRASILEIRA DE NORMAS TÉCNICAS (1992). NBR 6152 Materiais metálicos - Determinação das propriedades mecânicas à tração. Rio de Janeiro.

ASSOCIAÇÃO BRASILEIRA DE NORMAS TÉCNICAS (1982). NBR 7680 Extração, preparo, ensaio e análise de testemunhos de estruturas de concreto. Rio de Janeiro.

ASSOCIAÇÃO BRASILEIRA DE NORMAS TÉCNICAS (1983). NBR 7211 Agregado para concreto - especificações. Rio de Janeiro.

ASSOCIAÇÃO BRASILEIRA DE NORMAS TÉCNICAS (1989). NBR 7197 -

Projetos de estruturas de concreto protendido. Rio de Janeiro.

ASSOCIAÇÃO BRASILEIRA DE NORMAS TÉCNICAS (1992). NBR 11768 Aditivos para concreto de cimento Portland. Rio de Janeiro. 
ASSOCIAÇÃO BRASILEIRA DE NORMAS TÉCNICAS (1996). NBR 7215 Cimento Portland - Determinação de resistência à compressão. Rio de Janeiro.

BANSUlBUL, A.I.; SALEEM, M.; AL-SUlAIMANI, G.J. (1991). Flexural behavior of ferrocement sandwich panels. Cement \& Concrete Composites, v.13, p.21-28.

BUSH, T.D.; STINE, G.L. (1994). Flexural behavior of composite precast concrete sandwich panels with continuous truss connectors. PCI Journal, v.39, n.2, p.112-121, Mar.-Abr.

BUSH, T.D.; WU, Z. (1998). Flexural analysis of prestressed concrete sandwich panels with truss connectores. PCI Journal, v.43, n.5, p.76-86, Sep.-Oct.

COLLINS F.T. (1954). Precast concrete sandwich panels for tilt-up constructions. ACI Journal, v.26, n.2, p149-164.

CUNHA, R.D.A. (1991). Dosagem de microconcretos para elementos estruturais de pequena espessura. São Carlos. Dissertação (Mestrado) - Escola de Engenharia de São Carlos, Universidade de São Paulo.

EINEA, A.; SAlMON, D. C.; FOGARASI, G. J.;TADROS, M. K.; CULP, T. (1991). State-of-the-art of precast concrete sandwich panels. PCI Journal, v.36, n.6, p.78-98, Nov.-Dec.

EINEA, A.; SALMON, D.C.; TADROS, M.K.; CULP, T. (1994). A new structurally and thermally efficient precast sandwich panel system. PCI Journal, p.90-101, July.-Aug.

FIGUEIREDO, A.D. (1992). Concreto projetado: fatores intervenientes no controle da qualidade do processo. São Paulo. Dissertação (Mestrado) - Escola Politécnica, Universidade de São Paulo.

FIGUEIREDO, A.D. (1997). Parâmetros de controle e dosagem do concreto projetado com fibras de aço. São Paulo. Tese (Doutorado) - Escola Politécnica, Universidade de São Paulo. 
FONSECA, F.J.C. (1994). Projeto de painéis sanduíche de concreto pré-moldado. São Carlos. Dissertação (Mestrado) - Escola de Engenharia de São Carlos, Universidade de São Paulo.

FROSTIG, Y. (1993). High-order behavior of sandwich beams with flexible core and transverse diaphagms. Journal of Engineering Mechanics, v.119, n.5, p.955-972. May.

HANAI, J.B. (1981). Construções em argamassa armada: situação, perspectiva e pesquisa. São Carlos. Tese (Doutorado) - Escola de Engenharia de São Carlos, Universidade de São Paulo.

HANAI, J.B. (1992). Construções de argamassa armada: fundamentos tecnológicos para projeto e execução. São Paulo, Pini.

HANAI, J.B.; TAKEYA, T. (1994). Estudo do comportamento estrutural de painéis MONOLITE CABRINI na flexão simples. Relatório final, Laboratório de estruturas.

HARTSOCK, J.A.; CHONG, K.P. (1976). Analysis of sandwich panels with formed faces. Journal of the Structural Division, v.102, n. ST4, Apr.

HINTON, E; OWEN, D. R. J. (1984). Finite element software for plates and shells. Pineridge Press.

KOBLER, H.G. (1966). Dry-mix coarse aggregate shotcrete as underground support. In: AMERICAN CONCRETE INSTITUTE. Shotcreting. Detroit, ACI. p.33-58. (ACI SP-14)

KOSKI, J.A. (1993). Shotcrete homes chanllenge wood-frame construction. Aberdeen's Concrete Construction, v.38, n.11, Nov., p.798-802.

LEE, S.L.; MANSUR, M.A.; PARAMASIVAM, P.; ONG, K.C.G.; TAM, C.T. (1986). A study of sandwich wall panel. Journal of Ferrocement, v.16, n.3, p.295-313, July.

LIBÓRIO, J.B.L.; MELO, A.B. (1996). Proposta metodológica para dosagem das "argamassas estruturais" utilizando cura térmica (vapor) sob pressão atmosférica. In: REUNIÃO DO IBRACON, 38., Ribeirão Preto. 19-23 ago. 1996. Anais. São Paulo, IBRACON. v.2, p.551-564. 
MACHADO JR., E.F. (1991). Casas populares pré-moldadas em argamassa armada: procura de uma solução econômica e confortável. São Carlos. Tese (Doutorado) - Escola de Engenharia de São Carlos, USP.

METHA, P.K.; MONTEIRO, P.J.M. (1994). Concreto: estrutura, propriedades e materiais. São Paulo, Pini. 573p.

NANNI, A.; CHANG, W.F. (1986). Ferrocement sandwich panel under bending and edge-wise compression. Journal of Ferrocement, v.16, n.2, p.129-140, 1986.

NEVILLE, A.M. (1982). Propriedades do concreto. Trad. Salvador F. Giamnuso. São Paulo, Pini.

PCI COMMITTEE REPORT (1997). State-of-the-art of precast/prestressed sandwich wall panels. PCI Journal, p.32-49, May-June.

PCI COMMITTEE REPORT (1997) State-of-the-art of precast/prestressed sandwich wall panels. PCI Journal, p.92-134, Mar.-Abr.

PEARSON, R.I. (1989). Residencial construction with composite panels. Concrete International: Design and Construction, v.11, n.7, p.40-41, July.

PFEIFER D.W.; HANSON, J.A. (1965). Precast concrete wall panel: flexural stiffness of sandwich panels. PCA bulletin D99, Portland Cement Association. Skokie, p.67-68.

PICKARD, S.S. (1990). Welded wire sandwich panels: An alternative to woodframe construction. Concrete Construction, v.35, n.4, p.363-366, Apr.

PLANTEMA, F. (1966). The bending and buckling of sandwich beams, plates and shells. London, John Wiley \& Sons.

PRECAST/PRESTRESSED INSTITUTE (1992). PCI design handbook. 4.ed. Chicago.

PRUDÊNCIO JR., L.R. (1993). Contribuição à dosagem do concreto projetado. São Paulo. Tese (Doutorado) - Escola Politécnica, Universidade de São Paulo. ROBERTS, S.B. (1951). Sandwich wall precast for pulp mill. Engineering News Record, v.148, n.8, p.32-34. 
SALMON, D.C.; EINEA, A. (1996). Partially composite sandwich panel deflections. Journal of Structural Engineering. v.121, n.4, p.778-783, Apr.

SHEPPARD, D.A.; PHILLIPS, W.R. (1989). Plant cast precast and prestressed concrete. Califórnia, McGraw-Hill. 789p.

SPOSTO, R.M. (1995). Painéis de argamassa armada compostos com isolantes térmicos para vedos de habitação de baixo custo em São Paulo. São Paulo. Tese (Doutorado) - Faculdade de Arquitetura e Urbanismo, Universidade de São Paulo.

TÉCHNE (1999), Revista de Tecnologia da Construção, n.39. p30-34, mar/abr, PINI. TEXEIRA, P.W.G.N. (1999). Projeto e execução de coberturas em casca de concreto com forma de membrana pênsil invertida e seção tipo sanduíche. São Carlos. Tese (Doutorado) - Escola de Engenharia de São Carlos, Universidade de São Paulo.

WARNER, J. (1995). Understanding shotcrete: its application. Concrete International: Design and Construction, p.37-39, June.

\section{BIBLIOGRAFIA COMPLEMENTAR}

ACHCAR, J.A.; RODRIGUES, J. (1992). Introdução à estatística para ciências e tecnologia. São Carlos, Publicação EESC-USP.

AGOPYAN, V.A. (1991). Materiais reforçados com fibras para construção civil nos países em desenvolvimento: o uso de fibras vegetais. São Paulo. 204p. Tese (Livre-docência) - Escola Politécnica, Universidade de São Paulo.

ALI, M.M.; NAPIER, T.R. (1989). Evaluation technique for concrete building systems. Concrete International: Design and Construction, v.11, n.7, p.33-39, July.

AMIN, P.E.; SALMON, D.C.; CULP, T.D.; TRADOS, M.K. (1994). A new structurally and thermally efficient precast sandwich panel system. PCI Journal, p.90-101, July-Aug. 
ASSOCIAÇÃO BRASILEIRA DE NORMAS TÉCNICAS (1980). NBR 5739 Ensaios de compressão de corpos de prova cilíndricos de concreto. Rio de Janeiro.

ASSOCIAÇÃO BRASILEIRA DE NORMAS TÉCNICAS (1982). NBR 7251 Agregado em estado solto. Determinação da massa unitária. Rio de Janeiro.

ASSOCIAÇÃO BRASILEIRA DE NORMAS TÉCNICAS (1984). NBR 5738 -

Moldagem e cura de corpos-de-prova de concreto, cilíndricos ou prismáticos. Rio de Janeiro.

ASSOCIAÇÃO BRASILEIRA DE NORMAS TÉCNICAS (1984). NBR 8490 Argamassas endurecidas para alvenaria estrutural - retração por secagem. Rio de Janeiro.

ASSOCIAÇÃO BRASILEIRA DE NORMAS TÉCNICAS (1984). NBR 8522 Concreto - determinação do módulo de deformação estática e diagrama tensão-deformação. Rio de Janeiro.

ASSOCIAÇÃO BRASILEIRA DE NORMAS TÉCNICAS (1986). NBR 9606 Concreto - determinação da consistência pelo espalhamento do tronco de cone. Rio de Janeiro.

ASSOCIAÇÃO BRASILEIRA DE NORMAS TÉCNICAS (1987). NBR 7217 Agregado. Determinação da composição granulométrica. Rio de Janeiro.

ASSOCIAÇÃO BRASILEIRA DE NORMAS TÉCNICAS (1987). NBR 9775 Agregado. Determinação da umidade superficial em agregados miúdos por meio do frasco de Chapman. Rio de Janeiro.

ASSOCIAÇÃO BRASILEIRA DE NORMAS TÉCNICAS (1994). NBR 13070 Moldagem de placas para ensaio de argamassa e concreto projetados. Rio de Janeiro.

ASSOCIAÇÃO BRASILEIRA DE NORMAS TÉCNICAS (1995). NBR 13354 Concreto projetado - determinação do índice de reflexão em placas. Rio de Janeiro. 
BALLARIN, A.W. (1989). Propriedades mecânicas da argamassa armada com telas soldadas. São Carlos. Dissertação (Mestrado) - Escola de Engenharia de São Carlos, Universidade de São Paulo.

BALLISTA, L.P.Z. Estudo de Argamassas e microconcretos projetados. In: VI CONGRESSO DE INICIAÇÃO CIENTÍFICA DA USP, 6., São Carlos, out 1998. Anais. São Paulo, USP. v.2, p.35.

BERTINI, A.A. (1995). Análise do comportamento à flexão de painéis sanduíche com faces de argamassa armada e núcleo de espuma rígida de poliuretano derivado de óleo de mamona. São Carlos. Dissertação (Mestrado) - Escola de Engenharia de São Carlos, Universidade de São Paulo.

BERTINI, A.A. (1996) Concreto projetado: definição, propriedades e aplicações. São Carlos, EESC-USP, Departamento de Engenharia de Estruturas. /Seminário apresentado à disciplina "Fundamentos de Concreto II"/

BERTINI, A.A.; MACHADO JR., E.F. (1994). O painel sanduíche nas obras civis: uma revisão do emprego na construção de habitações. In: CONGRESSO DE ENGENHARIA CIVIL DA UNIVERSIDADE FEDERAL DE JUIZ DE FORA, 1., Juiz de Fora, ago. 1994. Anais. Juiz de Fora, FE-UFJF. v.2, p.77-88.

BERTINI, A.A.; MACHADO JR., E.F. (1995). Investigação do comportamento à flexão de painéis sanduíche de faces de argamassa armada e núcleo de poliuretano. In: JORNADAS SUDAMERICANAS DE INGENIERÍA ESTRUCTURAL, 27., Tucumán, Argentina, 18-22 septiembre, 1995. Memórias. Tucumán, ASAIE / Laboratório de Estructuras-FCET-UNT. v.1, p.119-130.

BETOMAQ INDUSTRIAL LTDA (1997). Argamassa bombeável. São Paulo. (catálogo técnico).

CABRINI MONOLITE. Sistema de construção anti-sísmico e isolante termoacústico. Idaiatuba-SP. (catálogo técnico).

CHANG, W.F. (1983). The prototype factory-built ferrocement home. Journal of Ferrocement, v.13, n.1, p.73-76, Jan. 
EL DEBS, M.K. (1991) Contribuição ao emprego de pré-moldados de concreto em infra-estrutura urbana e em estradas. São Carlos. Tese (Livre-docência) Escola de Engenharia de São Carlos, Universidade de São Paulo.

FERREIRA, O.P.; SILVA, I.J. (1995). Argamassa de cimento com adição de fibras de polipropileno. In: SIMPÓSIO BRASILEIRO DE TECNOLOGIA DE ARGAMASSAS, 1, Goiânia, 16-17 ago. 1995. Anais. Goiânia, Escola de Engenharia Civil - UFG / ANTAC. p.33-42.

GIONGO, J.S. (1990). Argamassa armada: dimensionamento de perfis, submetidos à flexão. Fundamentos e experimentação. São Carlos. Tese (Doutorado) - Escola de Engenharia de São Carlos, Universidade de São Paulo.

HA, K.H. (1990). Finite elements analysis of sandwich plates: an overview. Computers \& Structures, v.37, n.4, p.397-403.

HURD, M.K. (1989). Welded wire sandwich panels shotcreted. Concrete Construction, v.21, n.5, p.861-868.

MARTINELLI, D.A.O. (1983) Sobre a ruína das ligações laje-pilar nos cantos de lajes-cogumelo. São Carlos, Publicação EESC-USP 075/83.

OLIVEIRA, C.T.A.; AGOPYAN, V. (1996). Desenvolvimento de um painel de gesso reforçado com fibra de vidro para vedação vertical interna. São Paulo, EPUSP. (BT/PCC/164).

SHENDY, M.E. (1991). Comparative study of LECA concrete sandwich beams with and without core reinforcement. Cement \& Concrete Composites, v.13, n.2, p.143-149.

SIFRE, P.; HARRISON, D. (1996). Gate house for Johnson. Civil Engineering, v.66, n.2, p. 44-45, Feb.

TAKEYA, T. (1988). Introdução à análise experimental de estruturas. São Carlos, Publicação EESC-USP. 